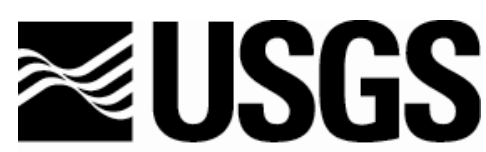

science for a changing world

Prepared in cooperation with the NEVADA OPERATIONS OFFICE of the U.S. DEPARTMENT OF ENERGY, under Interagency Agreement, DE-AI52-01NV13944

\title{
Analysis of Ground-Water Levels and Associated Trends in Yucca Flat, Nevada Test Site, Nye County, Nevada, 1951-2003
}

Scientific Investigations Report 2005-5175 
(Back of Cover) 


\section{Analysis of Ground-Water Levels and Associated Trends in Yucca Flat, Nevada Test Site, Nye County, Nevada, 1951-2003}

By Joseph M. Fenelon

Prepared in cooperation with the

NEVADA OPERATIONS OFFICE of the U.S. DEPARTMENT OF ENERGY,

under Interagency Agreement, DE-AI52-01NV13944

SCIENTIFIC INVESTIGATIONS REPORT 2005-5175

U.S. Department of the Interior

U.S. Geological Survey 


\section{U.S. Department of the Interior \\ Gale A. Norton, Secretary \\ U.S. Geological Survey \\ P. Patrick Leahy, Acting Director}

\section{U.S. Geological Survey, Carson City, Nevada, 2005}

For more information about the USGS and its products:

U.S. Geological Survey, Information Services

Box 25286, Denver Federal Center

Denver, C0 80225

Telephone: 1-888-ASK-USGS

World Wide Web: http://www.usgs.gov/

Any use of trade, product, or firm names in this publication is for descriptive purposes only and does not imply endorsement by the U.S. Government.

Although this report is in the public domain, permission must be secured from the individual copyright owners to reproduce any copyrighted materials contained within this report.

Suggested citation:

Fenelon, J.M., 2005, Analysis of ground-water levels and associated trends in Yucca Flat, Nevada Test Site, Nye County, Nevada, 1951-2003: U.S. Geological Survey Scientific Investigations Report 2005-5175, 87 p., at URL: <http://pubs.water.usgs.gov/sir2005-5175>. 


\section{Contents}

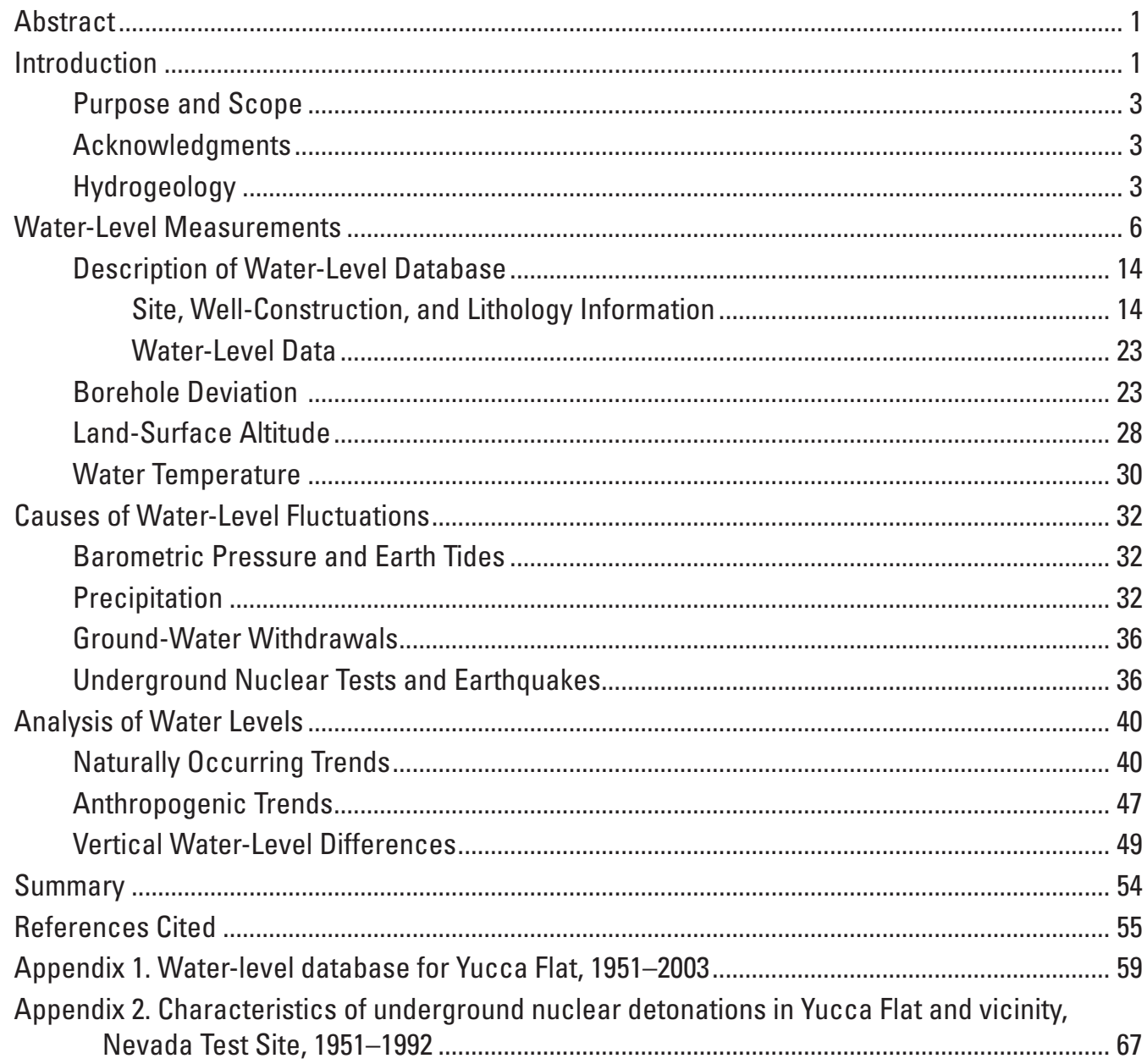

\section{Figures}

Figure 1. Map showing regional features and ground-water flow in the area near Yucca Flat, Nevada Test Site.

Figure 2. Map showing location of boreholes with water-level measurements and boreholes having ground-water withdrawals in Yucca Flat, Nevada Test Site, 1951-2003.............. 4

Figure 3. Map showing distribution of hydrogeologic units and major faults at the water table in Yucca Flat, Nevada Test Site...................................................................................... 5

Figure 4. Graphs showing daily mean water levels from wells in Yucca Flat with continuous water levels measured by the U.S. Geological Survey.

Figure 5. Diagram showing relations among Microsoft ${ }^{\circledR}$ Access files in the Yucca Flat water-level database.

Figure 6. Diagram example of water-level output from Microsoft $\circledast$ Excel workbook. 
Figure 7. Hydrograph of well TW-7 showing (1) example of general and detailed condition attributes that were assigned to water levels, and (2) relation between water levels and nearby underground nuclear tests

Figure 8. Graphs showing short-term response of water levels in well U-3cn 5 to barometric pressure and Earth tides, October 1995

Figure 9. Graphs showing annual precipitation and cumulative departure from mean precipitation at index sites in the Spring Mountains, Rainier Mesa, and Pahranagat Valley, 1964-2003

Figure 10. Graphs showing ground-water withdrawals by well in Yucca Flat, 1950-2003............ 37

Figure 11. Graphs showing total annual withdrawals and withdrawals by aquifer type in Yucca Flat, 1950-2003.

Figure 12. Map showing distribution of underground nuclear tests in the Yucca Flat area, Nevada Test Site

Figure 13. Graphs showing relation among water levels with naturally occurring trends from selected wells in carbonate-rock aquifers, Yucca Flat area, 1994-2003.

Figure 14. Graphs showing relation among water levels with naturally occurring trends from selected wells in volcanic tuffs, Yucca Flat area, 1994-2003. 44

Figure 15. Graphs showing relation among water levels with naturally occurring trends from selected wells in the Eleana confining unit, Yucca Flat area, 1994-2003.

Figure 16. Graphs showing relation between trends in precipitation and steady-state water levels from selected wells in the Yucca Flat area, 1980-2003.

Figure 17. Graphs showing relation between ground-water withdrawals and water levels from selected wells affected by withdrawals in Yucca Flat, 1952-2003.

Figure 18. Graphs showing relation among trends in water levels from selected wells likely affected by underground nuclear tests, Yucca Flat.

Figure 19. Map showing vertical water-level differences, direction of vertical groundwater gradients, and location of underground nuclear tests in the Yucca Flat area, Nevada Test Site.

\section{Tables}

Table 1. Characteristics of wells with at least one water-level measurement through 2003 in the Yucca Flat area, Nevada Test Site.

Table 2. Summary of water-level measurements from wells in the Yucca Flat area, Nevada Test Site.

Table 3. Description of general- and detailed-condition attributes assigned to water levels in Yucca Flat.

Table 4. Water-level corrections for borehole deviations in selected boreholes in Yucca Flat.... 27

Table 5. Survey estimates of land-surface and measuring-point altitudes for water-level monitoring wells in Yucca Flat.

Table 6. Approximate effects of temperature on hydraulic-head estimates for selected wells in the Yucca Flat area

Table 7. Information for precipitation sites used to create precipitation indices for Yucca Flat .. 34

Table 8. Analysis of water-level trends, using the Mann-Kendall test, for selected wells in the Yucca Flat area.

Table 9. Open-interval and water-level data for selected wells used to analyze vertical water-level differences in the Yucca Flat area.

Table 10. Description of Microsoft $®$ Access database for Yucca Flat water-level measurements. 
CONVERSION FACTORS AND VERTICAL DATUM

\begin{tabular}{|c|c|c|}
\hline Multiply & By & To obtain \\
\hline \multicolumn{3}{|c|}{ Length } \\
\hline inch (in.) & 2.54 & centimeter $(\mathrm{cm})$ \\
\hline foot $(\mathrm{ft})$ & 0.3048 & meter $(\mathrm{m})$ \\
\hline mile (mi) & 1.609 & kilometer (km) \\
\hline \multicolumn{3}{|c|}{ Volume } \\
\hline barrel (42 gal) & 159.0 & liter (L) \\
\hline gallon (gal) & 3.785 & liter $(\mathrm{L})$ \\
\hline million gallons (Mgal) & 3,785 & cubic meter $\left(\mathrm{m}^{3}\right)$ \\
\hline million gallons (Mgal) & 3.069 & acre-foot (acre-ft) \\
\hline \multicolumn{3}{|c|}{ Transmissivity } \\
\hline foot squared per day $\left(\mathrm{ft}^{2} / \mathrm{d}\right)$ & 0.09290 & meter squared per day $\left(\mathrm{m}^{2} / \mathrm{d}\right)$ \\
\hline \multicolumn{3}{|c|}{ Energy } \\
\hline kiloton & $4.184 \times 10^{12}$ & joules $(\mathrm{J})$ \\
\hline \multicolumn{3}{|c|}{ Pressure } \\
\hline pound per square inch $\left(\mathrm{lb} / \mathrm{in}^{2}\right)$ & 6.895 & kilopascal (kPa) \\
\hline \multicolumn{3}{|c|}{ Specific capacity } \\
\hline $\begin{array}{l}\text { gallons per minute per foot of } \\
\text { drawdown (gal/min per foot) }\end{array}$ & 17.88 & $\begin{array}{l}\text { cubic meter per day per meter of } \\
\text { drawdown }\left(\mathrm{m}^{2} / \mathrm{d}\right)\end{array}$ \\
\hline \multicolumn{3}{|c|}{ Flow rate } \\
\hline foot per day (ft/d) & 0.3048 & meter per day $(\mathrm{m} / \mathrm{d})$ \\
\hline foot per year (ft/yr) & 0.3048 & meter per year $(\mathrm{m} / \mathrm{yr})$ \\
\hline inch per year (in/yr) & 25.4 & millimeter per year (mm/yr) \\
\hline \multicolumn{3}{|c|}{ Volumetric rate } \\
\hline acre-foot per year (acre-ft/yr) & 1,233 & cubic meter per year $\mathrm{m}^{3} / \mathrm{yr}$ ) \\
\hline gallon per minute (gal/min) & 0.06309 & liter per second per meter $(\mathrm{L} / \mathrm{s})$ \\
\hline
\end{tabular}

Sea level: In this report, "sea level" refers to the National Geodetic Vertical Datum of 1929 (NGVD of 1929, formerly called "Sea-level Datum of 1929"), which is derived from a general adjustment of the first-order leveling networks of the United States and Canada.

Datum: Horizontal coordinate information is referenced to the North American Datum of 1983 (NAD83) unless otherwise stated.

Temperature: Degrees Celsius $\left({ }^{\circ} \mathrm{C}\right)$ can be converted to degrees Fahrenheit $\left({ }^{\circ} \mathrm{F}\right)$ by using the formula ${ }^{\circ} \mathrm{F}=\left(1.8 \mathrm{x}{ }^{\circ} \mathrm{C}\right)+32$.

Transmissivity: The standard unit for transmissivity is cubic foot per day per square foot times foot of aquifer thickness $\left[\left(\mathrm{ft}^{3} / \mathrm{d}\right) / \mathrm{ft}^{2}\right] \mathrm{ft}$. In this report, the mathematically reduced form, foot squared per day $\left(\mathrm{ft}^{2} / \mathrm{d}\right)$, is used for convenience. 


\title{
Analysis of Ground-Water Levels and Associated Trends in Yucca Flat, Nevada Test Site, Nye County, Nevada, 1951-2003
}

\author{
By Joseph M. Fenelon
}

\section{Abstract}

Almost 4,000 water-level measurements in 216 wells in the Yucca Flat area from 1951 to 2003 were quality assured and analyzed. An interpretative database was developed that describes water-level conditions for each water level measured in Yucca Flat. Multiple attributes were assigned to each waterlevel measurement in the database to describe the hydrologic conditions at the time of measurement. General quality, temporal variability, regional significance, and hydrologic conditions are attributed for each water-level measurement. The database also includes narratives that discuss the waterlevel history of each well.

Water levels in 34 wells were analyzed for variability and for statistically significant trends. An attempt was made to identify the cause of many of the water-level fluctuations or trends. Potential causes include equilibration following well construction or development, pumping in the monitoring well, withdrawals from a nearby supply well, recharge from precipitation, earthquakes, underground nuclear tests, land subsidence, barometric pressure, and Earth tides.

Some of the naturally occurring fluctuations in water levels may result from variations in recharge. The magnitude of the overall water-level change for these fluctuations generally is less than 2 feet. Long-term steady-state hydrographs for most of the wells open to carbonate rock have a very similar pattern. Carbonate-rock wells without the characteristic pattern are directly west of the Yucca and Topgallant faults in the southwestern part of Yucca Flat. Longterm steady-state hydrographs from wells open to volcanic tuffs or the Eleana confining unit have a distinctly different pattern from the general water-level pattern of the carbonaterock aquifers.

Anthropogenic water-level fluctuations were caused primarily by water withdrawals and nuclear testing. Nuclear tests affected water levels in many wells. Trends in these wells are attributed to test-cavity infilling or the effects of depressurization following nuclear testing. The magnitude of the overall water-level change for wells with anthropogenic trends can be large, ranging from several feet to hundreds of feet.
Vertical water-level differences at 27 sites in Yucca Flat with multiple open intervals were compared. Large vertical differences were noted in volcanic rocks and in boreholes where water levels were affected by nuclear tests. Small vertical differences were noted within the carbonate-rock and valley-fill aquifers. Vertical hydraulic gradients generally are downward in volcanic rocks and from pre-Tertiary clastic rocks toward volcanic- or carbonate-rock units.

\section{Introduction}

Yucca Flat is in the northeastern part of the Nevada Test Site (NTS) in Nye County, southern Nevada (fig. 1). During the period 1951-1992, 659 underground nuclear tests were detonated in Yucca Flat as well as 3 to the north of Yucca Flat (U.S. Department of Energy, 2000); 138 of these tests were considered certain or probable of introducing radionuclide contaminants into the ground water (Laczniak and others, 1996, table 4).

The U.S. Department of Energy (DOE), National Nuclear Security Administration, Nevada Site Office, under its Environmental Restoration Program, has a long-term program to investigate and remediate radionuclide contaminants generated on the NTS. As part of the program, DOE is evaluating the risk that these contaminants pose to the public. To accomplish this objective, a reasonable conceptual model of the ground-water flow system must be constructed. A necessary part of developing a model of the flow system is to compile and analyze available ground-water levels. This report is the third in a series of studies by the U.S. Geological Survey (USGS), in cooperation with DOE, to analyze and quality assure historic water-level measurements in areas of testing on the NTS (Fenelon, 2000; Bright and others, 2001).

As part of the water-level analysis in Yucca Flat, all water-level measurements need to be quality assured for accuracy and reliability. Additionally, the hydrologic conditions at the time of each water-level measurement must be determined. For example, determining whether an abrupt water-level rise 


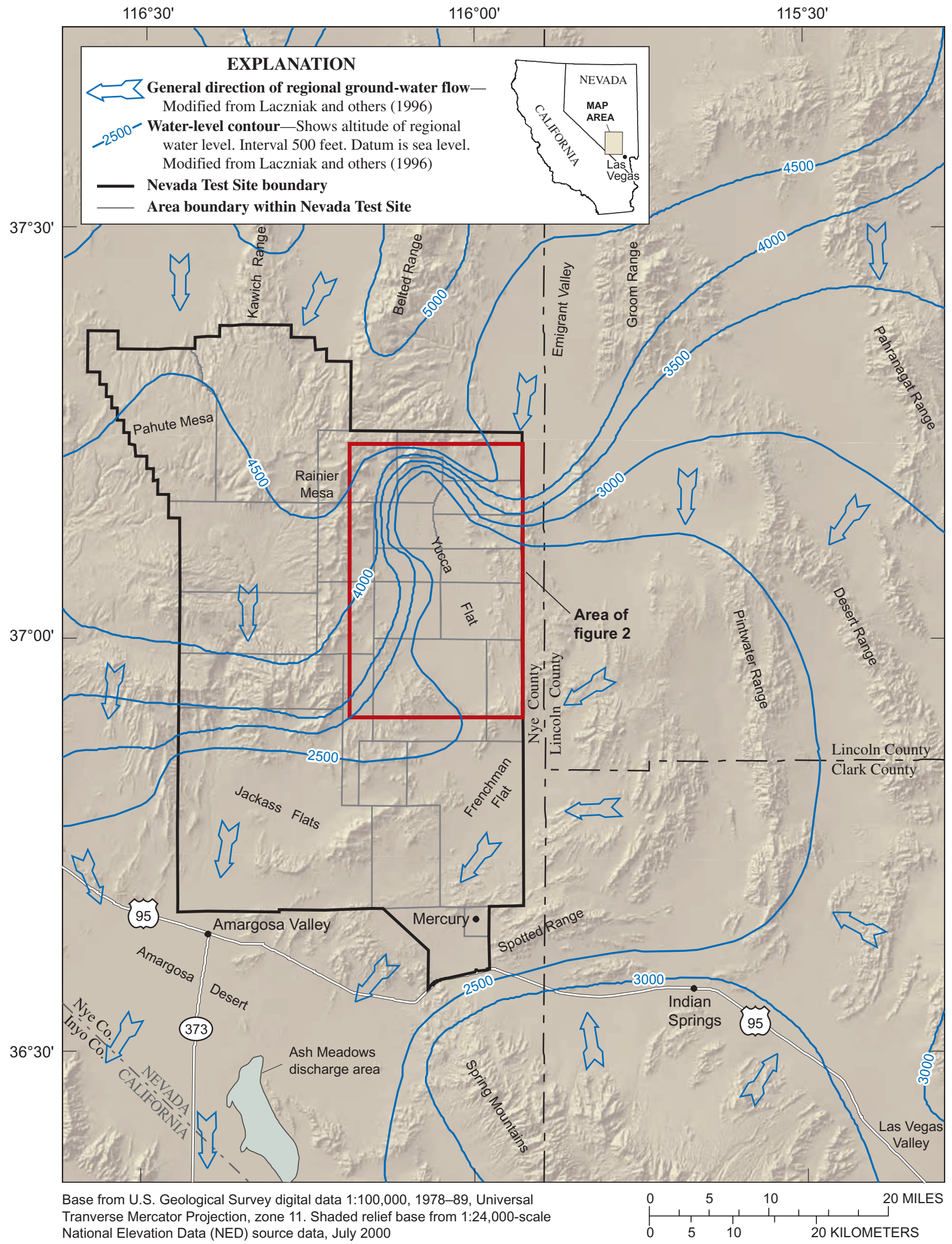

Figure 1. Map showing regional features and ground-water flow in the area near Yucca Flat, Nevada Test Site. 
was caused by a well slug test or by a nearby nuclear test is essential for correctly interpreting the water level. Finally, an analysis of the fluctuations or trends in ground-water levels is needed to identify long-term patterns and changes in water levels. Determining the causes of these trends can help identify what factors influence the flow system.

\section{Purpose and Scope}

This report documents the analysis of almost 4,000 water levels measured in 216 wells in Yucca Flat and vicinity from 1951 to 2003. As part of the analysis, a systematic qualityassurance review of the USGS National Water Information System (NWIS) database was done to remove or correct erroneous water-level data, remove duplicate sites, and add missing water-level measurements. Additionally, ancillary data necessary for computing hydraulic heads in wells were compiled. These data include well-completion records, borehole deviations, measuring points, and water temperatures, as well as information on lithologic units contributing water to the well. Reported ground-water withdrawals within the study area and precipitation data from major recharge areas near the Spring Mountains, Rainier Mesa, and Pahranagat Valley also were compiled.

An interpretive Microsoft ${ }^{\circledR}$ Access database of Yucca Flat water-level measurements was constructed that consists of several components. First, each water-level measurement was assigned multiple attributes to describe the hydrologic condition at the time of measurement. Second, each well hydrograph has a written narrative, which consists of comments or explanations about the well or about one or more measured water levels in the well. Third, water-level and site information from the NWIS database were merged into the Access water-level database to provide a comprehensive database of water-level measurements in Yucca Flat.

Water levels in wells with sufficient long-term data were analyzed for variability and for significant trends. Trends were analyzed statistically to detect significant upward or downward changes and graphically to compare trends among wells. An attempt was made to identify the cause of many of the waterlevel fluctuations or trends. Potential causes include equilibration following well construction or development, pumping or hydraulic testing in the monitoring well, withdrawals from a nearby supply well, recharge from precipitation, earthquakes, underground nuclear tests, land subsidence, barometric pressure, and Earth tides.

\section{Acknowledgments}

This study was prepared in cooperation with the U.S. Department of Energy under Interagency Agreement DEAI52-01NV13944. Thanks to the following individuals who provided data or information for the report: Desireé Brantley (Nevada Division of Water Resources) provided some of the precipitation data used in this report; David Wood (USGS) compiled most of the borehole lithologic descriptions that are provided in the water-level database; and Richard Remington and Scot Ellison (Bechtel Nevada) provided historic survey data of land-surface altitudes for wells in Yucca Flat. Special thanks to Randell Laczniak (USGS) for general guidance in the analysis and interpretation of data.

\section{Hydrogeology}

Yucca Flat is a topographically closed drainage basin that ranges from about 3,920 ft above sea level in Yucca Lake to about 4,500 $\mathrm{ft}$ above sea level on the perimeters of the basin floor. Yucca Flat is surrounded by CP Hills to the south, Halfpint Range to the east, Rhyolite Hills and Quartzite Ridge to the north, and Eleana Range to the west (fig. 2). These adjacent highlands typically reach altitudes of 5,000-7,000 ft above sea level.

Hydrogeologic units in Yucca Flat were defined by Laczniak and others (1996, table 2; pl. 3). They include the quartzite confining unit, lower carbonate-rock aquifer, Eleana confining unit, upper carbonate-rock aquifer, granite, tuff confining unit, welded-tuff aquifer, and valley-fill aquifer. The distribution of these units at the water table is shown in figure 3. Interpretations from recent (post-1994) geologic and geophysical investigations in Yucca Flat are not incorporated into this map.

The quartzite confining unit is composed of Cambrian and Eocambrian quartzite, siltstone and shale. Minor intrusions of Cretaceous granite on the north side of Yucca Flat also are grouped with the quartzite confining unit. The confining unit defines the lower boundary of the flow system and is exposed at the water table in northeastern Yucca Flat (fig. 3). The unit is believed to restrict the southerly flow of ground water on the northern edge of Yucca Flat, as evidenced by a steep ground-water gradient in that area (fig. 1; Winograd and Thordarson, 1975, p. 63-66).

The principal regional aquifer in Yucca Flat is the lower carbonate-rock aquifer. It consists of dolomite and limestone of Cambrian through Devonian age. The lower carbonate-rock aquifer predominates in the eastern part of Yucca Flat (fig. 3 ). In this area, water-level altitudes are about $2,500 \mathrm{ft}$ or less above sea level and ground-water gradients are small (fig. 1).

The Eleana confining unit underlies the west side of Yucca Flat (fig. 3). The unit consists of Devonian through Pennsylvanian siliceous siltstone (argillite), shale, conglomerate, and sandstone of the Eleana Formation and Chainman Shale. Steep ground-water gradients occur on the west side of Yucca Flat (fig. 1), where the confining unit restricts the movement of ground water.

The upper carbonate-rock aquifer, on the west side of Yucca Flat, is separated from the lower carbonate-rock aquifer by the Eleana confining unit. The upper carbonate-rock aquifer consists of Pennsylvanian Tippipah Limestone and Cambrian through Devonian carbonate rocks that have been thrust faulted over the Eleana confining unit. The upper carbonate- 


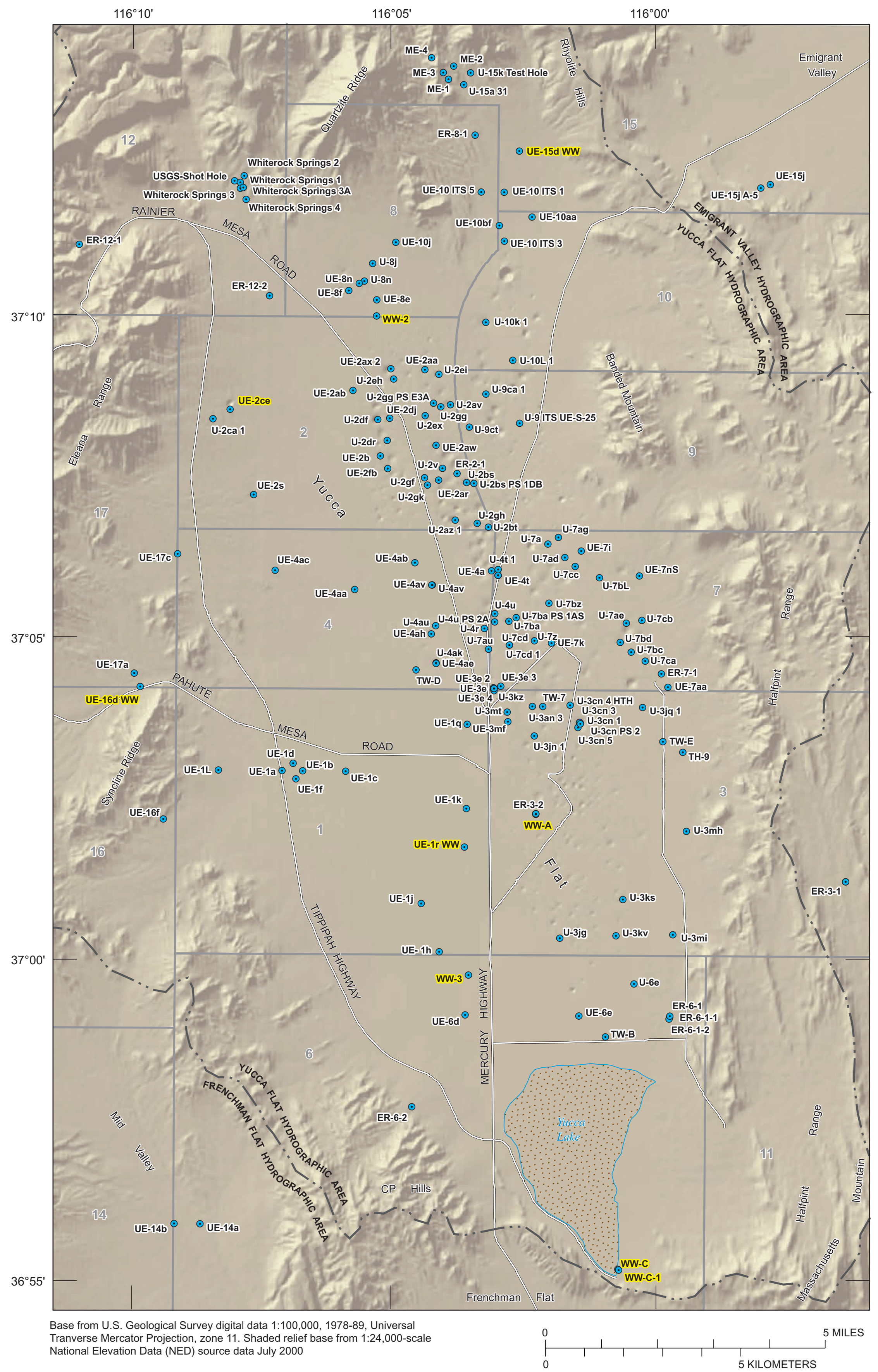

EXPLANATION

\author{
11 Area number and boundary within Nevada Test Site \\ ER-6-2 ${ }^{\odot}$ Borehole with water-level data and name- \\ Yellow highlight indicates borehole with ground-water withdrawal
}




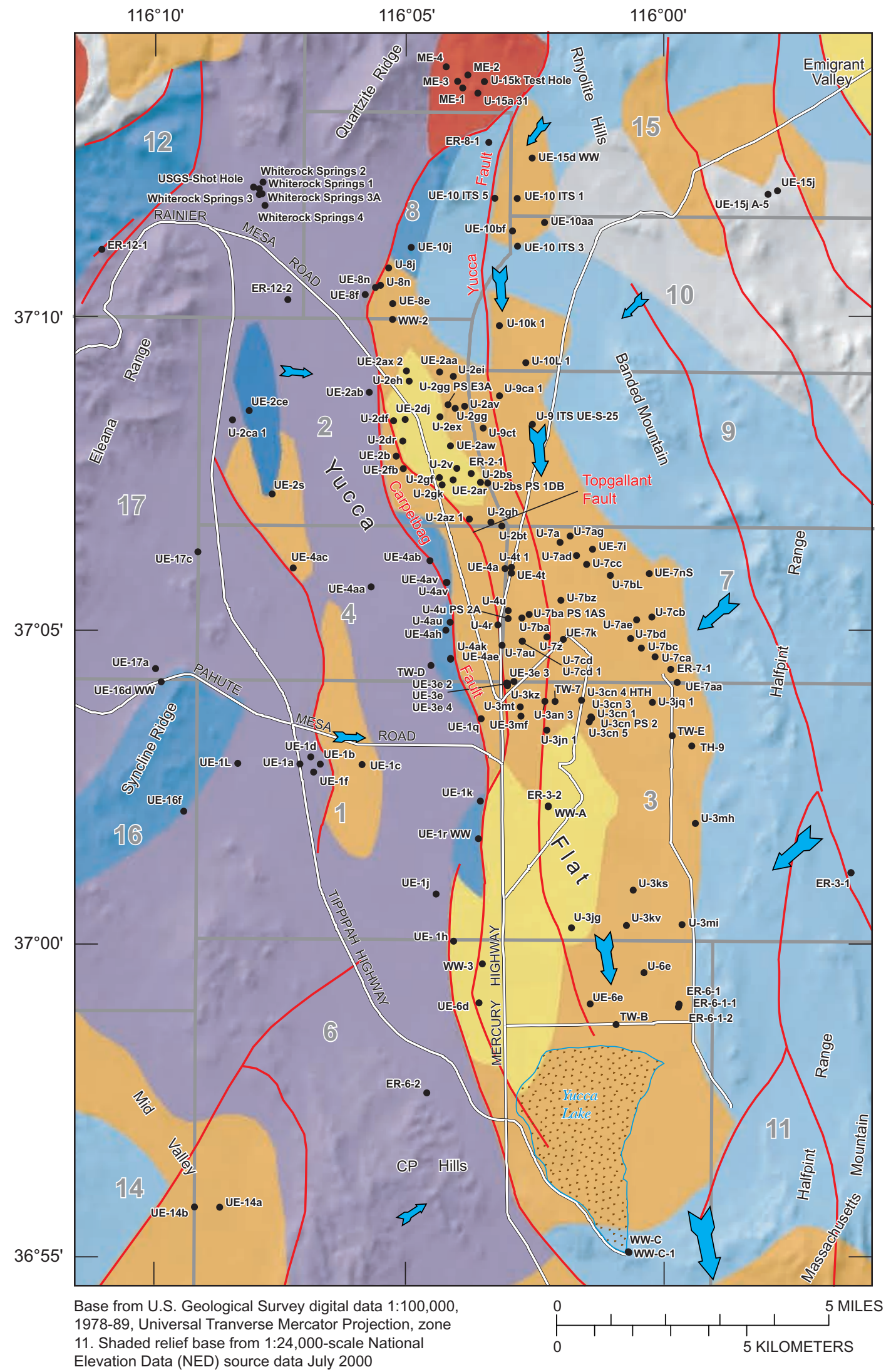

\section{EXPLANATION}

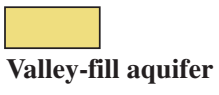

\section{Welded-tuff aquifer}

and tuff confining unit
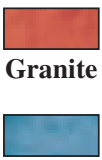

Upper carbonate-rock aquifer

Eleana confining unit

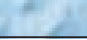 \\ Lower carbonate-rock aquifer}

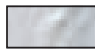

Quartzite confining unit

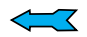

General direction of ground-water flowSize of arrow indicates relative volume of flow

11

Area number and boundary within Nevada Test Site

Fault-Approximate location of subsurface trace at water table

- ER- 3-1

Borehole with water-level data

Figure 3. Map showing distribution of hydrogeologic units and major faults at the water table in Yucca Flat, Nevada Test Site. Modified from Laczniak and others, 1996, plate 3. 
rock aquifer is limited in extent but may be locally important to flow transport.

Tertiary volcanic rocks and valley-fill alluvium are basin-filling deposits in Yucca Flat that overlie the pre-Tertiary rocks discussed above. Most of the underground nuclear tests in Yucca Flat occurred in these units. The volcanic rocks, deposited as tuffs from volcanoes to the west and northwest, are present at the water table in the eastern half of Yucca Flat (fig. 3). The lower sequence of volcanic rocks forms a tuff confining unit. It consists of bedded and reworked, nonwelded, commonly zeolitized tuffs. The tuff confining unit ranges in thickness from 0 to about $1,800 \mathrm{ft}$; saturated thickness can exceed 1,000 ft. The upper sequence of volcanic units forms a welded-tuff aquifer that is saturated only to a limited extent at the water table. Much of the alluvium in Yucca Flat is unsaturated. Where saturated in the deepest parts of the fault-controlled depressions in central Yucca Flat, the alluvium forms valley-fill aquifers (fig. 3). The alluvium consists of variably cemented, moderately sorted, gravel and sand.

Tectonic activity has complicated the hydrogeology of Yucca Flat. Major folding has brought the quartzite confining unit near land surface where it juxtaposes the lower carbonate-rock aquifer (Winograd and Thordarson, 1975, p. 63). Pre-Tertiary thrust faults have moved sections of older carbonate rocks over the Eleana confining unit. Late Tertiary and more recent, high-angle, extensional faults cut north-south through Yucca Flat. These faults, which include the Yucca and Carpetbag faults (fig. 3), have vertical offsets of 500 to more than 1,000 ft at depth (Phelps and McKee, 1999). Folds and faults in Yucca Flat have compartmentalized the flow system and restricted regional ground-water flow in areas where aquifers juxtapose confining units. Faults also have been hypothesized to juxtapose shallow and deep aquifers, creating vertical pathways for water to short-circuit confining units (Winograd and Thordarson, 1975, p. 55).

Yucca Flat is within the Death Valley regional groundwater flow system (Harrill and others, 1988, sheet 1) and, more specifically, within the Ash Meadows ground-water subbasin (Laczniak and others, 1996, p. 21). Regional groundwater flow generally is from north to south through the lower carbonate-rock aquifer (fig. 1). Less than $350 \mathrm{acre-ft/yr}$ is estimated to flow through the lower carbonate-rock aquifer beneath Yucca Flat (Winograd and Thordarson, 1975, p. 94). Flow is limited because the basin is bounded by confining units on the west, north, northeast, and from above (Laczniak and others, 1996, p. 26). Horizontal hydraulic gradients are large on the north and west sides of Yucca Flat, but relatively small east of the Carpetbag fault (Doty and Thordarson, 1983; Hale and others, 1995). Natural vertical hydraulic gradients generally are downward from the volcanic rocks to the lower carbonate-rock aquifer (Winograd and Thordarson, 1975, p. 54).

Several notable hydraulic features have been mapped in the potentiometric surface of the valley-fill and volcanic rocks. Areas of high hydraulic head, referred to as "groundwater mounds," were mapped in the water table east of the
Carpetbag fault (Hale and others, 1995). Some of these areas of high hydraulic head, between the Carpetbag and Yucca faults in the northern half of Yucca Flat, are caused by underground nuclear tests. In areas where valley-fill deposits are at the water table (fig. 3), ground-water mounding may occur following a nuclear test because of decreases in the porosity and permeability of the saturated deposits. In other areas, high-pressure zones occur in the tuff confining unit, a unit that was used extensively for underground nuclear tests.

Most of the recharge to Yucca Flat is subsurface inflow through the lower carbonate-rock aquifer from the northeast and west (Winograd and Thordarson, 1975, p. 94). This inflow is derived from precipitation that occurs on the mountain ranges to the west, north or northeast, such as the Belted Range (fig. 1). Precipitation in the surrounding highlands of Yucca Flat also may contribute small amounts of recharge to the basin, especially through ephemeral drainages from the highlands. Some recharge may reach the lower carbonate-rock aquifer from the shallow Cenozoic rocks within central Yucca Flat through a hydraulic sink at the Yucca/Carpetbag fault system (Winograd and Thordarson, 1975, p. 54-57). Other potential pathways for recharge are through fissures in Yucca Lake (fig. 2; Doty and Rush, 1985) and through subsidence craters from underground nuclear tests (Hokett and others, 2000).

Ground water discharges from Yucca Flat through the lower carbonate-rock aquifer by lateral flow into Frenchman Flat and ultimately to Ash Meadows or other downgradient discharge areas (fig. 1; Laczniak and others, 1996, p. 26). Since 1952, ground water also has been withdrawn from wells throughout Yucca Flat (fig. 2).

\section{Water-Level Measurements}

The USGS collects and maintains water-level data on the Nevada Test Site. As part of this data-collection program, current and historic water-level data are compiled, reviewed, and stored in the USGS NWIS database. In Yucca Flat and vicinity, the database has almost 4,000 water-level measurements from 216 wells where data were collected periodically from 1951 to 2003 (fig. 2; table 1). A well, for the purposes of the NWIS database and this report, describes a discrete open interval in a borehole. Therefore, a single borehole may be referenced to multiple wells. As an example, water-level measurements were made in some boreholes as the hole was progressively deepened. In these cases, a unique well identification number and name were established in the database for each depth in which levels were measured. In other cases, multiple piezometers, open at different intervals and hydraulically isolated from one another, were placed in a single borehole. In these cases, each piezometer is considered a distinct well. Wells from the same borehole typically are distinguished from each other by a parenthetical expression at the end of the well name-for example, ER-2-1 (2079 ft). 
Latitude and longitude: Referenced to North American Datum of 1983 (NAD83).

Land-surface altitude: Altitude relative to sea level.

Open interval: Area of well that is open to aquifer and where, if saturated, ground water may enter well. Open interval consists of open borehole and(or) well screen, including gravel packs. Where multiple open intervals occur, depths are in feet below land surface to top of uppermost interval and bottom of lowermost interval.

Contributing units: Lithologic units contributing water to well. Multiple units for single well listed in order of their likely importance in contributing water to well. Abbreviations: C, pre-Tertiary carbonate rock; F, valley fill; P, Paleocolluvium; S, pre-Tertiary clastic rock; V, volcanic tuffs; (V), volcanic tuffs within valley fill; X, igneous or metamorphic rocks; *, hole was dry and contributing unit listed is the unit at bottom of hole.

[Symbol: --, not available]

\begin{tabular}{|c|c|c|c|c|c|c|c|c|c|}
\hline \multirow[b]{2}{*}{$\begin{array}{l}\text { U.S. Geological Survey } \\
\text { well name } \\
\text { (see fig. 2) }\end{array}$} & \multirow[b]{2}{*}{$\begin{array}{c}\text { U.S. Geological Survey } \\
\text { site identification } \\
\text { number }\end{array}$} & \multirow[b]{2}{*}{ Nevada Test Site hole name ${ }^{2}$} & \multirow[b]{2}{*}{$\begin{array}{l}\text { Latitude } \\
\text { (decimal } \\
\text { degrees) }\end{array}$} & \multirow[b]{2}{*}{$\begin{array}{l}\text { Longitude } \\
\text { (decimal } \\
\text { degrees) }\end{array}$} & \multirow{2}{*}{$\begin{array}{l}\text { Land- } \\
\text { surface } \\
\text { altitude } \\
\text { (feet) }\end{array}$} & \multirow[b]{2}{*}{$\begin{array}{l}\text { Depth } \\
\text { drilled } \\
\text { (feet) }\end{array}$} & \multicolumn{2}{|c|}{ Open interval } & \multirow[b]{2}{*}{$\begin{array}{l}\text { Contributing } \\
\text { units }\end{array}$} \\
\hline & & & & & & & $\begin{array}{c}\text { Depth to } \\
\text { top } \\
\text { (feet) }\end{array}$ & $\begin{array}{l}\text { Depth to } \\
\text { bottom } \\
\text { (feet) }\end{array}$ & \\
\hline $\mathrm{R}-2-1(2079 \mathrm{ft})$ & 370725116033901 & ER-2-1 & 37.125230 & 116.062768 & 4,216 & 2,600 & 1,642 & 2,177 & $\mathrm{~V}$ \\
\hline $\mathrm{R}-2-1(2559 \mathrm{ft})$ & 370725116033902 & ER-2-1 & 37.125230 & 116.062768 & 4,216 & 2,600 & 2,313 & 2,600 & V \\
\hline R-3-1-1 (deep) & 370116115561301 & ER-3-1 & 37.019251 & 115.936776 & 4,407 & 2,807 & 2,512 & 2,807 & $\mathrm{C}$ \\
\hline R-3-1-2 (shallow) & 370116115561302 & ER-3-1 & 37.019251 & 115.936776 & 4,407 & 2,807 & 2,208 & 2,310 & $\mathrm{C}$ \\
\hline R-3-2-1 (deep) & 370214116021001 & ER-3-2 & 37.037130 & 116.037071 & 4,010 & 3,000 & 2,860 & 3,000 & $\mathrm{~V}$ \\
\hline R-3-2-2 (middle) & 370214116021002 & ER-3-2 & 37.037130 & 116.037071 & 4,010 & 3,000 & 2,588 & 2,636 & $\mathrm{~F}, \mathrm{~V}$ \\
\hline $\mathrm{R}-3-2-3$ (shallow) & 370214116021003 & ER-3-2 & 37.037130 & 116.037071 & 4,010 & 3,000 & 1,550 & 1,890 & $\mathrm{~F}$ \\
\hline R-6-1 (piezometer)) & 365904115593403 & ER-6-1 & 36.984409 & 115.993733 & 3,937 & 2,129 & 1,435 & 1,542 & V \\
\hline R-6-1 main $(2129 \mathrm{ft})$ & 365904115593404 & ER-6-1 & 36.984400 & 115.993730 & 3,935 & 2,129 & 1,819 & 2,129 & $\mathrm{C}$ \\
\hline R-6-1 main (2243ft) & 365904115593405 & ER-6-1 & 36.984409 & 115.993730 & 3,937 & 3,206 & 1,819 & 2,243 & $\mathrm{C}$ \\
\hline R-6-1 main (3206ft) & 365904115593401 & ER-6-1 & 36.984409 & 115.993730 & 3,937 & 3,206 & 1,819 & 3,206 & $\mathrm{C}$ \\
\hline R-6-1-1 & 365904115593402 & ER-6-1 \#1 & 36.984272 & 115.993697 & 3,937 & 2,085 & 1,835 & 2,052 & $\mathrm{C}$ \\
\hline R-6-1-2 (1587ft) & 365901115593502 & ER-6-1 \#2 & 36.983853 & 115.993919 & 3,935 & 3,200 & 120 & 1,587 & $\mathrm{~V}$ \\
\hline$R-6-1-2(3200 \mathrm{ft})$ & 365901115593501 & ER-6-1 \#2 & 36.983853 & 115.993919 & 3,935 & 3,200 & 1,775 & 3,200 & $C, X$ \\
\hline R-6-2 & 365740116043501 & ER-6-2 & 36.960983 & 116.077128 & 4,231 & 3,430 & 1,746 & 3,430 & $\mathrm{C}, \mathrm{S}$ \\
\hline $\mathrm{R}-7-1$ & 370424115594301 & ER-7-1 & 37.073278 & 115.996131 & 4,246 & 2,500 & 1,775 & 2,500 & $\mathrm{C}$ \\
\hline $\mathrm{R}-8-1$ & 371248116032101 & ER-8-1 & 37.213158 & 116.056541 & 4,818 & 2,863 & 1,895 & 2,863 & $\mathrm{X}$ \\
\hline $\mathrm{R}-12-1(1641-1846 \mathrm{ft})$ & 371106116110401 & ER-12-1 & 37.184856 & 116.185093 & 5,817 & 3,588 & 1,641 & 1,846 & C, S, X \\
\hline $\mathrm{R}-12-1(3309-3414 \mathrm{ft})$ & 371106116110402 & ER-12-1 & 37.184856 & 116.185093 & 5,817 & 3,588 & 3,309 & 3,442 & $\mathrm{C}$ \\
\hline $\mathrm{R}-12-2(2964-5203 \mathrm{ft})$ & 371019116072103 & ER-12-2 & 37.171479 & 116.123385 & 4,705 & 6,883 & 2,964 & 5,203 & $S, X$ \\
\hline$R-12-2(2964-6883 \mathrm{ft})$ & 371019116072101 & ER-12-2 & 37.171479 & 116.123385 & 4,705 & 6,883 & 2,964 & 6,883 & S, X \\
\hline$R-12-2(5203-6883 \mathrm{ft})$ & 371019116072102 & ER-12-2 & 37.171479 & 116.123385 & 4,705 & 6,883 & 5,203 & 6,883 & S, X \\
\hline $\mathrm{R}-12-2(579 \mathrm{ft})$ & 371019116072104 & ER-12-2 & 37.171479 & 116.123385 & 4,705 & 6,883 & 120 & 650 & $\mathrm{~V}, \mathrm{~F}, \mathrm{~S}$ \\
\hline ME-1 & 371340116035201 & Marble \#1 [ME-1] & 37.227802 & 116.065314 & 5,210 & 378 & 32 & 378 & $\mathrm{X}$ \\
\hline UE-2 & 371352116034601 & Marble \#2 [ME-2] & 37.231094 & 116.063522 & 5,246 & 274 & 14 & 274 & $\mathrm{X}$ \\
\hline ME-3 & 371346116035801 & Marble \#3 [ME-3] & 37.229508 & 116.066883 & 5,316 & 978 & 20 & 978 & $X$ \\
\hline UE-4 & 371400116041101 & Marble \#4 [ME-4] & 37.233338 & 116.070672 & 5,490 & 1,187 & 7 & 1,187 & $\mathrm{X}$ \\
\hline $\mathrm{H}-9$ & 370311115591901 & Test Hole \#9 & 37.053014 & 115.989347 & 4,176 & 1,953 & 80 & 1,953 & $\mathrm{C}, \mathrm{V}$ \\
\hline W-7 & 370353116020201 & Test Well \#7 [HTH] & 37.064817 & 116.034644 & 4,058 & 2,272 & 0 & 2,272 & $\mathrm{~V}$ \\
\hline
\end{tabular}




\begin{tabular}{|c|c|c|c|c|c|c|c|c|c|}
\hline \multirow[b]{2}{*}{$\begin{array}{l}\text { U.S. Geological Survey } \\
\text { well name } \\
\text { (see fig. 2) }\end{array}$} & \multirow[b]{2}{*}{$\begin{array}{c}\text { U.S. Geological Survey } \\
\text { site identification } \\
\text { number }{ }^{1}\end{array}$} & \multirow[b]{2}{*}{ Nevada Test Site hole name ${ }^{2}$} & \multirow[b]{2}{*}{$\begin{array}{l}\text { Latitude } \\
\text { (decimal } \\
\text { degrees) }\end{array}$} & \multirow[b]{2}{*}{$\begin{array}{l}\text { Longitude } \\
\text { (decimal } \\
\text { degrees) }\end{array}$} & \multirow{2}{*}{$\begin{array}{l}\text { Land- } \\
\text { surface } \\
\text { altitude } \\
\text { (feet) }\end{array}$} & \multirow[b]{2}{*}{$\begin{array}{l}\text { Depth } \\
\text { drilled } \\
\text { (feet) }\end{array}$} & \multicolumn{2}{|c|}{ Open interval } & \multirow[b]{2}{*}{$\begin{array}{l}\text { Contributing } \\
\text { units }\end{array}$} \\
\hline & & & & & & & $\begin{array}{l}\text { Depth to } \\
\text { top } \\
\text { (feet) }\end{array}$ & $\begin{array}{l}\text { Depth to } \\
\text { bottom } \\
\text { (feet) }\end{array}$ & \\
\hline TW-B & 365849116002101 & USGS Test Well B Ex. & 36.979150 & 116.014617 & 3,932 & 1,675 & 1,432 & 1,675 & $\mathrm{~V}$ \\
\hline TW-D & 370418116044501 & USGS Test Well D & 37.074391 & 116.075887 & 4,150 & 1,950 & 1,700 & 1,950 & $\mathrm{C}, \mathrm{S}$ \\
\hline TW-E (1970 ft) & 370321115594201 & USGS HTH E & 37.055797 & 115.995834 & 4,172 & 1,970 & 580 & 1,970 & $\mathrm{~V}$ \\
\hline TW-E (2430 ft) & 370321115594202 & USGS HTH E & 37.055797 & 115.995834 & 4,172 & 2,430 & 0 & 2,430 & $\mathrm{C}, \mathrm{V}$ \\
\hline TW-E (2620 ft) & 370321115594203 & USGS HTH E & 37.055797 & 115.995834 & 4,172 & 2,620 & 0 & 2,620 & $\mathrm{C}, \mathrm{V}$ \\
\hline $\mathrm{U}-2 \mathrm{av}$ & 370836116035001 & $\mathrm{U}-2 \mathrm{av}$ & 37.143269 & 116.064715 & 4,298 & 2,193 & 79 & 2,193 & $\mathrm{~V}$ \\
\hline $\mathrm{U}-2 \mathrm{az} 1$ & 370648116034401 & $\mathrm{U}-2 \mathrm{az} \# 1$ & 37.113319 & 116.063204 & 4,192 & 1,820 & 58 & 1,820 & $\mathrm{~V}$ \\
\hline $\mathrm{U}-2 \mathrm{bs}$ & 370723116033101 & $\mathrm{U}-2 \mathrm{bs}$ & 37.123000 & 116.059384 & 4,226 & 2,000 & 79 & 1,920 & $\mathrm{~V}$ \\
\hline U-2bs PS 1DB & 370722116032252 & U-2bs PS \#1DB & 37.122844 & 116.056912 & 4,221 & 2,250 & 2,165 & 2,175 & $\mathrm{~V}$ \\
\hline $\mathrm{U}-2 \mathrm{bt}$ & 370641116030501 & $\mathrm{U}-2 \mathrm{bt}$ & 37.111450 & 116.052278 & 4,182 & 1,800 & 77 & 1,800 & $\mathrm{~V}$ \\
\hline U-2ca 1 & 370822116082701 & U-2ca \#1 [UE-2u] & 37.139510 & 116.141772 & 4,871 & 1,473 & 68 & 1,473 & $\mathrm{C}, \mathrm{V}$ \\
\hline $\mathrm{U}-2 \mathrm{df}$ & 370822116051501 & $\mathrm{U}-2 \mathrm{df}$ & 37.139466 & 116.088314 & 4,354 & 1,865 & 78 & 1,865 & $\mathrm{~V}, \mathrm{~F}$ \\
\hline $\mathrm{U}-2 \mathrm{dr}$ & 370802116050301 & $\mathrm{U}-2 \mathrm{dr}$ & 37.133963 & 116.085116 & 4,313 & 2,020 & 117 & 2,000 & $\mathrm{~F}$ \\
\hline U-2eh & 370900116045601 & U-2eh & 37.149827 & 116.083133 & 4,368 & 2,250 & 117 & 2,250 & $\mathrm{~V}, \mathrm{~F}$ \\
\hline U-2ei & 370904116040301 & U-2ei & 37.151116 & 116.068430 & 4,327 & 2,100 & 117 & 2,100 & $\mathrm{~V}$ \\
\hline $\mathrm{U}-2 \mathrm{ex}$ & 370826116041901 & $\mathrm{U}-2 \mathrm{ex}$ & 37.140400 & 116.072938 & 4,311 & 2,009 & 118 & 2,009 & $\mathrm{~V}$ \\
\hline $\mathrm{U}-2 \mathrm{gf}$ & 370728116042001 & $\mathrm{U}-2 \mathrm{gf}$ & 37.124386 & 116.072996 & 4,249 & 1,810 & 118 & 1,810 & $\mathrm{~V}$ \\
\hline U-2gg & 370834116040101 & $\mathrm{U}-2 \mathrm{gg}$ & 37.142791 & 116.067807 & 4,289 & 1,821 & 117 & 1,821 & $\mathrm{~V}^{*}$ \\
\hline U-2gg PS E3A & 370837116040901 & U-2gg PSE \#3A & 37.143602 & 116.070166 & 4,311 & 2,383 & 939 & 2,383 & $\mathrm{~V}$ \\
\hline $\mathrm{U}-2 \mathrm{gh}$ & 370645116031901 & $\mathrm{U}-2 \mathrm{gh}$ & 37.112455 & 116.056048 & 4,177 & 1,801 & 117 & 1,801 & $\mathrm{~V}$ \\
\hline $\mathrm{U}-2 \mathrm{gk}$ & 370720116041601 & $\mathrm{U}-2 \mathrm{gk}$ & 37.122305 & 116.072082 & 4,242 & 1,809 & 116 & 1,809 & $\mathrm{~F}$ \\
\hline $\mathrm{U}-2 \mathrm{v}$ & 370737116035901 & $\mathrm{U}-2 \mathrm{v}$ & 37.126802 & 116.067249 & 4,256 & 2,530 & 73 & 2,530 & $\mathrm{~V}$ \\
\hline U-3an 3 & 370353116021401 & U-3an \#3 & 37.064908 & 116.038047 & 4,061 & 3,555 & 3,262 & 3,555 & $\mathrm{C}$ \\
\hline U-3en 1 & 370338116011801 & U-3en \#1 & 37.060453 & 116.022635 & 4,074 & 2,460 & 2,000 & 2,460 & $\mathrm{~V}$ \\
\hline $\mathrm{U}-3 \operatorname{cn} 3$ & 370339116011901 & $\mathrm{U}-3 \mathrm{cn} \# 3$ & 37.060706 & 116.022938 & 4,075 & 2,460 & 2,005 & 2,460 & $\mathrm{~V}$ \\
\hline U-3en 4 HTH & 370355116013001 & U-3cn \#4 HTH & 37.065192 & 116.025924 & 4,084 & 2,295 & 1,697 & 2,295 & $\mathrm{~V}$ \\
\hline $\mathrm{U}-3 \operatorname{cn} 5$ & 370320116012001 & $\begin{array}{l}\text { U-3cn \#5 [BILBY Hydrologic Test } \\
\text { Hole] }\end{array}$ & 37.059433 & 116.023232 & 4,009 & 3,030 & 2,832 & 3,030 & $\mathrm{C}, \mathrm{X}$ \\
\hline $\mathrm{U}-3 \mathrm{cn}$ PS 2 & 370338116011901 & U-3en PS \#2 & 37.060372 & 116.022638 & 3,994 & 2,603 & 600 & 2,603 & V \\
\hline U-3jg & 370017116014201 & U-3jg & 37.004786 & 116.029335 & 3,962 & 1,650 & 118 & 1,650 & $\mathrm{~F}$ \\
\hline $\mathrm{U}-3 \mathrm{jn} 1$ & 370326116021101 & U-3jn Ex. \#1/Inst. & 37.057144 & 116.037369 & 4,046 & 2,000 & 1,354 & 2,000 & V \\
\hline $\mathrm{U}-3 \mathrm{jq} 1$ & 370353116000601 & U-3jq Ex. \#1/Inst. & 37.064656 & 116.002442 & 4,174 & 2,224 & 118 & 2,224 & $\mathrm{~V}, \mathrm{~S}, \mathrm{C}$ \\
\hline
\end{tabular}




\begin{tabular}{|c|c|c|c|c|c|c|c|c|c|}
\hline \multirow[b]{2}{*}{$\begin{array}{l}\text { U.S. Geological Survey } \\
\text { well name } \\
\text { (see fig. 2) }\end{array}$} & \multirow[b]{2}{*}{$\begin{array}{c}\text { U.S. Geological Survey } \\
\text { site identification } \\
\text { number }^{1}\end{array}$} & \multirow[b]{2}{*}{ Nevada Test Site hole name ${ }^{2}$} & \multirow[b]{2}{*}{$\begin{array}{l}\text { Latitude } \\
\text { (decimal } \\
\text { degrees) }\end{array}$} & \multirow[b]{2}{*}{$\begin{array}{l}\text { Longitude } \\
\text { (decimal } \\
\text { degrees) }\end{array}$} & \multirow[b]{2}{*}{$\begin{array}{l}\text { Land- } \\
\text { surface } \\
\text { altitude } \\
\text { (feet) }\end{array}$} & \multirow[b]{2}{*}{$\begin{array}{c}\text { Depth } \\
\text { drilled } \\
\text { (feet) }\end{array}$} & \multicolumn{2}{|c|}{ Open interval } & \multirow[b]{2}{*}{$\begin{array}{l}\text { Contributing } \\
\text { units }\end{array}$} \\
\hline & & & & & & & $\begin{array}{c}\text { Depth to } \\
\text { top } \\
\text { (feet) }\end{array}$ & $\begin{array}{l}\text { Depth to } \\
\text { bottom } \\
\text { (feet) }\end{array}$ & \\
\hline $\mathrm{U}-3 \mathrm{ks}$ & 370053116002901 & U-3ks & 37.014700 & 116.008873 & 3,966 & 1,613 & 117 & 1,610 & $\mathrm{~V}$ \\
\hline $\mathrm{U}-3 \mathrm{kv}$ & 370020116003701 & $\mathrm{U}-3 \mathrm{kv}$ & 37.005372 & 116.011009 & 3,956 & 1,600 & 117 & 1,600 & V \\
\hline $\mathrm{U}-3 \mathrm{kz}$ & 370409116025901 & $\mathrm{U}-3 \mathrm{kz}$ & 37.069033 & 116.050561 & 4,084 & 2,250 & 117 & 2,198 & V \\
\hline $\mathrm{U}-3 \mathrm{mh}$ & 370157115591401 & $\mathrm{U}-3 \mathrm{mh}$ & 37.032436 & 115.988169 & 4,092 & 1,742 & 268 & 1,742 & $\mathrm{~V}^{*}$ \\
\hline $\mathrm{U}-3 \mathrm{mi}$ & 370020115593001 & $\mathrm{U}-3 \mathrm{mi}$ & 37.005661 & 115.992650 & 4,006 & 1,794 & 372 & 1,794 & $\mathrm{~V}, \mathrm{C}$ \\
\hline $\mathrm{U}-3 \mathrm{mt}$ & 370348116024301 & $\mathrm{U}-3 \mathrm{mt}$ & 37.063383 & 116.046158 & 4,067 & 1,550 & 110 & 1,550 & V \\
\hline U-4ak & 370435116040701 & U-4ak & 37.076272 & 116.069359 & 4,130 & 1,630 & 120 & 1,630 & $\mathrm{~V}$ \\
\hline U-4au & 370509116040301 & U-4au & 37.085883 & 116.069387 & 4,144 & 1,750 & 117 & 1,750 & $\mathrm{~V}$ \\
\hline U-4av & 370547116041103 & U-4av & 37.096438 & 116.070482 & 4,178 & 1,700 & 117 & 1,700 & V \\
\hline $\mathrm{U}-4 \mathrm{r}$ & 370506116031001 & $\mathrm{U}-4 \mathrm{r}$ & 37.085180 & 116.053673 & 4,119 & 2,250 & 119 & 2,250 & V \\
\hline $\mathrm{U}-4 \mathrm{t} 1$ & 370601116025301 & U-4t \#1 & 37.100380 & 116.049075 & 4,144 & 2,100 & 118 & 2,100 & V \\
\hline $\mathrm{U}-4 \mathrm{u}(2112 \mathrm{ft})$ & 370520116025703 & $\mathrm{U}-4 \mathrm{u}$ & 37.088950 & 116.050134 & 4,120 & 2,112 & 118 & 2,112 & $\mathrm{~V}$ \\
\hline U-4u PS 2A & 370513116025101 & U-4u PS \#2A & 37.086928 & 116.050153 & 4,117 & 2,280 & 1,610 & 2,280 & V \\
\hline U-6e & 365934116001601 & U-6e & 36.992789 & 116.005364 & 3,942 & 1,500 & 117 & 1,500 & $\mathrm{~V}^{*}$ \\
\hline $\mathrm{U}-7 \mathrm{a}$ & 370626116015601 & U-7a & 37.107161 & 116.033111 & 4,255 & 2,699 & 2,438 & 2,699 & $\mathrm{C}, \mathrm{V}$ \\
\hline U-7ad (1853 ft) & 370613116013601 & U-7ad & 37.103544 & 116.027599 & 4,286 & 1,853 & 113 & 1,853 & V \\
\hline U-7ad (1965 ft) & 370613116013602 & U-7ad & 37.103544 & 116.027599 & 4,286 & 1,965 & 113 & 1,965 & V \\
\hline U-7ae (2056 ft) & 370512116002501 & $\mathrm{U}-7 \mathrm{ae}$ & 37.086522 & 116.007737 & 4,266 & 2,056 & 675 & 2,056 & $\mathrm{~V}$ \\
\hline U-7ag & 370632116014401 & U-7ag & 37.108806 & 116.029666 & 4,286 & 1,975 & 565 & 1,975 & $\mathrm{~V}$ \\
\hline $\mathrm{U}-7 \mathrm{au}$ & 370447116030501 & $\mathrm{U}-7 \mathrm{au}$ & 37.079755 & 116.052192 & 4,111 & 2,440 & 117 & 1,609 & V \\
\hline U-7ba & 370514116024101 & U-7ba & 37.087041 & 116.045620 & 4,129 & 2,000 & 117 & 1,504 & $\mathrm{~V}$ \\
\hline U-7ba PS 1AS & 370517116023301 & U-7ba PS \#1AS & 37.088022 & 116.043283 & 4,137 & 2,333 & 1,935 & 1,993 & $\mathrm{~V}$ \\
\hline $\mathrm{U}-7 \mathrm{bc}$ & 370444116001801 & $\mathrm{U}-7 \mathrm{bc}$ & 37.078936 & 116.005990 & 4,229 & 2,250 & 117 & 2,250 & $\mathrm{~V}$ \\
\hline U-7bd & 370454116003201 & U-7bd & 37.081572 & 116.009621 & 4,224 & 2,000 & 117 & 2,000 & $\mathrm{~V}$ \\
\hline $\mathrm{U}-7 \mathrm{bL}$ & 370554116005601 & $\mathrm{U}-7 \mathrm{bL}$ & 37.098242 & 116.016379 & 4,317 & 1,810 & 397 & 1,810 & $\mathrm{~V}^{*}$ \\
\hline U-7bz (817-2188ft) & 370530116015501 & $\mathrm{U}-7 \mathrm{bz}$ & 37.091744 & 116.032722 & 4,176 & 2,188 & 817 & 2,188 & $\mathrm{~V}, \mathrm{C}$ \\
\hline $\mathrm{U}-7 \mathrm{ca}$ & 370436116000201 & U-7ca & 37.076736 & 116.001481 & 4,244 & 1,800 & 268 & 1,800 & $\mathrm{~V}$ \\
\hline $\mathrm{U}-7 \mathrm{cb}$ & 370514116000601 & $\mathrm{U}-7 \mathrm{cb}$ & 37.087286 & 116.002656 & 4,286 & 1,850 & 299 & 1,850 & $\mathrm{~V}$ \\
\hline $\mathrm{U}-7 \mathrm{cc}$ & 370605116012401 & $\mathrm{U}-7 \mathrm{cc}$ & 37.101311 & 116.024244 & 4,286 & 1,600 & 556 & 1,600 & V \\
\hline U-7cd & 370451116024101 & $\mathrm{U}-7 \mathrm{~cd}$ & 37.080819 & 116.045669 & 4,115 & 1,625 & 117 & 1,625 & V \\
\hline U-7cd 1 & 370451116024102 & U-7cd \#1 & 37.080825 & 116.045564 & 4,114 & 1,700 & 114 & 1,700 & $\mathrm{~V}$ \\
\hline $\mathrm{U}-7 \mathrm{z}$ & 370455116021201 & $\mathrm{U}-7 \mathrm{z}$ & 37.082011 & 116.037436 & 4,108 & 1,903 & 116 & 1,903 & $\mathrm{~V}$ \\
\hline $\mathrm{U}-8 \mathrm{j}$ & 371048116052001 & $\mathrm{U}-8 \mathrm{j}$ & 37.179927 & 116.089828 & 4,556 & 2,000 & 119 & 2,000 & $\mathrm{~V}, \mathrm{~S}, \mathrm{X}$ \\
\hline $\mathrm{U}-8 \mathrm{n}$ & 371031116053001 & $\mathrm{U}-8 \mathrm{n}$ & 37.175271 & 116.092609 & 4,542 & 1,893 & 118 & 1,893 & V \\
\hline U-9 ITS UE-S-25 & 370819116022901 & U-9 ITS UE-S-25 & 37.138455 & 116.042126 & 4,222 & 2,028 & 79 & 2,028 & $\mathrm{~V}$ \\
\hline
\end{tabular}




\begin{tabular}{|c|c|c|c|c|c|c|c|c|c|}
\hline \multirow[b]{2}{*}{$\begin{array}{l}\text { U.S. Geological Survey } \\
\text { well name } \\
\text { (see fig. 2) }\end{array}$} & \multirow[b]{2}{*}{$\begin{array}{c}\text { U.S. Geological Survey } \\
\text { site identification } \\
\text { number }^{1}\end{array}$} & \multirow[b]{2}{*}{ Nevada Test Site hole name ${ }^{2}$} & \multirow[b]{2}{*}{$\begin{array}{l}\text { Latitude } \\
\text { (decimal } \\
\text { degrees) }\end{array}$} & \multirow[b]{2}{*}{$\begin{array}{l}\text { Longitude } \\
\text { (decimal } \\
\text { degrees) }\end{array}$} & \multirow[b]{2}{*}{$\begin{array}{l}\text { Land- } \\
\text { surface } \\
\text { altitude } \\
\text { (feet) }\end{array}$} & \multirow[b]{2}{*}{$\begin{array}{l}\text { Depth } \\
\text { drilled } \\
\text { (feet) }\end{array}$} & \multicolumn{2}{|c|}{ Open interval } & \multirow[b]{2}{*}{$\begin{array}{l}\text { Contributing } \\
\text { units }\end{array}$} \\
\hline & & & & & & & $\begin{array}{l}\text { Depth to } \\
\text { top } \\
\text { (feet) }\end{array}$ & $\begin{array}{l}\text { Depth to } \\
\text { bottom } \\
\text { (feet) }\end{array}$ & \\
\hline U-9ca 1 & 370846116030851 & U-9ca \#1 & 37.145958 & 116.053037 & 4,244 & 3,210 & 1,800 & 3,210 & $\mathrm{~V}, \mathrm{C}$ \\
\hline U-9ct & 370815116032701 & U-9ct & 37.137472 & 116.058415 & 4,264 & 1,710 & 117 & 1,710 & $\mathrm{~V}^{*}$ \\
\hline U-10k 1 & 370953116030801 & U-10k \#1 Expl./Inst. & 37.164566 & 116.053118 & 4,272 & 2,289 & 1,983 & 2,275 & V \\
\hline U-10L 1 & 370917116023701 & $\mathrm{U}-10 \mathrm{~L} \# 1$ & 37.154753 & 116.044520 & 4,264 & 2,208 & 1,375 & 2,208 & $\mathrm{C}, \mathrm{V}$ \\
\hline $\mathrm{U}-15 \mathrm{a} 31(1200 \mathrm{ft})$ & 371335116033401 & U-15a \#31 [Granite Hole] & 37.226216 & 116.060186 & 5,112 & 1,200 & 88 & 1,200 & $\mathrm{X}$ \\
\hline U-15k Test Hole & 371346116032601 & U-15k Test Hole (Granite Bit) & 37.229450 & 116.057991 & 5,168 & 857 & 404 & 857 & $\mathrm{X}$ \\
\hline UE-1a & 370254116070601 & UE-1a & 37.048227 & 116.119270 & 4,304 & 957 & 78 & 957 & $\mathrm{C}, \mathrm{S}$ \\
\hline UE-1b & 370254116064201 & UE-1b & 37.048196 & 116.112417 & 4,273 & 1,254 & 76 & 1,254 & $\mathrm{~S}, \mathrm{~V}$ \\
\hline UE-1c & 370253116055201 & UE-1c & 37.048130 & 116.098710 & 4,207 & 1,880 & 74 & 1,880 & $\mathrm{C}, \mathrm{V}$ \\
\hline UE-1d & 370301116065301 & UE-1d & 37.050127 & 116.115656 & 4,296 & 857 & 79 & 857 & $\mathrm{C}, \mathrm{V}$ \\
\hline UE-1f & 370246116064901 & UE-1f & 37.046035 & 116.114581 & 4,277 & 703 & 59 & 703 & $S, X$ \\
\hline UE-1h & 370005116040301 & UE-1h & 37.001286 & 116.068242 & 3,995 & 3,358 & 2,134 & 3,358 & $\mathrm{C}$ \\
\hline UE-1j & 370049116042401 & UE- $1 j$ & 37.013669 & 116.074131 & 4,030 & 1,632 & 108 & 1,632 & $\mathrm{C}$ \\
\hline UE-1k & 370218116033101 & UE-1k & 37.038316 & 116.059378 & 4,051 & 2,338 & 110 & 2,338 & $\mathrm{~V}, \mathrm{~F}$ \\
\hline UE-1L (5339 ft) & 370254116082001 & UE-1L & 37.048324 & 116.139826 & 4,457 & 5,339 & 716 & 5,339 & S \\
\hline UE-1L (recompleted) & 370254116082002 & UE-1L & 37.048324 & 116.139826 & 4,457 & 5,339 & 716 & 2,284 & $\mathrm{~S}$ \\
\hline UE-1q (2437 ft) & 370337116033001 & UE-1q & 37.060294 & 116.059203 & 4,081 & 2,437 & 78 & 2,437 & $\mathrm{~V}, \mathrm{C}$ \\
\hline UE-1q (2600 ft) & 370337116033002 & UE-1q & 37.060294 & 116.059203 & 4,081 & 2,600 & 2,459 & 2,600 & $\mathrm{C}$ \\
\hline UE-1r WW & 370142116033301 & UE-1r & 37.028302 & 116.060145 & 4,042 & 4,182 & 2,319 & 4,182 & $\mathrm{C}, \mathrm{V}, \mathrm{X}$ \\
\hline UE-2aa (2207 ft) & 370909116041951 & UE-2aa & 37.152375 & 116.072880 & 4,348 & 2,317 & 77 & 2,207 & $\mathrm{~V}$ \\
\hline UE-2aa (2317 ft) & 370909116041901 & UE-2aa & 37.152375 & 116.072880 & 4,348 & 2,317 & 77 & 2,317 & $\mathrm{C}, \mathrm{V}$ \\
\hline UE-2ab & 370849116054301 & UE-2ab & 37.146996 & 116.096256 & 4,413 & 1,270 & 80 & 1,270 & $C^{*}$ \\
\hline UE-2ar & 370726116040302 & UE-2ar Inst. & 37.123769 & 116.068452 & 4,241 & 2,351 & 81 & 2,351 & $\mathrm{~V}, \mathrm{~F}$ \\
\hline UE-2aw & 370758116040601 & UE-2aw/Inst. & 37.132638 & 116.069329 & 4,272 & 2,328 & 77 & 2,328 & $\mathrm{~V}$ \\
\hline UE-2ax 2 & 370910116045901 & UE-2ax \#2 & 37.152591 & 116.083927 & 4,396 & 2,450 & 72 & 2,450 & $\mathrm{~V}$ \\
\hline UE-2b & 370748116051201 & UE-2b & 37.129994 & 116.087441 & 4,310 & 3,512 & 120 & 3,512 & $\mathrm{~V}, \mathrm{C}$ \\
\hline UE-2ce & 370831116080701 & UE-2ce Water Well & 37.141968 & 116.136094 & 4,765 & 1,650 & 1,377 & 1,650 & $\mathrm{C}$ \\
\hline UE-2dj & 370823116050001 & UE-2dj/Inst. & 37.139797 & 116.084300 & 4,341 & 2,350 & 77 & 2,350 & $\mathrm{~V}, \mathrm{~S}$ \\
\hline $\mathrm{UE}-2 \mathrm{fb}$ & 370736116050301 & $\mathrm{UE}-2 \mathrm{fb}$ & 37.126616 & 116.084916 & 4,274 & 2,790 & 83 & 2,790 & $\mathrm{C}, \mathrm{V}$ \\
\hline UE-2s & 370712116073901 & UE-2s/Inst. & 37.119816 & 116.128465 & 4,583 & 1,970 & 1,050 & 1,970 & $\mathrm{C}$ \\
\hline UE-3e (1707 ft) & 370411116025901 & UE-3e & 37.069580 & 116.050614 & 4,083 & 1,707 & 117 & 1,707 & $\mathrm{~V}$ \\
\hline UE-3e (2105 ft) & 370411116025902 & UE-3e & 37.069580 & 116.050614 & 4,083 & 2,105 & 117 & 2,105 & $\mathrm{~V}$ \\
\hline UE-3e (2110 ft) & 370411116025905 & UE-3e & 37.069580 & 116.050614 & 4,083 & 2,510 & 117 & 2,110 & $\mathrm{~V}$ \\
\hline UE-3e (2118-2510 ft) & 370411116025906 & UE-3e & 37.069580 & 116.050614 & 4,083 & 2,510 & 2,118 & 2,510 & $\mathrm{~V}$ \\
\hline UE-3e (2410 ft) & 370411116025903 & UE-3e & 37.069580 & 116.050614 & 4,083 & 2,410 & 117 & 2,410 & $\mathrm{~V}$ \\
\hline UE-3e (2510 ft) & 370411116025904 & UE-3e & 37.069580 & 116.050614 & 4,083 & 2,510 & 117 & 2,510 & $\mathrm{~V}$ \\
\hline
\end{tabular}




\begin{tabular}{|c|c|c|c|c|c|c|c|c|c|}
\hline \multirow[b]{2}{*}{$\begin{array}{l}\text { U.S. Geological Survey } \\
\text { well name } \\
\text { (see fig. 2) }\end{array}$} & \multirow[b]{2}{*}{$\begin{array}{c}\text { U.S. Geological Survey } \\
\text { site identification } \\
\text { number }\end{array}$} & \multirow[b]{2}{*}{ Nevada Test Site hole name ${ }^{2}$} & \multirow[b]{2}{*}{$\begin{array}{l}\text { Latitude } \\
\text { (decimal } \\
\text { degrees) }\end{array}$} & \multirow[b]{2}{*}{$\begin{array}{l}\text { Longitude } \\
\text { (decimal } \\
\text { degrees) }\end{array}$} & \multirow[b]{2}{*}{$\begin{array}{l}\text { Land- } \\
\text { surface } \\
\text { altitude } \\
\text { (feet) }\end{array}$} & \multirow[b]{2}{*}{$\begin{array}{l}\text { Depth } \\
\text { drilled } \\
\text { (feet) }\end{array}$} & \multicolumn{2}{|c|}{ Open interval } & \multirow[b]{2}{*}{$\begin{array}{l}\text { Contributing } \\
\text { units }\end{array}$} \\
\hline & & & & & & & $\begin{array}{l}\text { Depth to } \\
\text { top } \\
\text { (feet) }\end{array}$ & $\begin{array}{l}\text { Depth to } \\
\text { bottom } \\
\text { (feet) }\end{array}$ & \\
\hline UE-3e 2 (2372 ft) & 370411116025907 & UE-3e \#2 & 37.069689 & 116.050617 & 4,082 & 2,372 & 1,950 & 2,372 & V \\
\hline UE-3e 3 (2221 ft) & 370411116025908 & UE-3e \#3 & 37.070114 & 116.048325 & 4,082 & 2,221 & 115 & 2,221 & $\mathrm{~V}^{*}$ \\
\hline UE-3e $4(2300 \mathrm{ft})$ & 370411116025909 & UE-3e \#4 & 37.069555 & 116.050558 & 4,081 & 2,300 & 1,436 & 2,300 & V \\
\hline UE-3e 4-1 (2181 ft) & 370411116025910 & UE-3e \#4 & 37.069555 & 116.050558 & 4,081 & 2,300 & 2,094 & 2,192 & $\mathrm{~V}$ \\
\hline UE-3e 4-2 (1919ft) & 370411116025911 & UE-3e \#4 & 37.069555 & 116.050558 & 4,081 & 2,300 & 1,832 & 1,926 & $\mathrm{~V}$ \\
\hline UE-3e 4-3 (1661 ft) & 370411116025912 & UE-3e \#4 & 37.069555 & 116.050556 & 4,081 & 2,300 & 1,540 & 1,668 & $\mathrm{~V}$ \\
\hline UE-3mf (119-1692 ft) & 370339116024206 & UE-3mf/Inst. & 37.060816 & 116.046111 & 4,066 & 2,395 & 119 & 1,692 & $\mathrm{~V}$ \\
\hline UE-3mf (119-1894 ft) & 370339116024204 & UE-3mf/Inst. & 37.060816 & 116.046111 & 4,066 & 2,395 & 119 & 1,894 & $\mathrm{~V}$ \\
\hline UE-3mf (1692-2395 ft) & 370339116024205 & UE-3mf/Inst. & 37.060816 & 116.046111 & 4,066 & 2,395 & 1,692 & 2,395 & V \\
\hline $\mathrm{UE}-3 \mathrm{mf}(1700 \mathrm{ft})$ & 370339116024201 & UE-3mf/Inst. & 37.060816 & 116.046111 & 4,066 & 1,700 & 119 & 1,700 & V \\
\hline UE-3mf (1894-2395 ft) & 370339116024203 & UE-3mf/Inst. & 37.060816 & 116.046111 & 4,066 & 2,395 & 1,894 & 2,395 & $\mathrm{~V}$ \\
\hline $\mathrm{UE}-3 \mathrm{mf}(2100 \mathrm{ft})$ & 370339116024202 & UE-3mf/Inst. & 37.060816 & 116.046111 & 4,066 & 2,100 & 119 & 2,100 & V \\
\hline UE-4a (2655 ft) & 370601116030103 & UE-4a (HTH) & 37.100189 & 116.051200 & 4,155 & 3,028 & 856 & 2,655 & V \\
\hline UE-4a (3028 ft) & 370601116030102 & UE-4a (HTH) & 37.100189 & 116.051200 & 4,155 & 3,028 & 2,886 & 3,028 & $\mathrm{C}, \mathrm{P}, \mathrm{V}$ \\
\hline UE-4aa & 370543116054101 & UE-4aa & 37.095205 & 116.095636 & 4,254 & 1,224 & 76 & 1,224 & $\mathrm{C}^{*}$ \\
\hline UE-4ab (2396 ft) & 370608116043102 & UE-4ab/Inst. & 37.102263 & 116.076185 & 4,201 & 2,650 & 71 & 2,396 & V \\
\hline UE-4ab (2650 ft) & 370608116043101 & UE-4ab/Inst. & 37.102263 & 116.076185 & 4,201 & 2,650 & 71 & 2,650 & $\mathrm{C}, \mathrm{V}, \mathrm{S}$ \\
\hline UE-4ac (1522 ft) & 370601116071402 & UE-4ac & 37.100282 & 116.121468 & 4,471 & 1,677 & 74 & 1,522 & V \\
\hline UE-4ac (1677 ft) & 370601116071401 & UE-4ac & 37.100282 & 116.121468 & 4,471 & 1,680 & 74 & 1,667 & $\mathrm{C}$ \\
\hline UE-4ae (2290 ft) & 370434116040702 & UE-4ae/Inst. & 37.075997 & 116.069362 & 4,130 & 2,457 & 79 & 2,290 & V \\
\hline UE-4ae (2457 ft) & 370434116040701 & UE-4ae/Inst. & 37.075997 & 116.069362 & 4,130 & 2,457 & 79 & 2,457 & $\mathrm{C}, \mathrm{V}$ \\
\hline UE-4ah & 370501116041301 & UE-4ah/Inst. & 37.083697 & 116.071015 & 4,142 & 2,851 & 79 & 2,851 & $\mathrm{C}, \mathrm{V}$ \\
\hline UE-4av (1724-2815 ft) & 370547116041102 & UE-4av & 37.096441 & 116.070651 & 4,177 & 2,815 & 1,724 & 2,815 & $\mathrm{~V}, \mathrm{P}, \mathrm{S}$ \\
\hline UE-4av (1758 ft) & 370547116041101 & UE-4av & 37.096441 & 116.070651 & 4,177 & 1,758 & 125 & 1,758 & V \\
\hline UE-4av (2815 ft) & 370547116041104 & UE-4av & 37.096441 & 116.070651 & 4,177 & 2,815 & 125 & 2,815 & $\mathrm{~V}, \mathrm{P}, \mathrm{S}$ \\
\hline UE-4t (1619-1721ft) & 370556116025404 & UE-4t & 37.098878 & 116.049128 & 4,141 & 2,413 & 1,619 & 1,721 & V \\
\hline UE-4t (1701ft) & 370556116025401 & UE-4t & 37.098878 & 116.049128 & 4,141 & 1,701 & 119 & 1,701 & $\mathrm{~V}$ \\
\hline UE-4t (1947 ft) & 370556116025402 & UE-4t & 37.098878 & 116.049128 & 4,141 & 1,947 & 119 & 1,947 & $\mathrm{~V}$ \\
\hline $\mathrm{UE}-4 \mathrm{t}(2413 \mathrm{ft})$ & 370556116025403 & UE-4t & 37.098878 & 116.049128 & 4,141 & 2,413 & 119 & 2,413 & $\mathrm{~V}$ \\
\hline UE-4t 1 (1906-2010 ft) & 370556116025405 & UE-4t & 37.098878 & 116.049128 & 4,141 & 2,413 & 1,906 & 2,010 & V \\
\hline UE-4t 2 (1564-1754 ft) & 370556116025406 & UE-4t & 37.098878 & 116.049128 & 4,141 & 2,413 & 1,564 & 1,754 & V \\
\hline UE-6d & 365905116033201 & UE-6d & 36.984758 & 116.059811 & 3,947 & 3,896 & 2,125 & 3,896 & $\mathrm{~F}, \mathrm{~V}$ \\
\hline UE-6e (2090-2230 ft) & 365905116012002 & UE-6e & 36.984564 & 116.023170 & 3,938 & 4,209 & 2,090 & 2,230 & V \\
\hline UE-6e (2090-4209 ft) & 365905116012001 & UE-6e & 36.984564 & 116.023170 & 3,938 & 4,209 & 2,090 & 4,209 & $\mathrm{C}, \mathrm{V}$ \\
\hline
\end{tabular}




\begin{tabular}{|c|c|c|c|c|c|c|c|c|c|}
\hline \multirow[b]{2}{*}{$\begin{array}{l}\text { U.S. Geological Survey } \\
\text { well name } \\
\text { (see fig. 2) }\end{array}$} & \multirow[b]{2}{*}{$\begin{array}{c}\text { U.S. Geological Survey } \\
\text { site identification } \\
\text { number }^{1}\end{array}$} & \multirow[b]{2}{*}{ Nevada Test Site hole name ${ }^{2}$} & \multirow[b]{2}{*}{$\begin{array}{l}\text { Latitude } \\
\text { (decimal } \\
\text { degrees) }\end{array}$} & \multirow[b]{2}{*}{$\begin{array}{l}\text { Longitude } \\
\text { (decimal } \\
\text { degrees) }\end{array}$} & \multirow{2}{*}{$\begin{array}{l}\text { Land- } \\
\text { surface } \\
\text { altitude } \\
\text { (feet) }\end{array}$} & \multirow[b]{2}{*}{$\begin{array}{l}\text { Depth } \\
\text { drilled } \\
\text { (feet) }\end{array}$} & \multicolumn{2}{|c|}{ Open interval } & \multirow[b]{2}{*}{$\begin{array}{l}\text { Contributing } \\
\text { units }\end{array}$} \\
\hline & & & & & & & $\begin{array}{l}\text { Depth to } \\
\text { top } \\
\text { (feet) }\end{array}$ & $\begin{array}{l}\text { Depth to } \\
\text { bottom } \\
\text { (feet) }\end{array}$ & \\
\hline UE-7aa & 370412115593601 & UE-7aa & 37.069961 & 115.994173 & 4,259 & 2,154 & 345 & 2,154 & $\mathrm{C}$ \\
\hline UE-7i & 370619116011701 & UE-7i & 37.105281 & 116.022321 & 4,330 & 2,930 & 79 & 2,930 & $\mathrm{C}, \mathrm{V}$ \\
\hline UE-7k & 370453116015201 & UE-7k & 37.081297 & 116.031952 & 4,126 & 2,548 & 74 & 2,548 & $\mathrm{C}, \mathrm{V}$ \\
\hline UE-7nS & 370556116000901 & UE-7nS & 37.098722 & 116.003351 & 4,367 & 2,205 & 1,707 & 2,205 & $\mathrm{C}$ \\
\hline UE-8e (2295 ft) & 371014116051601 & UE-8e/Inst. & 37.170580 & 116.088525 & 4,488 & 2,295 & 71 & 2,121 & $\mathrm{~V}$ \\
\hline UE-8e (2470 ft) & 371014116051602 & UE-8e/Inst. & 37.170580 & 116.088525 & 4,488 & 2,470 & 71 & 2,470 & $\mathrm{C}, \mathrm{V}$ \\
\hline UE-8f & 371022116054901 & UE- $8 f$ & 37.172785 & 116.097712 & 4,560 & 2,248 & -- & -- & -- \\
\hline UE-8n & 371029116053601 & UE-8n & 37.174730 & 116.094331 & 4,549 & 2,372 & 73 & 2,372 & $\mathrm{C}, \mathrm{V}$ \\
\hline UE-10 ITS 1 & 371154116024601 & UE-10 ITS \#1 & 37.198389 & 116.047112 & 4,486 & 2,289 & 82 & 2,289 & $\mathrm{~V}, \mathrm{~S}$ \\
\hline UE-10 ITS 1 (2040 ft) & 371154116024602 & UE-10 ITS \#1 & 37.198389 & 116.047112 & 4,486 & 2,300 & 82 & 2,040 & $\mathrm{~V}$ \\
\hline UE-10 ITS 3 (1926 ft) & 371109116024702 & UE-10 ITS \#3 & 37.185758 & 116.047215 & 4,353 & 2,160 & 85 & 1,926 & $\mathrm{~V}$ \\
\hline UE-10 ITS 3 (2160 ft) & 371109116024701 & UE-10 ITS \#3 & 37.185758 & 116.047215 & 4,353 & 2,160 & 84 & 2,160 & $\mathrm{C}, \mathrm{V}$ \\
\hline UE-10 ITS 5 & 371155116031401 & UE-10 ITS \#5/Inst. & 37.198427 & 116.054666 & 4,522 & 2,334 & 89 & 2,334 & $\mathrm{C}, \mathrm{V}$ \\
\hline UE-10 ITS 5 (2180 ft) & 371155116031402 & UE-10 ITS \#5/Inst. & 37.198427 & 116.054666 & 4,522 & 2,350 & 89 & 2,180 & V \\
\hline UE-10aa & 371131116021501 & UE-10aa/Inst. & 37.192025 & 116.038237 & 4,401 & 1,380 & 76 & 1,380 & $S, X$ \\
\hline UE-10bf & 371123116025201 & UE-10bf/Inst. & 37.189744 & 116.048726 & 4,387 & 2,266 & 77 & 2,266 & $\mathrm{C}, \mathrm{V}$ \\
\hline UE-10bf (2144 ft) & 371123116025202 & UE-10bf/Inst. & 37.189744 & 116.048726 & 4,387 & 2,266 & 77 & 2,144 & $\mathrm{~V}$ \\
\hline UE-10j (2232-2297 ft) & 371108116045303 & UE-10j & 37.185477 & 116.082394 & 4,574 & 2,613 & 2,232 & 2,297 & $\mathrm{C}$ \\
\hline UE-10j (2232-2613 ft) & 371108116045302 & UE-10j & 37.185477 & 116.082394 & 4,574 & 2,613 & 2,232 & 2,613 & $\mathrm{C}$ \\
\hline $\mathrm{UE}-10 \mathrm{j}(2380 \mathrm{ft})$ & 371108116045301 & UE-10j & 37.185477 & 116.082394 & 4,574 & 2,380 & 55 & 2,380 & $\mathrm{C}$ \\
\hline UE-14a & 365550116084201 & UE-14a & 36.930502 & 116.145773 & 4,339 & 3,300 & 80 & 3,300 & V \\
\hline UE-14b & 365550116091101 & UE-14b & 36.930538 & 116.153948 & 4,353 & 3,680 & 2,051 & 3,680 & $\mathrm{~V}$ \\
\hline UE-15d WW (1735-6001 ft) & 371230116021500 & UE-15d Water Well & 37.209100 & 116.042271 & 4,586 & 6,001 & 1,735 & 6,001 & $\mathrm{C}, \mathrm{X}$ \\
\hline UE-15d WW (5400-6001 ft) & 371230116021501 & UE-15d Water Well & 37.209100 & 116.042271 & 4,586 & 6,001 & 5,400 & 6,001 & $\mathrm{C}$ \\
\hline UE-15j & 371201115573601 & UE-15j & 37.200354 & 115.960826 & 4,763 & 1,248 & 15 & 1,248 & $\mathrm{X}$ \\
\hline UE-15j A-5 & 371158115574701 & UE-15j A-5 & 37.199420 & 115.964023 & 4,772 & 745 & 6 & 745 & V \\
\hline UE-16d WW & 370412116095101 & UE-16d Eleana Water Well (Sidetrack) & 37.070063 & 116.165158 & 4,684 & 3,000 & 81 & 1,944 & $\mathrm{C}, \mathrm{S}, \mathrm{X}$ \\
\hline UE-16d WW (830 ft) & 370406116095600 & UE-16d Eleana Water Well (Sidetrack) & 37.070063 & 116.165158 & 4,684 & 830 & 81 & 830 & C, S, X \\
\hline UE-16d WW (2117-2293 ft) & 370412116095102 & UE-16d Eleana Water Well (Sidetrack) & 37.070063 & 116.165158 & 4,684 & 2,350 & 2,117 & 2,293 & $S, X$ \\
\hline UE-16f (1261 ft) & 370208116092401 & UE-16f Eleana & 37.035635 & 116.157588 & 4,651 & 1,261 & 213 & 1,261 & $X, S$ \\
\hline UE-16f (1479 ft) & 370208116092402 & UE-16f Eleana & 37.035635 & 116.157588 & 4,651 & 1,479 & 1,293 & 1,479 & $\mathrm{X}, \mathrm{S}$ \\
\hline UE-17a & 370425116095801 & UE-17a Eleana & 37.073532 & 116.167108 & 4,696 & 1,214 & 745 & 1,214 & S, $\mathrm{X}$ \\
\hline UE-17c & 370616116090801 & UE-17c Eleana & 37.104527 & 116.152997 & 4,835 & 586 & 38 & 586 & $\mathrm{~F}, \mathrm{~S}$ \\
\hline USGS - Shot Hole & 371205116080201 & USGS Shot Hole & 37.201285 & 116.134647 & 5,065 & 105 & -- & -- & V \\
\hline Whiterock Springs 1 & 371204116075501 & Whiterock Springs-1 & 37.201004 & 116.132933 & 5,065 & 72 & 2 & 72 & V \\
\hline Whiterock Springs 2 & 371210116075001 & Whiterock Springs-2 & 37.202646 & 116.131547 & 5,080 & 84 & -- & -- & $\mathrm{V}$ \\
\hline
\end{tabular}




\begin{tabular}{|c|c|c|c|c|c|c|c|c|c|}
\hline \multirow[b]{2}{*}{$\begin{array}{l}\text { U.S. Geological Survey } \\
\text { well name } \\
\text { (see fig. 2) }\end{array}$} & \multirow[b]{2}{*}{$\begin{array}{c}\text { U.S. Geological Survey } \\
\text { site identification } \\
\text { number }\end{array}$} & \multirow[b]{2}{*}{ Nevada Test Site hole name ${ }^{2}$} & \multirow[b]{2}{*}{$\begin{array}{l}\text { Latitude } \\
\text { (decimal } \\
\text { degrees) }\end{array}$} & \multirow[b]{2}{*}{$\begin{array}{l}\text { Longitude } \\
\text { (decimal } \\
\text { degrees) }\end{array}$} & \multirow[b]{2}{*}{$\begin{array}{l}\text { Land- } \\
\text { surface } \\
\text { altitude } \\
\text { (feet) }\end{array}$} & \multirow[b]{2}{*}{$\begin{array}{c}\text { Depth } \\
\text { drilled } \\
\text { (feet) }\end{array}$} & \multicolumn{2}{|c|}{ Open interval } & \multirow[b]{2}{*}{$\begin{array}{l}\text { Contributing } \\
\text { units }\end{array}$} \\
\hline & & & & & & & $\begin{array}{l}\text { Depth to } \\
\text { top } \\
\text { (feet) }\end{array}$ & $\begin{array}{l}\text { Depth to } \\
\text { bottom } \\
\text { (feet) }\end{array}$ & \\
\hline Whiterock Springs 3 & 371158116075501 & Whiterock Springs-3 & 37.199354 & 116.132944 & 5,030 & 41 & -- & -- & V \\
\hline Whiterock Springs 3A & 371159116075201 & Whiterock Springs-3A & 37.199624 & 116.131911 & 4,995 & 10 & -- & -- & $\mathrm{V}$ \\
\hline Whiterock Springs 4 & 371148116074801 & Whiterock Springs-4 & 37.196599 & 116.130902 & 4,959 & 71 & -- & -- & V \\
\hline WW-2 (2045 ft) & 370958116051501 & Water Well 2 [USGS HTH-2] & 37.166185 & 116.088494 & 4,470 & 2,045 & 1,465 & 2,045 & $\mathrm{~V}$ \\
\hline WW-2 (2535 ft) & 370958116051503 & Water Well 2 [USGS HTH-2] & 37.166185 & 116.088494 & 4,470 & 2,535 & 2,121 & 2,535 & $\mathrm{~V}$ \\
\hline WW-2 (2896 ft) & 370958116051508 & Water Well 2 [USGS HTH-2] & 37.166185 & 116.088494 & 4,470 & 2,896 & 2,550 & 2,896 & $\mathrm{C}$ \\
\hline WW-2 (3422ft) & 370958116051512 & Water Well 2 [USGS HTH-2] & 37.166185 & 116.088494 & 4,470 & 3,422 & 2,700 & 3,412 & $\mathrm{C}$ \\
\hline WW-2 (3422 ft, uncased) & 370958116051511 & Water Well 2 [USGS HTH-2] & 37.166185 & 116.088494 & 4,470 & 3,422 & 2,550 & 3,422 & $\mathrm{C}$ \\
\hline WW-3 (1575ft) & 365942116032900 & Well 3 Water Well & 36.995183 & 116.058828 & 3,969 & 1,575 & 1,209 & 1,575 & $\mathrm{~F},(\mathrm{~V})$ \\
\hline WW-3 (1800 ft) & 365942116032901 & Well 3 Water Well & 36.995183 & 116.058828 & 3,969 & 1,800 & 1,209 & 1,800 & $\mathrm{~F}, \mathrm{~V}$ \\
\hline WW-A (1730 ft) & 370142116021100 & USGS Water Well A & 37.036828 & 116.037107 & 4,006 & 1,730 & 1,555 & 1,730 & $\mathrm{~F}$ \\
\hline WW-A (1870 ft) & 370142116021101 & USGS Water Well A & 37.036828 & 116.037107 & 4,006 & 1,870 & 1,555 & 1,870 & $\mathrm{~F}$ \\
\hline WW-C (recompleted) & 365508116003502 & USGS Water Well C & 36.918798 & 116.010513 & 3,924 & 1,701 & 1,373 & 1,701 & $\mathrm{C}$ \\
\hline WW-C (1373-1701 ft) & 365508116003501 & USGS Water Well C & 36.918798 & 116.010513 & 3,924 & 1,701 & 1,373 & 1,701 & $\mathrm{C}$ \\
\hline WW-C-1 & 365500116003901 & Water Well C-1 [U-6 Well D] & 36.918600 & 116.010275 & 3,924 & 1,707 & 914 & 1,707 & $\mathrm{C}$ \\
\hline
\end{tabular}

${ }^{1}$ The U.S. Geological Survey site identification is based on the latitude-longitude grid. Each site is identified by a unique 15-digit number. The first six digits denote degrees, minutes, and seconds of latitude; the next seven digits denote degrees, minutes, and seconds of longitude; and the last two digits are the sequence number of the well or test hole within the 1-second grid of latitude and longitude. The assigned number is retained as a permanent identifier even if a more precise latitude and longitude are later determined. To determine the geographic location of a well or test hole, the latitude and longitude coordinates should be used rather than the site identifier.

${ }^{2}$ Official Nevada Test Site (NTS) hole names are assigned to test holes according to the type of hole drilled, site location (NTS area number), and sequence code for consecutive order in which the hole was drilled or redrilled. Most of the holes drilled on the NTS begin with the letter "U." Exploratory holes, drilled to assess material properties within a defined area, are designated with an "E" following the "U." The "U" or "UE" are followed by a dash (-), NTS area number, and sequence code (letters "a-z, aa-az, ba-bz, ..., za-zz"). The suffix "PS" indicates a post-shot hole, the suffix "Inst.," indicates an instrumented hole, the suffix "\#” followed by a number indicates a satellite hole, and "HTH" indicates a hydrologic test hole. Exceptions to the standard naming convention are wells beginning with "ER," which indicates a well drilled for the Environmental Restoration Program. 
A single number in the parenthetical expression refers to the depth of the well; two numbers separated by a dash refer to the depth of the top and bottom of the open interval in a well. Table 1 lists all 216 wells with water-level measurements in Yucca Flat; figure 2 shows the location of the boreholes where these wells are completed.

Periodic water-level measurements were made manually by the USGS using calibrated electric-cable units (also known as iron-horse and wire-line devices), calibrated electric tapes, or rarely, a steel tape (Garber and Koopman, 1968). Most measurements prior to 1996 were made with an electric-cable unit, whereas, more recent measurements typically were made using electric tapes. The tapes and cable units are calibrated annually at different water-level depths with a USGS 2,000-ft steel reference tape. At the time of measurement, a correction factor is applied to the depth-to-water reading based on the annual calibration. Recent measurements generally are considered more accurate $( \pm 0.1 \mathrm{ft})$ than older measurements $( \pm 0.5$ to $1 \mathrm{ft})$.

In addition to the USGS water-level measurements, supplemental water-level measurements from private contractors working at the NTS are stored in the NWIS database. Most of the contractor data collected prior to 1992 were determined from fluid-density geophysical logs, which are considered accurate to 1-2 ft. Recent contractor water-level measurements made for the DOE Environmental Restoration Program used electric tapes. These tapes, which are calibrated annually with the USGS 2,000-ft steel reference tape, are considered accurate to $\pm 0.1 \mathrm{ft}$.

Water-level fluctuations were monitored by the USGS in eight wells in Yucca Flat using pressure transducers and electronic data loggers. Water levels were measured hourly in these wells from 1- to 6-year periods between 1990 and 1998 (fig. 4). The water-level data are maintained in the NWIS database. Transducer data were checked periodically with manual water-level measurements using a calibrated tape. The general procedure used to calibrate the pressure transducers is outlined in Locke and La Camera (2003, p. 16-18).

Additional continuous water-level data, collected by NTS contractors since 1992, are available for many wells. These data were collected for various purposes using pressure transducers and electronic data loggers. The data were used to monitor water levels for aquifer tests and to monitor water levels during or following well construction and development activities. Wells with 1 to 6 months of continuous data through 2003 include ER-2-1 (2079 ft), ER-2-1 (2559 ft), ER-6-1 main (3206 ft), ER-6-1 (piezometer), ER-6-1-1, ER-6-1-2 (1587 ft), ER-6-1-2 (3200 ft), ER-7-1, ER-12-2 (2964-6883 ft), and ER-12-2 (579 ft) (Jeffrey Wurtz, Stoller-Navarro Joint Venture, written commun., 2004).

A systematic quality-assurance review of the NWIS database for the wells in Yucca Flat was done for this study for the period 1951-2003. This included removing or correcting duplicate sites or erroneous water-level data, and adding missing water-level measurements and construction information. A summary of water-level measurements from the 216 wells is listed in table 2. The earliest measurement was made in 1951 and 48 wells were measured in 2003. The shallowest measured depth to water was $8 \mathrm{ft}$ in wells Whiterock Springs 3 and $3 \mathrm{~A}$ and the deepest measured depth to water was $2,762 \mathrm{ft}$ in well ER-12-1 (3309-3414 ft). Water-level depths of greater than $1,500 \mathrm{ft}$ were measured in 149 wells (table 2).

\section{Description of Water-Level Database}

An interpretative database using Microsoft $®$ Access format was constructed that describes the external conditions influencing each water level that was measured in Yucca Flat. The database contains site information for each well, wellconstruction records, borehole lithology and aquifer data, and water-level data (app. 1). Information in this database was derived by merging data sets created for this study with site and water-level data from NWIS. All tables are linked by the USGS well name and site identification number, a unique 15-digit number used to identify the well site (table 1). Several of the tables also are linked by water-level date. The structure of the water-level database is shown in figure 5. An effort was made to maintain a database structure that is consistent with the structure of the NWIS database. For example, the four well-construction tables from NWIS are preserved in the water-level database.

Hydrographs and well locations in Yucca Flat are interactively presented with a Microsoft $₫$ Excel workbook. The workbook is designed to be an easy-to-use tool to obtain a quick understanding of the water-level history for any well in Yucca Flat. It also can be used to filter water-level data by restricting the data to certain wells, dates, or hydrologic conditions.

An example page from the workbook (fig. 6) shows well UE-10bf, which was selected using the Excel built-in AutoFilter. Selected water-level information from the water-level database is shown for this well. Additionally, a short narrative is displayed that discusses the well and hydrograph.

\section{Site, Well-Construction, and Lithology Information}

Site, well-construction, and lithology information for the Yucca Flat water-level wells are stored in NWIS as well as the Access water-level database. This information can be used as supporting data to understand and interpret the water levels and water-level trends.

Site information for the 216 wells in Yucca Flat is stored in four tables in the Access database (fig. 5; app. 1). Basic site data are in the table YF_sitefile. These data include the DOE name for referencing the borehole where a well is completed, location coordinates (latitude/longitude and Universal Transverse Mercator projection), general location information (hydrographic area number, hydrologic unit code, and NTS area number), and land-surface altitude. Landsurface altitudes and dates of surveys are reported for selected 

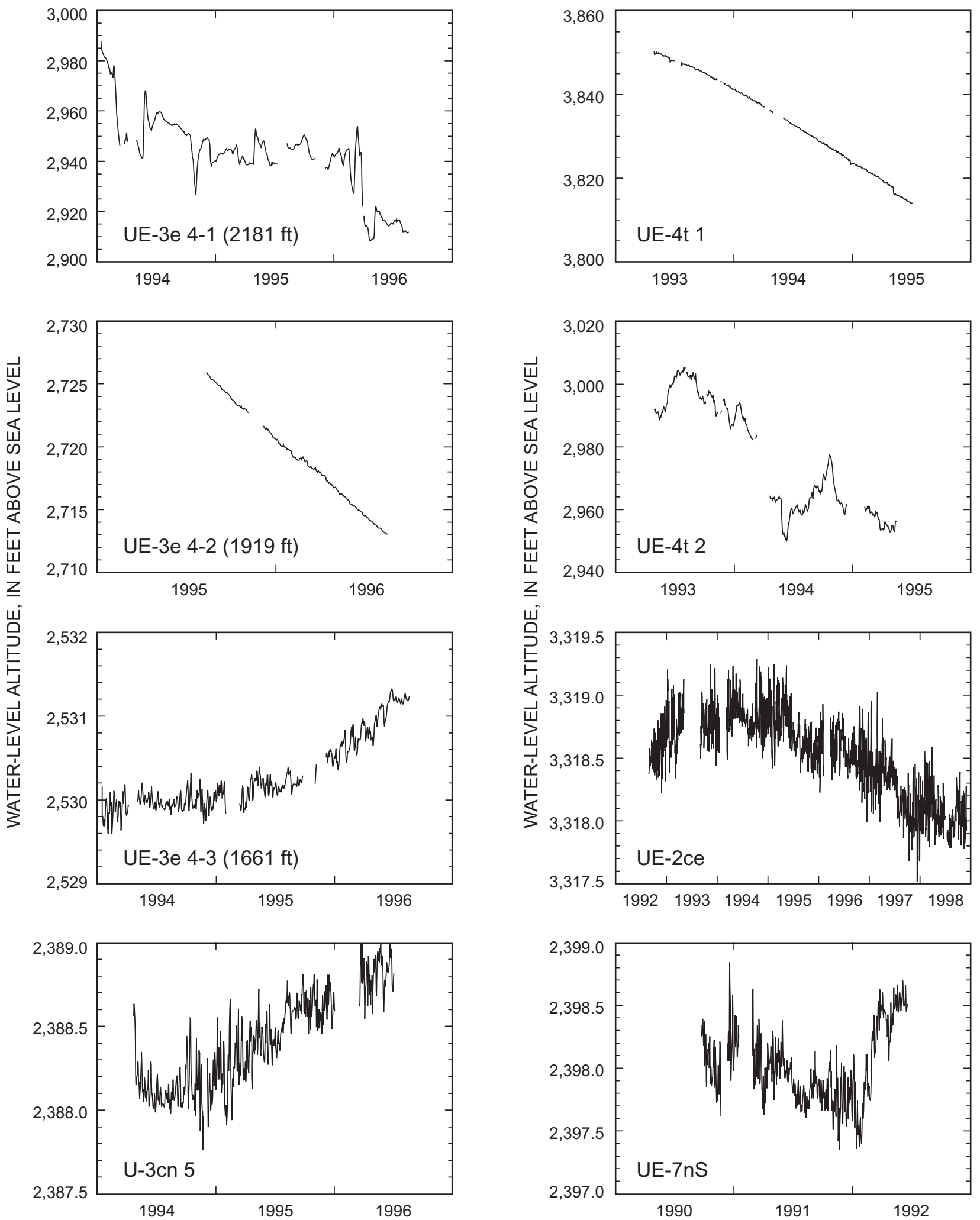

Figure 4. Graphs showing daily mean water levels from wells in Yucca Flat with continuous water levels measured by the U.S. Geological Survey. Horizontal and vertical scales are variable. 
Table 2. Summary of water-level measurements from wells in the Yucca Flat area, Nevada Test Site

Number of measurements: Includes measurements indicating well was dry or obstructed.

Minimum and maximum water level: --, A measurement of the water surface was not made in the well because the well was dry or obstructed.

\begin{tabular}{|c|c|c|c|c|}
\hline \multirow{2}{*}{$\begin{array}{c}\text { U.S. Geological Survey } \\
\text { well name } \\
\text { (see fig. 2) }\end{array}$} & \multicolumn{4}{|c|}{ Water level } \\
\hline & Period of record & $\begin{array}{c}\text { Number of } \\
\text { measurements }\end{array}$ & $\begin{array}{c}\text { Minimum, shallowest } \\
\text { (feet below land surface) }\end{array}$ & $\begin{array}{c}\text { Maximum, deepest } \\
\text { (feet below land surface) }\end{array}$ \\
\hline ER-2-1 (2079 ft) & 2003 & 8 & 1,722 & 1,768 \\
\hline ER-2-1 (2559 ft) & 2003 & 10 & 599 & 677 \\
\hline ER-3-1-1 (deep) & 1994-1995 & 2 & 2,016 & 2,016 \\
\hline ER-3-1-2 (shallow) & 1994-2003 & 37 & 2,015 & 2,017 \\
\hline ER-3-2-1 (deep) & 1994-1995 & 3 & 1,606 & 1,609 \\
\hline ER-3-2-2 (middle) & 1994-2003 & 37 & 1,600 & 1,608 \\
\hline ER-3-2-3 (shallow) & 1994-1995 & 3 & -- & -- \\
\hline ER-6-1 main (2129 ft) & 1992-1994 & 3 & 1,545 & 1,550 \\
\hline ER-6-1 main (2243 ft) & 1995-2003 & 34 & 1,546 & 1,548 \\
\hline ER-6-1 main (3206 ft) & 1994-1995 & 3 & 1,548 & 1,548 \\
\hline ER-6-1 (piezometer) & 1992-2003 & 35 & 1,470 & 1,475 \\
\hline ER-6-1-1 & 1994-2003 & 27 & 1,546 & 1,548 \\
\hline ER-6-1-2 (1587 ft) & 2002-2003 & 10 & 1,471 & 1,472 \\
\hline ER-6-1-2 (3200 ft) & 2002-2003 & 9 & 1,545 & 1,546 \\
\hline ER-6-2 & 1994-2003 & 39 & 1,784 & 1,787 \\
\hline ER-7-1 & 2003 & 3 & 1,853 & 1,853 \\
\hline ER-8-1 & 2003 & 1 & -- & -- \\
\hline ER-12-1 (1641-1846ft) & $1993-2003$ & 36 & 1,526 & 1,542 \\
\hline ER-12-1 (3309-3414ft) & 1992 & 1 & 2,762 & 2,762 \\
\hline ER-12-2 (2964-5203 ft) & 2003 & 8 & 187 & 216 \\
\hline ER-12-2 (2964-6883 ft) & 2003 & 9 & 205 & 818 \\
\hline ER-12-2 (5203-6883 ft) & 2003 & 8 & 186 & 216 \\
\hline ER-12-2 (579 ft) & 2003 & 10 & 414 & 418 \\
\hline ME-1 & 1959-2001 & 4 & 334 & 336 \\
\hline ME-2 & 1959-2001 & 2 & -- & -- \\
\hline ME-3 & 1959-2001 & 12 & 477 & 482 \\
\hline ME-4 & 1959-2001 & 2 & -- & -- \\
\hline TH-9 & 1969 & 1 & 1,785 & 1,785 \\
\hline TW-7 & 1958-2003 & 167 & 1,580 & 1,668 \\
\hline TW-B & 1961-2003 & 111 & 1,503 & 1,509 \\
\hline TW-D & $1961-2003$ & 46 & 1,722 & 1,732 \\
\hline TW-E (1970 ft) & 1960 & 4 & 1,716 & 1,716 \\
\hline TW-E (2430 ft) & 1961 & 5 & 1,731 & 1,732 \\
\hline TW-E (2620 ft) & $1962-2003$ & 12 & 1,769 & 1,788 \\
\hline $\mathrm{U}-2 \mathrm{av}$ & 1969 & 6 & 1,780 & 1,872 \\
\hline U-2az 1 & 1970 & 1 & 1,801 & 1,801 \\
\hline $\mathrm{U}-2 \mathrm{bs}$ & 1971-1972 & 37 & 1,721 & 1,911 \\
\hline U-2bs PS 1DB & 1973-1975 & 12 & 1,940 & 1,975 \\
\hline $\mathrm{U}-2 \mathrm{bt}$ & 1971 & 7 & 1,626 & 1,780 \\
\hline U-2ca 1 & 1965 & 24 & 1,281 & 1,326 \\
\hline $\mathrm{U}-2 \mathrm{df}$ & 1969 & 1 & 1,858 & 1,858 \\
\hline $\mathrm{U}-2 \mathrm{dr}$ & 1972-1974 & 15 & 1,849 & 1,860 \\
\hline U-2eh & 1974 & 2 & 1,870 & 1,898 \\
\hline U-2ei & 1977 & 6 & 1,898 & 1,921 \\
\hline U-2ex & 1982-1983 & 5 & 1,840 & 1,847 \\
\hline $\mathrm{U}-2 \mathrm{gf}$ & 1987 & 13 & 1,769 & 1,779 \\
\hline
\end{tabular}


Table 2. Summary of water-level measurements from wells in the Yucca Flat area, Nevada Test Site-Continued

\begin{tabular}{|c|c|c|c|c|}
\hline \multirow{2}{*}{$\begin{array}{l}\text { U.S. Geological Survey } \\
\text { well name } \\
\text { (see fig. 2) }\end{array}$} & \multicolumn{4}{|c|}{ Water level } \\
\hline & Period of record & $\begin{array}{c}\text { Number of } \\
\text { measurements }\end{array}$ & $\begin{array}{l}\text { Minimum, shallowest } \\
\text { (feet below land surface) }\end{array}$ & $\begin{array}{c}\text { Maximum, deepest } \\
\text { (feet below land surface) }\end{array}$ \\
\hline U-2gg PS E3A & 1995-1996 & 3 & 1,821 & 1,822 \\
\hline $\mathrm{U}-2 \mathrm{gh}$ & 1988-1989 & 21 & 1,572 & 1,578 \\
\hline $\mathrm{U}-2 \mathrm{gk}$ & 1992-2003 & 44 & 1,778 & 1,803 \\
\hline $\mathrm{U}-2 \mathrm{v}$ & 1966 & 1 & 1,825 & 1,825 \\
\hline U-3an 3 & 1963 & 1 & 1,685 & 1,685 \\
\hline $\mathrm{U}-3 \mathrm{cn} 1$ & 1963 & 2 & 1,670 & 1,671 \\
\hline $\mathrm{U}-3 \mathrm{cn} 3$ & 1963 & 3 & 1,672 & 1,683 \\
\hline U-3en 4 HTH & 1963 & 15 & 1,195 & 1,689 \\
\hline U-3en 5 & 1966-2003 & 67 & 1,619 & 1,623 \\
\hline U-3en PS 2 & 1963-1977 & 151 & 1,550 & 1,905 \\
\hline U-3jg & 1972 & 7 & 1,546 & 1,554 \\
\hline U-3jn 1 & 1971 & 3 & 1,644 & 1,649 \\
\hline U-3jq 1 & 1972 & 6 & 1,712 & 1,714 \\
\hline $\mathrm{U}-3 \mathrm{ks}$ & 1977 & 5 & 1,547 & 1,590 \\
\hline U-3kv & 1979-1991 & 27 & 1,532 & 1,536 \\
\hline $\mathrm{U}-3 \mathrm{kz}$ & 1984-1986 & 89 & 1,141 & 2,189 \\
\hline $\mathrm{U}-3 \mathrm{mh}$ & 1986-1987 & 4 & 1,590 & 1,664 \\
\hline $\mathrm{U}-3 \mathrm{mi}$ & $1987-2003$ & 53 & 1,558 & 1,598 \\
\hline $\mathrm{U}-3 \mathrm{mt}$ & 1990-1991 & 7 & 1,537 & 1,538 \\
\hline U-4ak & 1981 & 2 & 1,615 & 1,617 \\
\hline U-4au & 1987-1988 & 16 & 1,638 & 1,644 \\
\hline U-4av & 1990-1991 & 16 & 1,582 & 1,686 \\
\hline U-4r & 1983-1984 & 17 & 1,523 & 2,190 \\
\hline $\mathrm{U}-4 \mathrm{t} 1$ & 1986 & 13 & 1,034 & 1,058 \\
\hline $\mathrm{U}-4 \mathrm{u}(2112 \mathrm{ft})$ & 1987 & 1 & 1,463 & 1,463 \\
\hline U-4u PS 2A & 1990-1998 & 60 & 1,492 & 1,642 \\
\hline U-6e & 1984-1986 & 2 & -- & -- \\
\hline $\mathrm{U}-7 \mathrm{a}$ & 1963 & 4 & 1,812 & 1,868 \\
\hline U-7ad (1853 ft) & 1972 & 28 & 1,810 & 1,850 \\
\hline U-7ad (1965 ft) & 1972 & 3 & 1,806 & 1,820 \\
\hline U-7ae (2056 ft) & 1976 & 3 & 1,786 & 1,802 \\
\hline U-7ag & 1973 & 12 & 1,894 & 1,972 \\
\hline U-7au & 1978 & 1 & 1,603 & 1,603 \\
\hline U-7ba & 1980 & 1 & 1,504 & 1,504 \\
\hline U-7ba PS 1AS & 1994-1996 & 4 & 1,171 & 1,178 \\
\hline $\mathrm{U}-7 \mathrm{bc}$ & 1981 & 4 & 1,744 & 1,855 \\
\hline U-7bd & 1978 & 3 & 1,749 & 1,754 \\
\hline $\mathrm{U}-7 \mathrm{bL}$ & 1985 & 1 & -- & -- \\
\hline $\mathrm{U}-7 \mathrm{bz}(817-2188 \mathrm{ft})$ & 1989-2002 & 3 & 1,658 & 1,659 \\
\hline U-7ca & 1985-1988 & 16 & 1,702 & 1,707 \\
\hline $\mathrm{U}-7 \mathrm{cb}$ & 1986-1991 & 54 & 1,784 & 1,798 \\
\hline $\mathrm{U}-7 \mathrm{cc}$ & 1988-2002 & 7 & 1,577 & 1,581 \\
\hline U-7cd & $1992-2003$ & 58 & 1,426 & 1,614 \\
\hline U-7cd 1 & 1992-1993 & 16 & 1,419 & 1,675 \\
\hline
\end{tabular}


Table 2. Summary of water-level measurements from wells in the Yucca Flat area, Nevada Test Site-Continued

\begin{tabular}{|c|c|c|c|c|}
\hline \multirow{2}{*}{$\begin{array}{c}\text { U.S. Geological Survey } \\
\text { well name } \\
\text { (see fig. 2) }\end{array}$} & \multicolumn{4}{|c|}{ Water level } \\
\hline & Period of record & $\begin{array}{c}\text { Number of } \\
\text { measurements }\end{array}$ & $\begin{array}{c}\text { Minimum, shallowest } \\
\text { (feet below land surface) }\end{array}$ & $\begin{array}{c}\text { Maximum, deepest } \\
\text { (feet below land surface) }\end{array}$ \\
\hline $\mathrm{U}-8 \mathrm{j}$ & 1983-1984 & 6 & 1,768 & 1,867 \\
\hline $\mathrm{U}-8 \mathrm{n}$ & 1984-1988 & 5 & 1,772 & 1,843 \\
\hline U-9 ITS UE-S-25 & 1971 & 3 & 1,793 & 1,794 \\
\hline U-9ct & 1981-2002 & 4 & 1,677 & 1,682 \\
\hline U-10k 1 & 1964-1965 & 6 & 1,858 & 1,867 \\
\hline U-10L 1 & 1964-1997 & 7 & 1,840 & 1,860 \\
\hline U-15a 31 (1200 ft) & 1962 & 1 & 187 & 187 \\
\hline U-15k Test Hole & 1997-2003 & 20 & 655 & 787 \\
\hline UE-1d & 1964-1967 & 2 & 536 & 536 \\
\hline UE-1f & 1964-1977 & 2 & 628 & 628 \\
\hline UE-1h & $1982-2003$ & 33 & 1,555 & 1,559 \\
\hline UE- $1 \mathrm{j}$ & 1968-1988 & 2 & 1,538 & 1,538 \\
\hline UE-1k & 1969-1973 & 5 & 1,603 & 1,605 \\
\hline UE-1L (5339 ft) & 1976-1977 & 10 & 504 & 508 \\
\hline UE-1L (recompleted) & $1978-2003$ & 38 & 499 & 520 \\
\hline UE-1q $(2437 \mathrm{ft})$ & 1980-1991 & 12 & 1,553 & 1,569 \\
\hline UE-1q (2600 ft) & 1992-2003 & 41 & 1,655 & 1,656 \\
\hline UE-1r WW & 1984 & 3 & 1,626 & 1,769 \\
\hline UE-2b & 1968 & 1 & 1,888 & 1,888 \\
\hline UE-2ce & $1977-2003$ & 194 & 1,398 & 1,478 \\
\hline UE-2dj & 1971 & 6 & 1,878 & 1,896 \\
\hline $\mathrm{UE}-2 \mathrm{fb}$ & 1977 & 10 & 1,721 & 1,772 \\
\hline UE-2s & 1964 & 23 & 1,825 & 1,944 \\
\hline UE-3e (1707ft) & 1986 & 4 & 1,555 & 1,557 \\
\hline UE-3e (2105 ft) & 1986 & 15 & 1,488 & 1,968 \\
\hline UE-3e $(2110 \mathrm{ft})$ & 1986 & 5 & 1,512 & 1,543 \\
\hline UE-3e $(2118-2510 \mathrm{ft})$ & 1986 & 22 & 838 & 1,649 \\
\hline UE-3e $(2410 \mathrm{ft})$ & 1986 & 30 & 1,540 & 1,826 \\
\hline UE-3e $(2510 \mathrm{ft})$ & 1986 & 2 & 1,542 & 1,609 \\
\hline UE-3e 2 (2372 ft) & $1987-1988$ & 16 & 517 & 673 \\
\hline UE-3e 3 (2221 ft) & 1988 & 1 & -- & -- \\
\hline UE-3e 4 (2300 ft) & 1990 & 6 & 1,537 & 1,991 \\
\hline UE-3e 4-1 (2181 ft) & $1990-2003$ & 99 & 1,024 & 1,304 \\
\hline UE-3e 4-2 (1919 ft) & $1990-2003$ & 109 & 1,234 & 1,420 \\
\hline UE-3e 4-3 (1661 ft) & 1990-2003 & 98 & 1,548 & 1,560 \\
\hline
\end{tabular}


Table 2. Summary of water-level measurements from wells in the Yucca Flat area, Nevada Test Site-Continued

\begin{tabular}{|c|c|c|c|c|}
\hline \multirow{2}{*}{$\begin{array}{l}\text { U.S. Geological Survey } \\
\text { well name } \\
\text { (see fig. 2) }\end{array}$} & \multicolumn{4}{|c|}{ Water level } \\
\hline & Period of record & $\begin{array}{l}\text { Number of } \\
\text { measurements }\end{array}$ & $\begin{array}{l}\text { Minimum, shallowest } \\
\text { (feet below land surface) }\end{array}$ & $\begin{array}{c}\text { Maximum, deepest } \\
\text { (feet below land surface) }\end{array}$ \\
\hline UE-3mf (119-1692 ft) & 1987 & 5 & 1,482 & 1,546 \\
\hline UE-3mf (119-1894ft) & 1986 & 22 & 1,428 & 1,477 \\
\hline UE-3mf $(1692-2395 \mathrm{ft})$ & 1987 & 6 & 1,414 & 1,458 \\
\hline UE-3mf $(1700 \mathrm{ft})$ & 1986 & 4 & 1,601 & 1,630 \\
\hline UE-3mf (1894-2395 ft) & 1986 & 34 & 1,359 & 1,590 \\
\hline UE-3mf $(2100 \mathrm{ft})$ & 1986 & 25 & 1,440 & 2,099 \\
\hline UE-4a (2655 ft) & $1961-1963$ & 16 & 1,461 & 1,620 \\
\hline UE-4a (3028 ft) & 1961 & 1 & 1,740 & 1,740 \\
\hline UE-4aa & 1973 & 3 & 1,219 & 1,219 \\
\hline UE-4ab (2396 ft) & 1973-1982 & 9 & 1,624 & 1,807 \\
\hline UE-4ab (2650 ft) & 1973 & 1 & 1,874 & 1,874 \\
\hline UE-4ac (1522 ft) & 1983 & 1 & -- & -- \\
\hline UE-4ac (1677 ft) & 1974 & 1 & -- & -- \\
\hline UE-4ae (2290 ft) & 1974-1981 & 4 & 1,620 & 1,634 \\
\hline UE-4ae (2457 ft) & 1974 & 1 & 1,628 & 1,628 \\
\hline UE-4ah & 1978-1979 & 8 & 1,543 & 1,656 \\
\hline UE-4av (1724-2815 ft) & 1989-1990 & 22 & 1,626 & 2,211 \\
\hline UE-4av (1758 ft) & 1989 & 5 & 1,564 & 1,728 \\
\hline UE-4av (2815 ft) & 1990-1991 & 4 & 1,564 & 1,571 \\
\hline UE-4t $(1619-1721 \mathrm{ft})$ & 1989-1990 & 7 & 865 & 888 \\
\hline UE-4t (1701 ft) & 1987 & 1 & 1,600 & 1,600 \\
\hline UE-4t (1947 ft) & 1987 & 6 & 1,068 & 1,428 \\
\hline UE-4t (2413 ft) & 1987-1989 & 33 & 867 & 1,746 \\
\hline UE-4t 1 (1906-2010 ft) & 1990-2003 & 114 & 288 & 493 \\
\hline UE-4t 2 (1564-1754 ft) & 1990-2003 & 98 & 361 & 1,196 \\
\hline UE-6d & $1968-2003$ & 51 & 1,514 & 1,528 \\
\hline UE-6e (2090-2230 ft) & 1994-2003 & 38 & 1,509 & 1,514 \\
\hline UE-6e (2090-4209ft) & 1980-1992 & 15 & 1,507 & 1,510 \\
\hline UE-7aa & 1969-1971 & 16 & 1,860 & 2,114 \\
\hline UE-7i & 1983-1984 & 3 & 1,783 & 1,788 \\
\hline UE-7k & 1981-1997 & 2 & -- & -- \\
\hline UE-7nS & 1976-2003 & 148 & 1,959 & 1,976 \\
\hline UE-8e (2295 ft) & 1970-1972 & 6 & 1,904 & 2,006 \\
\hline UE-8e (2470 ft) & 1973-1976 & 6 & 1,910 & 2,060 \\
\hline UE-8f & 1997 & 1 & -- & -- \\
\hline UE-8n & 1988 & 2 & -- & -- \\
\hline UE-10 ITS 1 & 1969-1972 & 16 & 1,213 & 1,238 \\
\hline UE-10 ITS 1 (2040 ft) & 1972-1986 & 7 & 1,221 & 1,250 \\
\hline UE-10 ITS 3 (1926ft) & 1973-1989 & 12 & 1,849 & 1,860 \\
\hline UE-10 ITS 3 (2160 ft) & 1969-1972 & 16 & 1,867 & 2,023 \\
\hline UE-10 ITS 5 & 1970-1972 & 6 & 2,034 & 2,071 \\
\hline UE-10 ITS 5 (2180 ft) & 1973-1977 & 4 & 1,985 & 1,990 \\
\hline UE-10aa & 1973-1980 & 4 & 1,134 & 1,151 \\
\hline UE-10bf & 1978 & 8 & 1,890 & 1,911 \\
\hline
\end{tabular}


Table 2. Summary of water-level measurements from wells in the Yucca Flat area, Nevada Test Site-Continued

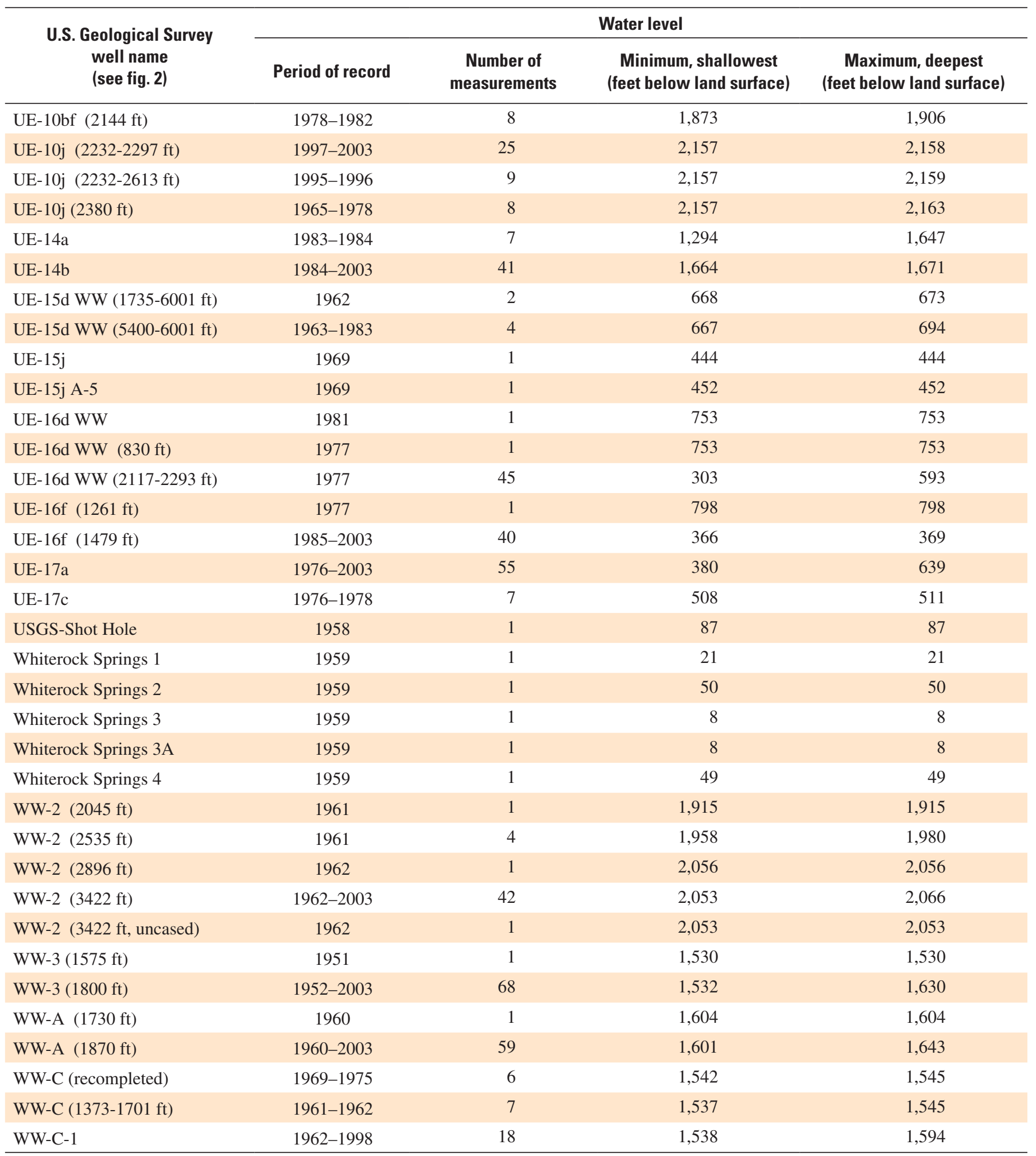




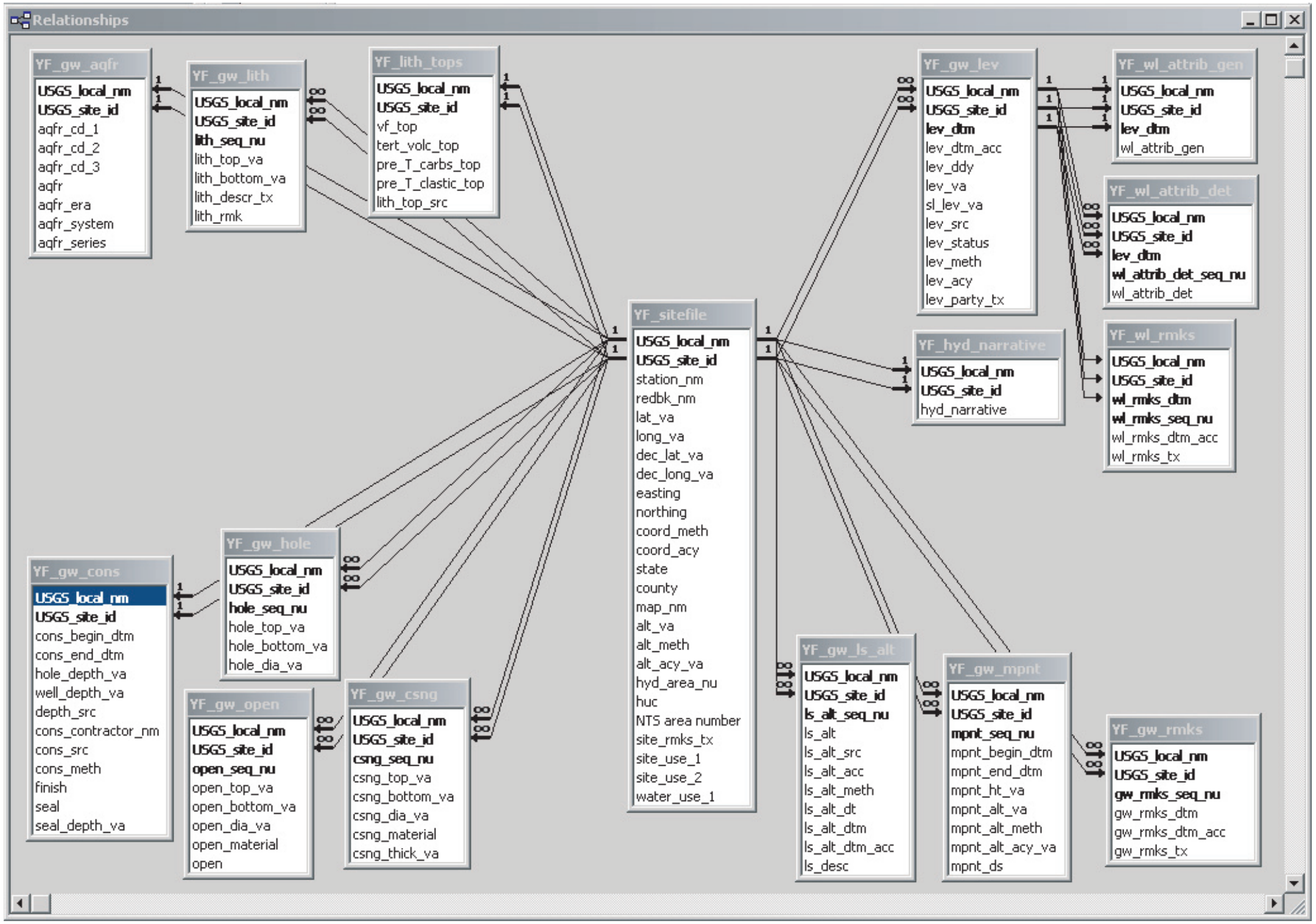




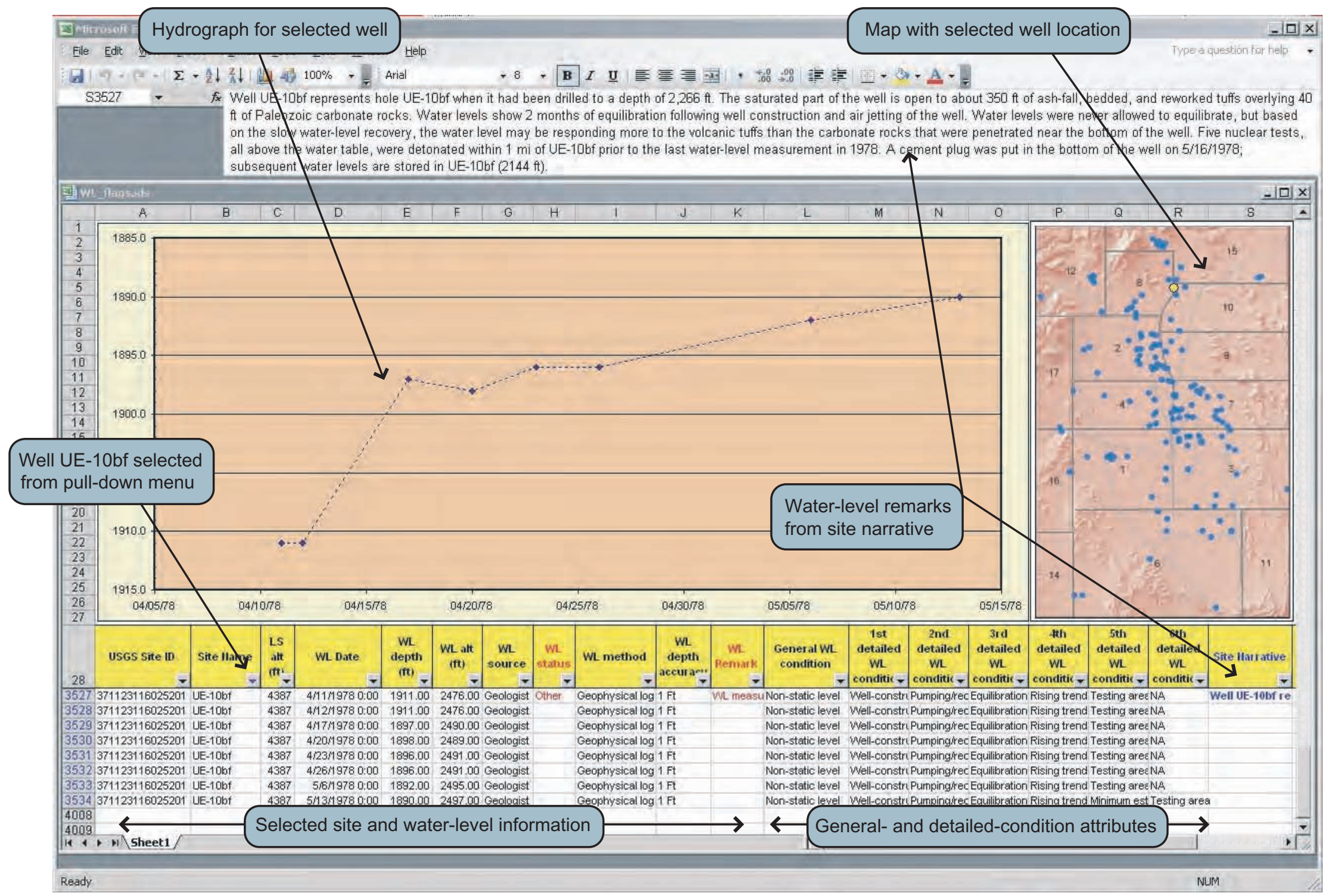

Figure 6. Diagram example of water-level output from Microsoft $\AA^{\circledR}$ Excel workbook. 
wells in the table YF_gw_ls_alt. A third table, YF_gw_mpnt, contains fields that describe the measuring point for many of the wells that are actively measured as part of the DOE NTS water-level network. The last table, YF_gw_rmks, has miscellaneous remarks related to the site, well, or water levels. These remarks are derived from a variety of sources including published reports, drilling records, or field notes.

Well-construction records are stored in four tables in the Access database (fig. 5; app. 1). General construction information, such as construction dates, borehole and well depth, and construction method, are in the table YF_gw_cons. The remaining three tables, YF_gw_hole, YF_gw_csng, and YF_gw_open, provide information on borehole diameter, casing, and open intervals for each well.

Lithology information for each borehole and names of lithologic unit(s) contributing water to each well are stored in three tables in the Access database (fig. 5; app. 1). Detailed lithologic descriptions of cuttings or cores for most boreholes are in the table YF_gw_lith. These original descriptions were written by many different geologists and workers over the past 50 years and compiled primarily by H.R. Covington and D.B. Wood of the USGS. The second Access table, YF_lith_tops, provides the depths to the top of the valley fill, Tertiary volcanic rocks, pre-Tertiary carbonate rocks, and pre-Tertiary clastic rocks for each well in the database. The third table, YF_gw_aqfr, identifies the aquifers or lithologic units contributing water to each well. The designations for aquifers or water-bearing units in this table are lithostratigraphic based rather than hydrostratigraphic based, as is commonly used for the NTS (Laczniak and others, 1996, table 1).

\section{Water-Level Data}

Water-level measurement source, method, and accuracy, as well as hydrologic conditions during water-level measurements, are attributed in the Access database. Interpretations for individual water-level measurements and for the period of record from a well have been incorporated into the attributes. Abrupt water-level changes and long-term water-level declines are examples of typical phenomena that were interpreted.

Hydrologic-condition attributes were used to describe the state of each water level that was measured in Yucca Flat. They also describe the external factors that caused a water level to be at the depth reported. Some of the attributes are subjective interpretations made by the author. Hydrologic-condition attributes were categorized as either general or detailed (table 3). General-condition attributes describe the state of a water level. Examples are steady state, transient, nonstatic level, and localized conditions. Detailed-condition attributes can either denote the factor affecting a water level or describe the effect that a factor has on a water level. Factors affecting water levels include nuclear tests, climate, pumping, and recent well construction. Water-level effects include abrupt change, anomalous-high, equilibration, and rising trend. One general-condition attribute and 0-6 detailed-condition attributes were assigned to each water-level measurement in Yucca Flat.

An example of how water levels from well TW-7 were attributed is shown in figure 7 . In this example, initial waterlevel measurements were relatively consistent and considered representative of regional steady-state conditions. However, after the Aardvark nuclear test in 1962, localized hydrologic conditions prevailed as water levels were altered by multiple underground nuclear tests that caused abrupt rises in water levels. Subsequent to each rise, a declining trend occurred as water levels equilibrated from the nuclear test.

The water-level history of each well also is documented as a narrative. The narrative consists of comments or explanations about the well or about one or more measured water levels in the well. An interpretation of the hydrograph and its hydrologic significance usually is provided. The narrative may include information about the open interval, testing done in the well, the well productivity, specific influences near the well that may have affected water levels (such as a nuclear test), and any other details that may provide insight into the condition of the water levels. Most of the basic information included in the narrative was derived from published reports or USGS data files archived in Henderson, Nev.

Data pertaining to water-level measurements in Yucca Flat are stored in five tables in the Access database (fig. 5; app. 1). The table YF_gw_lev contains the basic data pertaining to the water-level measurement. These data include the water-level date, depth, source, status, method, and accuracy. The accuracy pertains to the depth-to-water measurement and not the water-level altitude. The table YF_wl_rmks contains remarks related to specific water-level measurements. The general- and detailed-condition attributes for each water-level measurement are stored in the Access tables YF_wl_attrib_ gen and YF_wl_attrib_det. The hydrograph narratives are stored in the table YF_hyd_narrative.

\section{Borehole Deviation}

Estimates of borehole deviation were available for many of the boreholes used in this study. In most cases, deviation was minimal and bottom-hole vertical corrections were less than $0.5 \mathrm{ft}$. As a general rule, water levels were not corrected for borehole deviation unless the correction was greater than $0.5 \mathrm{ft}$. Corrections smaller than $0.5 \mathrm{ft}$ were not applied to water levels because the uncertainty in the deviation correction may be as great or greater than the magnitude of the correction.

Water-level corrections for selected depth intervals (table 4) were developed using linear equations based on cumulative measured borehole deviations. Within the selected depth interval, the angle of deviation is assumed constant. The true vertical water-level depth was determined by substituting the measured water-level depth, and measured and true vertical borehole interval depths from a deviation survey into a linear 
Table 3. Description of general- and detailed-condition attributes assigned to water levels in Yucca Flat

Number of water levels: Number of water levels in Yucca Flat assigned with this attribute. Each water level was assigned only one general-condition attribute but may have multiple detailed-condition attributes.

\begin{tabular}{|c|c|c|}
\hline Attribute name & Description & $\begin{array}{c}\text { Number } \\
\text { of water } \\
\text { levels }\end{array}$ \\
\hline Insufficient data & Water level does not have sufficient supporting information to determine its general condition. & 63 \\
\hline None & Hole is dry or obstructed, or site was visited but water level was not measured. & 53 \\
\hline Nonstatic level & $\begin{array}{l}\text { Water level is affected by activities in the well such as aquifer testing, well construction, or } \\
\text { pumping. Water level does not represent conditions within the aquifer. }\end{array}$ & 1,166 \\
\hline Suspect & Water level is suspect or in error, and cannot be attributed to any known hydrologic cause. & 161 \\
\hline Transient-REGIONAL & Water level represents changes from pumping in the regional ground-water flow system. & 128 \\
\hline
\end{tabular}

\section{Detailed-condition attribute}

Abrupt change

Anomalous - high

Anomalous - low

Borehole deviation

Consistent

Declining trend

Dry

Elevated

Equilibration

Erratic/Unstable

Injection/recovery

Limited data
Water level rapidly shifted or changed from previous measurements.

Water-level altitude is unusually high relative to other measurements at the site or at nearby sites.

858

Water-level altitude is unusually low relative to other measurements at the site or at nearby sites.

Water level is corrected for borehole deviation.

Water level appears to be part of a reasonably consistent trend representative of general waterlevel conditions in the area.

Water level appears to be part of a discernable, overall downward trend. Possible causes include nearby pumping, decreased recharge, equilibration following drilling, or depressurization after a nuclear test.

Site was dry at time of measurement.

Water level is elevated appreciably above the regional ground-water system, probably because of natural conditions.

Water level appears to be part of a discernable, overall trend that is approaching an equilibrium level, either higher or lower than the initial measurement. Equilibration commonly occurs following well construction, pumping, or nearby nuclear testing.

Water level is erratic and unstable.

Water level appears to be affected by recent injection of water, mud, or other fluid into the well or hole.

Water level is one of a limited number. Therefore general-condition attribute assigned to water level is tentative. 
Table 3. Description of general- and detailed-condition attributes assigned to water levels in Yucca Flat-Continued

\begin{tabular}{|c|c|c|}
\hline Attribute name & Description & $\begin{array}{c}\text { Number } \\
\text { of water } \\
\text { levels }\end{array}$ \\
\hline Maximum estimate & $\begin{array}{l}\text { Water level or depth to bottom of hole (where hole is dry) represents a maximum estimate of the } \\
\text { equilibrated water-level altitude in the monitored hydrologic unit. }\end{array}$ & 10 \\
\hline Nearby drilling effect & Water level is affected by drilling activities in a nearby hole. & 24 \\
\hline Nuclear-test effect & Water level appears to be or is suspected of being affected by nearby nuclear tests. & 1,406 \\
\hline Pumping/recovery & $\begin{array}{l}\text { Water level appears to be responding to current or past pumping at the site or at a nearby site. If } \\
\text { water-level measurement is missing, well was actively pumping at time of measurement. }\end{array}$ & 529 \\
\hline Rising trend & $\begin{array}{l}\text { Water level appears to be part of a discernable, overall rising trend. Possible causes include a } \\
\text { decrease in nearby pumping, equilibration following drilling, and above-normal precipitation. }\end{array}$ & 1,602 \\
\hline Suspected perched water & Water level appears to represent perched-water conditions. & 21 \\
\hline Testing area & Site is within 1 mile of one or more underground nuclear tests. Water level possibly is affected. & 1,817 \\
\hline Undeveloped & $\begin{array}{l}\text { Water level may not accurately represent hydrologic conditions because of insufficient or no well } \\
\text { development. }\end{array}$ & 94 \\
\hline
\end{tabular}




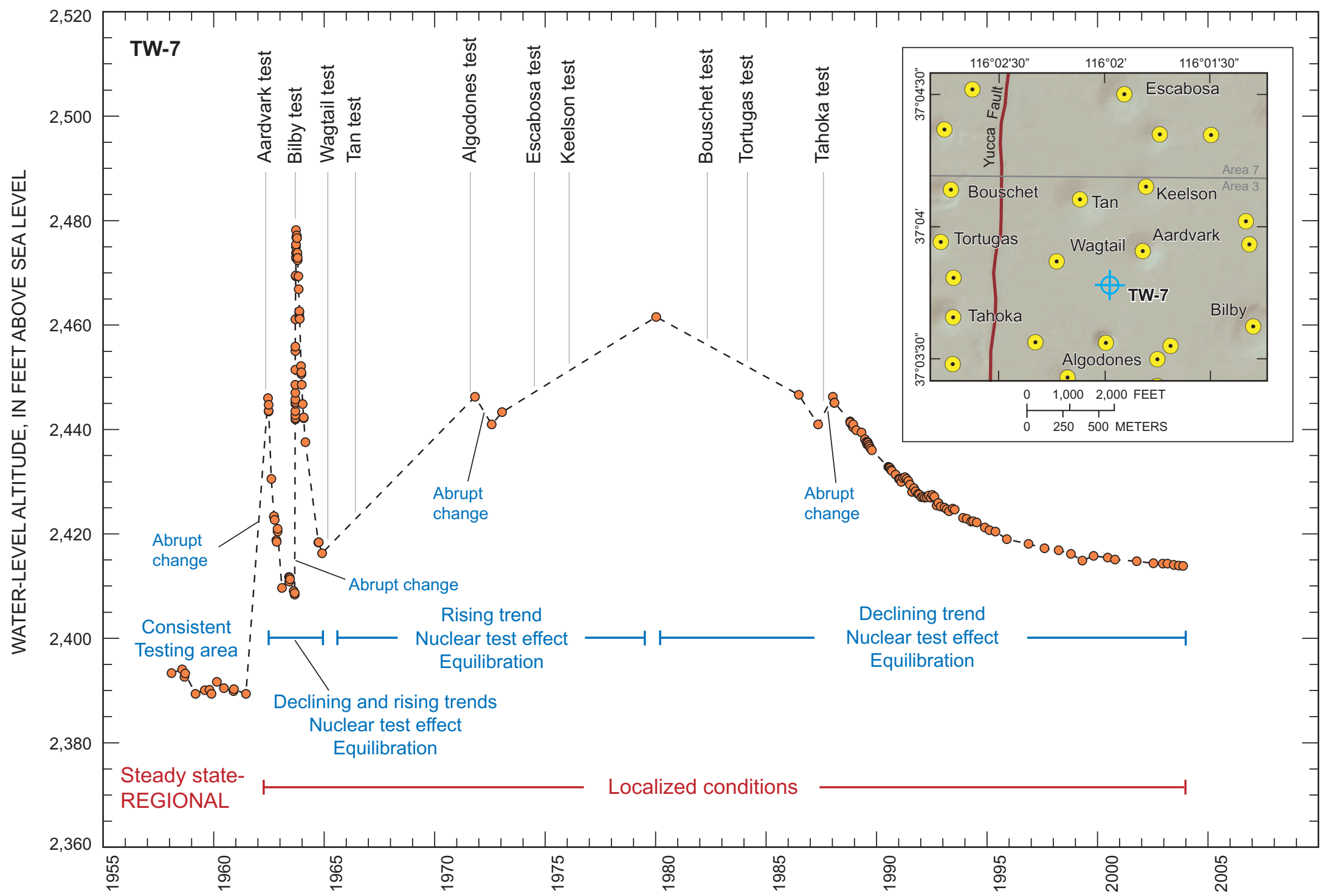

Figure 7. Hydrograph of well TW-7 showing (1) example of general (red) and detailed (blue) condition attributes that were assigned to water levels, and (2) relation between water levels and nearby underground nuclear tests. Map inset shows all nearby nuclear tests. The water-level attributes for this well are stored in the Microsoft ${ }^{\circledR}$ Access database accompanying this report. 
Table 4. Water-level corrections for borehole deviations in selected boreholes in Yucca Flat

Source of data: BDS, borehole-deviation survey run along length of borehole. Slant hole, the angle of the borehole, which was assumed to be constant along its length, was obtained from a drilling report or well diagram.

Depth interval over which correction applies: Interval, which bounds the minimum and maximum depths of historic water-level measurements, was used to determine equation for borehole-deviation correction.

Equation used for correction: $\mathrm{V}_{\mathrm{d}}$, corrected vertical water-level depth; $\mathrm{M}_{\mathrm{d}}$, measured water-level depth in borehole.

Water-level mean measured depth: Mean measured depth to water in borehole before borehole-deviation correction was applied. ,-- no water level measured for depth interval.

Water-level adjustment: Amount of adjustment subtracted from mean measured water level $\left(\mathrm{M}_{\mathrm{d}}\right)$ to obtain corrected mean vertical water-level measurement $\left(\mathrm{V}_{\mathrm{d}}\right) ;--$, no adjustment applied.

\begin{tabular}{|c|c|c|c|c|c|}
\hline \multirow{2}{*}{$\begin{array}{l}\text { Borehole name } \\
\text { (see fig. 2) }\end{array}$} & \multirow{2}{*}{$\begin{array}{c}\text { Source of } \\
\text { data }\end{array}$} & \multirow{2}{*}{$\begin{array}{l}\text { Depth interval } \\
\text { over which } \\
\text { correction ap- } \\
\text { plies, in feet }\end{array}$} & \multirow{2}{*}{ Equation used for correction } & \multicolumn{2}{|c|}{ Water level } \\
\hline & & & & $\begin{array}{l}\text { Mean measured } \\
\text { depth, in feet }\end{array}$ & $\begin{array}{l}\text { Adjustment, } \\
\text { in feet }\end{array}$ \\
\hline ER-6-2 & BDS & $1,701-1,877$ & $\mathrm{~V}_{\mathrm{d}}=\mathrm{M}_{\mathrm{d}} * 0.99771+2.12$ & $1,787.2$ & 2.0 \\
\hline ME-2 & Slant hole & $0-274$ & $\mathrm{~V}_{\mathrm{d}}=\mathrm{M}_{\mathrm{d}} * 0.6984$ & 152.0 & 45.8 \\
\hline U-2bs PS 1DB & Slant hole & $1,838-2,188$ & $\mathrm{~V}_{\mathrm{d}}=\mathrm{M}_{\mathrm{d}} * 0.8038+239.62$ & $2,138.0$ & 179.9 \\
\hline U-2gg PS E3A & Slant hole & $0-2,060$ & $\mathrm{~V}_{\mathrm{d}}=\mathrm{M}_{\mathrm{d}} * 0.95106$ & $1,915.0$ & 93.7 \\
\hline U-3en 5 & BDS & $1,429-1,970$ & $\mathrm{~V}_{\mathrm{d}}=\mathrm{M}_{\mathrm{d}} * 0.9954+5.42$ & $1,622.6$ & 2.0 \\
\hline U-4u PS 2A & BDS & $1,485-1,665$ & $\mathrm{~V}_{\mathrm{d}}=\mathrm{M}_{\mathrm{d}} * 0.94500-4.46$ & $1,702.3$ & 98.1 \\
\hline U-7ba PS 1AS & $\mathrm{BDS}^{1}$ & $926-1,476$ & $\mathrm{~V}_{\mathrm{d}}=\mathrm{M}_{\mathrm{d}} * 0.92489+24.99$ & $1,242.9$ & 68.4 \\
\hline UE-10j² & BDS & $2,100-2,200$ & $\mathrm{~V}_{\mathrm{d}}=\mathrm{M}_{\mathrm{d}} * 0.9927+13.32$ & $2,160.2$ & 2.4 \\
\hline $\mathrm{WW}-2^{3}$ & BDS & $1,775-2,175$ & $\mathrm{~V}_{\mathrm{d}}=\mathrm{M}_{\mathrm{d}}-0.52$ & $2,044.4$ & 0.5 \\
\hline WW-A ${ }^{4}$ & BDS & $1,575-1,850$ & $\mathrm{~V}_{\mathrm{d}}=\mathrm{M}_{\mathrm{d}}-3.00$ & $1,608.8$ & 3.0 \\
\hline WW-C-1 & BDS & $\begin{array}{l}1,525-1,550 \\
1,550-1,575 \\
1,575-1,600\end{array}$ & $\begin{array}{l}\mathrm{V}_{\mathrm{d}}=\mathrm{M}_{\mathrm{d}} * 0.9848+19.21 \\
\mathrm{~V}_{\mathrm{d}}=\mathrm{M}_{\mathrm{d}} * 0.9772+30.99 \\
\mathrm{~V}_{\mathrm{d}}=\mathrm{M}_{\mathrm{d}} * 0.966+48.63\end{array}$ & $\begin{array}{r}1,544.0 \\
-- \\
1,599.4\end{array}$ & $\begin{array}{c}4.3 \\
-- \\
5.7\end{array}$ \\
\hline
\end{tabular}

\footnotetext{
${ }^{1}$ Sporadic borehole-deviation measurements were obtained from drilling records.

${ }^{2}$ Includes wells UE-10j (2232-2613 ft), UE-10j (2232-2297 ft), and UE-10j (2380 ft).

${ }^{3}$ Includes wells WW-2 (2045 ft), WW-2 (2535 ft), WW-2 (2896 ft), WW-2 (3422 ft), and WW-2 (3422 ft, uncased).

${ }^{4}$ Includes wells WW-A (1730 ft) and WW-A (1870 ft).
} 
equation of the form:

$$
\mathrm{V}_{\mathrm{d}}=\left(\mathrm{M}_{\mathrm{d}}-\mathrm{M}_{\text {top }}\right) *\left(\Delta \mathrm{V}_{\text {int }} / \Delta \mathrm{M}_{\text {int }}\right)+\mathrm{V}_{\text {top }}
$$

where

$\mathrm{V}_{\mathrm{d}}$ is corrected vertical water-level depth, in feet below land surface;

$M_{d} \quad$ is measured water-level depth, in feet below land surface;

$M_{\text {top }} \quad$ is measured depth to top of depth interval over which correction applies, in feet below land surface;

$\Delta \mathrm{V}_{\text {int }} \quad$ is difference in true vertical depths between top and bottom of depth interval, in feet below land surface;

$\Delta \mathrm{M}_{\mathrm{int}} \quad$ is difference in measured depths between top and bottom of depth interval, in feet below land surface; and

$\mathrm{V}_{\text {top }} \quad$ is true vertical depth to top of depth interval, in feet below land surface.

As an example, a borehole deviation survey for well UE-10j (U.S. Geological Survey data files, Henderson, Nev.) shows that a measured depth interval of 2,100-2,200 ft below land surface can be used to bound historic water-level measurements in this borehole (table 2). The corresponding true-vertical depths from the deviation survey at the top and the bottom of this interval are 2,097.99 ft and 2,197.26 ft, respectively. Substituting these values into equation 1 gives the linear water-level adjustment for the depth interval that bounds historic water levels (table 4):

$\mathrm{V}_{\mathrm{d}}=\left(\mathrm{M}_{\mathrm{d}}-2,100 \mathrm{ft}\right)^{*}(99.27 \mathrm{ft} / 100.00 \mathrm{ft})+2,097.99 \mathrm{ft}$.

In reduced form, equation (2) becomes:

$$
\mathrm{V}_{\mathrm{d}}=\mathrm{M}_{\mathrm{d}} * 0.9927+13.32 \mathrm{ft} \text {. }
$$

Water levels in 18 wells from 11 boreholes in Yucca Flat were corrected for borehole deviation (table 4). The mean water-level adjustment for borehole deviation in slant holes (boreholes intentionally drilled at an angle) ranged from 46 to $180 \mathrm{ft}$. In the remaining boreholes, water-level adjustments were less than $6 \mathrm{ft}$.

\section{Land-Surface Altitude}

Land-surface altitudes for most of the wells in Yucca Flat were determined from surveys by NTS contractors as part of well construction, either shortly before drilling or shortly after initial well completion. Prior to 1990, most of these altitudes were obtained using standard leveling surveys. More recent altitudes were determined by differential Global Positioning System (DGPS) surveys (Rick Remington, Bechtel Nevada, written commun., 2004). The accuracies of the surveyed altitudes are recorded as $\pm 0.1 \mathrm{ft}$, but true errors could be greater depending on the accuracy of the benchmark(s) on which a survey is based. Altitudes for a few of the wells in Yucca Flat were estimated from topographic maps.
In 2003, the USGS used high-precision DGPS methods to resurvey 41 of the active water-level monitoring wells in Yucca Flat. High-precision control points were established at four existing benchmarks on the west and east sides of Yucca Flat. Altitudes for the control points were obtained from two 24-hour occupations at each point using dual-frequency GPS receivers. The altitudes are tied into the national Continuously Operating Reference Stations (CORS) network, which is coordinated by the National Geodetic Survey of the National Oceanic and Atmospheric Administration. A Real Time Kinematic (RTK) system was set up using these control points to run DGPS surveys to each of the 41 wells. The measuringpoint (MP) altitude of each well was measured directly from the GPS survey. The land-surface altitude was calculated by subtracting the height of the MP above land surface from the MP altitude. The altitudes are assumed to be accurate to \pm 0.2 $\mathrm{ft}$ based on the repeatability of measurements over multiple setups.

The land-surface altitudes were resurveyed by the USGS to confirm or improve the accuracy of the altitudes measured during well construction. Additionally, at some wells in Yucca Flat, land-surface altitudes may be changing with time because of subsidence. Subsidence has been documented in the underground testing area of Yucca Flat using interferometric synthetic aperture radar (InSAR). Subsidence was reported to extend about $0.6 \mathrm{mi}$ in diameter around individual underground nuclear tests (Vincent and others, 2003). These subsidence zones around individual tests can overlap to form larger oval-shaped subsidence areas, which are concentrated primarily between the Yucca and Topgallant faults (fig. 3; Laczniak and others, 2003). Between 1992 and 1997, subsidence of as much as $0.5 \mathrm{ft}$ in Yucca Flat was documented with InSAR (Laczniak and others, 2003).

Where subsidence occurs, the measured depth to water can decrease with time solely because of a changing land-surface datum. Because land-surface datums were not adjusted with time to account for subsidence, artificial rising trends in water-level altitudes at wells affected by subsidence may be incorporated into the water-level record. Assuming the waterlevel altitude remains unchanged, the rate of apparent rise in water level will be directly proportional to the rate of subsidence in land surface. Distinguishing changes in water-level depth that are caused by subsidence is difficult without regular monitoring of land-surface altitude.

The original land-surface altitudes measured at the time of well construction and altitudes from the 2003 USGS surveys are listed in table 5. Altitudes established at the time of well construction, for the wells in table 5, were determined during a period of more than 40 years. The differences in landsurface altitude between the well-construction surveys and the USGS 2003 surveys range from +2.84 to $-5.64 \mathrm{ft}$ (table 5).

The differences in land-surface altitudes are attributed to errors in altitude measurements during surveying, the use of different land-surface datums between surveys, or an actual change in land-surface altitude. Because the exact point on the ground used as land-surface datum during the well-construc- 
Table 5. Survey estimates of land-surface and measuring-point altitudes for water-level monitoring wells in Yucca Flat

[Surveys were done at the time of well construction and in 2003. Altitudes in feet above sea level; MP height in feet above land surface. Abbreviations: LS, land surface; MP, measuring point for water-level measurement]

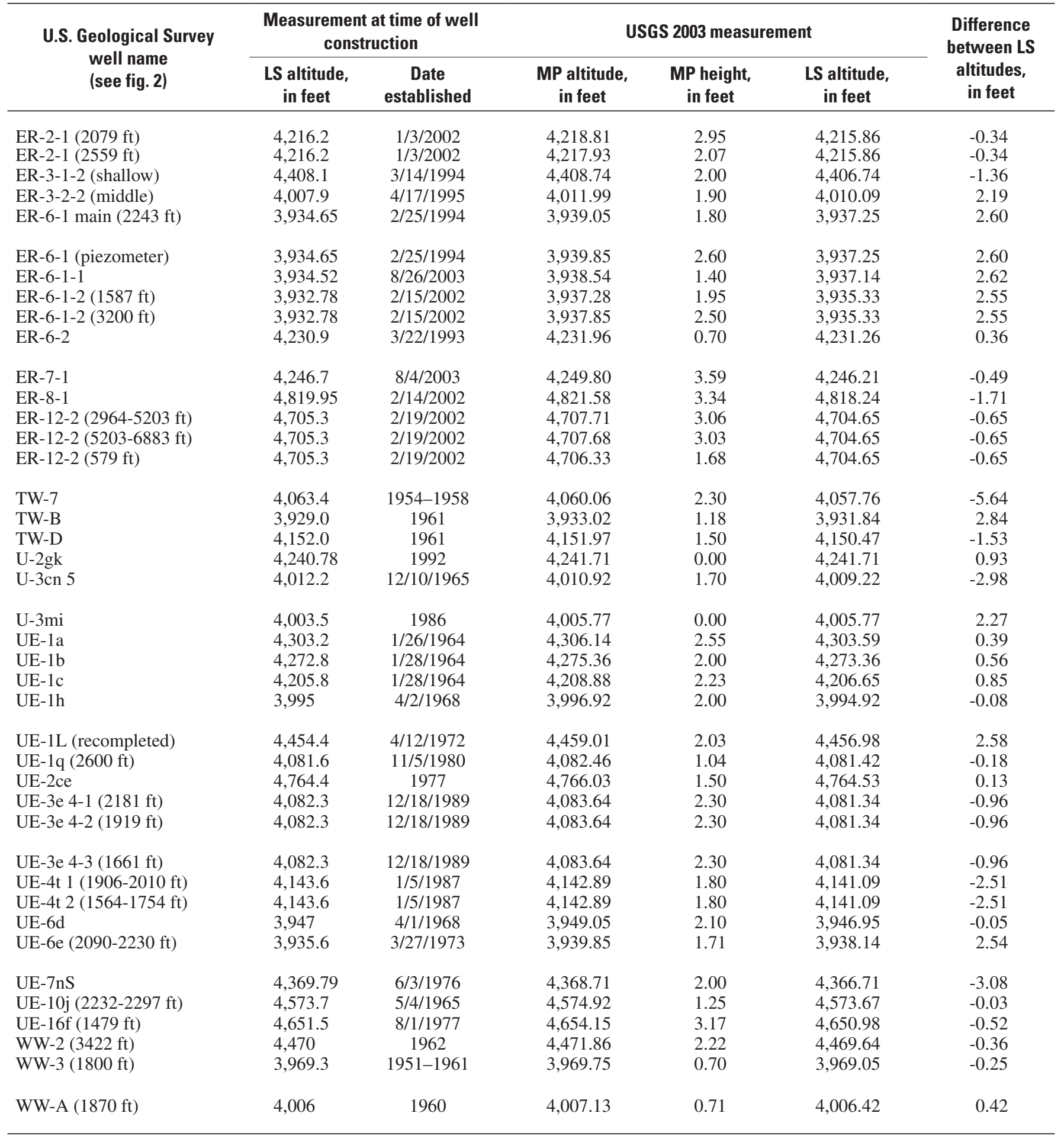


tion survey is not known, it could not be duplicated during the 2003 USGS survey. Therefore, even at wells where surveymeasurement errors may be negligible, land-surface altitudes cannot be directly compared because of potentially inconsistent land-surface datums. Water levels were not corrected for changes in land-surface datum because of these potential errors.

Some of the wells with large negative differences in land-surface altitude may be affected by subsidence at the well site. Of the 11 wells in 8 boreholes where relatively large (from -0.96 to $-5.64 \mathrm{ft}$ ) potential downward movement of land surface is indicated, most of these wells are in areas where subsidence is expected to have occurred. For example, the land-surface altitude at well TW-7 shows an apparent downward shift of more than $5 \mathrm{ft}$. Some of this change is directly related to underground nuclear tests (Garber, 1963, p. 3; Hale and others, 1963, p. 14-17).

\section{Water Temperature}

Water levels in a well can be affected by the temperature of the water in the well. An anomalously high water temperature will result in water that has a relatively low density. For a given pressure head, warm (low density) water causes the water level in a well to rise higher than it would with "normaltemperature" water; likewise, cool (high density) water will cause the water level to be lower.

In some cases, water levels may need to be corrected for spatial and temporal variations in water temperature. Correcting for spatial differences in temperature among wells can be important when comparing heads for hydraulic-gradient calculations. Where ground-water gradients are low relative to the magnitude of temperature corrections, uncorrected hydraulic heads in wells may result in determinations of erroneous directions of ground-water flow. Temporal variations of water temperature in a well should be considered when determining the cause of a water-level trend in the well. A decreasing or increasing water temperature with time will cause an apparent decreasing or increasing water-level trend. Water temperature can change temporally because of the effects of a nearby nuclear test or from circulation of thermal water in a borehole during well construction, development, and aquifer testing.

Adjusting water levels for temperature effects, or more precisely, density effects, requires information that is not available for most wells in Yucca Flat. Although temperature is likely to be the most important factor affecting borehole fluid density in these wells, other factors such as dissolved and suspended solids, nonaqueous phase liquids (most likely associated with drilling of a well or leakage of oil from pumps), the compressibility of water caused by pressure from the overlying water column, and gravitational effects can influence the density. To adjust water levels for temperature effects, the zone or zones of inflow to the well must be known. Additionally, a temperature distribution from the point of lowest inflow in the well to the top of the water column is needed. Determining the zone(s) of inflow is critical in wells with several thousand feet of open interval because density corrections are applied only to the length of the water column above the lowest zone of inflow.

The effect that water temperature in a well has on the estimate of hydraulic head can be determined if the mean water temperature and length of the water column above the point of inflow in a well are known. The following equation, described by Winograd (1970), can be used to calculate a water-level correction resulting from a temperature adjustment:

$$
n^{\prime}=\frac{s}{s^{\prime}} * n
$$

where

$n^{\prime}$ is the temperature-corrected length of water column above the point of inflow for a given temperature adjustment;

$n$ is the measured water-column length above the point of inflow (assumed to be the middle of the open interval, in this report);

$s$ is the specific weight (or density) of water in the column at the mean measured water-column temperature and hydrostatic pressure; and

$s^{\prime}$ is the specific weight (or density) of water at the adjusted temperature and identical hydrostatic pressure.

The Thiesen-Scheel-Diesselhorst equation (McCutcheon and others, 1993) can be used to calculate the density of pure water for a specified temperature:

$$
\rho=1,000\left[1-\frac{(T+288.9414)}{508,929.2 *(T+68.12963)}(T-3.9863)^{2}\right],
$$

where

$\rho$ is density of water, in kilograms per cubic meter; and

$T$ is temperature of water, in degrees Celsius.

A cursory examination of 44 wells in Yucca Flat with available water-level and temperature data indicates that waterlevel corrections in most wells would be less than $2 \mathrm{ft}$ if all water temperatures were adjusted to a temperature of $30^{\circ} \mathrm{C}$ (table 6). Wells with the largest corrections are influenced either by long water-column lengths (greater than about 1,000 $\mathrm{ft}$ ) or, to a lesser degree, by mean water-column temperatures that differ by more than $10^{\circ} \mathrm{C}$ from $30^{\circ} \mathrm{C}$. Wells with potential corrections of more than $2 \mathrm{ft}$ are ER-12-2 (5203-6883 ft), ER12-2 (2964-5203 ft), ER-6-1-2 (3200 ft), U-3cn 5, and UE-4t 1 (1906-2010 ft).

Table 6 only should be used to illustrate the approximate magnitude of the effects of water temperature on hydraulichead estimates. Each of the assumptions used in determining water-level corrections - a constant geothermal gradient of $0.7^{\circ} \mathrm{C}$ per $100 \mathrm{ft}$, a water-column length extending from the 
Table 6. Approximate effects of temperature on hydraulic-head estimates for selected wells in the Yucca Flat area

Length of saturated open interval: Length is measured from bottom of open interval in well to top of open interval or top of water surface, whichever length is less.

Water-level depth: Depth to water at time of water-temperature measurement.

Water temperature at surface: Measured in 2003, 5 feet below surface of water in well.

Estimated average water temperature: Average water-column temperature, assuming geothermal gradient of 0.7 degrees Celsius $\left({ }^{\circ} \mathrm{C}\right)$ per 100 feet.

Measured water-column length: Length of water column in well from mid-point of saturated open interval to top of water.

Temperature-adjusted water-column length: Length of water column in well if water temperature is adjusted to 30 degrees Celsius.

Water-level adjustment: Approximate adjustment to measured water level that is needed to account for effects of spatially variable water temperatures on hydraulic heads in wells. Water levels were adjusted to a common water temperature of 30 degrees Celsius.

\begin{tabular}{|c|c|c|c|c|c|c|c|}
\hline $\begin{array}{l}\text { U.S. Geological Survey } \\
\text { well name } \\
\text { (see fig. 2) }\end{array}$ & $\begin{array}{l}\text { Length of } \\
\text { saturated } \\
\text { open } \\
\text { interval, } \\
\text { in feet }\end{array}$ & $\begin{array}{l}\text { Water-level } \\
\text { depth, in feet } \\
\text { below land } \\
\text { surface }\end{array}$ & $\begin{array}{l}\text { Water } \\
\text { temperature } \\
\text { at surface, } \\
\text { in }{ }^{\circ} \mathrm{C}\end{array}$ & $\begin{array}{c}\text { Estimated } \\
\text { average } \\
\text { water } \\
\text { temperature, } \\
\text { in }{ }^{\circ} \mathrm{C} \\
\end{array}$ & $\begin{array}{l}\text { Measured } \\
\text { water- } \\
\text { column } \\
\text { length, } \\
\text { in feet } \\
\end{array}$ & $\begin{array}{l}\text { Temperature- } \\
\text { adjusted } \\
\text { water-column } \\
\text { length, in feet }\end{array}$ & $\begin{array}{l}\text { Water-level } \\
\text { adjustment, } \\
\text { in feet }\end{array}$ \\
\hline ER-12-2 (5203-6883 ft) & 1,680 & 193 & 19.6 & 40.1 & $5,850.17$ & $5,829.82$ & -20.35 \\
\hline ER-12-2 (2964-5203 ft) & 2,239 & 193 & 19.5 & 34.3 & $3,890.47$ & $3,885.12$ & -5.35 \\
\hline ER-6-1-2 (3200 ft) & 1,425 & 1,545 & 38.0 & 41.6 & 942.50 & 938.67 & -3.83 \\
\hline ER-6-2 & 1,646 & 1,784 & 33.5 & 36.7 & 823.00 & 821.18 & -1.82 \\
\hline ER-3-1-2 (shallow) & 102 & 2,016 & 48.6 & 49.6 & 243.15 & 241.34 & -1.81 \\
\hline ER-6-1 main $(2243 \mathrm{ft})$ & 424 & 1,547 & 38.2 & 40.1 & 484.08 & 482.40 & -1.68 \\
\hline ER-6-1-1 & 217 & 1,547 & 37.8 & 39.3 & 396.85 & 395.59 & -1.26 \\
\hline UE-7nS & 235 & 1,970 & 41.4 & 41.9 & 117.69 & 117.20 & -0.49 \\
\hline UE-10j (2232-2297 ft) & 65 & 2,160 & 32.1 & 32.5 & 104.65 & 104.57 & -0.08 \\
\hline ER-6-1 (piezometer) & 68 & 1,474 & 36.6 & 36.7 & 34.04 & 33.96 & -0.08 \\
\hline $\mathrm{U}-2 \mathrm{gk}$ & 31 & 1,778 & 27.8 & 27.9 & 15.62 & 15.62 & 0.01 \\
\hline U-15k Test Hole & 62 & 762 & 21.3 & 21.4 & 30.77 & 30.84 & 0.07 \\
\hline TW-D & 227 & 1,723 & 26.4 & 26.9 & 113.30 & 113.40 & 0.10 \\
\hline TW-B & 171 & 1,504 & 24.8 & 25.1 & 85.49 & 85.61 & 0.12 \\
\hline UE-3e 4-3 (1661 ft) & 120 & 1,548 & 20.4 & 20.6 & 59.77 & 59.92 & 0.15 \\
\hline $\mathrm{U}-7 \mathrm{~cd}$ & 199 & 1,426 & 23.2 & 23.6 & 99.48 & 99.65 & 0.17 \\
\hline WW-A (1870 ft) & 269 & 1,601 & 24.7 & 25.2 & 134.61 & 134.79 & 0.18 \\
\hline UE-1c & 583 & 1,297 & 26.1 & 27.2 & 291.32 & 291.55 & 0.23 \\
\hline ER-2-1 (2079 ft) & 454 & 1,723 & 24.9 & 25.8 & 227.16 & 227.43 & 0.27 \\
\hline UE-14b & 1,629 & 1,667 & 23.6 & 28.2 & $1,198.96$ & $1,199.60$ & 0.64 \\
\hline UE-1q (2600 ft) & 141 & 1,656 & 23.8 & 27.2 & 873.96 & 874.68 & 0.72 \\
\hline UE-6e (2090-2230 ft) & 140 & 1,510 & 22.2 & 24.7 & 650.48 & 651.44 & 0.96 \\
\hline UE-3e 4-2 (1919ft) & 94 & 1,418 & 20.1 & 21.8 & 461.29 & 462.29 & 1.00 \\
\hline UE-1h & 1,224 & 1,555 & 22.2 & 26.7 & $1,191.17$ & $1,192.31$ & 1.14 \\
\hline UE- 1L (recompleted) & 1,568 & 519 & 21.4 & 25.2 & 981.48 & 982.81 & 1.33 \\
\hline UE-6d & 1,771 & 1,514 & 20.4 & 26.0 & $1,496.31$ & $1,498.00$ & 1.69 \\
\hline UE-3e 4-1 (2181ft) & 98 & 1,189 & 19.3 & 22.9 & 953.56 & 955.39 & 1.83 \\
\hline UE-16f (1479 ft) & 186 & 367 & 19.3 & 23.2 & $1,019.29$ & $1,021.18$ & 1.89 \\
\hline ER-2-1 $(2559 \mathrm{ft})$ & 287 & 609 & 19.2 & 26.2 & $1,847.50$ & $1,849.49$ & 1.99 \\
\hline UE-4t $1(1906-2010 \mathrm{ft})$ & 104 & 485 & 19.0 & 24.6 & $1,473.26$ & $1,475.46$ & 2.20 \\
\hline
\end{tabular}


middle of the open interval to the water surface, and adjustment of all water temperatures to $30^{\circ} \mathrm{C}$-have an effect on the estimated water-level corrections. Information on zones of inflow to the well in combination with an adequate vertical temperature profile of the water column are needed to determine accurate hydraulic heads in wells. An adequate temperature profile in a well must extend from the top of the water column to the lowest zone of inflow and must be made after the water in the well equilibrates with formation-water temperatures.

\section{Causes of Water-Level Fluctuations}

Water levels in wells at Yucca Flat fluctuate because of natural and anthropogenic causes. Natural causes include barometric pressure, Earth tides, and recharge from precipitation. Anthropogenic causes include ground-water withdrawals, equilibration following drilling activities, land subsidence, and underground nuclear testing. Some of these factors, such as recharge, can have relatively slow response times that may cause long-term changes in regional water levels. Other factors, such as barometric pressure, may be relatively instantaneous and have only a short-term effect on water levels.

\section{Barometric Pressure and Earth Tides}

Changes in barometric pressure and Earth tides cause water-level fluctuations in wells throughout Yucca Flat. These fluctuations typically are largest in wells open to confined aquifers. The combined water-level response from barometric pressure and Earth tides is less than $1 \mathrm{ft}$ and may result in daily to annual fluctuations. Barometric pressure and Earth tides are not likely to have an effect on long-term water-level trends.

Barometric-induced fluctuations commonly are caused by instantaneous responses to atmospheric loads transferred directly to the aquifer and to the water column in an open well (Brassington, 1998, p. 102). However, water-level responses also can lag because of drainage effects and the time necessary for air moving through the unsaturated zone to transfer the load to the water table (Rojstaczer, 1988; Weeks, 1979). Instantaneous changes in water level that result from atmospheric loading are the balance of two opposing effects. The load associated with an increase in barometric pressure will (1) push down on the water column in an open well, resulting in a relatively large drop in water level, and (2) pressurize the aquifer, resulting in a relatively small rise in water level. Typically, in a well open to the atmosphere, an increase in barometric pressure causes an instantaneous drop in water level, and a decrease causes an instantaneous rise. Water levels will respond to daily and seasonal fluctuations in barometric pressure related to heating of the atmosphere as well as changes in barometric pressure caused by changing weather fronts.
The effects of barometric pressure and Earth tides on water levels for selected Yucca Flat wells were estimated by a linear-optimization process using the Solver tool in Microsoft@ Excel. Theoretical Earth-tide responses were generated using computer programs from Harrison (1971). Time series of measured barometric pressure and theoretical Earth tides at a well were fitted to measured water levels at the well by adjusting the amplitude and phase of each time series. Simulated water levels were generated that were a best fit between measured water levels and the barometric pressure and Earthtide responses. The best fit was obtained by minimizing the sum-of-square differences between the simulated and measured water levels.

The response of water levels to barometric pressure is shown in figure 8 . In this figure, measured water levels show an inverse response to barometric pressure (fig. 8A). However, only some of the short-term, water-level fluctuations in this well are attributed to changes in barometric pressure. Most of the residual water-level fluctuations that exist after removing the barometric-pressure signal are attributed to Earth tides (figs. $8 B$ and $8 C$ ). Most of the small fluctuations that remain after removal of Earth-tide effects likely result from imperfect removal of these effects from the record.

\section{Precipitation}

Precipitation in southern Nevada ranges from less than 4 in/yr in low-lying valleys to more than $20 \mathrm{in} / \mathrm{yr}$ in the Spring Mountains. In Yucca Flat, precipitation averages 6-7 in/yr on the valley floor and 8-14 in/yr on the nearby upland areas to the west and northwest (Air Resources Laboratory, Special Operations and Research Division, 2004). About two-thirds to three-quarters of annual precipitation falls during winter storms, which are usually of low intensity and areally extensive.

Precipitation data from 1964 to 2003 were compiled and trends in the data were analyzed for selected precipitation stations within the region surrounding Yucca Flat. Location and altitude information for all precipitation sites used for this report are listed in table 7. The sites were selected to represent three general areas of recharge near Yucca Flat: the Spring Mountains to the south, Rainier Mesa to the northwest, and Pahranagat Valley to the northeast (fig. 1).

A Spring Mountains precipitation index was created from three high-altitude precipitation stations within the Spring Mountains: Kyle Canyon (7,500 ft), Lee Canyon (8,400 ft), and Adams Ranch (9,050 ft). Precipitation is measured at these stations once each year around June by the Nevada Division of Water Resources. Annual data for the three stations were averaged to create the precipitation index. An index using the mean from multiple stations minimizes errors in data collection as well as data estimation.

Monthly data from three precipitation stations in recharge areas to the west and northwest of Yucca Flat were averaged to create the Rainier Mesa precipitation index (table 7). The data were obtained from the Air Resources Laboratory (ARL), 


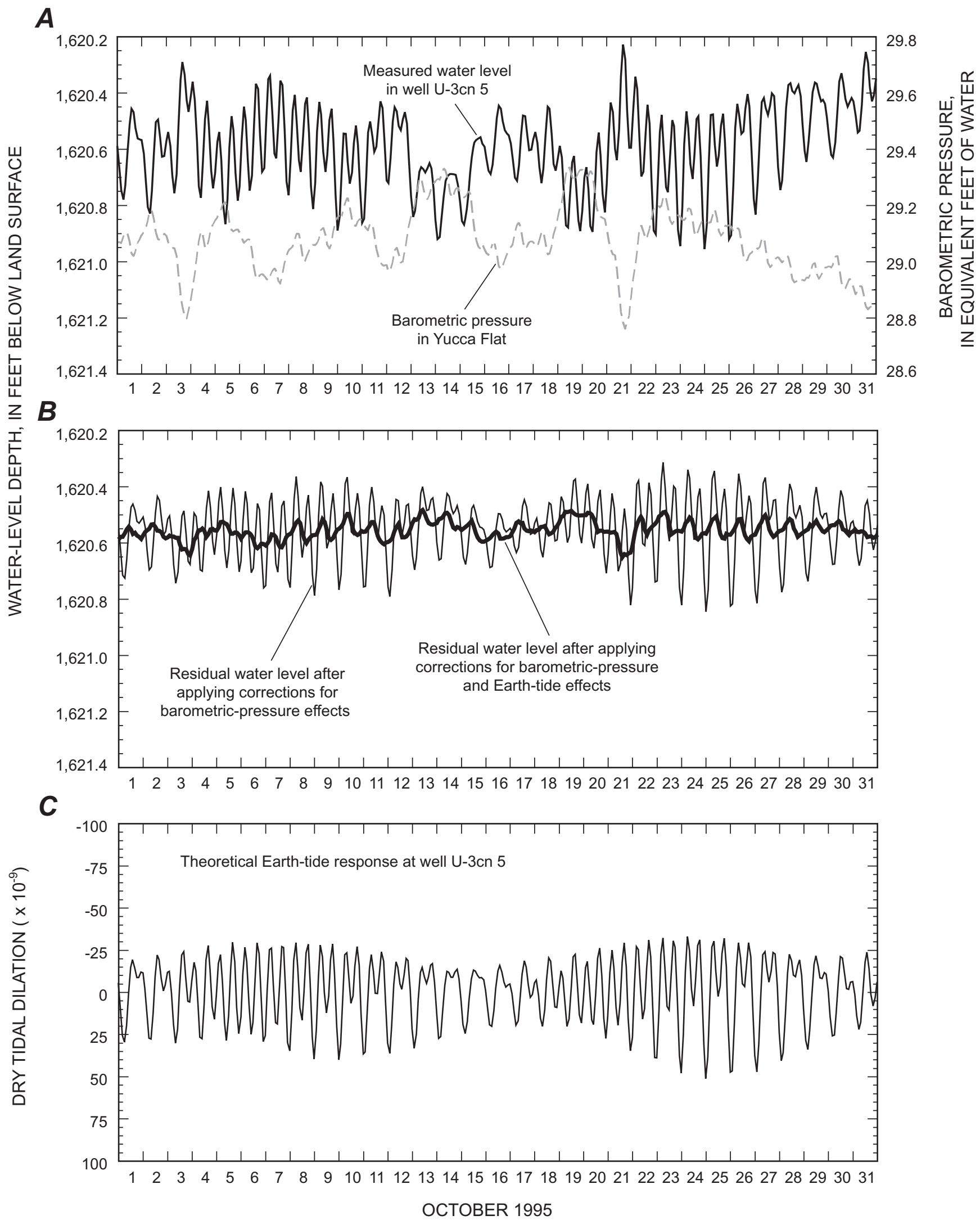

Figure 8. Graphs showing short-term response of water levels in well U-3cn 5 to barometric pressure and Earth tides, October 1995. 
Table 7. Information for precipitation sites used to create precipitation indices for Yucca Flat

Precipitation index: Name of precipitation index in which precipitation station is included.

Mean annual precipitation: Mean based on period 1964-2003.

Reporting agency: NDWR, Nevada Division of Water Resources; ARL/DOE, Air Resources Laboratory/U.S. Department of Energy; NOAA/NWS, National Oceanic and Atmospheric Administration/National Weather Service.

[Abbreviation: NWR, National Wildlife Refuge]

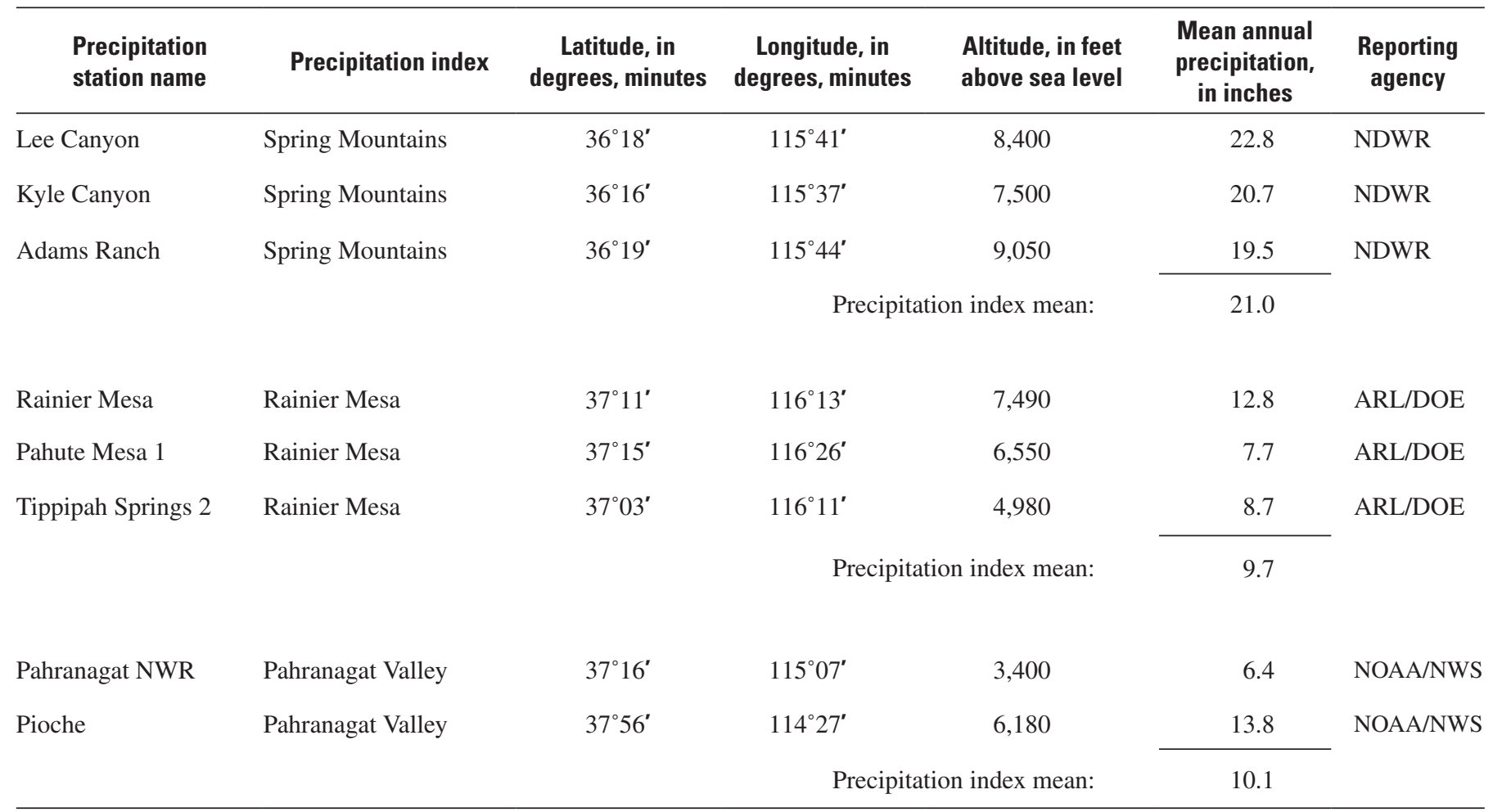

Special Operations and Research Division (SORD). SORD conducts basic and applied research on problems of mutual interest to DOE and National Oceanic and Atmospheric Administration (NOAA) that relate to the NTS.

Monthly data from two precipitation stations, selected to represent recharge patterns occurring northeast of Yucca Flat, were averaged to create a Pahranagat Valley index (table 7). The stations are part of the NOAA-National Weather Service cooperative observer network. The stations are about 50 and 110 mi northeast of the study area and were selected based on a period of record of at least 30 years, active to the year 2003.

A plot of cumulative departure from mean annual precipitation was constructed for each of the three precipitation indices. The mean for each index was determined from the 40-year period, 1964-2003. The cumulative departure plot is useful for identifying precipitation trends over a number of years that are either drier or wetter than average (fig. 9). If the curve slopes upward, regardless of its position in relation to the zero line, the trend indicates a wetter-than-average period; whereas, a downward-trending slope represents a drier-thanaverage period relative to the period of record. A steep slope represents a greater departure from the mean than a shallow slope, and, therefore, an extreme wet or dry period relative to the period of record.

A LOcally WEighted Scatterplot Smooth (LOWESS) line was fitted to the cumulative-departure data to identify significant and relatively long-term (greater than 5 years) trends in precipitation that might affect regional ground-water levels. The locally weighted regression smoothing function in the S-Plus 6.1 software package (Insightful Corporation, 2001) was used in this study to generate LOWESS trends.

LOWESS is a nonparametric method of fitting a curved line to data (Helsel and Hirsch, 1992, p. 288-291). At each data point, a predicted value is computed using a weighted linear regression. Predicted values are then connected to create a smoothed line. Weights were determined through trial and error to create a smooth that reflected relatively longterm patterns. LOWESS trend lines are preferable to linear regression for determining cyclic or nonlinear trends in data. A LOWESS trend line is helpful for identifying similarities and differences in trends between sites. The line can be useful for discerning a pattern or trend in data with scatter. 

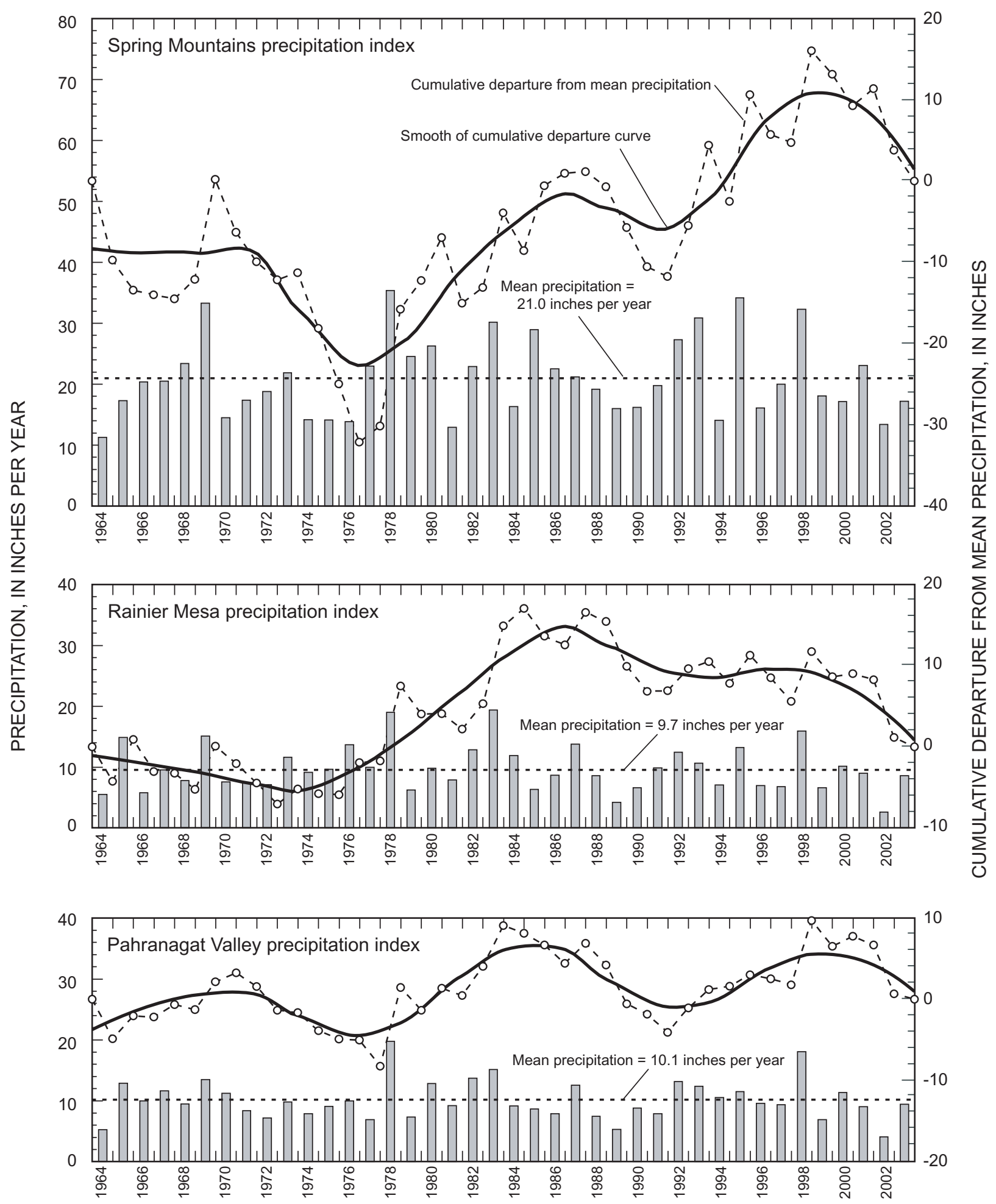

Figure 9. Graphs showing annual precipitation and cumulative departure from mean precipitation at index sites in the Spring Mountains, Rainier Mesa, and Pahranagat Valley, 1964-2003. Wet periods are shown by increasing slope in cumulative departure curve, dry periods by decreasing slope. Scales on all plots are the same. 
The plots of cumulative departure from mean precipitation for the Spring Mountains, Rainier Mesa, and Pahranagat Valley (fig. 9) show annual variations and regional, long-term trends in precipitation. The trends are somewhat similar for all three indices. However, for the period 1987-2003, the Spring Mountains index had an overall rising trend (wetter-than-average period), despite dry periods for 1988-1991 and 19992003. In contrast, the Rainier Mesa index had a declining trend for the period 1987-2003.

Long-term changes in precipitation are likely to affect regional ground-water levels. In shallow alluvial aquifers in east-central Nevada, water levels responded to long-term (10 years) drier- or wetter-than-normal periods of precipitation (Dettinger and Schaefer, 1995). In deeper aquifers (greater than 1,000 ft below land surface), water levels also may show evidence of responding to drier- or wetter-than-normal periods of precipitation. On the east side of the NTS, water levels in the regional Paleozoic carbonate-rock aquifer may correlate, after a lag time of about 3-4 years, to departures from normal precipitation (Bright and others, 2001; Fenelon and Moreo, 2002). At Yucca Mountain, Lehman and Brown (1996) suggested precipitation as a possible cause of apparent cyclic water-level fluctuations in wells penetrating volcanic rocks at depths from 1,200 to 4,000 ft below land surface.

\section{Ground-Water Withdrawals}

About 17,000 acre-ft of water were withdrawn from nine wells in Yucca Flat between 1952 and 2003; five of these wells have total withdrawals of more than 2,000 acre-ft each (fig. 10). Ninety-nine percent of the withdrawals from Yucca Flat occurred after 1960, which coincides with widespread nuclear testing in Yucca Flat. Total annual withdrawals in Yucca Flat peaked in 1969 at about 860 acre-ft/yr and then slowly declined to about 140 acre-ft/yr in 2003 (fig. 11). Eighty percent of the water withdrawn in Yucca Flat was from carbonate-rock aquifers; the remaining water was derived from the valley-fill aquifer (fig. 11).

From 1961 to 2003, an average of 390 acre-ft/yr of water was withdrawn from wells in Yucca Flat. An average withdrawal of this magnitude implies that slightly more water is withdrawn from Yucca Flat than naturally flows into the basin, as estimated by Winograd and Thordarson (1975, p. 94). Water Well C and Water Well C-1, which produce from the lower carbonate-rock aquifer on the downgradient end of Yucca Flat, accounted for 44 percent of all water withdrawn from Yucca Flat through 2003.

\section{Underground Nuclear Tests and Earthquakes}

Underground nuclear tests have a large effect on water levels in Yucca Flat, whereas earthquakes probably do not. No change in periodic or continuous water levels in Yucca Flat could be attributed to an earthquake, despite documented effects in nearby areas (Fenelon and Moreo, 2002; O'Brien, 1992). Earthquakes likely affect water levels in Yucca Flat, but the effects probably are short-lived and are not apparent in quarterly water-level measurements. Although continuous water-level data is expected to show a response to earthquakes, almost none of the continuous data available in Yucca Flat (fig. 4) coincided with major earthquakes that occurred in 1992, 1994, and 1999. These earthquakes - the Landers, Northridge, and Hector Mine-were centered in California, more than $100 \mathrm{mi}$ from Yucca Flat.

Through 1992, 828 underground nuclear tests were conducted at the NTS, of which 659 were beneath Yucca Flat (U.S. Department of Energy, 2000). The last nuclear device was tested in September 1992, prior to the United States declaring a moratorium on nuclear testing. Some of the underground tests consisted of multiple simultaneous nuclear detonations in the same or nearby boreholes. In Yucca Flat, 747 nuclear devices were detonated during the 659 tests; 3 additional tests were done to the north of Yucca Flat (fig. 12; app. 2).

Nuclear tests affect water levels in Yucca Flat by four processes: seismic response, pore-water pressurization, porewater depressurization, and cavity infilling. The magnitude and duration of changes in water levels are affected by the size of, and distance from, a test. Close to a detonation, changes in water levels sometimes persist for years before equilibrium is reestablished. A brief description of the response of water levels to underground nuclear tests, summarized from Laczniak and others (1996, p. 42-44), is given below. Other published reports describing the effects of underground testing on water levels in Yucca Flat include Hale and others, 1963; Hawkins and others, 1987; Hoover and Trudeau, 1987; Hawkins and others, 1990; and Hale and others, 1995.

Following an underground nuclear detonation, a large amount of energy is released. A small part of this energy goes out in a seismic wave. When this wave propagates through the earth, ground-water levels at relatively large distances may be affected briefly by the ground motion (for example, see Dudley and Larson, 1976, p. 11). However, long-term effects on water levels from seismic responses are considered negligible.

At the site of the detonation, a test cavity is formed as the rock matrix is vaporized or compressed outward following the shock blast. Water levels are lowered instantaneously in the area of the cavity as water is expelled or vaporized by the blast. Shortly after the blast, the cavity may fill with rubble from above, but is devoid of water.

Within a few feet to several thousand feet of the edge of the cavity, water levels may rise rapidly in response to the shock wave from a nuclear detonation. The shock wave changes the matrix of nearby geologic deposits. Materials such as alluvium can compact, whereas low-permeability, air-fall and bedded tuffs can compress and deform (Hale and others, 1963). Each test pressurizes the alluvium or tuffs. Multiple detonations cumulatively can elevate water levels (Hoover and Trudeau, 1987). 

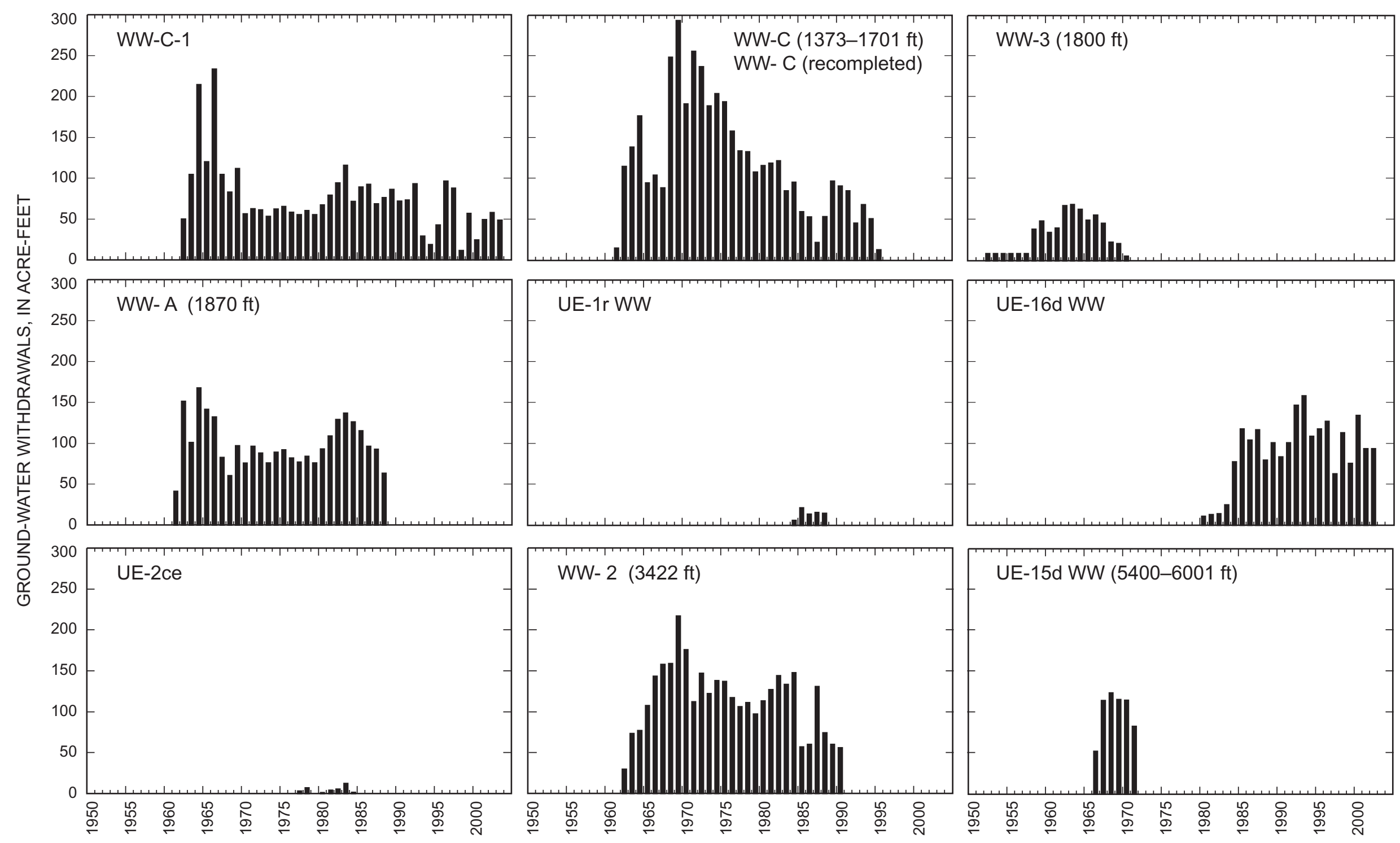
Figure 10. Graphs showing ground-water withdrawals by well in Yucca Flat, 1950-2003. Withd
NTS annual workforce populations (Moreo and others, 2003). For well location see figure 2 .

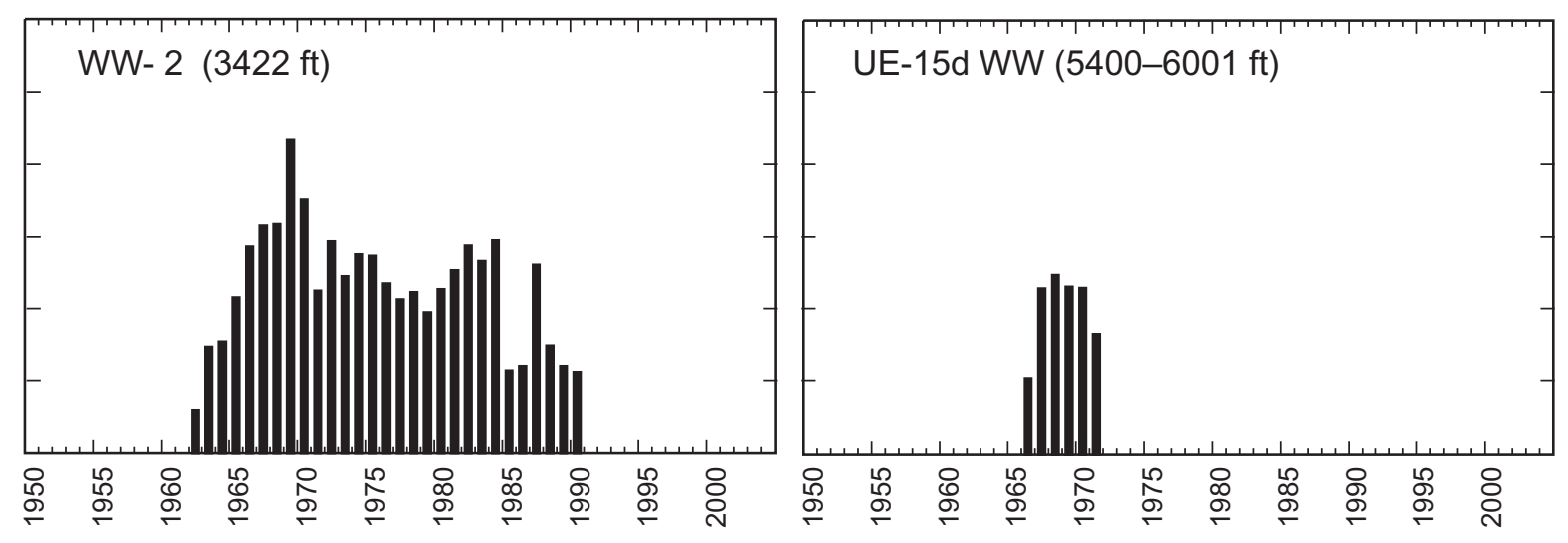

Figure 10. Graphs showing ground-water withdrawals by well in Yucca Flat, 1950-2003. Withdrawals from 1972-82 (with the exception of well UE-2ce) are estimates based on 


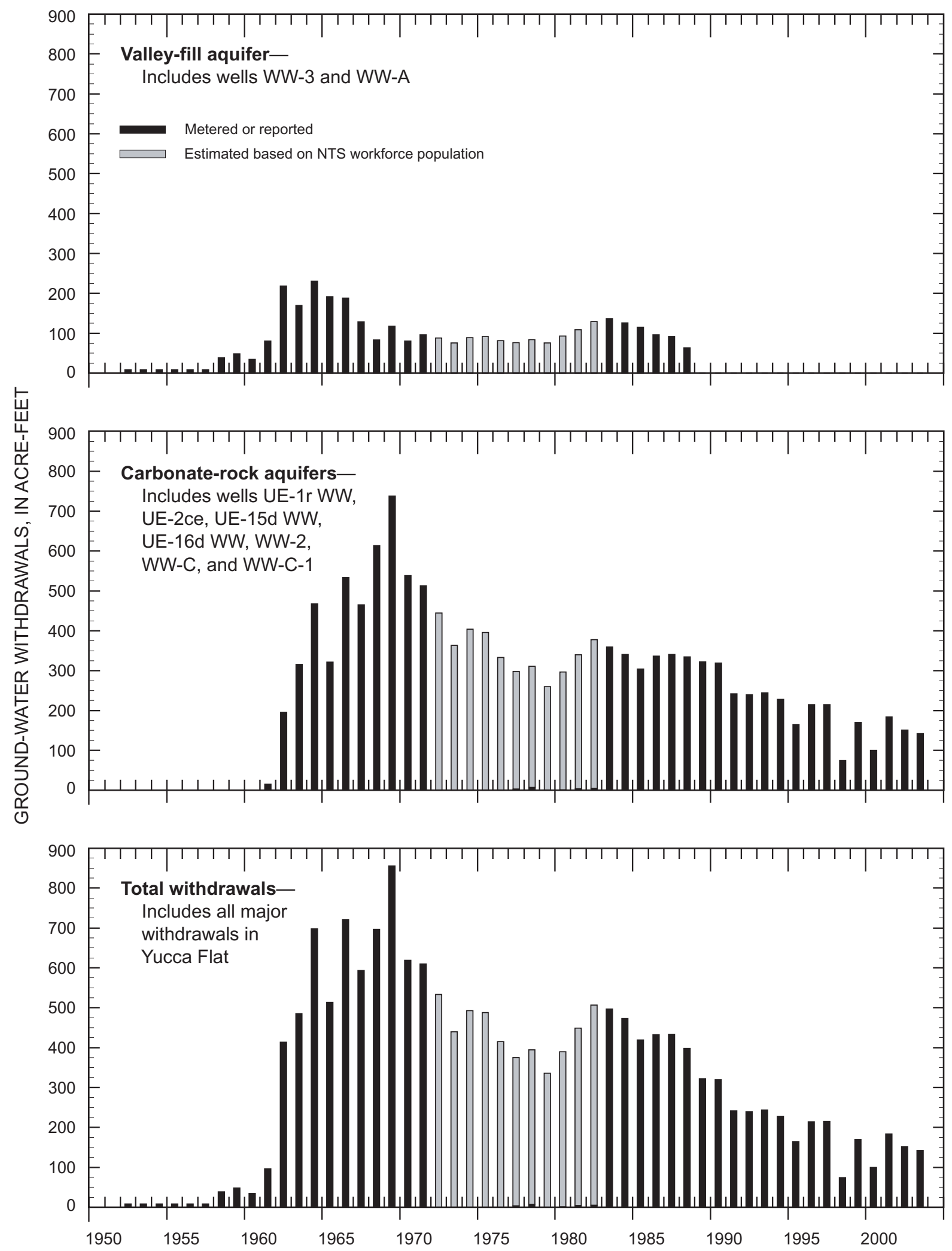

Figure 11. Graphs showing total annual withdrawals and withdrawals by aquifer type in Yucca Flat, 1950-2003. Withdrawals from carbonate-rock aquifers include the lower and upper carbonate-rock aquifers. For well location see figure 2. 


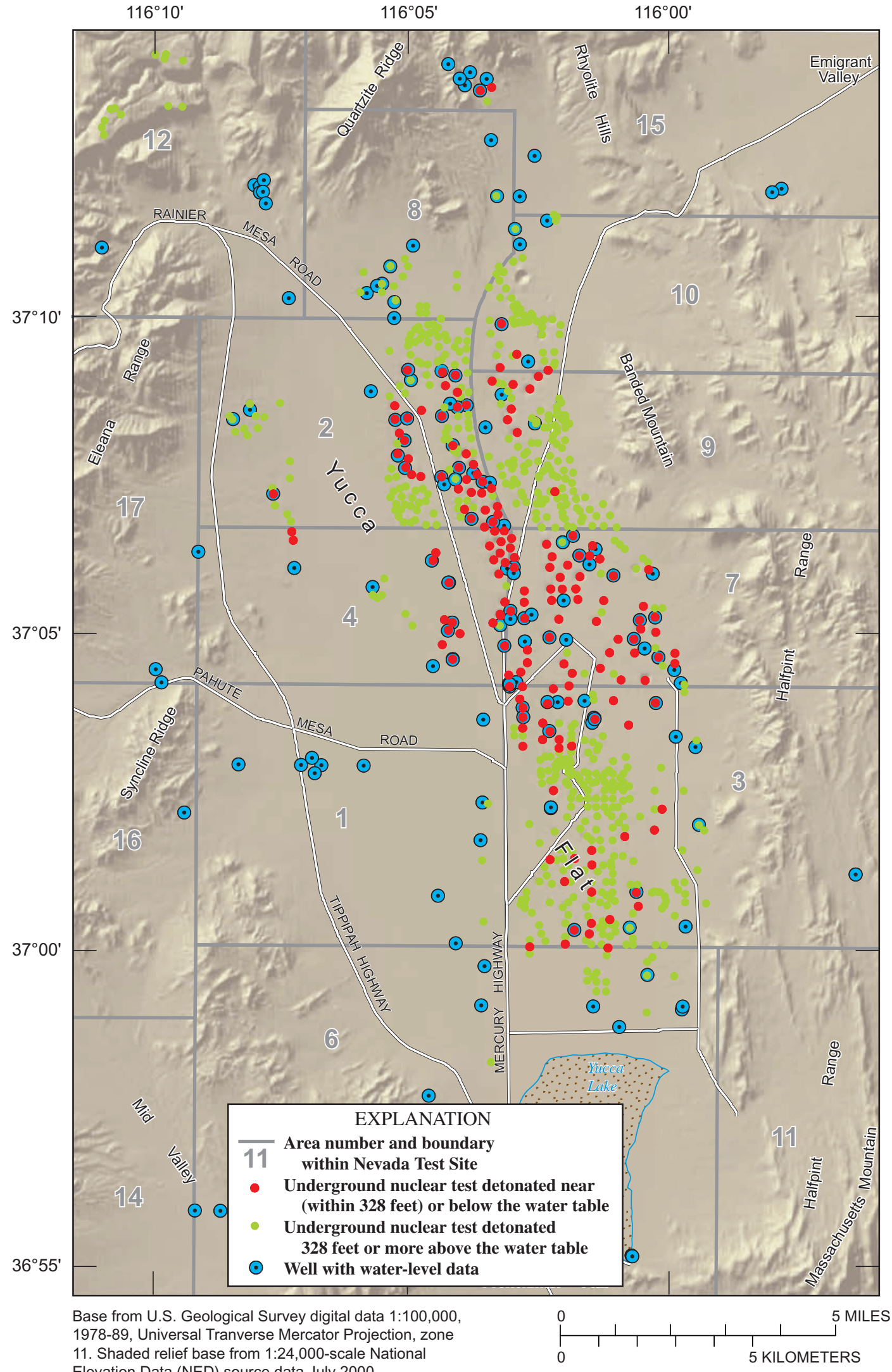

Elevation Data (NED) source data July 2000

Figure 12. Map showing distribution of underground nuclear tests in the Yucca Flat area, Nevada Test Site. 
In the months to years after a test, water levels decline as water flows from areas of high hydraulic head to areas of low head. In the confined tuffs, this results in upward movement of water to the water table, downward movement of water to the lower carbonate-rock aquifer (Hale and others, 1963, p. 20), and lateral movement of water into the test cavity or away from the pressurized zone. Water levels in the cavity will rise as a result of infilling of the test cavity.

The effects on water levels in close proximity to a nuclear test can be large and long-lasting. For this study, a nuclear test is considered unlikely to affect water levels if the test is greater than a lateral distance of $1 \mathrm{mi}$ and a vertical distance of $328 \mathrm{ft}$ from the water level. The largest reported yield in Yucca Flat for a nuclear test above the water table is less than or equal to 200 kilotons. A test of this magnitude is expected to create a test cavity with a radius of almost $328 \mathrm{ft}$ (U.S. Congress, Office of Technology Assessment, 1989, p. 37). Therefore, tests that were conducted more than $328 \mathrm{ft}$ above the water table were assumed, in general, to have minimal effect on water levels in Yucca Flat. The lateral and vertical distribution of underground nuclear tests in Yucca Flat is shown in figure 12.

\section{Analysis of Water Levels}

Water levels from 34 wells were analyzed for trends (table 8). Some of the trends were compared to potential factors causing the trends to better understand influences on the ground-water system. The wells selected for statistical trend analysis have at least 6 years of periodic water-level record. For most data sets, the 10-year period, 1994-2003, was used for trend analysis. This period was selected because the data sets had consistent semiannual or quarterly data; whereas, prior to 1994, water levels in many wells were measured sporadically or not at all. Water levels with general-condition attributes of "nonstatic level" or "suspect" (table 3) were excluded from the analysis. Nonstatic levels accounted for about 29 percent of the measured water levels in Yucca Flat. Most of these nonstatic levels were measured when water levels in a well were equilibrating following well construction or development.

Water-level data were statistically analyzed using the Mann-Kendall trend test (Helsel and Hirsch, 1992, p. 326-328). The Mann-Kendall method is a nonparametric test that determines whether a statistically significant upward or downward change in water level has occurred over the period of record analyzed. The method, which tests for a monotonic change, does not imply anything about the magnitude of the change or whether the change is linear. Because the MannKendall trend test is robust with respect to outliers, each data point is given equal treatment. Where data are irregularly spaced in time, specific time periods may be overrepresented or underrepresented on the overall trend. A 99-percent confidence level was used in the test for the statistical significance of an upward or downward change in water level.

Water-level data were analyzed further with LOWESS trend lines. Trend lines help display underlying patterns in data; especially where data scatter is high relative to the trend. LOWESS trend lines also were used because fitting a straight line through the data generally is not appropriate. Most causes of water-level fluctuations do not result in a linear or monotonic trend in one direction for long periods. For example, water levels can rise and fall with time because of the cyclic nature of recharge, changing rates of pumping in water-supply wells, and episodic nuclear testing.

Correlations of water levels with factors influencing trends were analyzed graphically. Graphical analysis was used to provide a visual indication of the overall strengths and weaknesses of a relation between two variables. In some cases, such as the effect of pumping on water levels, a mathematical correlation may not be evident. For example, following a sustained decrease in pumping, water levels may rise or they may continue to decline at a lesser rate. In this type of situation, the relation between pumping and water levels is difficult to analyze statistically but may be apparent in graphical form.

\section{Naturally Occurring Trends}

Water-level measurements that represent long-term, regional, steady-state conditions accounted for 37 percent of the water levels measured in Yucca Flat. Trends for these water levels are assumed to be caused by natural factors, such as changes in recharge from precipitation. Hydrographs of these water levels were grouped by the following hydrologic units: carbonate-rock aquifer, volcanic tuff, and Eleana confining unit (figs. 13-15, respectively). Long-term fluctuations in recharge may cause some of the naturally occurring trends. The magnitude of the overall water-level change for these trends typically is less than $2 \mathrm{ft}$.

Six of the 10 wells open to the carbonate-rock aquifer have significant upward water-level trends, one has a significant downward trend, and three have no significant upward or downward trend (table 8). Of the eight wells with data from 1994 to 2003, all but one well, UE-1q (2600 ft), had a higher mean water level in 2003 than in 1994. Six of the 10 hydrographs have very similar LOWESS trends, which are characterized by a relatively rapid rise in the mid-1990's followed by a gentle rise or a gentle decline after 2000 (fig. 13). Well UE-10j (2232-2297 ft), which is missing data from 1994 to 1996 , probably also has the characteristic pattern of the carbonate-rock hydrographs. Water levels in this well from 1997 to 2003 strongly correlate with levels in well WW-2 (3422 ft). Three of the wells in figure 13 have hydrographs without the characteristic pattern. Hydrographs from two of the wells, UE-1h and ER-6-2, have a strong upward trend from 1994 to 2003. The third well, UE-1q (2600 ft), has a slightly downward trending hydrograph that appears similar 
Table 8. Analysis of water-level trends, using the Mann-Kendall test, for selected wells in the Yucca Flat area

Level of significance (p): Probability that water-level changes are due to chance rather than a trend; <, less than.

Maximum change in water level: A measure of the amount of variation in water level for the period analyzed. The change is the difference between the maximum and minimum water-level values using a LOWESS smooth (figs. 13-15 and 18).

Statistically significant trend: Considered significant if the level of significance is less than 0.01; up, water level rising; down, water level declining; none, no significant monotonic trend for period analyzed.

\begin{tabular}{|c|c|c|c|c|c|c|}
\hline $\begin{array}{c}\text { U.S. Geological Survey } \\
\text { well name } \\
\text { (see fig. 2) }\end{array}$ & $\begin{array}{l}\text { Period of } \\
\text { record } \\
\text { analyzed }\end{array}$ & $\begin{array}{c}\text { Number of } \\
\text { observations }\end{array}$ & $\begin{array}{c}\text { Level of } \\
\text { significance } \\
\text { (p) }\end{array}$ & $\begin{array}{l}\text { Kendall's } \\
\text { tau }\end{array}$ & $\begin{array}{c}\text { Maximum } \\
\text { change in } \\
\text { water level, } \\
\text { in feet } \\
\end{array}$ & $\begin{array}{l}\text { Statistically } \\
\text { significant } \\
\text { trend }\end{array}$ \\
\hline \multicolumn{7}{|c|}{ Carbonate-rock aquifer water levels } \\
\hline ER-3-1-2 (shallow) & 1994-2003 & 38 & 0.002 & -0.35 & 1 & up \\
\hline ER-6-1 main $(2243 \mathrm{ft})$ & 1995-2003 & 32 & 0.002 & -0.40 & 0.9 & up \\
\hline ER-6-1-1 & 1994-2003 & 25 & $<0.001$ & -0.52 & 1 & up \\
\hline ER-6-2 & 1994-2003 & 39 & $<0.001$ & -0.81 & 2.8 & up \\
\hline $\mathrm{U}-3 \mathrm{cn} 5$ & 1994-2003 & 23 & $<0.001$ & -0.57 & 0.8 & up \\
\hline UE-1h & 1994-2003 & 21 & $<0.001$ & -0.86 & 2.3 & up \\
\hline UE-1q (2600 ft) & 1994-2003 & 36 & 0.001 & 0.38 & 0.3 & down \\
\hline $\mathrm{UE}-7 \mathrm{nS}$ & 1994-2003 & 25 & 0.02 & -0.33 & 0.6 & none \\
\hline UE-10j (2232-2297 ft) & 1997-2003 & 25 & 0.16 & 0.20 & 0.4 & none \\
\hline WW-2 (3422 ft) & 1994-2003 & 35 & 0.11 & -0.19 & 1.4 & none \\
\hline \multicolumn{7}{|c|}{ Volcanic-tuff water levels } \\
\hline ER-6-1 (piezometer) & 1995-2003 & 33 & $<0.001$ & 0.65 & 0.7 & down \\
\hline TW-B & 1994-2003 & 34 & 0.04 & 0.25 & 0.3 & none \\
\hline UE-1c & 1994-2003 & 22 & 0.76 & 0.05 & 0.2 & none \\
\hline UE-6e (2090-2230 ft) & 1994-2003 & 32 & 0.05 & -0.24 & 1.5 & none \\
\hline UE-14b & 1994-2003 & 20 & 0.28 & 0.17 & 0.3 & none \\
\hline \multicolumn{7}{|c|}{ Eleana confining unit water levels } \\
\hline ER-12-1 (1641-1846ft) & $1998-2003$ & 23 & $<0.001$ & -0.60 & 1.3 & up \\
\hline TW-D & 1994-2003 & 20 & 0.019 & 0.38 & 0.6 & none \\
\hline UE-1a & 1994-2003 & 22 & 0.5 & -0.10 & 0.1 & none \\
\hline UE-1b & 1994-2003 & 26 & 0.48 & 0.10 & 0.1 & none \\
\hline UE-1L (recompleted) & 1994-2003 & 21 & $<0.001$ & -0.76 & 1.1 & up \\
\hline UE-16f $(1479 \mathrm{ft})$ & 1994-2003 & 25 & 0.002 & -0.44 & 0.2 & up \\
\hline \multicolumn{7}{|c|}{ Water levels affected by withdrawals } \\
\hline UE-2ce & 1994-2003 & 28 & $<0.001$ & 0.88 & 2.5 & down \\
\hline UE-6d & 1985-2003 & 33 & $<0.001$ & -0.72 & 2.2 & up \\
\hline WW-3 (1800 ft) & 1992-2003 & 42 & $<0.001$ & -0.52 & 1.3 & up \\
\hline WW-A (1870 ft) & 1994-2003 & 36 & $<0.001$ & -0.87 & 3.1 & up \\
\hline \multicolumn{7}{|c|}{ Water levels likely affected by nuclear tests } \\
\hline TW-7 & 1980-2003 & 48 & $<0.001$ & 0.98 & 47 & down \\
\hline $\mathrm{U}-2 \mathrm{gk}$ & 1994-2003 & 30 & $<0.001$ & -0.98 & 4.6 & up \\
\hline U-3en PS 2 & 1963-1977 & 29 & $<0.001$ & -0.98 & 350 & up \\
\hline U-4u PS 2a & 1991-1998 & 31 & $<0.001$ & -1.00 & 142 & up \\
\hline U-9ca 1 & 1964-1978 & 16 & $<0.001$ & 0.98 & 161 & down \\
\hline UE-3e 4-1 (2181 ft) & 1990-2003 & 32 & $<0.001$ & 0.73 & 149 & down \\
\hline UE-3e 4-2 (1919ft) & 1990-2003 & 37 & $<0.001$ & 1.00 & 152 & down \\
\hline UE-3e 4-3 (1661 ft) & 1990-2003 & 32 & $<0.001$ & -0.85 & 3.8 & up \\
\hline UE-4t 1 (1906-2010 ft) & 1992-2003 & 41 & $<0.001$ & 1.00 & 208 & down \\
\hline
\end{tabular}


to hydrographs in volcanic tuffs (fig. 14). All three of these wells are in the southwestern part of Yucca Flat, west of the Yucca and Topgallant faults; wells UE-1h and ER-6-2 also are west of the Carpetbag fault (fig. 3). The location of these three wells and their dissimilar hydrographs may indicate that the faults create a flow barrier in the carbonate-rock flow system.

Wells open to volcanic tuffs, and with naturally occurring water-level trends, are in the southern part of the Yucca Flat area. Hydrographs from these wells have a distinctly different pattern from the general water-level pattern of the carbonaterock aquifers. LOWESS trends of hydrographs from wells open to volcanic tuffs generally are characterized by flat to slight-downward trends from 1994 to 2003 (fig. 14). The exception to this pattern, well UE-6e (2090-2230 ft), is characterized by greater measurement variation and an upward trend beginning around 2000. Water levels in four of the wells have no significant upward or downward trend (table 8). Well ER-6-1 (piezometer) is the only well open to volcanic tuffs with a significant downward trend. A possible reason for this downward trend is a suspected breach in the casing that could permit water from the volcanic-tuff open interval in ER-6-1 (piezometer) to drain down to the deeper carbonate-rock open interval in well ER-6-1 main (2243 ft) (Jeffrey Wurtz, StollerNavarro Joint Venture, written commun., 2005).

Wells open to the Eleana confining unit, and with naturally occurring water-level trends, are in the western part of the Yucca Flat area. Hydrographs from these wells are characterized by flat to slight upward trends (fig. 15) and are similar in appearance to water-level trends in the volcanic tuffs. Three wells have statistically significant upward trends (table 8). The somewhat anomalous water-level trend in well ER-12-1 (1641-1846 ft) may result from the unique hydrogeologic setting of this well relative to the other wells in the Eleana confining unit. Although well ER-12-1 (1641-1846 $\mathrm{ft}$ ) is grouped with wells open to the Eleana confining unit, the well actually is open to thrust-faulted Paleozoic dolomite sandwiched between rocks of the Eleana Formation (Russell and others, 1996). The well also is at a high altitude $(5,817 \mathrm{ft}$ above sea level) and lies on the east slope of Rainier Mesa, an area of recharge to Yucca Flat.

Deviations in recharge patterns (wet and dry periods) are a potential cause of some of the long-term changes in water levels. LOWESS trends of annual mean water levels in Yucca Flat were compared to LOWESS trends of cumulative departure from mean annual precipitation (fig. 16). Only wells with more than 20 years of water-level measurements were compared. The Rainier Mesa, Pahranagat Valley, and Spring Mountains precipitation indices represented potential recharge from areas surrounding Yucca Flat. Graphical comparison of water levels to precipitation indicates that water levels in some wells may respond to precipitation with a lag of about 3 years. Hydrographs from wells in the carbonate-rock aquifer (U-3en 5, UE-7nS, and UE-1h) show a stronger apparent correspondence to precipitation patterns than other hydrographs. The remaining hydrographs have more subtle fluctuations, which may or may not correspond with precipitation. Waterlevel data collected prior to 1990 did not compare as well with the precipitation curves because water levels were measured sporadically with less accurate devices. In some cases, one or two water levels are all that define the earliest 5 years on the hydrographs (fig. 16). Because of this, the shape of the water-level curve during the 1980's was sometimes difficult to define.

The water-level trend in well UE-1h, in the southwestern part of Yucca Flat, appears different from most of the other trends in figure 16. This well had an upward-trending hydrograph from 1982 to 2003. The water-level fluctuations in this well might be caused by a combination of two different factors. One factor could be causing a linear rise in water level. This linear rise might be caused by recovery from past pumping in nearby well WW-3 or a local source of recharge from ephemeral streams to the west. Once this linear trend is removed from the hydrograph, the remainder of the fluctuations could be explained by a second factor-a response to recharge from northwestern or northeastern sources (fig. 16).

Alternatively, water levels in well UE-1h could be responding to a precipitation source that is different than the source for most of the other wells in Yucca Flat. The UE-1h hydrograph appears very similar to the cumulative departure curve, shifted forward 4 years, for the Spring Mountains precipitation index (fig. 9). This does not imply that the well is receiving recharge water from the Spring Mountains. Rather, water levels may be responding to a closer precipitation source that has a precipitation pattern similar to the Spring Mountains. As discussed earlier, the water-level response in well UE-1h may indicate that the ground water in the southwestern part of Yucca Flat responds differently from the rest of Yucca Flat.

The approximate 3-year lag time between periods of excess precipitation and a response in water levels seems relatively quick given the long distances (miles) from recharge areas to the measured wells. The apparent discrepancy between lag time and distance might be explained as follows. For precipitation falling in highland areas some distance from Yucca Flat, the lag time includes two components: (1) the time necessary for precipitation to travel through the unsaturated zone and enter the ground-water system, and (2) the time necessary for changes in hydraulic head in recharge areas to be observed in a well as a pressure response in a confined aquifer system (Davis and DeWiest, 1966, p. 46). In many high-altitude areas of southern Nevada, precipitation may infiltrate rapidly through the unsaturated zone because soils are thin, bedrock is fractured, and evapotranspiration rates are low (Flint and others, 2002, p. 194). Even in high-altitude areas where the unsaturated zone is relatively thick, ground-water recharge through fractured volcanic or carbonate rocks may occur in a few years or less (Clebsch, 1961, p. 124; Winograd and others, 1998, p. 90; and Guerin, 2001). In comparison, precipitation in desert basins that typically are not recharge areas may take thousands of years to infiltrate the unsaturated 

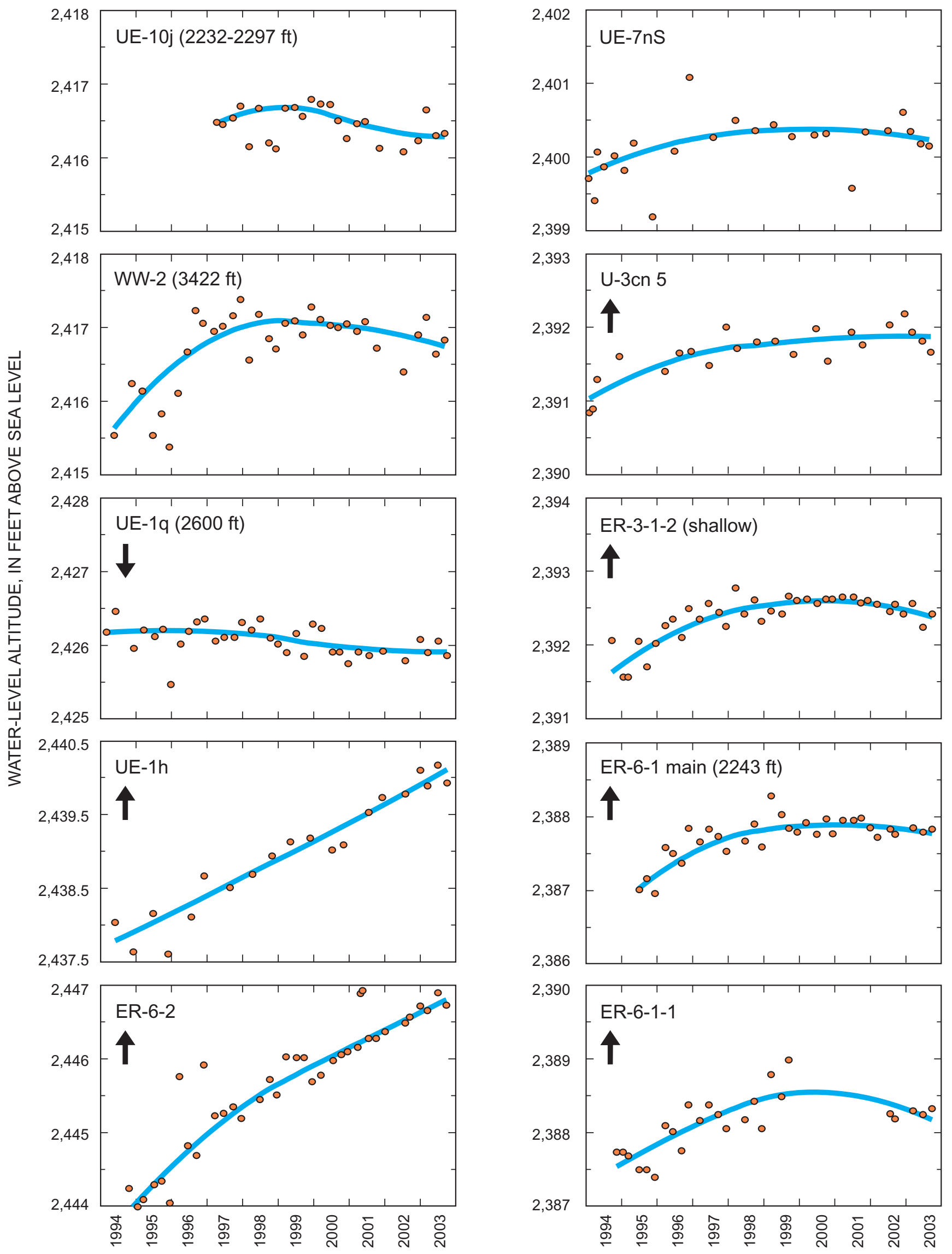

Figure 13. Graphs showing relation among water levels with naturally occurring trends from selected wells in carbonate-rock aquifers, Yucca Flat area, 1994-2003. Blue line is LOWESS trend and arrow indicates direction of statistically significant trend. 

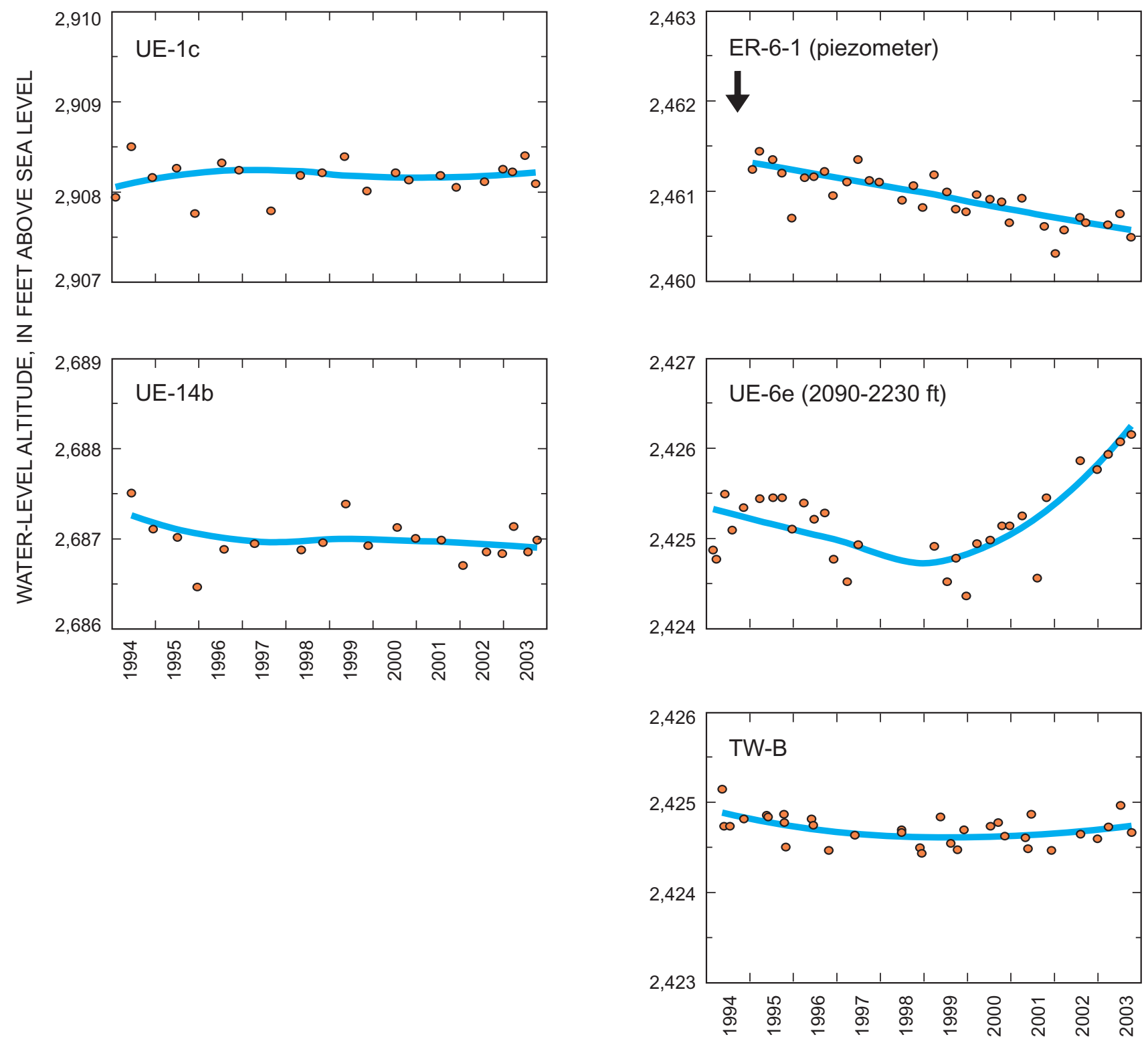

Figure 14. Graphs showing relation among water levels with naturally occurring trends from selected wells in volcanic tuffs, Yucca Flat area, 1994-2003. Blue line is LOWESS trend and arrow indicates direction of statistically significant trend. 

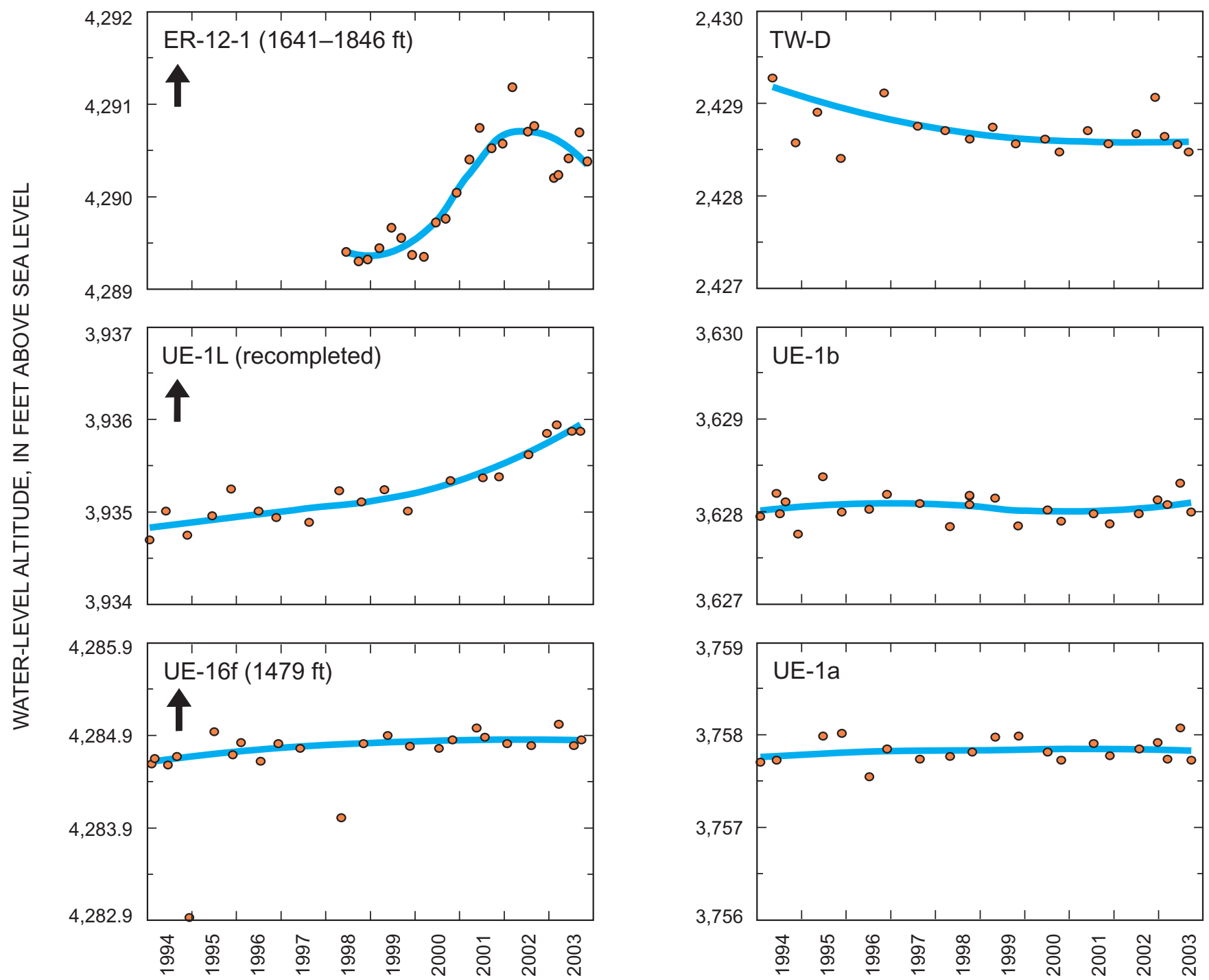

Figure 15. Graphs showing relation among water levels with naturally occurring trends from selected wells in the Eleana confining unit, Yucca Flat area, 1994-2003. Blue line is LOWESS trend and arrow indicates direction of statistically significant trend. 

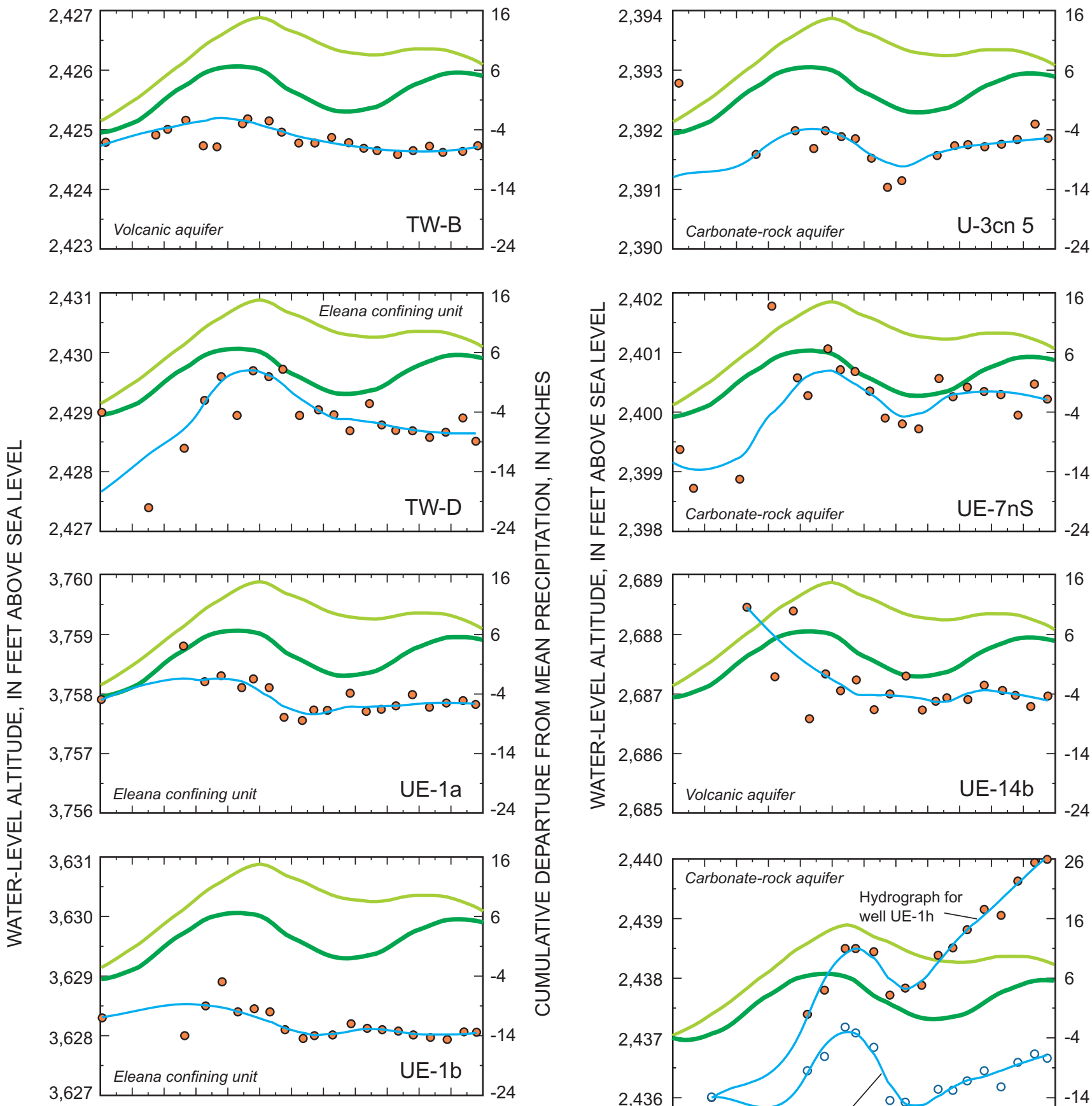

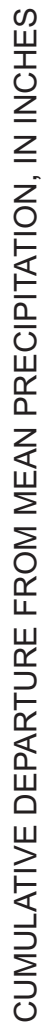

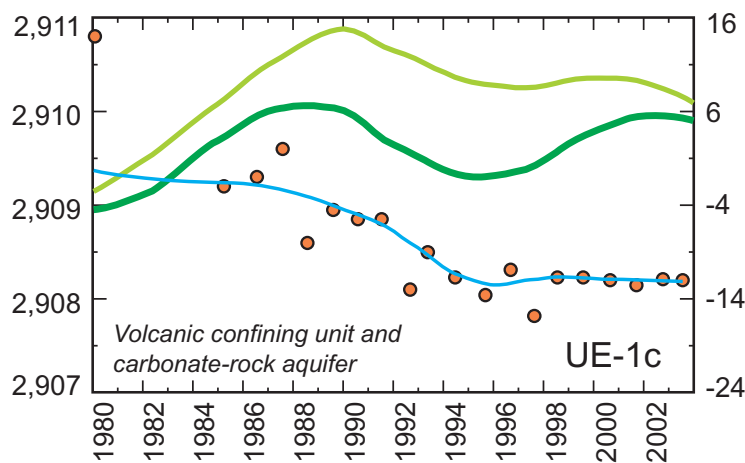

(

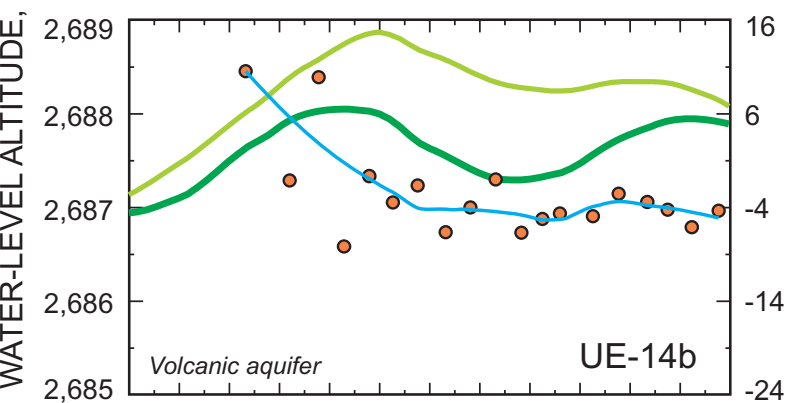

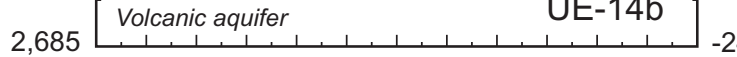

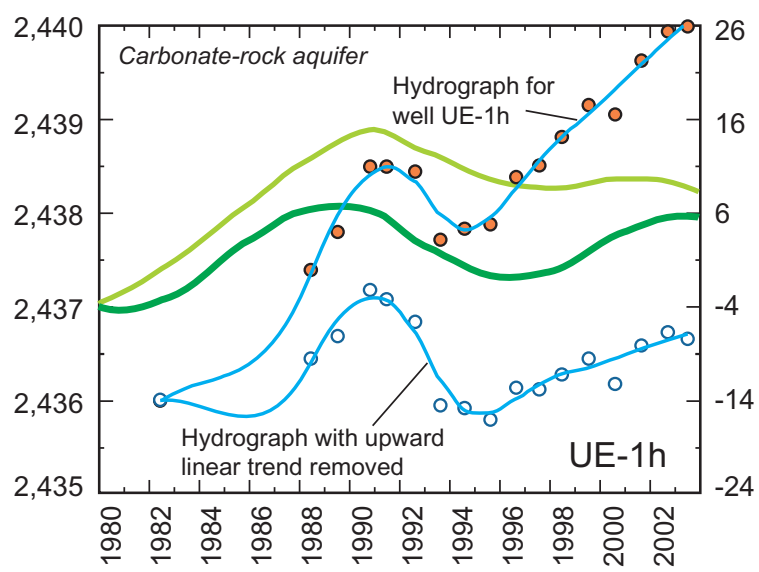

EXPLANATION

oo Smooth of annual mean water-level measurements

Smooth of cumulative departure from mean annual precipitation, 1964-2003

Rainier Mesa precipitation index

Pahranagat Valley precipitation index

Figure 16. Graphs showing relation between trends in precipitation and steady-state water levels from selected wells in the Yucca Flat area, 1980-2003. All precipitation trend lines were shifted forward 3 years except those on plot UE-1h, which were shifted forward 4 years. 
zone (Blout and others, 1995; Tyler and others, 1996). After precipitation reaches the ground-water system, the pressure response in a confined aquifer system may propagate quickly through permeable fractured rocks or slowly through lesspermeable confining units. For example, a pressure response in the carbonate-rock aquifer in Yucca Flat was shown to propagate more than $6 \mathrm{mi}$ in about a day during an aquifer test in well ER-6-1-2 (Stoller-Navarro Joint Venture, written commun., 2005).

The apparent correspondence between precipitation and water-level trends (fig. 16) should be viewed with caution. This is especially true for water-level trends in the volcanic tuffs and Eleana confining unit. Although a plausible case could be made that water levels in the carbonate-rock aquifer are responding to precipitation 3 years after it falls, a short response time in less-permeable units is unlikely. Additionally, water-level trends assumed to be caused by natural climatic processes may be affected by unknown factors, such as distant pumping, problems related to well construction, subsidence, and changing water temperature. Changes in water levels from these unknown factors may be attributed, incorrectly, to a precipitation response. Longer-term water-level records are needed to determine with more certainty whether precipitation is the primary cause of many of the fluctuating water levels in Yucca Flat.

\section{Anthropogenic Trends}

Trends in water levels caused by anthropogenic activities were grouped by the cause of the trend-water withdrawals and nuclear tests (table 8). About 3 percent of the measured water levels in Yucca Flat were affected by water withdrawals from one or more of the nine withdrawal wells in Yucca Flat (fig. 10). Nuclear tests, however, affected about 35 percent of the measured water levels in Yucca Flat. Only levels that were part of a long-term record, affected by nuclear tests, and with a general-condition attribute of "localized conditions" were analyzed for trends. The overall water-level change for wells with anthropogenic trends ranged from about 4 to $350 \mathrm{ft}$.

Water levels in withdrawal wells were measured sporadically when pumped, which limited analysis to six wells (fig. 17). Two of the wells pumping from the carbonaterock aquifer, WW-2 (3422 ft) and WW-C-1, appear to have had relatively little drawdown despite high rates of pumping. Water levels in WW-2 (3422 ft) were interpreted to be fully recovered in 1993, when water-level monitoring in the well began on a regular basis. The quick recovery in these wells indicates a high transmissivity in the carbonate-rock aquifer. Four of the six wells in figure 17 had water-level trends computed for selected periods of the records (table 8). Periods selected for statistical analysis began after pumping had ceased and water levels were recovering or had recovered. Water levels in three of the four wells had significant upward trends, whereas, water levels in the remaining well had a significant downward trend.
The three wells with significant upward water-level trends, following cessation of pumping, were WW-3 (1800 $\mathrm{ft}), \mathrm{UE}-6 \mathrm{~d}$, and WW-A (1870 ft). All three of these wells are open to the valley-fill aquifer and show a prolonged period of recovery following the cessation of pumping. This prolonged period indicates a relatively low transmissivity of the valleyfill aquifer. In WW-3 (1800 ft), about $60 \mathrm{ft}$ of drawdown was recorded. Following the cessation of pumping in 1970, water levels required 27 years to recover. Well UE-6d is an observation well about $0.7 \mathrm{mi}$ from WW-3 (1800 ft). About $14 \mathrm{ft}$ of drawdown was recorded in this well before full recovery in 1999. A total of about $15 \mathrm{ft}$ of drawdown was measured in WW-A (1870 ft). Pumping ended in 1988 and water levels were considered recovered in 2003.

The hydrograph for well UE-2ce is more difficult to explain as being affected solely by pumping. The well is open within a block of fault-thrusted Paleozoic dolomite, which may be isolated from the regional carbonate-rock aquifer (Cole and Cashman, 1999). The well was drilled about $600 \mathrm{ft}$ distant from the 39-kiloton nuclear test, Nash (hole U-2ce), detonated in 1967. The working point for Nash was about 200 $\mathrm{ft}$ above the initial 1977 water level in well UE-2ce. The initial 1977 water level is interpreted as being elevated by the nearby nuclear test. About 34 acre-ft of water was withdrawn from well UE-2ce from 1977 to 1984. Elevated concentrations of tritium were measured repeatedly during the period of pumping (Buddemeier and Isherwood, 1985). After pumping ended in 1984, water levels recovered from pumping through 1994. "Recovered" water levels in 1994 were almost $50 \mathrm{ft}$ lower than the initial water level in the well. A statistically significant water-level decline of about $2 \mathrm{ft}$ occurred from 1994 to 2003 (table 8).

The causes of incomplete recovery and the current decline in well UE-2ce are not clear. The well only was able to sustain pumping rates of less than about $10 \mathrm{gal} / \mathrm{min}$. Incomplete recovery may have been caused by the draining of perched zones during the period of pumping. A more likely explanation is that water levels were affected by the nearby nuclear test, Nash. Possibly, the initial measured water level in well UE-2ce was anomalously high because of the nuclear test, but was in a declining trend as water levels equilibrated after the test. In this scenario, water levels could decline from either (1) pore-water depressurization following the nuclear test, or (2) a drainage effect as water moved away from well UE-2ce toward the Nash test cavity (assuming it extended below the water). Because well UE-2ce was pumped immediately after completion, the hypothetical declining trend from the nuclear test would have been masked by pumping. Following recovery from pumping in 1994, the declining trend from the nuclear test would become apparent.

Nuclear tests affected water levels in many wells. Levels in nine wells that likely were affected by these tests were analyzed for trends (table 8). All wells had highly significant $(\mathrm{p}<0.001)$ trends, with four wells having upward trends and five wells having downward trends. These trends are attributed 

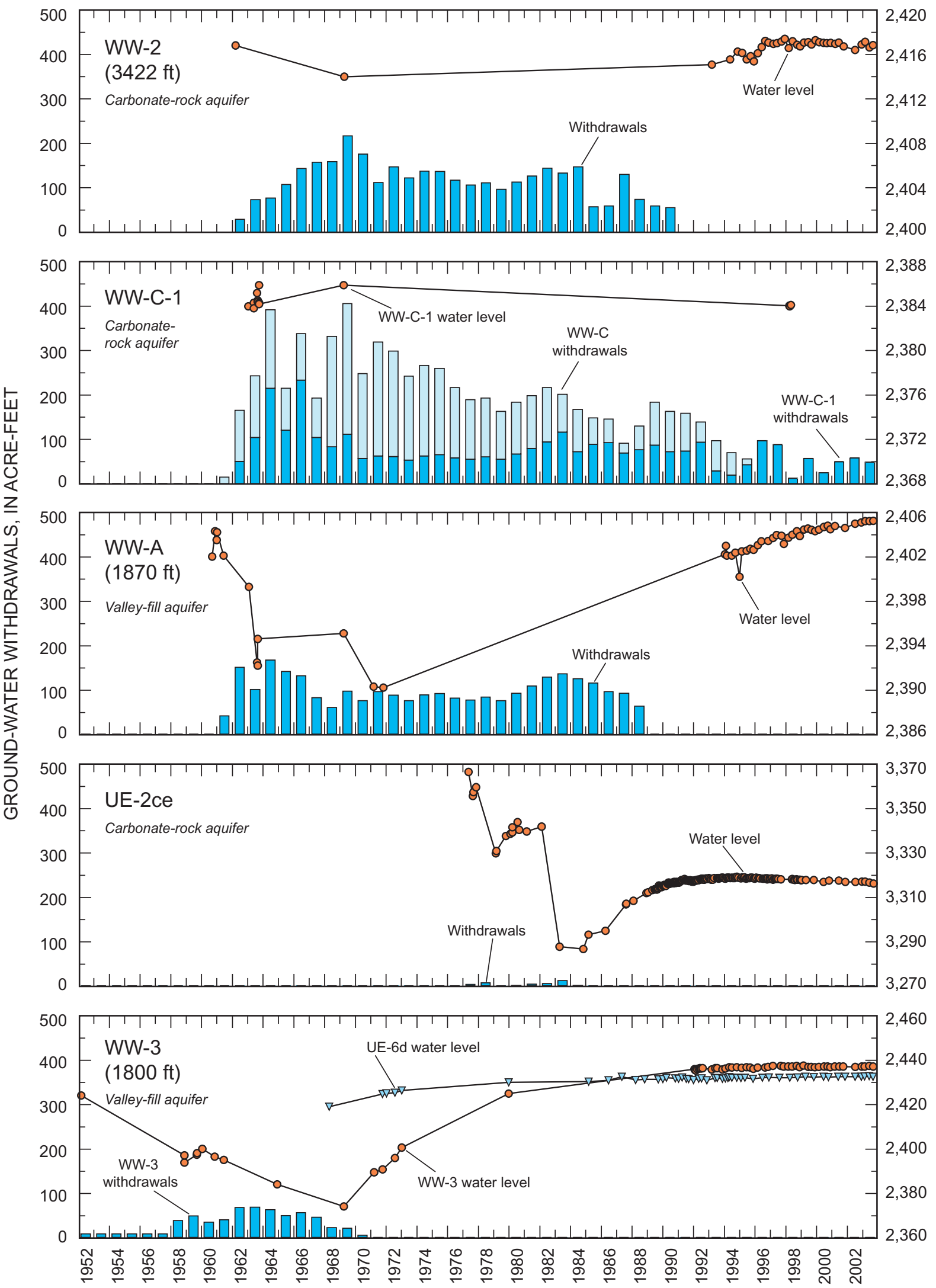

Figure 17. Graphs showing relation between ground-water withdrawals and water levels from selected wells affected by withdrawals in Yucca Flat, 1952-2003. Note that vertical scales on water-level axes are not consistent. 
to test-cavity infilling or the effects of depressurization following nuclear testing.

Hydrographs for wells U-3cn PS 2 and U-4u PS 2A (fig. 18) are two examples of rising trends from cavity infilling following nuclear tests. These wells were drilled into the cavities formed by the Bilby and Dalhart nuclear tests, detonated September 13, 1963, and October 13, 1988, respectively. Water levels in the wells rose 140 to $350 \mathrm{ft}$ during a period of 7-14 years. In the case of well U-3cn PS 2, the final water level measured in the well is about $40 \mathrm{ft}$ higher than the pretest water levels in nearby wells U-3cn $1, \mathrm{U}-3 \mathrm{cn} 3$, and U-3en 4 HTH.

Water levels from tuffs in well TW-7 show the effects of pore-water pressurization and depressurization caused by nearby nuclear testing. Water levels were elevated about $100 \mathrm{ft}$ by multiple nearby tests (figs. 7 and 18). Fifteen years after the last nearby test, water levels still were equilibrating and appear to be stabilizing at a head that is about $15-20 \mathrm{ft}$ higher than pretest heads. This higher equilibration level may result from (1) a redistribution of heads caused by a change in the local hydraulic properties from nuclear testing and (2) an unaccounted-for lowering of the measuring-point altitude through subsidence or a shifted casing.

Declining trends in wells UE-4t 1 (1906-2010 ft), U-9ca 1, UE-3e 4-1 (2181 ft), and UE-3e 4-2 (1919ft) are interpreted as dissipations of pressures in over-pressurized zones as water moves toward zones of lower pressure (fig. 18). Water-level declines in these wells ranged from 149 to $208 \mathrm{ft}$ over the periods of records. Rising trends in wells UE-3e 4-3 (1661 ft) and U-2gk may result from water migrating from confined, high-pressure zones to areas of unconfined conditions. The magnitude of the water-level rise in these water-table wells was no more than $5 \mathrm{ft}$.

\section{Vertical Water-Level Differences}

Vertical water-level differences at 27 sites in Yucca Flat with multiple open intervals were compared (fig. 19; table 9). At each site, the vertical difference in water levels between two open intervals was calculated to determine if water had the potential to move vertically at a site. Some of these sites had three or more water levels, each from a different open-interval depth, which allowed for more than one vertical difference to be analyzed at the site. Vertical hydraulic gradients were not calculated in this analysis because of uncertainties in estimating the vertical distance separating two head measurements. The top, bottom, and midpoint of each open interval and the water level that was chosen to represent each open interval are listed in table 9.

Water levels from multiple open intervals at a single site were obtained under various conditions. In some cases, water levels were measured from multiple wells at a site that were completed at different depths. At other sites, a packer was installed to measure discrete open intervals in an open borehole or in a well with multiple open intervals. Finally, at some sites, the borehole was recompleted by deepening, plugging back, or adding a bridge plug or well casing. In these boreholes, water levels were measured before and after the recompletion to obtain measurements at different open intervals.

In many cases, vertical water-level differences from two different dates were compared (table 9). However, only water levels that had equilibrated or nearly equilibrated to the conditions in the aquifer were used in the analysis. Water levels from different dates were used only if the vertical difference was greater than the temporal variability.

Results of the analysis of vertical water-level differences between open intervals are shown in figure 19. The difference commonly is shown with an approximate sign $(\sim)$ or a less than $(<)$ or greater than $(>)$ sign. These signs are used to indicate that the water-level differences are approximate. These approximations occur in instances where the water-level measurements are from two different dates or where one of the water levels was nearly, but not fully, equilibrated. In general, figure 19 can be used to determine general areas where water has the potential to move upward or downward in Yucca Flat. Several generalizations, listed below, can be made from figure 19:

1. In boreholes where water levels were affected by nuclear tests, vertical water-level differences are large (greater than $100 \mathrm{ft}$ of head difference). All five boreholes (ER-2-1, UE-3e, UE-3e 4, UE-3mf, and UE-4t) in which water levels were affected by nuclear tests had upward hydraulic gradients with large vertical water-level differences.

2. Vertical water-level differences within the carbonaterock aquifers generally are small. Six of the seven boreholes (ER-3-1, ER-6-1, UE10j, UE-15d WW, UE-16d WW, and WW-2) that have open intervals at different depths within carbonate rocks have water-level differences of less than $5 \mathrm{ft}$. The exception is borehole TW-E, which has a relatively large vertical water-level difference and a downward hydraulic gradient.

3. The observed vertical water-level difference within the valley-fill aquifer also is small. The one borehole (WW-A) that has open intervals at different depths within valley fill has a vertical water-level difference of less than $5 \mathrm{ft}$.

4. The potential for water to move between two intervals of volcanic rocks or between volcanic rocks overlying carbonate rocks in areas not affected by nuclear tests generally is downward. Of the 14 cases that were examined, gradients were downward between 11 interval pairs (boreholes ER-6-1, ER-6-1-2, TW-E, UE-4a, UE-4av, UE-1q, UE-8e, UE-10 ITS 3, UE-10 ITS 5, and WW-2 with two intervals pairs). Most of the downward vertical water-level differences were greater than $50 \mathrm{ft}$. In the remaining three interval pairs (boreholes UE-4ae, UE-6e, and U-7ad), vertical water-level differences of less than $10 \mathrm{ft}$ were too small to quantify.

5. The direction of the vertical hydraulic gradient generally is from pre-Tertiary clastic rocks toward volcanic- or carbonate-rock units. In the four boreholes with pre-Tertiary clastic rocks, gradients were upward from the clastic rocks to volcanic or carbonate rocks in three boreholes (ER-12-2, 

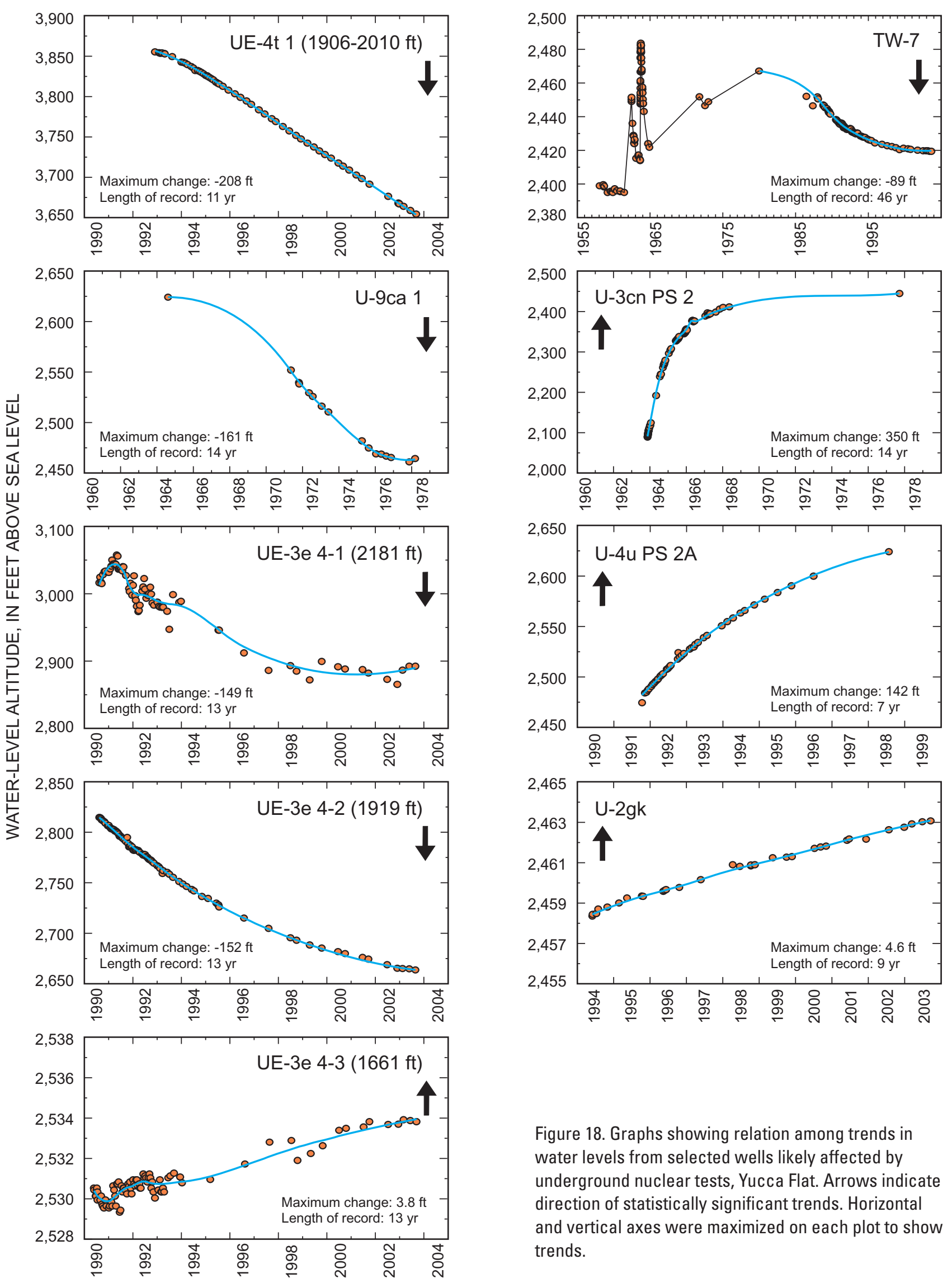

Figure 18. Graphs showing relation among trends in water levels from selected wells likely affected by underground nuclear tests, Yucca Flat. Arrows indicate direction of statistically significant trends. Horizontal and vertical axes were maximized on each plot to show trends. 


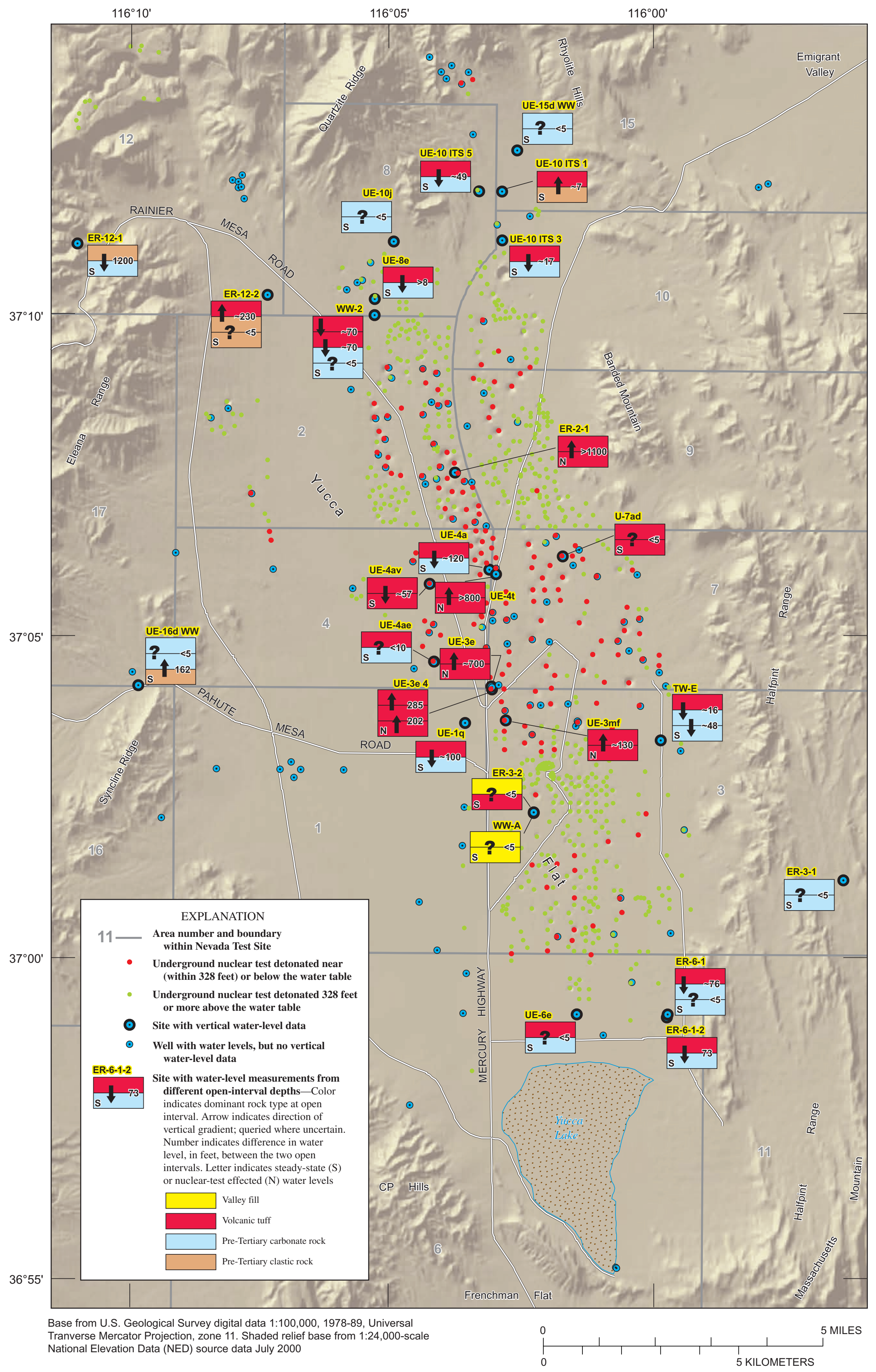

Figure 19. Map showing vertical water-level differences, direction of vertical ground-water gradients, and location of underground nuclear tests in the Yucca Flat area, Nevada Test Site. Data for vertical water-level differences are listed in table 9 
(Blank page for duplexing oversized figure.) 
Table 9. Open-interval and water-level data for selected wells used to analyze vertical water-level differences in the Yucca Flat area

Open interval: Area of saturated opening in well where ground water may enter. Open interval consists of open borehole and(or) well screen. Where opening extends above the water level in the well, the top of the water is considered the top of the open interval. Midpoint is calculated as the average of the top and bottom depths. Depth is in feet below land surface.

Contributing units: Lithologic unit(s) contributing water to well. Multiple units for a single well are listed in the order of their likely importance in contributing water to the well. Abbreviations: C, pre-Tertiary carbonate rock; F, valley fill; P, Paleocolluvium; S, pre-Tertiary clastic rock; V, volcanic tuffs; $\mathrm{X}$, igneous or metamorphic rocks.

Water level: Water-level measurement that was used for analysis of vertical water-level differences; depth relative to land surface; altitude relative to sea level. Symbols: <, less than; > greater than; , approximately.

\begin{tabular}{|c|c|c|c|c|c|c|c|}
\hline \multirow{2}{*}{$\begin{array}{l}\text { U.S. Geological Survey } \\
\text { well name } \\
\text { (see fig. 2) }\end{array}$} & \multicolumn{3}{|c|}{ Depth to open interval (feet) } & \multirow{2}{*}{$\begin{array}{c}\text { Contributing } \\
\text { units }\end{array}$} & \multicolumn{3}{|c|}{ Water level } \\
\hline & Top & Bottom & Midpoint & & Date & $\begin{array}{l}\text { Depth } \\
\text { (feet) }\end{array}$ & $\begin{array}{c}\text { Altitude } \\
\text { (feet) }\end{array}$ \\
\hline ER-2-1 (2079 ft) & 1,725 & 2,177 & 1,951 & $\mathrm{~V}$ & $11 / 12 / 2003$ & 1,725 & 2,491 \\
\hline ER-2-1 $(2559 \mathrm{ft})$ & 2,313 & 2,600 & 2,457 & $\mathrm{~V}$ & $11 / 12 / 2003$ & 601 & 3,614 \\
\hline ER-3-1-2 (shallow) & 2,208 & 2,310 & 2,259 & $\mathrm{C}$ & $6 / 26 / 1995$ & $2,016.04$ & $2,390.70$ \\
\hline ER-3-1-1 (deep) & 2,512 & 2,807 & 2,660 & $\mathrm{C}$ & $6 / 26 / 1995$ & $2,015.99$ & $2,390.75$ \\
\hline ER-3-2-2 (middle) & 2,588 & 2,636 & 2,612 & $\mathrm{~F}, \mathrm{~V}$ & $3 / 13 / 1997$ & 1,605 & 2,405 \\
\hline ER-3-2-1 (deep) & 2,860 & 3,000 & 2,930 & $\mathrm{~V}$ & $6 / 26 / 1995$ & 1,606 & 2,404 \\
\hline ER-6-1 (piezometer) & 1,473 & 1,542 & 1,508 & $\mathrm{~V}$ & 1/9/1995 & 1,473 & 2,464 \\
\hline ER-6-1 main $(2129 \mathrm{ft})$ & 1,819 & 2,129 & 1,974 & $\mathrm{C}$ & $11 / 19 / 1992$ & 1,549 & 2,388 \\
\hline ER-6-1 main $(3206 \mathrm{ft})$ & 1,819 & 3,206 & 2,513 & $\mathrm{C}$ & $1 / 9 / 1995$ & 1,548 & 2,389 \\
\hline ER-6-1-2 (1587ft) & 1,472 & 1,587 & 1,529 & V & $9 / 24 / 2003$ & 1,472 & 2,464 \\
\hline ER-6-1-2 (3200 ft) & 1,775 & 3,200 & 2,488 & $\mathrm{C}, \mathrm{X}$ & $9 / 24 / 2003$ & 1,545 & 2,390 \\
\hline ER-12-1 (1641-1846ft) & 1,641 & 1,846 & 1,744 & $\mathrm{C}, \mathrm{S}, \mathrm{X}$ & $3 / 7 / 1995$ & 1,534 & 4,283 \\
\hline ER-12-1 (3309-3414 ft) & 3,309 & 3,442 & 3,376 & $\mathrm{C}$ & 9/25/1992 & 2,762 & 3,055 \\
\hline ER-12-2 (579 ft) & 415 & 650 & 533 & $\mathrm{~V}, \mathrm{~F}, \mathrm{~S}$ & $11 / 11 / 2003$ & 414 & 4,290 \\
\hline ER-12-2 (2964-5203ft) & 2,964 & 5,203 & 4,084 & $S, X$ & $11 / 11 / 2003$ & 187 & 4,518 \\
\hline ER-12-2 (5203-6883 ft) & 5,203 & 6,883 & 6,043 & S, X & $11 / 11 / 2003$ & 186 & 4,518 \\
\hline TW-E (1970 ft) & 1,716 & 1,970 & 1,843 & $\mathrm{~V}$ & $11 / 30 / 1960$ & 1,716 & 2,456 \\
\hline TW-E (2430 ft) & 1,732 & 2,430 & 2,081 & $\mathrm{C}, \mathrm{V}$ & $6 / 20 / 1961$ & 1,732 & 2,440 \\
\hline TW-E (2620 ft) & 1,780 & 2,620 & 2,200 & $\mathrm{C}, \mathrm{V}$ & $9 / 6 / 1963$ & 1,780 & 2,392 \\
\hline U-7ad (1853 ft) & 1,819 & 1,853 & 1,836 & V & $10 / 28 / 1972$ & 1,819 & 2,467 \\
\hline U-7ad (1965 ft) & 1,820 & 1,965 & 1,893 & $\mathrm{~V}$ & $11 / 2 / 1972$ & 1,820 & 2,466 \\
\hline UE-1q (2437 ft) & 1,553 & 2,437 & 1,995 & $\mathrm{~V}, \mathrm{C}$ & 9/17/1991 & 1,553 & 2,528 \\
\hline $\mathrm{UE}-1 \mathrm{q}(2600 \mathrm{ft})$ & 2,459 & 2,600 & 2,530 & $\mathrm{C}$ & $6 / 4 / 1992$ & 1,655 & 2,426 \\
\hline UE-3e (1707 ft) & 1,557 & 1,707 & 1,632 & $\mathrm{~V}$ & $6 / 24 / 1986$ & 1,557 & 2,526 \\
\hline UE-3e $(2118-2510 \mathrm{ft})$ & 2,118 & 2,510 & 2,314 & $\mathrm{~V}$ & $8 / 18 / 1986$ & $<838$ & $>3,245$ \\
\hline UE-3e 4-3 (1661 ft) & 1,552 & 1,668 & 1,610 & $\mathrm{~V}$ & $8 / 28 / 1990$ & 1,552 & 2,529 \\
\hline UE-3e 4-2 (1919ft) & 1,832 & 1,926 & 1,879 & $\mathrm{~V}$ & $8 / 28 / 1990$ & 1,268 & 2,814 \\
\hline UE-3e $4-1(2181 \mathrm{ft})$ & 2,094 & 2,192 & 2,143 & $\mathrm{~V}$ & $8 / 28 / 1990$ & 1,065 & 3,016 \\
\hline UE-3mf (119-1692ft) & 1,482 & 1,692 & 1,587 & $\mathrm{~V}$ & $5 / 21 / 1987$ & 1,482 & 2,584 \\
\hline UE-3mf (1894-2395 ft) & 1,894 & 2,395 & 2,145 & $\mathrm{~V}$ & $11 / 8 / 1986$ & 1,359 & 2,707 \\
\hline UE-4a (2655 ft) & 1,620 & 2,655 & 2,137 & $\mathrm{~V}$ & $6 / 4 / 1963$ & 1,620 & 2,535 \\
\hline UE-4a (3028ft) & 2,886 & 3,028 & 2,957 & $\mathrm{C}, \mathrm{P}, \mathrm{V}$ & $11 / 18 / 1961$ & 1,740 & 2,415 \\
\hline UE-4ae (2290 ft) & 1,634 & 2,290 & 1,962 & V & $8 / 18 / 1976$ & 1,634 & 2,496 \\
\hline UE-4ae (2457 ft) & 1,628 & 2,457 & 2,043 & $\mathrm{C}, \mathrm{V}$ & $5 / 27 / 1974$ & 1,628 & 2,502 \\
\hline UE-4av (1758 ft) & 1,569 & 1,758 & 1,664 & $\mathrm{~V}$ & 7/7/1989 & 1,569 & 2,608 \\
\hline UE-4av (1724-2815 ft) & 1,724 & 2,815 & 2,270 & $\mathrm{~V}, \mathrm{P}, \mathrm{S}$ & $7 / 11 / 1990$ & 1,626 & 2,551 \\
\hline
\end{tabular}


Table 9. Open-interval and water-level data for selected wells used to analyze vertical water-level differences in the Yucca Flat area-Continued

\begin{tabular}{|c|c|c|c|c|c|c|c|}
\hline \multirow{2}{*}{$\begin{array}{l}\text { U.S. Geological Survey } \\
\text { well name } \\
\text { (see fig. 2) }\end{array}$} & \multicolumn{3}{|c|}{ Depth to open interval (feet) } & \multirow{2}{*}{$\begin{array}{l}\text { Contributing } \\
\text { units }\end{array}$} & \multicolumn{3}{|c|}{ Water level } \\
\hline & Top & Bottom & Midpoint & & Date & $\begin{array}{l}\text { Depth } \\
\text { (feet) }\end{array}$ & $\begin{array}{c}\text { Altitude } \\
\text { (feet) }\end{array}$ \\
\hline $\begin{array}{l}\text { UE-4t } 2(1564-1754 \text { ft) } \\
\text { UE-4t } 1 \text { (1906-2010ft) }\end{array}$ & $\begin{array}{l}1,564 \\
1,906\end{array}$ & $\begin{array}{l}1,754 \\
2,010\end{array}$ & $\begin{array}{l}1,659 \\
1,958\end{array}$ & $\begin{array}{l}\mathrm{V} \\
\mathrm{V}\end{array}$ & $\begin{array}{l}5 / 19 / 1995 \\
5 / 1 / 1995\end{array}$ & $\begin{array}{r}1,185 \\
323\end{array}$ & $\begin{array}{l}2,956 \\
3,818\end{array}$ \\
\hline $\begin{array}{l}\text { UE-6e (2090-2230 ft) } \\
\text { UE-6e (2090-4209ft) }\end{array}$ & $\begin{array}{l}2,090 \\
2,090\end{array}$ & $\begin{array}{l}2,230 \\
4,209\end{array}$ & $\begin{array}{l}2,160 \\
3,150\end{array}$ & $\begin{array}{l}\mathrm{V} \\
\mathrm{C}, \mathrm{V}\end{array}$ & $\begin{array}{l}\text { 2/9/1994 } \\
5 / 18 / 1992\end{array}$ & $\begin{array}{l}1,511 \\
1,509\end{array}$ & $\begin{array}{l}2,427 \\
2,429\end{array}$ \\
\hline $\begin{array}{l}\text { UE-8e (2295 ft) } \\
\text { UE-8e (2470 ft) }\end{array}$ & $\begin{array}{l}1,880 \\
1,912\end{array}$ & $\begin{array}{l}2,121 \\
2,470\end{array}$ & $\begin{array}{l}2,001 \\
2,191\end{array}$ & $\begin{array}{l}\mathrm{V} \\
\mathrm{C}, \mathrm{V}\end{array}$ & $\begin{array}{l}10 / 20 / 1971 \\
4 / 11 / 1975\end{array}$ & $\begin{array}{r}<1,904 \\
1,912\end{array}$ & $\begin{array}{r}>2,585 \\
2,577\end{array}$ \\
\hline $\begin{array}{l}\text { UE-10 ITS } 1 \text { (2040 ft) } \\
\text { UE-10 ITS } 1\end{array}$ & $\begin{array}{l}1,222 \\
1,215\end{array}$ & $\begin{array}{l}2,040 \\
2,289\end{array}$ & $\begin{array}{l}1,631 \\
1,752\end{array}$ & $\begin{array}{l}\text { V } \\
\text { V, S }\end{array}$ & $\begin{array}{l}1 / 23 / 1978 \\
10 / 28 / 1972\end{array}$ & $\begin{array}{l}1,222 \\
1,215\end{array}$ & $\begin{array}{l}3,264 \\
3,271\end{array}$ \\
\hline $\begin{array}{l}\text { UE-10 ITS } 3 \text { (1926 ft) } \\
\text { UE-10 ITS } 3 \text { (2160 ft) }\end{array}$ & $\begin{array}{l}1,850 \\
1,867\end{array}$ & $\begin{array}{l}1,926 \\
2,160\end{array}$ & $\begin{array}{l}1,888 \\
2,014\end{array}$ & $\begin{array}{l}\mathrm{V} \\
\mathrm{C}, \mathrm{V}\end{array}$ & $\begin{array}{l}3 / 19 / 1985 \\
12 / 5 / 1970\end{array}$ & $\begin{array}{l}1,850 \\
1,867\end{array}$ & $\begin{array}{l}2,503 \\
2,486\end{array}$ \\
\hline $\begin{array}{l}\text { UE-10 ITS } 5 \text { (2180 ft) } \\
\text { UE-10 ITS } 5\end{array}$ & $\begin{array}{l}1,990 \\
2,039\end{array}$ & $\begin{array}{l}2,180 \\
2,334\end{array}$ & $\begin{array}{l}2,085 \\
2,187\end{array}$ & $\begin{array}{l}\mathrm{V} \\
\mathrm{C}, \mathrm{V}\end{array}$ & $\begin{array}{l}\text { 3/16/1973 } \\
8 / 4 / 1972\end{array}$ & $\begin{array}{l}1,990 \\
2,039\end{array}$ & $\begin{array}{l}2,532 \\
2,483\end{array}$ \\
\hline $\begin{array}{l}\text { UE-10j (2232-2297 ft) } \\
\text { UE-10j (2232-2613 ft) }\end{array}$ & $\begin{array}{l}2,232 \\
2,232\end{array}$ & $\begin{array}{l}2,297 \\
2,613\end{array}$ & $\begin{array}{l}2,265 \\
2,423\end{array}$ & $\begin{array}{l}\mathrm{C} \\
\mathrm{C}\end{array}$ & $\begin{array}{l}4 / 8 / 1997 \\
11 / 19 / 1996\end{array}$ & $\begin{array}{l}2,157 \\
2,157\end{array}$ & $\begin{array}{l}2,416 \\
2,417\end{array}$ \\
\hline $\begin{array}{l}\text { UE-15d WW (1735-6001 ft) } \\
\text { UE-15d WW (5400-6001 ft) }\end{array}$ & $\begin{array}{l}1,735 \\
5,400\end{array}$ & $\begin{array}{l}6,001 \\
6,001\end{array}$ & $\begin{array}{l}3,868 \\
5,701\end{array}$ & $\begin{array}{l}\mathrm{C}, \mathrm{X} \\
\mathrm{C}\end{array}$ & $\begin{array}{l}3 / 28 / 1962 \\
10 / 2 / 1963\end{array}$ & $\begin{array}{l}669 \\
667\end{array}$ & $\begin{array}{l}3,918 \\
3,919\end{array}$ \\
\hline $\begin{array}{l}\text { UE-16d WW (830 ft) } \\
\text { UE-16d WW } \\
\text { UE-16d WW (2117-2293 ft) }\end{array}$ & $\begin{array}{r}753 \\
753 \\
2,117\end{array}$ & $\begin{array}{r}830 \\
1,944 \\
2,293\end{array}$ & $\begin{array}{r}792 \\
1,349 \\
2,205\end{array}$ & $\begin{array}{l}\text { C, S, X } \\
\text { C, S, X } \\
\text { S, X }\end{array}$ & $\begin{array}{l}5 / 23 / 1977 \\
3 / 4 / 1981 \\
7 / 9 / 1977\end{array}$ & $\begin{array}{l}753 \\
753 \\
591\end{array}$ & $\begin{array}{l}3,931 \\
3,931 \\
4,093\end{array}$ \\
\hline $\begin{array}{l}\text { WW-2 (2045 ft) } \\
\text { WW-2 (2535ft) } \\
\text { WW-2 (2896ft) } \\
\text { WW-2 (3422ft) }\end{array}$ & $\begin{array}{l}1,915 \\
2,121 \\
2,550 \\
2,700\end{array}$ & $\begin{array}{l}2,045 \\
2,535 \\
2,896 \\
3,412\end{array}$ & $\begin{array}{l}1,980 \\
2,328 \\
2,723 \\
3,056\end{array}$ & $\begin{array}{l}\text { V } \\
\text { V } \\
\text { C } \\
\text { C }\end{array}$ & $\begin{array}{l}3 / 28 / 1961 \\
10 / 23 / 1961 \\
1 / 15 / 1962 \\
3 / 15 / 1993\end{array}$ & $\begin{array}{r}1,915 \\
\sim 1,985 \\
2,056 \\
2,055\end{array}$ & $\begin{array}{r}2,555 \\
\sim 2,485 \\
2,414 \\
2,415\end{array}$ \\
\hline $\begin{array}{l}\text { WW-A (1730 ft) } \\
\text { WW-A (1870 ft) }\end{array}$ & $\begin{array}{l}1,604 \\
1,604\end{array}$ & $\begin{array}{l}1,730 \\
1,870\end{array}$ & $\begin{array}{l}1,667 \\
1,737\end{array}$ & $\begin{array}{l}\mathrm{F} \\
\mathrm{F}\end{array}$ & $\begin{array}{l}8 / 28 / 1960 \\
9 / 20 / 1960\end{array}$ & $\begin{array}{l}1,604 \\
1,604\end{array}$ & $\begin{array}{l}2,403 \\
2,402\end{array}$ \\
\hline
\end{tabular}


UE-10 ITS 1, and UE-16d WW) and downward from clastic rocks to carbonate rocks in the fourth borehole (ER-12-1). In these boreholes, water-level differences generally were large; borehole ER-12-1 had a difference of about 1,200 ft between the clastic rocks and the carbonate rocks below.

\section{Summary}

Yucca Flat is in the northeastern part of the NTS in Nye County, southern Nevada. During the period 1951-92, 659 underground nuclear tests were detonated in Yucca Flat; 138 of these tests were considered certain or probable of introducing radionuclide contaminants into the ground water. The U.S. Department of Energy, National Nuclear Security Administration/Nevada Site Office, under its Environmental Restoration Program, has a long-term program to investigate and remediate radionuclide contaminants generated on the NTS. As part of the program, the USGS is compiling and analyzing available ground-water levels in Yucca Flat.

This report documents the analysis of almost 4,000 water-level measurements made in 216 wells in Yucca Flat and vicinity from 1951 to 2003 . The earliest measurement was made in 1951, whereas, 48 wells were measured in 2003. The shallowest and deepest measured depths to water were 8 and 2,762 ft. Water-level depths of greater than 1,500 ft were measured in 149 wells.

As part of the water-level analysis, a systematic qualityassurance review of the USGS NWIS database was done to remove or correct erroneous water-level data, remove duplicate sites, and add missing water-level measurements. Ancillary data pertinent to computing hydraulic heads in wells also were compiled. These data include well-completion records, borehole deviations, measuring points, and water temperatures, as well as information on units contributing water to the open interval. Reported ground-water withdrawals within the study area and precipitation data from major recharge areas near the Spring Mountains, Rainier Mesa, and Pahranagat Valley also were compiled.

An interpretive Microsoft ${ }^{\circledR}$ Access database of Yucca Flat water levels was constructed. The database consists of several components, including (1) site information for each well, (2) well-construction records, (3) borehole lithology and aquifer data, and (4) water-level data. As part of the database, each water-level measurement was assigned multiple attributes to describe the hydrologic conditions at the time of measurement. Additionally, the database includes narratives that discuss the water levels and hydrograph for each well.

Water levels in 34 wells with long-term data were analyzed for variability and for significant trends. Trends were analyzed statistically to detect significant upward or downward changes. An attempt was made to identify the cause of many of the water-level fluctuations or trends. Potential causes include equilibration following well construction or development, pumping in the monitoring well, withdrawals from a nearby supply well, recharge from precipitation, earthquakes, underground nuclear tests, land subsidence, barometric pressure, and Earth tides.

Changes in barometric pressure and Earth tides cause water-level fluctuations in wells throughout Yucca Flat. These fluctuations typically are largest in wells open to confined aquifers. The combined water-level response from barometric pressure and Earth tides is less than $1 \mathrm{ft}$ and causes daily to annual fluctuations.

About 17,000 acre-ft of water were pumped from nine wells in Yucca Flat between 1952 and 2003; five of these wells pumped more than 2,000 acre-ft each. Annual withdrawals in Yucca Flat peaked in 1969 at about 860 acre-ft/yr and then slowly declined to about 140 acre-ft/yr in 2003. Eighty percent of the water withdrawn in Yucca Flat was from carbonate-rock aquifers; the remaining water was derived from the valley-fill aquifer.

Water-level measurements that represent long-term, regional, steady-state conditions accounted for 37 percent of the water levels measured in Yucca Flat. Trends for these water levels are assumed to be caused by natural processes, such as changes in recharge from precipitation. The magnitude of the overall water-level change for these trends typically is less than $2 \mathrm{ft}$.

Trends were analyzed in 21 wells where water levels responded to natural processes. LOWESS trends of hydrographs from 7 of the 10 wells open to carbonate rock have a very similar pattern characterized by a relatively rapid rise in the mid-1990's followed by a gentle rise or a gentle decline after 2000. The three wells without the characteristic pattern are in the southwestern part of Yucca Flat, west of the Yucca and Topgallant faults. Hydrographs from wells open to volcanic tuffs or the Eleana confining unit have a distinctly different pattern from the general water-level pattern of the carbonate-rock aquifers. In general, LOWESS trends from these wells are characterized by flat to slight downward trends from 1994 to 2003. Graphical comparison of water levels to precipitation indicates that water levels in some wells in the carbonate-rock aquifer respond to precipitation with about a 3-year lag.

Water-level trends that result from anthropogenic activities were caused primarily by water withdrawals and nuclear testing. About 3 percent of the measured water levels in Yucca Flat were affected by water withdrawals; however, nuclear test effects accounted for 35 percent of the measured water levels. The overall water-level change for wells with anthropogenic trends ranged from about 4 to $350 \mathrm{ft}$.

Most of the water-level effects from withdrawals were noted in the withdrawal wells. Two of the wells, WW-2 (3422 ft) and WW-C-1, appear to have had relatively little drawdown despite high rates of pumping. The quick recovery in these wells indicates a high transmissivity in the carbonate-rock aquifer. In wells WW-3 and WW-A, about $60 \mathrm{ft}$ and $15 \mathrm{ft}$ of drawdown, respectively, were recorded. 
Nuclear tests affected water levels in many wells. Levels in nine wells that likely were affected by these tests were analyzed for trends. All wells had highly significant $(\mathrm{p}<0.001)$ trends, with four wells having upward trends and five wells having downward trends. These trends are attributed to testcavity infilling or the effects of depressurization following nuclear testing.

Vertical water-level differences at 27 sites with multiple open intervals in Yucca Flat were compared. Large vertical water-level differences (greater than $100 \mathrm{ft}$ of head difference) were noted in boreholes where water levels were affected by nuclear tests. Vertical water-level differences within the carbonate-rock and valley-fill aquifers generally are small (less than $5 \mathrm{ft}$ of head difference). Vertical hydraulic gradients in volcanic rocks generally are downward and water-level differences commonly are greater than $50 \mathrm{ft}$.

\section{References Cited}

Air Resources Laboratory, Special Operations and Research Division, 2004, Nevada Test Site (NTS) climatological rain gauge data: National Oceanic and Atmospheric Administration, last accessed May 2004 at URL < http:// www.sord.nv.doe.gov/home_climate_rain.htm>.

Blout, D.O., Hammermeister, D.P., Zukosky, K.A., and Donnelson, K.D., 1995, Site characterization data from the Area 5 science holes, Nevada Test Site, Nye County, Nevada: U.S. Department of Energy Report DOE/ NV/11432-170, 153 p.

Brassington, Rick, 1998, Field hydrology: New York, John Wiley \& Sons, Inc., 248 p.

Bright, D.J., Watkins, S.A., and Lisle, B.A., 2001, Analysis of water levels in the Frenchman Flat area, Nevada Test Site: U.S. Geological Survey Water-Resources Investigations Report 00-4272, 43 p.

Buddemeier, R.W., and Isherwood, Dana, 1985, Radionuclide Migration Project 1984 progress report: Lawrence Livermore National Laboratory UCRL-53628, 71 p.

Clebsch, Alfred, Jr., 1961, Tritium-age of water at the Nevada Test Site, Nye County, Nevada, in Short papers in the geologic and hydrologic sciences, Geological Survey Research, 1961: U.S. Geological Survey Professional Paper 424-C, p. 122-125.

Cole, J.C., and Cashman, P.H., 1999, Structural relationships of pre-Tertiary rocks in the Nevada Test Site region, southern Nevada: U.S. Geological Survey Professional Paper 1607,39 p.

Davis, S.N., and DeWiest, R.J.M., 1966, Hydrogeology: New York, John Wiley \& Sons, Inc., 463 p.
Dettinger, M.D., and Schaefer, D.H., 1995, Decade-scale hydroclimatic forcing of ground-water levels in the central Great Basin, eastern Nevada: Summer Symposium, American Water Resources Association, Honolulu, June 1995, p. 195-204.

Dinwiddie, G.A., and Weir, J.E., Jr., 1979, Summary of hydraulic tests and hydrologic data for holes UE16d and UE16f, Syncline Ridge area, Nevada Test Site: U.S. Geological Survey Technical Letter 1543-3, 25 p.

Doty, G.C., and Rush, F.E., 1985, Inflow to a crack in playa deposits of Yucca Lake, Nevada Test Site, Nye County, Nevada: U.S. Geological Survey Water-Resources Investigations Report 84-4296, 24 p.

Doty, G.C., and Thordarson, William, 1983, Water table in rocks of Cenozoic and Paleozoic age, 1980, Yucca Flat, Nevada Test Site, Nevada: U.S. Geological Survey WaterResources Investigations Report 83-4067, 1 plate.

Dudley, W.W., Jr., and Larson, J.D., 1976, Effect of irrigation pumping on desert pupfish habitats in Ash Meadows, Nye County, Nevada: U.S. Geological Survey Professional Paper 927, 52 p.

Fenelon, J.M., 2000, Quality assurance and analysis of water levels in wells on Pahute Mesa and vicinity, Nevada Test Site, Nye County, Nevada: U.S. Geological Survey WaterResources Investigations Report 00-4014, 68 p.

Fenelon, J.M., and Moreo, M.T., 2002, Trend analysis of ground-water levels and spring discharge in the Yucca Mountain region, Nevada and California, 1960-2003: U.S. Geological Survey Water-Resources Investigations Report 02-4178, 97 p.

Flint, A.L., Flint, L.E., Kwicklis, E.M., Fabryka-Martin, J.T., Bodvarsson, G.S., 2002, Estimating recharge at Yucca Mountain, Nevada, USA - comparison of methods: Hydrogeology Journal, v. 10, p. 180-204.

Garber, M.S., 1963, Large rise and following decline of waterlevel in well 7, Area 3, Nevada Test Site - an effect from the Aardvark underground nuclear explosion: U.S. Geological Survey Technical Letter Yucca-48, 9 p.

Garber, M.S., and Koopman, F.C., 1968, Methods of measuring water levels in deep wells: U.S. Geological Survey Techniques of Water-Resources Investigations, chap. A1, book 8, 23 p.

Guerin, Marianne, 2001, Tritium and ${ }^{36} \mathrm{Cl}$ as constraints on fast fracture flow and percolation flux in the unsaturated zone at Yucca Mountain: Journal of Contaminant Hydrology, v. 51, p. 257-288. 
Hale, G.S., Trudeau, D.A., and Savard, C.S., 1995, Waterlevel data from wells and test holes through 1991 and potentiometric contours as of 1991 for Yucca Flat, Nevada Test Site, Nye County, Nevada: U.S. Geological Survey Water-Resources Investigations Report 95-4177, 1 plate.

Hale, W.E., Winograd, I.J., and Garber, M.S., 1963, Preliminary appraisal of close-in aquifer response to the Bilby event, Yucca Flat, Nevada: U.S. Geological Survey Technical Letter NTS-63, 32 p.

Harrill, J.R., Gates, J.S., and Thomas, J.M., 1988, Major ground-water flow systems in the Great Basin region of Nevada, Utah, and adjacent states: U.S. Geological Survey Hydrologic Investigations Atlas HA-694-C, 2 sheets.

Harrison, D.H., 1971, New computer programs for the calculation of earth tides: Boulder, University of Colorado, Cooperative Institute for Research in Environmental Sciences.

Hawkins, W.L., Cavazos, A.P., and Thompson, P.H., 1987, Geologic and hydrologic investigations at the Aleman (U3kz) site, and other sites in Yucca Flat, the Nevada Test Site, in Olsen, C.W., Donahue, M.L., and Wanden, S.W., eds: Fourth Symposium on Containment of Underground Nuclear Explosions, Colorado Springs, Colo., Sandia National Laboratory CONF-870961, v. 2, p. 387-398.

Hawkins, W.L., Trudeau, D.A., and Mihevc, T.M., 1990, Hydrologic testing in exploratory drill hole UE4t, Yucca Flat, the Nevada Test Site, in Olsen, CW., and Carter, J.A., eds., Fifth Symposium on the Containment of Underground Nuclear Explosions: Santa Barbara, Calif., Lawrence Livermore National Laboratory, Proceedings, CONF-8909163, v. 2, p. 141-159.

Helsel, D.R., and Hirsch, R.M., 1992, Statistical methods in water resources: New York, Elsevier Science Publishing, $522 \mathrm{p}$.

Hokett, S.L., Gillespie, D.R., Wilson, G.V., and French, R.H., 2000, Evaluation of recharge potential at subsidence crater U10i, northern Yucca Flat, Nevada Test Site: Desert Research Institute Publication No. 45174, 40 p.

Hoover, D.L., and Trudeau, D.A., 1987, High fluid levels in drill holes, Yucca Flat, Nevada Test Site, in Olsen, C.W., Donahue, M.L., and Wanden, S.W., eds: Fourth Symposium on Containment of Underground Nuclear Explosions, Colorado Springs, Colo., Sandia National Laboratory CONF-870961, v. 2, p. 363-369.

Insightful Corporation, 2001, S-PLUS 6 for Windows, guide to statistics, volume 1: Insightful Corporation, Seattle, Wash., 712 p.
Laczniak, R.J., Cole, J.C., Sawyer, D.A., and Trudeau, D.A., 1996, Summary of hydrogeologic controls on ground-water flow at the Nevada Test Site, Nye County, Nevada: U.S. Geological Survey Water-Resources Investigations Report 96-4109, 59 p.

Laczniak, R.J., Galloway, D.L., and Sneed, Michelle, 2003, InSAR detection of post-seismic and coseismic groundsurface deformation associated with underground weapons testing, Yucca Flat, Nevada Test Site, in Prince, K.R., and Galloway, D.L., U.S. Geological Survey Subsidence Interest Group Conference, proceedings of the technical meeting, Galveston, Texas, November 27-29, 2001: U.S. Geological Survey Open-File Report 03-308, p. 121-128.

Lehman, L.L., and Brown, T.P., 1996, Summary of State of Nevada-funded studies of the saturated zone at Yucca Mountain, Nevada performed by L. Lehman: L. Lehman \& Associates, Inc., Burnsville, Minn., 44 p.

Locke, G.L., and La Camera, R.J., 2003, Selected groundwater data for Yucca Mountain region, southern Nevada and eastern California, January 2000-December 2002: U.S. Geological Survey Open-File Report 03-387, 133 p.

McCutcheon, S.C., Martin, J.L., and Barnwell, Jr., T.O., 1993, Water quality, in Maidment, D.R., ed., Handbook of Hydrology: New York, McGraw-Hill, Inc., p. 11.2-11.6.

Moore, J.E., Doyle, A.C., Walker, G.E., and Young, R.A., 1963, Ground water test well 2, Nevada Test Site, Nye County, Nevada: U.S. Geological Survey Trace Element Investigations 836, $73 \mathrm{p}$.

Moreo, M.T., Halford, K.J., La Camera, R.J., and Laczniak, R.J., 2003, Estimated ground-water withdrawals from the Death Valley regional flow system, Nevada and California, 1913-98: U.S. Geological Survey Water-Resources Investigations Report 2003-4245, 28 p.

O’Brien, G.M., 1992, Earthquake-induced water-level fluctuations at Yucca Mountain, Nevada, April, 1992: U.S. Geological Survey Open-File Report 92-137, 10 p.

Phelps, G.A., and McKee, E.H., 1999, High-angle faults in the basement of Yucca Flat, Nevada Test Site, Nevada, based on analysis of a constrained gravity inversion surface: U.S. Geological Survey Open-File Report 99-383, 10 p.

Price, C.E., 1960, Granite exploration hole, Area 15, Nevada Test Site, Nye County, Nevada-interim report, part B, hydrologic data: U.S. Geological Survey Open-File Report 60-115, 17 p.

Rojstaczer, Stuart, 1988, Determination of fluid flow properties from the response of water levels in wells to atmospheric loading: Water Resources Research, v. 24, no. 11, p. 1927-1938. 
Russell, C.E., Gillespie, David, Cole, J.C., Drellack, S.L., Prothro, L.B., Thompson, P.H., McCall, R.L., Pawloski, G.A., and Carlson, Richard, 1996, ER-12-1 completion report: Desert Research Institute Publication No. 45120, $158 \mathrm{p}$.

Thompson, J.L., ed., 1998, Laboratory and field studies related to radionuclide migration at the Nevada Test Site, October 1, 1996 - September 30, 1997: Los Alamos National Laboratory LA-13419-PR Progress Report, 31 p.

Thordarson, William, Garber, M.S., and Walker, G.E., 1962, Ground water test well D, Nevada Test Site, Nye County, Nevada: U.S. Geological Survey Open-File Report 62-134, $58 \mathrm{p}$.

Thordarson, William, Young, R.A., and Winograd, I.J., 1967, Records of wells and test holes in the Nevada Test Site and vicinity (through December 1966): U.S. Geological Survey Open-File Report 67-218, 26 p.

Thordarson, William, and Winograd, I.J., 1962, Drill-stem tests of strata penetrated in drill hole UE4a, Nevada Test Site: U.S. Geological Survey Technical Letter Yucca 2, Supplement 6, 19 p.

Tyler, S.W., Chapman, J.B., Conrad, S.H., Hammermeister, D.P., Blout, D.O., Miller, J.J., Sully, M.J., and Ginanni, J.M., 1996, Soil-water flux in the southern Great Basin, United States-Temporal and spatial variations over the last 120,000 years: Water Resources Research, v. 32, no. 6, p. 1481-1499.

U.S. Congress, Office of Technology Assessment, 1989, The containment of underground nuclear explosions: Office of Technology Assessment OTA-ISC-414, 79 p.
U.S. Department of Energy, 2000, United States nuclear tests, July 1945 through September 1992: U.S. Department of Energy, Nevada Operations Office, DOE/NV-209 (rev. 15), $162 \mathrm{p}$.

Vincent, Paul, Larsen, Shawn, Galloway, D.L., Laczniak, R.J., Walter, W.R., Foxall, William, and Zucca, J.J., 2003, New signatures of underground nuclear tests revealed by satellite radar interferometry: Geophysical Research Letters, v. 30, no. 22, 2141, paper no. 10.1029/2003GL018179, p. 1-11-5.

Weeks, E.P., 1979, Barometric fluctuations in wells tapping deep unconfined aquifers: Water Resources Research, v. 15, no. 5, p. 1167-1176.

Weir, J.E., Jr., and Hodson, J.N., 1979, Geohydrology of hole UE-17a, Syncline Ridge area, Nevada Test Site: U.S. Geological Survey Technical Letter USGS-1543-4, 18 p.

Winograd, I.J., 1970, Noninstrumental factors affecting measurement of static water levels in deeply buried aquifers and aquitards, Nevada Test Site: Ground Water, v. 8, no. 2, p. 19-28.

Winograd, I.J., Riggs, A.C., and Coplen, T.B., 1998, The relative contributions of summer and cool-season precipitation to groundwater recharge, Spring Mountains, Nevada, USA: Hydrogeology Journal, v. 6, p. 77-93.

Winograd, I.J., and Thordarson, William, 1975, Hydrogeologic and hydrochemical framework, south-central Great Basin, Nevada-California, with special reference to the Nevada Test Site: U.S. Geological Survey Professional Paper 712-C, $126 \mathrm{p}$. 


\section{Appendix 1: Water-level database for Yucca Flat, 1951-2003}

The database distributed with this report is in Microsoft ${ }^{\circledR}$ Access 2000 format. It contains 17 tables with hydrologic information for 216 wells in Yucca Flat. The tables include information on well sites, well construction, borehole lithology, aquifers, and water levels. Descriptions of the types of information in the database tables are listed in table 10. These descriptions also are stored in the database. A general description of each table can be read in the Access project window by opening the database, selecting "view," and then selecting "details." Descriptions of each table column can be made to appear at the bottom of the database window screen by opening a table and moving the cursor to the column of interest.

A Microsoft ${ }^{\circledR}$ Excel workbook also is distributed with this report as an interface to the water-level database. Most of the water-level information from the database is provided in the spreadsheet. Different hydrographs from Yucca Flat can be selected using Excel's built-in AutoFilter. 
[Fixed variables: A set of variables that applies to a column in the database. Abbreviations: NA, not applicable; HA, hydrographic area]

\begin{tabular}{|c|c|c|c|}
\hline \multicolumn{4}{|c|}{ Site Information } \\
\hline Access table name & Table column name & Description & Fixed variables \\
\hline YF_sitefile & USGS_local_nm & USGS local well name & NA \\
\hline YF_sitefile & USGS_site_id & USGS unique well identification number & NA \\
\hline YF_sitefile & station_nm & $\begin{array}{l}\text { USGS official NWIS site name (format is: hydrographic } \\
\text { area, township, range, section, sequence number, } \\
\text { USGS local name) }\end{array}$ & NA \\
\hline YF_sitefile & redbk_nm & Official DOE hole name at well site & NA \\
\hline YF_sitefile & lat_va & $\begin{array}{l}\text { Latitude, in degrees, minutes, and decimal seconds; } \\
\text { datum is North American Datum of } 1927\end{array}$ & NA \\
\hline YF_sitefile & long_va & $\begin{array}{l}\text { Longitude, in degrees, minutes, and decimal seconds; } \\
\text { datum is North American Datum of } 1927\end{array}$ & NA \\
\hline YF_sitefile & dec_lat_va & $\begin{array}{l}\text { Latitude, in decimal degrees; datum is North American } \\
\text { Datum of } 1983\end{array}$ & NA \\
\hline YF_sitefile & dec_long_va & $\begin{array}{l}\text { Longitude, in decimal degrees; datum is North American } \\
\text { Datum of } 1983\end{array}$ & NA \\
\hline YF_sitefile & easting & $\begin{array}{l}\text { Universal Transverse Mercator Projection easting, in } \\
\text { meters, Zone 11, North American Datum of } 1927\end{array}$ & NA \\
\hline YF_sitefile & northing & $\begin{array}{l}\text { Universal Transverse Mercator Projection northing, in } \\
\text { meters, Zone 11, North American Datum of } 1927\end{array}$ & NA \\
\hline YF_sitefile & coord_meth & Method used to measure horizontal coordinates & Unknown; Survey \\
\hline YF_sitefile & coord_acy & $\begin{array}{l}\text { Accuracy of horizontal latitude and longitude } \\
\text { coordinates }\end{array}$ & Hndrth second; Second \\
\hline YF_sitefile & state & State where well is located & NEVADA \\
\hline YF_sitefile & county & County where well is located & NYE \\
\hline YF_sitefile & map_nm & $\begin{array}{l}1: 24,000 \text { USGS topographic quadrangle on which well is } \\
\text { located }\end{array}$ & NA \\
\hline YF_sitefile & alt_va & $\begin{array}{l}\text { Altitude of land surface at well, in feet; datum is National } \\
\text { Geodetic Vertical Datum of } 1929\end{array}$ & NA \\
\hline YF_sitefile & alt_meth & Method used to measure land-surface altitude & DGPS (differential GPS); Level; Reported; Map \\
\hline YF_sitefile & alt_acy_va & Accuracy of land-surface altitude, in feet & NA \\
\hline YF_sitefile & hyd_area_nu & Hydrographic area where well is located & $\begin{array}{l}\text { HA159 (Yucca Flat); HA160 (Frenchman Flat); } \\
\text { HA158A (Groom Lake Valley) }\end{array}$ \\
\hline YF_sitefile & huc & Hydrologic Unit Code & NA \\
\hline YF_sitefile & NTS area number & NTS area number & NA \\
\hline
\end{tabular}


Table 10. Description of Microsoft® Access database for Yucca Flat water-level measurements—Continued

\begin{tabular}{|c|c|c|c|}
\hline \multicolumn{4}{|c|}{ Site Information-Continued } \\
\hline Access table name & Table column name & Description & Fixed variables \\
\hline YF_sitefile & site_rmks_tx & General remarks about the well site & NA \\
\hline YF_sitefile & site_use_1 & Primary use of well site & Destroyed; Test; Withdrawal \\
\hline YF_sitefile & site_use_2 & Secondary use of well site & Test; Observation; Withdrawal \\
\hline YF_sitefile & water_use_1 & Use of water at well site & Unused; Institutional \\
\hline YF_gw_Is_alt & Is_alt_seq_nu & Sequence number of measured land-surface altitude & NA \\
\hline YF_gw_Is_alt & Is_alt & $\begin{array}{l}\text { Altitude of land surface at well, in feet; datum is National } \\
\text { Geodetic Vertical Datum of } 1929\end{array}$ & NA \\
\hline YF_gw_ls_alt & Is_alt_src & Source of land-surface altitude & NA \\
\hline YF_gw_ls_alt & Is_alt_acc & Accuracy of land-surface altitude measurement, in feet & NA \\
\hline YF_gw_Is_alt & Is_alt_meth & Method used to determine land-surface altitude & DGPS (differential GPS); L (level); U (unknown) \\
\hline YF_gw_ls_alt & Is_alt_dt & $\begin{array}{l}\text { Date land-surface altitude was determined, in yymmdd } \\
\text { format }\end{array}$ & NA \\
\hline YF_gw_ls_alt & Is_alt_dtm & Date land-surface altitude was determined & NA \\
\hline YF_gw_ls_alt & Is_alt_dtm_acc & $\begin{array}{l}\text { Accuracy of date when land-surface altitude was } \\
\text { determined }\end{array}$ & Year; Day \\
\hline YF_gw_ls_alt & Is_desc & Description of land-surface where altitude was measured & INA \\
\hline YF_gw_mpnt & mpnt_seq_nu & Sequence number of well measuring point & NA \\
\hline YF_gw_mpnt & mpnt_begin_dtm & Date measuring point was established & NA \\
\hline YF_gw_mpnt & mpnt_end_dtm & Date measuring point was discontinued & NA \\
\hline YF_gw_mpnt & mpnt_ht_va & Height of measuring point above land surface, in feet & NA \\
\hline YF_gw_mpnt & mpnt_alt_va & $\begin{array}{l}\text { Altitude of measuring point, in feet; datum is National } \\
\text { Geodetic Vertical Datum of } 1929\end{array}$ & NA \\
\hline YF_gw_mpnt & mpnt_alt_meth & Method used to measure measuring-point altitude & DGPS (differential GPS); L (level) \\
\hline YF_gw_mpnt & mpnt_alt_acy_va & Accuracy of measuring-point altitude, in feet & NA \\
\hline YF_gw_mpnt & mpnt_ds & Description of measuring point & NA \\
\hline YF_gw_rmks & gw_rmks_seq_nu & Sequence number of remark & NA \\
\hline YF_gw_rmks & gw_rmks_dtm & Date corresponding to remark & NA \\
\hline YF_gw_rmks & gw_rmks_dtm_acc & $\begin{array}{l}\text { Accuracy of date entry ("Year" means remark date only } \\
\text { applies to the year) }\end{array}$ & Day; Month; Year \\
\hline
\end{tabular}




\begin{tabular}{|c|c|c|c|}
\hline \multicolumn{4}{|c|}{ Well-Construction Records } \\
\hline Access table name & Table column name & Description & Fixed variables \\
\hline YF_gw_cons & cons_begin_dtm & Date well construction began & NA \\
\hline YF_gw_cons & cons_end_dtm & Date well construction was completed & NA \\
\hline YF_gw_cons & hole_depth_va & $\begin{array}{l}\text { Depth of hole, in feet, that was drilled prior to } \\
\text { establishing well site }\end{array}$ & NA \\
\hline YF_gw_cons & well_depth_va & $\begin{array}{l}\text { Depth of well, in feet; generally considered the depth that } \\
\text { is accessible. }\end{array}$ & tNA \\
\hline YF_gw_cons & depth_src & Source of information for hole-depth and well-depth data & Driller; Other reported; Geologist \\
\hline YF_gw_cons & cons_contractor_nm & Name of drilling contractor & NA \\
\hline YF_gw_cons & cons_src & Source of construction data & Other reported; Geologist; Driller \\
\hline YF_gw_cons & cons_meth & Drilling method & Air rotary; Hydraulic rotary; Cable tool; Reverse rotary \\
\hline YF_gw_cons & finish & Type of finish around open interval & $\begin{array}{l}\text { Perf or Slotted; Gravel pck, perf; Gravel pck, scrn; } \\
\text { Open hole }\end{array}$ \\
\hline YF_gw_cons & seal & Type of well seal above open interval & Cement grout \\
\hline YF_gw_cons & seal_depth_va & Depth to bottom of seal, in feet below land surface & NA \\
\hline YF_gw_hole & hole_seq_nu & Sequence number of hole interval & NA \\
\hline YF_gw_hole & hole_top_va & Top of hole interval, in feet below land surface & NA \\
\hline YF_gw_hole & hole_bottom_va & Bottom of hole interval, in feet below land surface & NA \\
\hline YF_gw_hole & hole_dia_va & Diameter of hole interval, in inches & NA \\
\hline YF_gw_csng & csng_seq_nu & Sequence number of casing interval & NA \\
\hline YF_gw_csng & csng_top_va & Top of casing interval, in feet below land surface & NA \\
\hline YF_gw_csng & csng_bottom_va & Bottom of casing interval, in feet below land surface & NA \\
\hline YF_gw_csng & csng_dia_va & Diameter of casing interval, in inches & NA \\
\hline YF_gw_csng & csng_material & Casing material & $\begin{array}{l}\text { Steel carbon; Stainless steel; Steel; Galvanized iron; } \\
\text { Fiberglass }\end{array}$ \\
\hline YF_gw_csng & csng_thick_va & Thickness of casing, in inches & NA \\
\hline YF_gw_open & open_seq_nu & Sequence number of open interval & NA \\
\hline YF_gw_open & open_top_va & Top of open interval, in feet below land surface & NA \\
\hline YF_gw_open & open_bottom_va & Bottom of open interval, in feet below land surface & NA \\
\hline YF_gw_open & open_dia_va & Diameter of open interval, in inches & NA \\
\hline YF_gw_open & open_material & Material comprising open interval & Steel; Other; Stainless steel; Steel carbon \\
\hline YF_gw_open & open & Type of opening & Perforated; Open hole; Screen; Other \\
\hline
\end{tabular}


Table 10. Description of Microsoft ${ }^{\circledR}$ Access database for Yucca Flat water-level measurements—Continued

\begin{tabular}{|c|c|c|c|}
\hline \multicolumn{4}{|c|}{ Borehole lithology and aquifer data } \\
\hline Access table name & Table column name & Description & Fixed variables \\
\hline YF_gw_lith & lith_seq_nu & Sequence number of lithologic interval & NA \\
\hline YF_gw_lith & lith_top_va & Top of lithologic interval, in feet below land surface & NA \\
\hline YF_gw_lith & lith_bottom_va & Bottom of lithologic interval, in feet below land surface & NA \\
\hline YF_gw_lith & lith_descr_tx & Lithologic description of lithologic interval & NA \\
\hline YF_gw_lith & lith_rmk & Other remarks pertinent to the lithology of the interval & NA \\
\hline YF_lith_tops & vf_top & Depth to top of valley fill, in feet below land surface & NA \\
\hline YF_lith_tops & tert_volc_top & $\begin{array}{l}\text { Depth to top of Tertiary volcanics, in feet below land } \\
\text { surface }\end{array}$ & NA \\
\hline YF_lith_tops & pre_T_carbs_top & $\begin{array}{l}\text { Depth to top of pre-Tertiary carbonate rocks, in feet } \\
\text { below land surface }\end{array}$ & NA \\
\hline YF_lith_tops & pre_T_clastic_top & $\begin{array}{l}\text { Depth to top of pre-Tertiary clastic rocks, in feet below } \\
\text { land surface }\end{array}$ & NA \\
\hline YF_lith_tops & lith_top_src & Source of information for depth to top of lithologic unit & $\begin{array}{l}\text { Reported (data reported on lithologic log or other } \\
\text { documented source); Estimated (data estimated from } \\
\text { nearby logs or some other source) }\end{array}$ \\
\hline YF_gw_aqfr & aqfr_cd_1 & Code for primary aquifer contributing water to well & $\begin{array}{l}\text { C (pre-Tertiary carbonate rocks); F (valley fill); S (pre- } \\
\text { Tertiary clastic rocks); V (volcanic rocks); X (igneous or } \\
\text { metamorphic rocks) }\end{array}$ \\
\hline YF_gw_aqfr & aqfr_cd_2 & Code for secondary aquifer contributing water to well & $\begin{array}{l}\text { C (pre-Tertiary carbonate rocks); F (valley fill); P } \\
\text { (paleocolluvium); S (pre-Tertiary clastic rocks); V } \\
\text { (volcanic rocks); X (igneous or metamorphic rocks) }\end{array}$ \\
\hline YF_gw_aqfr & aqfr_cd_3 & Code for tertiary aquifer contributing water to well & $\begin{array}{l}\text { C (pre-Tertiary carbonate rocks); S (pre-Tertiary clastic } \\
\text { rocks); V (volcanic rocks); X (igneous or metamorphic } \\
\text { rocks) }\end{array}$ \\
\hline YF_gw_aqfr & aqfr & Primary aquifer contributing water to well & NA \\
\hline YF_gw_aqfr & aqfr_era & Geologic era of primary aquifer & NA \\
\hline YF_gw_aqfr & aqfr_system & Geologic system of primary aquifer & NA \\
\hline YF_gw_aqfr & aqfr_series & Geologic series of primary aquifer & NA \\
\hline
\end{tabular}




\begin{tabular}{|c|c|c|c|}
\hline \multicolumn{4}{|c|}{ Water-level data } \\
\hline Access table name & Table column name & Description & Fixed variables \\
\hline YF_gw_lev & lev_dtm & Date and time water level was measured & NA \\
\hline YF_gw_lev & lev_dtm_acc & Accuracy to which the water-level date was entered & Minute; Day; Month; Year \\
\hline YF_gw_lev & lev_ddy & Date, as a decimal year, that water level was measured & NA \\
\hline YF_gw_lev & lev_va & Depth to water, in feet below land surface & NA \\
\hline YF_gw_lev & sl_lev_va & $\begin{array}{l}\text { Water-level altitude, in feet above sea level; datum is } \\
\text { National Geodetic Vertical Datum of } 1929\end{array}$ & NA \\
\hline YF_gw_lev & lev_src & Source of water-level measurement & USGS; Other reported; Geologist; Driller \\
\hline YF_gw_lev & lev_status & Status of water-level measurement & $\begin{array}{l}\text { Dry; Nearby pumping; Obstruction; Other; Pumping; } \\
\text { Recently pumped }\end{array}$ \\
\hline YF_gw_lev & lev_meth & Method of water-level measurement & $\begin{array}{l}\text { Airline; Calib. elec. Tape; Electric tape (uncalibrated); } \\
\text { Geophysical log; Other; Pressure gage; Reported; } \\
\text { Steel tape; Transducer; Unknown }\end{array}$ \\
\hline YF_gw_lev & lev_acy & Accuracy of water-level measurement, in feet & $\begin{array}{l}\text { Nearest } 1 / 10 \text { foot; Nearest } 1 / 100 \text { foot; Nearest foot; Not } \\
\text { nearest foot }\end{array}$ \\
\hline YF_gw_lev & lev_party_tx & Organization making measurement & $\begin{array}{l}\text { EG\&G (NTS contractor); F\&S (Fenix \& Scisson--NTS } \\
\text { contractor); NTS (USGS measurements collected } \\
\text { after about } 1996 \text { for Nevada Test Site Program); } \\
\text { NV013 (Desert Research Institute); Shaw (Shaw } \\
\text { Environmental, Inc.); WTP (USGS measurements } \\
\text { collected prior to about } 1996 \text { for NTS Weapons Testing } \\
\text { Program) }\end{array}$ \\
\hline YF_wl_rmks & wl_rmks_seq_nu & Sequence number of remark & NA \\
\hline YF_wl_rmks & wl_rmks_dtm & Date of water level corresponding to remark & NA \\
\hline YF_wl_rmks & wl_rmks_dtm_acc & $\begin{array}{l}\text { Accuracy of date entry ("Year" means remark date only } \\
\text { applies to the year) }\end{array}$ & Day; Month; Year \\
\hline YF_wl_rmks & wl_rmks_tx & Remark relating to specific water level & NA \\
\hline
\end{tabular}


Table 10. Description of Microsoft $₫$ Access database for Yucca Flat water-level measurements-Continued

\begin{tabular}{|c|c|c|c|}
\hline \multicolumn{4}{|c|}{ Water-level data--Continued } \\
\hline Access table name & Table column name & Description & Fixed variables \\
\hline YF_wl_attrib_gen & wl_attrib_gen & $\begin{array}{l}\text { Attribute assigned to water level to describe the general } \\
\text { hydrologic condition at the time of measurement }\end{array}$ & $\begin{array}{l}\text { Insufficient data; Localized conditions; None; } \\
\text { Nonstatic level; Steady state-LOCAL; Steady state- } \\
\text { REGIONAL; Suspect; Transient—REGIONAL }\end{array}$ \\
\hline YF_wl_attrib_det & wl_attrib_det_seq_nu & Sequence number of detailed hydrologic condition & NA \\
\hline YF_wl_attrib_det & wl_attrib_det & $\begin{array}{l}\text { Attribute assigned to water level to describe the detailed } \\
\text { hydrologic condition at the time of measurement }\end{array}$ & $\begin{array}{l}\text { Abrupt change; Anomalous - high; Anomalous - low; } \\
\text { Borehole deviation; Consistent; Declining trend; Dry; } \\
\text { Elevated; Equilibration; Erratic/Unstable; Injection/ } \\
\text { Recovery; Limited data; Maximum estimate; Minimum } \\
\text { estimate; Nearby drilling effect; Nuclear-test effect; } \\
\text { Obstruction; Packer test; Pumping area; Pumping/ } \\
\text { Recovery; Rising trend; Suspected perched water; } \\
\text { Testing area; Undeveloped; Well-construction effect }\end{array}$ \\
\hline YF_hyd_narrative & hyd_narrative & $\begin{array}{l}\text { Narrative discussing well site, hydrograph, and specific } \\
\text { water levels. }\end{array}$ & NA \\
\hline
\end{tabular}




\section{Appendix 2. Characteristics of underground nuclear detonations in Yucca Flat and vicinity, Nevada Test Site, 1951-1992}


Appendix 2. Characteristics of underground nuclear detonations in Yucca Flat and vicinity, Nevada Test Site, 1951-1992

Land-surface altitude: Altitude in feet above sea level.

Shot distance above water table: Distance in feet. Negative values indicate distance below water table.

[NTS, Nevada Test Site; kt, kiloton; NAD83, North American Datum of 1983; NA, not available. Source of data: U.S. Department of Energy (2000)]

\begin{tabular}{|c|c|c|c|c|c|c|c|c|c|}
\hline NTS hole name & $\begin{array}{c}\text { NTS } \\
\text { area } \\
\text { no. }\end{array}$ & Test name & $\begin{array}{l}\text { Test } \\
\text { date }\end{array}$ & Test yield & $\begin{array}{l}\text { Land- } \\
\text { surface } \\
\text { altitude }\end{array}$ & $\begin{array}{l}\text { Burial } \\
\text { depth } \\
\text { (feet) }\end{array}$ & $\begin{array}{c}\text { Shot } \\
\text { distance } \\
\text { above } \\
\text { water } \\
\text { table }\end{array}$ & $\begin{array}{l}\text { Decimal } \\
\text { Latitude } \\
\text { (NAD83) }\end{array}$ & $\begin{array}{l}\text { Decimal } \\
\text { Longitude } \\
\text { (NAD83) }\end{array}$ \\
\hline Ess Crater & 10 & Ess & $3 / 23 / 1955$ & $1 \mathrm{kt}$ & 4,259 & NA & 1,839 & 37.168286 & 116.044759 \\
\hline U-1a.01 & 01 & Ledoux & 9/27/1990 & Less than $20 \mathrm{kt}$ & 3,996 & 955 & 617 & 37.007097 & 116.059089 \\
\hline U-1c Mining & 01 & Yerba & $12 / 14 / 1971$ & Less than $20 \mathrm{kt}$ & 4,031 & 1,089 & 520 & 37.023211 & 116.059500 \\
\hline U-1d & 01 & Sundown-A & $9 / 20 / 1990$ & Less than $20 \mathrm{kt}$ & 4,047 & 887 & 736 & 37.038169 & 116.057667 \\
\hline U-1d & 01 & Sundown-B & 9/20/1990 & Less than $20 \mathrm{kt}$ & 4,047 & 887 & 783 & 37.038169 & 116.057667 \\
\hline U-2a & 02 & Alpaca & $2 / 12 / 1965$ & $0.330 \mathrm{kt}$ & 4,402 & 738 & 1,242 & 37.164483 & 116.077416 \\
\hline U-2aa & 02 & Club & $1 / 30 / 1964$ & Less than $20 \mathrm{kt}$ & 4,296 & 593 & 1,243 & 37.136163 & 116.071527 \\
\hline U-2ab & 02 & Tee & $5 / 7 / 1965$ & $7 \mathrm{kt}$ & 4,297 & 605 & 1,227 & 37.140319 & 116.067521 \\
\hline U-2ad & 02 & Cashmere & 2/4/1965 & Less than $20 \mathrm{kt}$ & 4,256 & 765 & 1,042 & 37.130697 & 116.062465 \\
\hline U-2af & 02 & Kennebec & $6 / 25 / 1963$ & Low & 4,275 & 742 & 1,075 & 37.131352 & 116.068935 \\
\hline U-2ag & 02 & Mullet & 10/17/1963 & Low & 4,270 & 198 & 1,613 & 37.130761 & 116.067832 \\
\hline U-2ah & 02 & Pongee & $7 / 22 / 1965$ & Less than $20 \mathrm{kt}$ & 4,270 & 442 & 1,375 & 37.131747 & 116.067724 \\
\hline U-2ai & 02 & Drill (Source-Lower) & $12 / 5 / 1964$ & $3.4 \mathrm{kt}$ & 4,286 & 718 & 1,110 & 37.134236 & 116.070624 \\
\hline U-2ai & 02 & Drill (Target-Upper) & $12 / 5 / 1964$ & Less than $20 \mathrm{kt}$ & 4,286 & 618 & 1,211 & 37.134236 & 116.070624 \\
\hline U-2ak & 02 & Centaur & $8 / 27 / 1965$ & Less than $20 \mathrm{kt}$ & 4,299 & 570 & 1,275 & 37.137258 & 116.070943 \\
\hline U-2aL & 02 & Emerson & $12 / 16 / 1965$ & Less than $20 \mathrm{kt}$ & 4,289 & 855 & 996 & 37.140791 & 116.064049 \\
\hline U-2am & 02 & Commodore & $5 / 20 / 1967$ & $250 \mathrm{kt}$ & 4,258 & 2,445 & -644 & 37.130361 & 116.064818 \\
\hline U-2an & 02 & Tapestry & $5 / 12 / 1966$ & Less than $20 \mathrm{kt}$ & 4,291 & 816 & 1,013 & 37.134238 & 116.071988 \\
\hline U-2ao & 09 & Flotost & 8/16/1977 & Less than $20 \mathrm{kt}$ & 4,301 & 902 & 963 & 37.146672 & 116.063982 \\
\hline U-2ap & 02 & Effendi & $4 / 27 / 1967$ & Less than $20 \mathrm{kt}$ & 4,284 & 725 & 1,112 & 37.138736 & 116.064074 \\
\hline U-2ar & 02 & Asiago & 12/21/1976 & Less than $20 \mathrm{kt}$ & 4,239 & 1,085 & 706 & 37.123863 & 116.068326 \\
\hline U-2as & 02 & Clarksmobile & $5 / 17 / 1968$ & 20 to $200 \mathrm{kt}$ & 4,218 & 1,550 & 139 & 37.120003 & 116.059701 \\
\hline U-2at & 02 & Knox & $2 / 21 / 1968$ & 20 to $200 \mathrm{kt}$ & 4,199 & 2,115 & -464 & 37.116508 & 116.054568 \\
\hline U-2au & 02 & Ildrim & $7 / 16 / 1969$ & 20 to $200 \mathrm{kt}$ & 4,209 & 1,346 & 340 & 37.119383 & 116.055987 \\
\hline U-2av & 02 & Calabash & 10/29/1969 & $110 \mathrm{kt}$ & 4,298 & 2,050 & -182 & 37.143269 & 116.064716 \\
\hline U-2aw & 02 & Stanyan & 9/26/1974 & 20 to $200 \mathrm{kt}$ & 4,271 & 1,880 & -63 & 37.132580 & 116.069260 \\
\hline U-2ax & 02 & Portmanteau & 8/30/1974 & 20 to $200 \mathrm{kt}$ & 4,397 & 2,150 & -182 & 37.152433 & 116.084203 \\
\hline U-2ay \#1 Zero Station & 02 & Yannigan-Red & 2/26/1970 & 20 to $200 \mathrm{kt}$ & 4,214 & 1,286 & 380 & 37.116316 & 116.062312 \\
\hline U-2ay \#2 Zero Station & 02 & Yannigan-White & 2/26/1970 & 20 to $200 \mathrm{kt}$ & 4,227 & 1,295 & 420 & 37.118002 & 116.067318 \\
\hline U-2ay \#3 Zero Station & 02 & Yannigan-Blue & 2/26/1970 & 20 to $200 \mathrm{kt}$ & 4,214 & 1,193 & 481 & 37.113755 & 116.066668 \\
\hline U-2az \#1 & 02 & Flask-Green & $5 / 26 / 1970$ & $105 \mathrm{kt}$ & 4,192 & 1,734 & -104 & 37.113319 & 116.063204 \\
\hline U-2az \#2 & 02 & Flask-Yellow & $5 / 26 / 1970$ & 90 tons & 4,220 & 1,100 & 594 & 37.118083 & 116.064435 \\
\hline U-2az \#3 & 02 & Flask-Red & $5 / 26 / 1970$ & 35 tons & 4,220 & 500 & 1,198 & 37.116147 & 116.067574 \\
\hline$U-2 b$ & 02 & St. Lawrence & 11/9/1962 & Low & 4,384 & 547 & 1,420 & 37.163766 & 116.074163 \\
\hline$U-2 b c$ & 02 & Parnassia & $11 / 30 / 1971$ & Less than $20 \mathrm{kt}$ & 4,360 & 1,085 & 856 & 37.160399 & 116.071105 \\
\hline $\mathrm{U}-2 \mathrm{bd}$ & 02 & Vulcan & $6 / 25 / 1966$ & $25 \mathrm{kt}$ & 4,354 & 1,059 & 873 & 37.155258 & 116.073030 \\
\hline U-2be & 02 & Noor & 4/10/1968 & 20 to $200 \mathrm{kt}$ & 4,385 & 1,250 & 702 & 37.154330 & 116.079724 \\
\hline$U-2 b f$ & 02 & Gourd-Amber & 4/24/1969 & Less than $20 \mathrm{kt}$ & 4,418 & 595 & 1,393 & 37.163922 & 116.080511 \\
\hline
\end{tabular}


Appendix 2. Characteristics of underground nuclear detonations in Yucca Flat and vicinity, Nevada Test Site, 1951-1992—Continued Land-surface altitude: Altitude in feet above sea level.

Shot distance above water table: Distance in feet. Negative values indicate distance below water table.

[NTS, Nevada Test Site; kt, kiloton; NAD83, North American Datum of 1983; NA, not available. Source of data: U.S. Department of Energy (2000)]

\begin{tabular}{|c|c|c|c|c|c|c|c|c|c|}
\hline NTS hole name & $\begin{array}{c}\text { NTS } \\
\text { area } \\
\text { no. }\end{array}$ & Test name & $\begin{array}{l}\text { Test } \\
\text { date }\end{array}$ & Test yield & $\begin{array}{l}\text { Land- } \\
\text { surface } \\
\text { altitude }\end{array}$ & $\begin{array}{l}\text { Burial } \\
\text { depth } \\
\text { (feet) }\end{array}$ & $\begin{array}{c}\text { Shot } \\
\text { distance } \\
\text { above } \\
\text { water } \\
\text { table }\end{array}$ & $\begin{array}{l}\text { Decimal } \\
\text { Latitude } \\
\text { (NAD83) }\end{array}$ & $\begin{array}{c}\text { Decimal } \\
\text { Longitude } \\
\text { (NAD83) }\end{array}$ \\
\hline U-2bg & 02 & Throw & $4 / 10 / 1968$ & Less than $20 \mathrm{kt}$ & 4,408 & 750 & 1,214 & 37.156633 & 116.083141 \\
\hline U-2bh & 02 & Scuttle & $11 / 13 / 1969$ & 1.7 kt & 4,394 & 540 & 1,435 & 37.164583 & 116.075702 \\
\hline U-2bj & 02 & Imp & 8/9/1968 & Less than $20 \mathrm{kt}$ & 4,399 & 600 & 1,388 & 37.161741 & 116.078058 \\
\hline$U-2 b L$ & 02 & Gourd-Brown & $4 / 24 / 1969$ & Less than $20 \mathrm{kt}$ & 4,409 & 744 & 1,225 & 37.159916 & 116.081744 \\
\hline U-2bm & 02 & Lexington & $8 / 24 / 1967$ & Less than $20 \mathrm{kt}$ & 4,386 & 743 & 1,223 & 37.162683 & 116.075033 \\
\hline$U-2 b n$ & 02 & Chatty & 3/18/1969 & Less than $20 \mathrm{kt}$ & 4,394 & 640 & 1,332 & 37.162227 & 116.076752 \\
\hline U-2bo \#1 Zero Station & 02 & Bowl-1 & $6 / 26 / 1969$ & Less than $20 \mathrm{kt}$ & 4,407 & 650 & 1,329 & 37.162436 & 116.079494 \\
\hline U-2bq \#1 Zero Station & 10 & Kyack-A & $9 / 20 / 1969$ & Less than $20 \mathrm{kt}$ & 4,342 & 610 & 1,292 & 37.158699 & 116.068599 \\
\hline U-2bq \#2 Zero Station & 10 & Kyack-B & 9/20/1969 & Less than $20 \mathrm{kt}$ & 4,331 & 630 & 1,300 & 37.157372 & 116.067041 \\
\hline$U-2 b r$ & 02 & Harebell & $6 / 24 / 1971$ & 20 to $200 \mathrm{kt}$ & 4,312 & 1,702 & 176 & 37.146647 & 116.067710 \\
\hline$U-2 b s$ & 02 & Starwort & $4 / 26 / 1973$ & $90 \mathrm{kt}$ & 4,226 & 1,850 & -127 & 37.123000 & 116.059384 \\
\hline U-2bu & 04 & Miniata & 7/8/1971 & $83 \mathrm{kt}$ & 4,179 & 1,735 & -115 & 37.110078 & 116.052289 \\
\hline$U-2 b v$ & 02 & Portulaca & 6/28/1973 & 20 to $200 \mathrm{kt}$ & 4,388 & 1,530 & 411 & 37.148377 & 116.086725 \\
\hline U-2bw & 09 & Sutter & $12 / 21 / 1976$ & Less than $20 \mathrm{kt}$ & 4,312 & 656 & 1,223 & 37.151853 & 116.064304 \\
\hline$U-2 b x$ & 10 & Hulsea & $3 / 14 / 1974$ & Less than $20 \mathrm{kt}$ & 4,319 & 640 & 1,254 & 37.155083 & 116.064966 \\
\hline U-2ce & 02 & Nash & 1/19/1967 & $39 \mathrm{kt}$ & 4,764 & 1,198 & 535 & 37.143607 & 116.136077 \\
\hline$U-2 c g$ & 02 & Heilman & 4/6/1967 & Less than $20 \mathrm{kt}$ & 4,699 & 501 & 1,242 & 37.137277 & 116.133552 \\
\hline $\mathrm{U}-2 \mathrm{ch}$ & 02 & Pod-A & $10 / 29 / 1969$ & 16.7 kt (Pod total) & 4,671 & 875 & 898 & 37.140160 & 116.131374 \\
\hline U-2ci & 02 & Pod-B & $10 / 29 / 1969$ & $16.7 \mathrm{kt}$ (Pod total) & 4,894 & 816 & 641 & 37.140399 & 116.142708 \\
\hline U-2cj & 02 & Pod-C & 10/29/1969 & 16.7 kt (Pod total) & 4,838 & 560 & 970 & 37.136282 & 116.140838 \\
\hline U-2ck & 02 & Pod-D & 10/29/1969 & 16.7 kt (Pod total) & 4,761 & 1,025 & 656 & 37.135291 & 116.136824 \\
\hline U-2cm-S & 02 & Stoddard & 9/17/1968 & 20 to $200 \mathrm{kt}$ & 4,583 & 1,535 & 178 & 37.119816 & 116.128343 \\
\hline$U-2 c n$ & 02 & Cruet & 10/29/1969 & $11 \mathrm{kt}$ & 4,589 & 865 & 851 & 37.121466 & 116.128621 \\
\hline U-2co & 02 & Kryddost & 5/6/1982 & Less than $20 \mathrm{kt}$ & 4,562 & 1,099 & 592 & 37.116793 & 116.127779 \\
\hline U-2cp & 02 & Caboc & 12/16/1981 & Less than $20 \mathrm{kt}$ & 4,510 & 1,099 & 612 & 37.114477 & 116.123751 \\
\hline$U-2 c q$ & 02 & Gorbea & $1 / 31 / 1984$ & 20 to $150 \mathrm{kt}$ & 4,499 & 1,273 & 436 & 37.112649 & 116.122576 \\
\hline$U-2 c r$ & 02 & Wexford & 8/30/1984 & Less than $20 \mathrm{kt}$ & 4,604 & 1,030 & 802 & 37.143841 & 116.126129 \\
\hline$U-2 c s$ & 02 & Maribo & 6/26/1985 & Less than $20 \mathrm{kt}$ & 4,525 & 1,250 & 545 & 37.124049 & 116.122859 \\
\hline
\end{tabular}


Appendix 2. Characteristics of underground nuclear detonations in Yucca Flat and vicinity, Nevada Test Site, 1951-1992 —Continued Land-surface altitude: Altitude in feet above sea level.

Shot distance above water table: Distance in feet. Negative values indicate distance below water table.

[NTS, Nevada Test Site; kt, kiloton; NAD83, North American Datum of 1983; NA, not available. Source of data: U.S. Department of Energy (2000)]

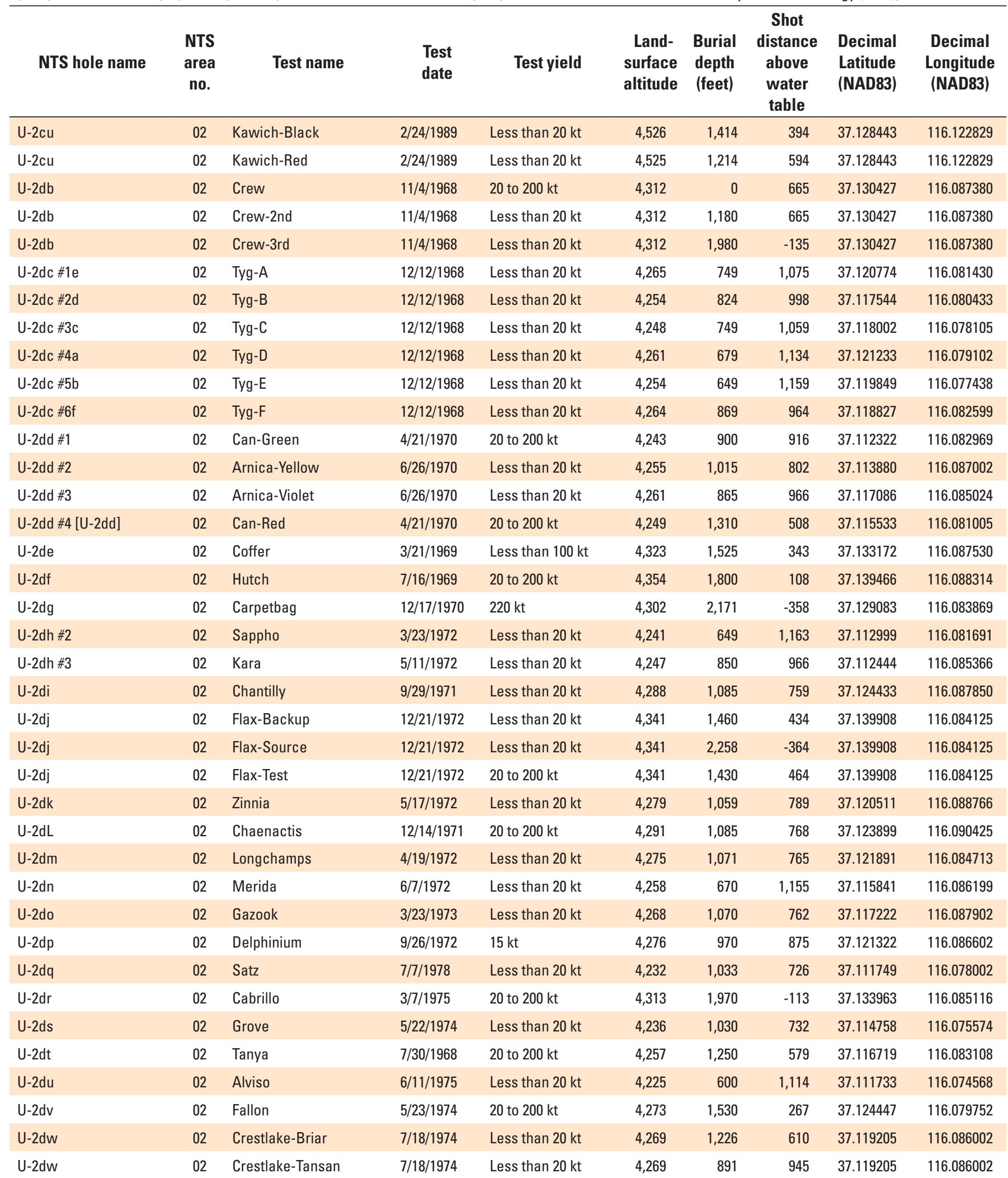


Appendix 2. Characteristics of underground nuclear detonations in Yucca Flat and vicinity, Nevada Test Site, 1951-1992—Continued Land-surface altitude: Altitude in feet above sea level.

Shot distance above water table: Distance in feet. Negative values indicate distance below water table.

[NTS, Nevada Test Site; kt, kiloton; NAD83, North American Datum of 1983; NA, not available. Source of data: U.S. Department of Energy (2000)]

\begin{tabular}{|c|c|c|c|c|c|c|c|c|c|}
\hline NTS hole name & $\begin{array}{c}\text { NTS } \\
\text { area } \\
\text { no. }\end{array}$ & Test name & $\begin{array}{l}\text { Test } \\
\text { date }\end{array}$ & Test yield & $\begin{array}{l}\text { Land- } \\
\text { surface } \\
\text { altitude }\end{array}$ & $\begin{array}{l}\text { Burial } \\
\text { depth } \\
\text { (feet) }\end{array}$ & $\begin{array}{c}\text { Shot } \\
\text { distance } \\
\text { above } \\
\text { water } \\
\text { table }\end{array}$ & $\begin{array}{l}\text { Decimal } \\
\text { Latitude } \\
\text { (NAD83) }\end{array}$ & $\begin{array}{c}\text { Decimal } \\
\text { Longitude } \\
\text { (NAD83) }\end{array}$ \\
\hline U-2dy & 02 & Edam & 4/24/1975 & 20 to $200 \mathrm{kt}$ & 4,263 & 1,350 & 474 & 37.115638 & 116.088261 \\
\hline$U-2 d z$ & 02 & Banon & 8/26/1976 & 20 to $150 \mathrm{kt}$ & 4,273 & 1,760 & 23 & 37.124961 & 116.082866 \\
\hline U-2ea & 02 & Seafoam & $12 / 13 / 1973$ & Less than $20 \mathrm{kt}$ & 4,374 & 650 & 1,303 & 37.161349 & 116.073924 \\
\hline$U-2 e b$ & 02 & Portrero & $4 / 23 / 1974$ & Less than $20 \mathrm{kt}$ & 4,387 & 690 & 1,268 & 37.159924 & 116.077283 \\
\hline U-2ef & 02 & Gouda & 10/6/1976 & Less than $20 \mathrm{kt}$ & 4,260 & 656 & 1,154 & 37.134514 & 116.063146 \\
\hline U-2eg & 02 & Rivoli & $5 / 20 / 1976$ & Less than $20 \mathrm{kt}$ & 4,284 & 656 & 1,178 & 37.137152 & 116.067449 \\
\hline U-2eh & 02 & Liptauer & $4 / 3 / 1980$ & 20 to $150 \mathrm{kt}$ & 4,368 & 1,368 & 552 & 37.149827 & 116.083133 \\
\hline U-2em & 02 & Azul & $12 / 14 / 1979$ & Less than $20 \mathrm{kt}$ & 4,273 & 673 & 1,151 & 37.137325 & 116.063943 \\
\hline U-2en & 02 & Reblochon & 2/23/1978 & 20 to $150 \mathrm{kt}$ & 4,225 & 2,160 & -407 & 37.123630 & 116.064701 \\
\hline U-2eo & 02 & Kloster & 2/15/1979 & 20 to $150 \mathrm{kt}$ & 4,344 & 1,760 & 157 & 37.151963 & 116.072708 \\
\hline U-2ep & 02 & Nessel & 8/29/1979 & 20 to $150 \mathrm{kt}$ & 4,221 & 1,522 & 222 & 37.121172 & 116.067457 \\
\hline U-2eq & 02 & Riola & $9 / 25 / 1980$ & $1.07 \mathrm{kt}$ & 4,203 & 1,391 & 277 & 37.115814 & 116.065438 \\
\hline U-2er & 10 & Islay & 8/27/1981 & Less than $20 \mathrm{kt}$ & 4,342 & 965 & 961 & 37.160369 & 116.067396 \\
\hline U-2es & 02 & Akavi & 12/3/1981 & 20 to $150 \mathrm{kt}$ & 4,332 & 1,621 & 268 & 37.148386 & 116.071710 \\
\hline U-2et & 10 & Cheedam & 2/17/1983 & Less than $20 \mathrm{kt}$ & 4,332 & 1,125 & 794 & 37.162769 & 116.064218 \\
\hline U-2ey & 02 & Rhyolite & $6 / 22 / 1988$ & Less than $150 \mathrm{kt}$ & 4,384 & 680 & 1,288 & 37.166111 & 116.073116 \\
\hline U-2f & 02 & Narraguagus & 9/27/1963 & Low & 4,360 & 493 & 1,439 & 37.154730 & 116.074230 \\
\hline U-2fa & 02 & Farallones & $12 / 14 / 1977$ & 20 to $150 \mathrm{kt}$ & 4,322 & 2,192 & -318 & 37.135822 & 116.086900 \\
\hline$U-2 f b$ & 02 & Quargel & $11 / 18 / 1978$ & 20 to $150 \mathrm{kt}$ & 4,271 & 1,778 & -11 & 37.126822 & 116.084744 \\
\hline$U-2 f c$ & 02 & Fajy & $6 / 28 / 1979$ & 20 to $150 \mathrm{kt}$ & 4,364 & 1,759 & 155 & 37.143116 & 116.088389 \\
\hline$U-2 f d$ & 02 & Tarko & 2/28/1980 & Less than $20 \mathrm{kt}$ & 4,287 & 1,211 & 632 & 37.126499 & 116.089378 \\
\hline U-2fe & 02 & Crowdie & $5 / 5 / 1983$ & Less than $20 \mathrm{kt}$ & 4,383 & 1,280 & 655 & 37.145594 & 116.090089 \\
\hline U-2ff & 02 & Laban & $8 / 3 / 1983$ & Less than $20 \mathrm{kt}$ & 4,275 & 1,070 & 771 & 37.118949 & 116.089778 \\
\hline$U-2 g$ & 02 & Satsop & $8 / 15 / 1963$ & Low & 4,373 & 742 & 1,197 & 37.154044 & 116.077499 \\
\hline U-2gaS & 02 & Cornucopia & $7 / 24 / 1986$ & Less than $20 \mathrm{kt}$ & 4,312 & 1,250 & 608 & 37.142699 & 116.071988 \\
\hline$U-2 g b$ & 02 & Panamint & $5 / 21 / 1986$ & Less than $20 \mathrm{kt}$ & 4,219 & 1,575 & 159 & 37.124986 & 116.061259 \\
\hline $\mathrm{U}-2 \mathrm{ge}$ & 02 & Borate & 10/23/1987 & 20 to $150 \mathrm{kt}$ & 4,335 & 1,780 & 99 & 37.141849 & 116.079572 \\
\hline U-2gf & 02 & Schellbourne & $5 / 13 / 1988$ & Less than $150 \mathrm{kt}$ & 4,249 & 1,519 & 255 & 37.124386 & 116.072996 \\
\hline
\end{tabular}


Appendix 2. Characteristics of underground nuclear detonations in Yucca Flat and vicinity, Nevada Test Site, 1951-1992—Continued Land-surface altitude: Altitude in feet above sea level.

Shot distance above water table: Distance in feet. Negative values indicate distance below water table.

[NTS, Nevada Test Site; kt, kiloton; NAD83, North American Datum of 1983; NA, not available. Source of data: U.S. Department of Energy (2000)]

\begin{tabular}{|c|c|c|c|c|c|c|c|c|c|}
\hline NTS hole name & $\begin{array}{c}\text { NTS } \\
\text { area } \\
\text { no. }\end{array}$ & Test name & $\begin{array}{l}\text { Test } \\
\text { date }\end{array}$ & Test yield & $\begin{array}{l}\text { Land- } \\
\text { surface } \\
\text { altitude }\end{array}$ & $\begin{array}{l}\text { Burial } \\
\text { depth } \\
\text { (feet) }\end{array}$ & $\begin{array}{c}\text { Shot } \\
\text { distance } \\
\text { above } \\
\text { water } \\
\text { table }\end{array}$ & $\begin{array}{l}\text { Decimal } \\
\text { Latitude } \\
\text { (NAD83) }\end{array}$ & $\begin{array}{c}\text { Decimal } \\
\text { Longitude } \\
\text { (NAD83) }\end{array}$ \\
\hline U-2gg & 02 & Ingot & $3 / 9 / 1989$ & 20 to $150 \mathrm{kt}$ & 4,289 & 1,640 & 209 & 37.142791 & 116.067807 \\
\hline U-2gh & 02 & Metropolis & 3/10/1990 & 20 to $150 \mathrm{kt}$ & 4,177 & 1,540 & 32 & 37.112455 & 116.056048 \\
\hline U-2j Shaft & 02 & Alva & 8/19/1964 & $4.4 \mathrm{kt}$ & 4,420 & 545 & 1,429 & 37.158969 & 116.083969 \\
\hline U-2L & 02 & Ahtanum & $9 / 13 / 1963$ & Low & 4,419 & 742 & 1,238 & 37.163322 & 116.081511 \\
\hline $\begin{array}{l}\text { U-2m \#1 Emplacement } \\
\text { Hole }\end{array}$ & 02 & Fenton & 4/23/1966 & $1.4 \mathrm{kt}$ & 4,423 & 549 & 1,423 & 37.160491 & 116.083744 \\
\hline$U-2 n$ & 02 & Ace & $6 / 11 / 1964$ & $3 \mathrm{kt}$ & 4,353 & 864 & 1,026 & 37.148555 & 116.076866 \\
\hline$U-2 t$ & 04 & Dumont & $5 / 19 / 1966$ & 20 to $200 \mathrm{kt}$ & 4,195 & 2,201 & -606 & 37.111103 & 116.058798 \\
\hline$U-2 u$ & 02 & Packard & 1/15/1969 & $10 \mathrm{kt}$ & 4,315 & 810 & 1,075 & 37.147869 & 116.066529 \\
\hline$U-2 v$ & 02 & Agile & 2/23/1967 & 20 to $200 \mathrm{kt}$ & 4,256 & 2,406 & -623 & 37.126802 & 116.067249 \\
\hline$U-2 x$ & 02 & Lanpher & 10/18/1967 & 20 to $200 \mathrm{kt}$ & 4,206 & 2,346 & -711 & 37.115539 & 116.058507 \\
\hline U-2y & 02 & Hupmobile & 1/18/1968 & $7.4 \mathrm{kt}$ & 4,310 & 810 & 1,069 & 37.145533 & 116.066549 \\
\hline U3aа & 03 & Boomer & 10/1/1961 & Low & 4,027 & 330 & 1,293 & 37.048294 & 116.035380 \\
\hline U-3ab & 03 & Ermine & $3 / 6 / 1962$ & Low & 4,028 & 240 & 1,383 & 37.048350 & 116.034527 \\
\hline U-3ac & 03 & Shrew & 9/16/1961 & Low & 4,027 & 322 & 1,300 & 37.048408 & 116.033671 \\
\hline U-3ajS & 03 & Raccoon & $6 / 1 / 1962$ & Low & 4,021 & 539 & 1,077 & 37.045567 & 116.035330 \\
\hline U-3ak & 03 & Ringtail & 12/17/1961 & Low & 4,014 & 1,191 & 417 & 37.043114 & 116.026182 \\
\hline U-3aL & 03 & Pampas & $3 / 1 / 1962$ & $9.5 \mathrm{kt}$ & 4,012 & 1,191 & 416 & 37.041217 & 116.029549 \\
\hline U-3amS & 03 & Aardvark & $5 / 12 / 1962$ & $40 \mathrm{kt}$ & 4,071 & 1,424 & 227 & 37.065144 & 116.031246 \\
\hline U-3an & 03 & Wagtail & 3/3/1965 & 20 to $200 \mathrm{kt}$ & 4,060 & 2,459 & -845 & 37.064464 & 116.038049 \\
\hline U-3ao & 03 & Agouti & 1/18/1962 & 6.4 kt & 4,027 & 856 & 766 & 37.047200 & 116.035233 \\
\hline U-3ap & 03 & Stoat & 1/9/1962 & $5.1 \mathrm{kt}$ & 4,021 & 992 & 624 & 37.044592 & 116.035933 \\
\hline U-3aq & 03 & Dormouse & 1/30/1962 & Low & 4,026 & 1,191 & 427 & 37.046800 & 116.040352 \\
\hline U-3ar & 03 & Armadillo & 2/9/1962 & $7.1 \mathrm{kt}$ & 4,019 & 786 & 827 & 37.043530 & 116.039827 \\
\hline U-3as & 03 & Chinchilla II & $3 / 31 / 1962$ & Low & 4,026 & 448 & 1,172 & 37.046861 & 116.037769 \\
\hline U-3at & 03 & Jerboa & $3 / 1 / 1963$ & Low & 4,015 & 988 & 622 & 37.044464 & 116.027363 \\
\hline U-3auS & 03 & Haymaker & $6 / 27 / 1962$ & $67 \mathrm{kt}$ & 4,013 & 1,340 & 270 & 37.041550 & 116.036113 \\
\hline U-3av & 03 & Wolverine & $10 / 12 / 1962$ & Low & 4,027 & 241 & 1,381 & 37.048733 & 116.033427 \\
\hline U-3aw & 03 & Packrat & 6/6/1962 & Low & 4,022 & 860 & 755 & 37.045669 & 116.040155 \\
\hline
\end{tabular}


Appendix 2. Characteristics of underground nuclear detonations in Yucca Flat and vicinity, Nevada Test Site, 1951-1992—Continued Land-surface altitude: Altitude in feet above sea level.

Shot distance above water table: Distance in feet. Negative values indicate distance below water table.

[NTS, Nevada Test Site; kt, kiloton; NAD83, North American Datum of 1983; NA, not available. Source of data: U.S. Department of Energy (2000)]

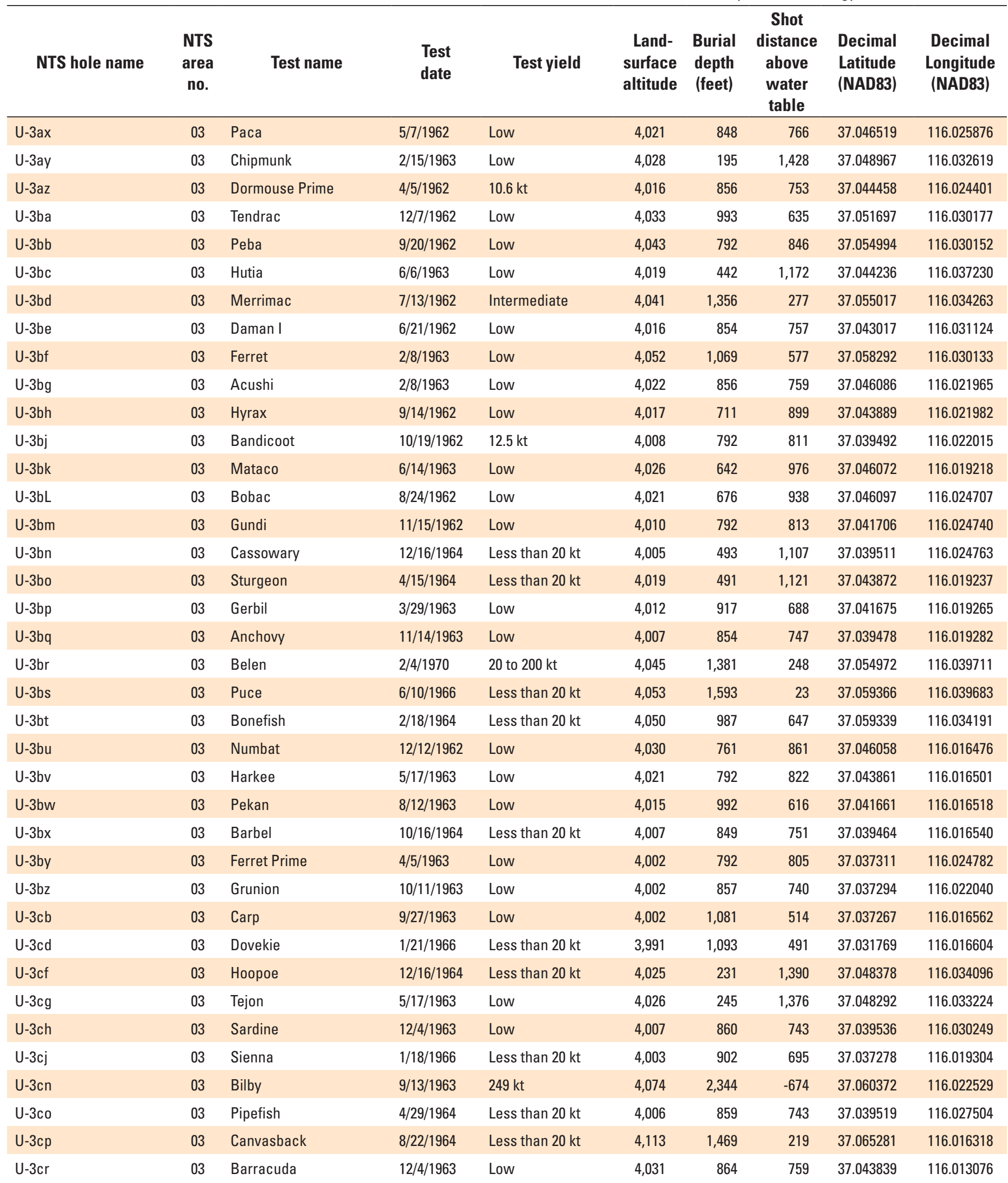


Appendix 2. Characteristics of underground nuclear detonations in Yucca Flat and vicinity, Nevada Test Site, 1951-1992—Continued Land-surface altitude: Altitude in feet above sea level.

Shot distance above water table: Distance in feet. Negative values indicate distance below water table.

[NTS, Nevada Test Site; kt, kiloton; NAD83, North American Datum of 1983; NA, not available. Source of data: U.S. Department of Energy (2000)]

\begin{tabular}{|c|c|c|c|c|c|c|c|c|c|}
\hline NTS hole name & $\begin{array}{c}\text { NTS } \\
\text { area } \\
\text { no. }\end{array}$ & Test name & $\begin{array}{l}\text { Test } \\
\text { date }\end{array}$ & Test yield & $\begin{array}{l}\text { Land- } \\
\text { surface } \\
\text { altitude }\end{array}$ & $\begin{array}{l}\text { Burial } \\
\text { depth } \\
\text { (feet) }\end{array}$ & $\begin{array}{c}\text { Shot } \\
\text { distance } \\
\text { above } \\
\text { water } \\
\text { table }\end{array}$ & $\begin{array}{l}\text { Decimal } \\
\text { Latitude } \\
\text { (NAD83) }\end{array}$ & $\begin{array}{l}\text { Decimal } \\
\text { Longitude } \\
\text { (NAD83) }\end{array}$ \\
\hline U-3ct & 03 & Merlin & 2/16/1965 & $10.1 \mathrm{kt}$ & 4,037 & 972 & 659 & 37.051594 & 116.024665 \\
\hline U-3cu & 03 & Bitterling & $6 / 12 / 1964$ & Less than $20 \mathrm{kt}$ & 4,013 & 632 & 999 & 37.038897 & 116.013120 \\
\hline U-3cx & 03 & Cyclamen & $5 / 5 / 1966$ & $12 \mathrm{kt}$ & 4,036 & 1,001 & 627 & 37.050572 & 116.038719 \\
\hline U-3cy & 03 & Pike & $3 / 13 / 1964$ & Less than $20 \mathrm{kt}$ & 4,060 & 376 & 1,269 & 37.050422 & 116.012331 \\
\hline U-3cz & 03 & Solendon & 2/12/1964 & Less than $20 \mathrm{kt}$ & 4,046 & 493 & 1,148 & 37.056564 & 116.030110 \\
\hline U-3d & 03 & Pascal-B & 8/27/1957 & Slight & 4,028 & 500 & 1,123 & 37.049011 & 116.034827 \\
\hline U-3daS & 03 & Scaup & $5 / 14 / 1965$ & Less than $20 \mathrm{kt}$ & 4,098 & 1,401 & 261 & 37.058797 & 116.011409 \\
\hline U-3df & 03 & Cormorant & $7 / 17 / 1964$ & Less than $20 \mathrm{kt}$ & 3,975 & 891 & 677 & 37.017564 & 116.030426 \\
\hline U-3dg & 03 & Screamer & $9 / 1 / 1965$ & Less than $20 \mathrm{kt}$ & 3,975 & 990 & 578 & 37.022944 & 116.009828 \\
\hline U-3dh & 07 & Buff & $12 / 16 / 1965$ & 20 to $200 \mathrm{kt}$ & 4,102 & 1,642 & 47 & 37.072497 & 116.029969 \\
\hline U-3di & 03 & Guanay & $9 / 4 / 1964$ & Less than $20 \mathrm{kt}$ & 3,975 & 856 & 711 & 37.017528 & 116.023573 \\
\hline U-3dj & 03 & Trogon & $7 / 24 / 1964$ & Less than $20 \mathrm{kt}$ & 4,039 & 633 & 997 & 37.046036 & 116.013054 \\
\hline U-3dk & 03 & Parrot & $12 / 16 / 1964$ & $1.3 \mathrm{kt}$ & 4,001 & 592 & 1,001 & 37.034775 & 116.013151 \\
\hline U-3dL & 03 & Haddock & 8/28/1964 & Less than $20 \mathrm{kt}$ & 4,097 & 1,193 & 497 & 37.066969 & 116.023154 \\
\hline U-3dm & 03 & Cinnamon & $3 / 7 / 1966$ & Less than $20 \mathrm{kt}$ & 4,000 & 393 & 1,204 & 37.034600 & 116.031660 \\
\hline U-3du & 03 & Finfoot & 3/7/1966 & Less than $20 \mathrm{kt}$ & 4,003 & 642 & 959 & 37.037339 & 116.030263 \\
\hline U-3dw & 03 & Tern & 1/29/1965 & Less than $20 \mathrm{kt}$ & 4,032 & 691 & 933 & 37.044944 & 116.014095 \\
\hline U-3dx & 03 & Muscovy & 4/23/1965 & Less than $20 \mathrm{kt}$ & 3,991 & 592 & 990 & 37.017373 & 115.996175 \\
\hline U-3dy & 03 & Petrel & $6 / 11 / 1965$ & $1.3 \mathrm{kt}$ & 4,016 & 593 & 1,016 & 37.042764 & 116.017884 \\
\hline U-3dz & 03 & Knife B & $11 / 15 / 1968$ & Less than $20 \mathrm{kt}$ & 3,987 & 1,191 & 390 & 37.026100 & 116.034129 \\
\hline U-3e & 03 & Pascal-C & 12/6/1957 & Slight & 4,031 & 250 & 1,376 & 37.049894 & 116.031735 \\
\hline U-3eb & 03 & Tangerine & 8/12/1966 & Less than $20 \mathrm{kt}$ & 4,021 & 288 & 1,327 & 37.046264 & 116.030188 \\
\hline U-3ec & 03 & Ochre & 4/29/1966 & Less than $20 \mathrm{kt}$ & 4,013 & 414 & 1,192 & 37.043619 & 116.023357 \\
\hline U-3ed & 03 & Moa & $9 / 1 / 1965$ & Less than $20 \mathrm{kt}$ & 4,005 & 635 & 963 & 37.037256 & 116.014845 \\
\hline U-3ee & 03 & Pommard & $3 / 14 / 1968$ & $1.5 \mathrm{kt}$ & 4,053 & 686 & 957 & 37.047678 & 116.011676 \\
\hline U-3ef & 03 & Mushroom & $3 / 3 / 1967$ & Less than $20 \mathrm{kt}$ & 4,019 & 589 & 1,022 & 37.039433 & 116.011062 \\
\hline U-3eh & 03 & Futtock & 6/18/1975 & Less than $20 \mathrm{kt}$ & 4,094 & 610 & 1,075 & 37.065592 & 116.022829 \\
\hline U-3ei & 07 & Morrones & $5 / 21 / 1970$ & 20 to $200 \mathrm{kt}$ & 4,148 & 1,584 & 115 & 37.070761 & 116.013874 \\
\hline
\end{tabular}


Appendix 2. Characteristics of underground nuclear detonations in Yucca Flat and vicinity, Nevada Test Site, 1951-1992—Continued Land-surface altitude: Altitude in feet above sea level.

Shot distance above water table: Distance in feet. Negative values indicate distance below water table.

[NTS, Nevada Test Site; kt, kiloton; NAD83, North American Datum of 1983; NA, not available. Source of data: U.S. Department of Energy (2000)]

\begin{tabular}{|c|c|c|c|c|c|c|c|c|c|}
\hline NTS hole name & $\begin{array}{c}\text { NTS } \\
\text { area } \\
\text { no. }\end{array}$ & Test name & $\begin{array}{l}\text { Test } \\
\text { date }\end{array}$ & Test yield & $\begin{array}{l}\text { Land- } \\
\text { surface } \\
\text { altitude }\end{array}$ & $\begin{array}{l}\text { Burial } \\
\text { depth } \\
\text { (feet) }\end{array}$ & $\begin{array}{c}\text { Shot } \\
\text { distance } \\
\text { above } \\
\text { water } \\
\text { table }\end{array}$ & $\begin{array}{l}\text { Decimal } \\
\text { Latitude } \\
\text { (NAD83) }\end{array}$ & $\begin{array}{l}\text { Decimal } \\
\text { Longitude } \\
\text { (NAD83) }\end{array}$ \\
\hline U-3ej & 03 & Vise & $1 / 30 / 1969$ & 20 to $200 \mathrm{kt}$ & 4,038 & 1,490 & 143 & 37.053269 & 116.030129 \\
\hline U-3ek & 03 & Tomato & 4/7/1966 & Less than $20 \mathrm{kt}$ & 4,010 & 742 & 861 & 37.017361 & 115.993091 \\
\hline U-3em & 03 & Umber & 6/29/1967 & $10 \mathrm{kt}$ & 3,988 & 1,018 & 564 & 37.028519 & 116.023487 \\
\hline U-3en & 03 & Sepia & $11 / 12 / 1965$ & Less than $20 \mathrm{kt}$ & 4,033 & 791 & 835 & 37.049936 & 116.022963 \\
\hline U-3eo & 03 & Fawn & $4 / 7 / 1967$ & Less than $20 \mathrm{kt}$ & 4,047 & 889 & 751 & 37.054328 & 116.023096 \\
\hline U-3ep & 03 & Absinthe & $5 / 26 / 1967$ & Less than $20 \mathrm{kt}$ & 4,022 & 389 & 1,225 & 37.044975 & 116.019918 \\
\hline U-3eq & 03 & Brush & $1 / 24 / 1968$ & Less than $20 \mathrm{kt}$ & 4,021 & 388 & 1,225 & 37.042747 & 116.014798 \\
\hline U-3eu & 03 & Cerise & $11 / 18 / 1966$ & Less than $20 \mathrm{kt}$ & 4,031 & 693 & 929 & 37.042728 & 116.011201 \\
\hline U-3ev-2S Zero Station & 03 & Snubber & 4/21/1970 & $12.7 \mathrm{kt}$ & 4,199 & 1,127 & 680 & 37.054842 & 115.988992 \\
\hline U-3ew & 03 & Gibson & $8 / 4 / 1967$ & Less than $20 \mathrm{kt}$ & 3,980 & 790 & 781 & 37.024339 & 116.013239 \\
\hline U-3ex & 03 & Gilroy & 9/15/1967 & Less than $20 \mathrm{kt}$ & 3,998 & 789 & 803 & 37.034822 & 116.021715 \\
\hline U-3ey & 03 & Wembley & 6/5/1968 & Less than $20 \mathrm{kt}$ & 3,998 & 781 & 810 & 37.034794 & 116.016923 \\
\hline U-3ez & 03 & Sidecar & $12 / 13 / 1966$ & Less than $20 \mathrm{kt}$ & 4,010 & 788 & 817 & 37.034742 & 116.007667 \\
\hline U-3fa & 03 & Sazerac & 10/25/1967 & Less than $20 \mathrm{kt}$ & 3,995 & 989 & 601 & 37.031558 & 116.027224 \\
\hline U-3fb & 03 & Knife A & $9 / 12 / 1968$ & Less than $20 \mathrm{kt}$ & 3,994 & 1,089 & 497 & 37.031750 & 116.012498 \\
\hline U-3fk & 03 & Sevilla & 6/25/1968 & Less than $20 \mathrm{kt}$ & 4,111 & 1,177 & 516 & 37.041531 & 115.993219 \\
\hline U-3fm & 03 & Cognac & 10/25/1967 & Less than $20 \mathrm{kt}$ & 4,034 & 789 & 836 & 37.049750 & 116.040444 \\
\hline U-3fn & 03 & Beebalm & $5 / 1 / 1970$ & Less than $20 \mathrm{kt}$ & 4,054 & 1,280 & 369 & 37.059169 & 116.029052 \\
\hline U-3fq & 07 & Canjilon & 12/16/1970 & Less than $20 \mathrm{kt}$ & 4,116 & 991 & 720 & 37.072475 & 116.025860 \\
\hline U-3fr & 03 & Fizz & $3 / 10 / 1967$ & Less than $20 \mathrm{kt}$ & 4,022 & 386 & 1,230 & 37.047314 & 116.030635 \\
\hline U-3fs & 03 & Welder & 10/3/1968 & Less than $20 \mathrm{kt}$ & 4,022 & 386 & 1,230 & 37.046478 & 116.030607 \\
\hline U-3fu & 03 & Bevel & 4/4/1968 & Less than $20 \mathrm{kt}$ & 4,043 & 790 & 845 & 37.052264 & 116.021743 \\
\hline U-3fv & 03 & Mallet & $1 / 31 / 1968$ & Less than $20 \mathrm{kt}$ & 3,951 & 788 & 738 & 37.000975 & 116.010017 \\
\hline U-3fw & 03 & Adze & $5 / 28 / 1968$ & Less than $20 \mathrm{kt}$ & 3,987 & 788 & 772 & 37.008586 & 115.996255 \\
\hline U-3fx & 03 & Auger & $11 / 15 / 1968$ & Less than $20 \mathrm{kt}$ & 4,097 & 789 & 873 & 37.047617 & 116.000706 \\
\hline U-3fy & 06 & Spud & 7/17/1968 & Less than $20 \mathrm{kt}$ & 3,956 & 788 & 733 & 37.000911 & 115.999744 \\
\hline U-3fz & 03 & Hatchet & $5 / 3 / 1968$ & Less than $20 \mathrm{kt}$ & 3,987 & 789 & 792 & 37.028500 & 116.020743 \\
\hline U-3ga & 03 & Funnel & $6 / 25 / 1968$ & Less than $20 \mathrm{kt}$ & 4,023 & 389 & 1,229 & 37.046303 & 116.031077 \\
\hline
\end{tabular}


Appendix 2. Characteristics of underground nuclear detonations in Yucca Flat and vicinity, Nevada Test Site, 1951-1992 —Continued Land-surface altitude: Altitude in feet above sea level.

Shot distance above water table: Distance in feet. Negative values indicate distance below water table.

[NTS, Nevada Test Site; kt, kiloton; NAD83, North American Datum of 1983; NA, not available. Source of data: U.S. Department of Energy (2000)]

\begin{tabular}{|c|c|c|c|c|c|c|c|c|c|}
\hline NTS hole name & $\begin{array}{c}\text { NTS } \\
\text { area } \\
\text { no. }\end{array}$ & Test name & $\begin{array}{l}\text { Test } \\
\text { date }\end{array}$ & Test yield & $\begin{array}{l}\text { Land- } \\
\text { surface } \\
\text { altitude }\end{array}$ & $\begin{array}{l}\text { Burial } \\
\text { depth } \\
\text { (feet) }\end{array}$ & $\begin{array}{c}\text { Shot } \\
\text { distance } \\
\text { above } \\
\text { water } \\
\text { table }\end{array}$ & $\begin{array}{l}\text { Decimal } \\
\text { Latitude } \\
\text { (NAD83) }\end{array}$ & $\begin{array}{c}\text { Decimal } \\
\text { Longitude } \\
\text { (NAD83) }\end{array}$ \\
\hline U-3gb & 03 & File & $10 / 31 / 1968$ & Less than $20 \mathrm{kt}$ & 3,977 & 751 & 820 & 37.017047 & 116.036599 \\
\hline U-3gc & 03 & Barsac & 3/20/1969 & Less than $20 \mathrm{kt}$ & 3,982 & 998 & 577 & 37.021961 & 116.031076 \\
\hline U-3ge & 03 & Sapello & 4/12/1974 & Less than $20 \mathrm{kt}$ & 3,989 & 593 & 990 & 37.014894 & 116.045008 \\
\hline U-3gf & 03 & Winch & 2/4/1969 & Less than $20 \mathrm{kt}$ & 3,977 & 789 & 783 & 37.009391 & 116.043169 \\
\hline U-3gg & 03 & Tortugas & $3 / 1 / 1984$ & 20 to $150 \mathrm{kt}$ & 4,079 & 2,100 & -541 & 37.065719 & 116.047164 \\
\hline U-3gh & 03 & Scissors & $12 / 12 / 1968$ & Less than $20 \mathrm{kt}$ & 3,965 & 789 & 770 & 37.003880 & 116.040135 \\
\hline U-3gi & 03 & Tuloso & 12/12/1972 & Less than $20 \mathrm{kt}$ & 3,991 & 889 & 696 & 37.031253 & 116.022096 \\
\hline U-3gm & 06 & Horehound & $8 / 27 / 1969$ & Less than $20 \mathrm{kt}$ & 3,942 & 1,089 & 421 & 36.992656 & 115.996397 \\
\hline U-3gn & 03 & Pliers & $8 / 27 / 1969$ & Less than $20 \mathrm{kt}$ & 3,984 & 784 & 795 & 37.021455 & 116.038960 \\
\hline U-3go & 03 & Tapper & $6 / 12 / 1969$ & Less than $20 \mathrm{kt}$ & 3,965 & 994 & 563 & 37.008778 & 116.031185 \\
\hline U-3gq & 03 & Bay Leaf & $12 / 12 / 1968$ & Less than $20 \mathrm{kt}$ & 4,023 & 427 & 1,191 & 37.046989 & 116.031068 \\
\hline U-3gr & 03 & Manzanas & $5 / 21 / 1970$ & Less than $20 \mathrm{kt}$ & 4,008 & 790 & 801 & 37.012139 & 115.992814 \\
\hline U-3gs & 03 & Apodaca & $7 / 21 / 1971$ & Less than $20 \mathrm{kt}$ & 4,009 & 792 & 807 & 37.014334 & 115.992794 \\
\hline U-3gt & 03 & Bit-A & 10/31/1968 & Less than $20 \mathrm{kt}$ & 4,022 & 487 & 1,129 & 37.046983 & 116.030332 \\
\hline U-3gt & 03 & Bit-B & $10 / 31 / 1968$ & Less than $20 \mathrm{kt}$ & 4,022 & 387 & 1,229 & 37.046983 & 116.030332 \\
\hline U-3hc & 03 & Sprit & 11/10/1976 & Less than $20 \mathrm{kt}$ & 4,000 & 600 & 992 & 37.035903 & 116.018282 \\
\hline U-3hd & 03 & Embudo & 6/16/1971 & Less than $20 \mathrm{kt}$ & 3,996 & 994 & 594 & 37.033133 & 116.014537 \\
\hline U-3he & 03 & Barranca & 8/4/1971 & Less than $20 \mathrm{kt}$ & 3,984 & 888 & 689 & 37.026025 & 116.020423 \\
\hline U-3hf & 03 & Frijoles-Guaje & $9 / 22 / 1971$ & Less than $20 \mathrm{kt}$ & 3,980 & 843 & 729 & 37.024353 & 116.016154 \\
\hline U-3hg & 03 & Pedernal & 9/29/1971 & Less than $20 \mathrm{kt}$ & 3,961 & 1,242 & 300 & 37.010989 & 116.008220 \\
\hline U-3hh & 06 & Jal & 3/19/1970 & Less than $20 \mathrm{kt}$ & 3,955 & 989 & 549 & 37.001047 & 116.023715 \\
\hline U-3hi-a & 03 & Culantro-A & 12/10/1969 & Less than $20 \mathrm{kt}$ & 3,964 & 440 & 1,109 & 37.014672 & 116.003733 \\
\hline U-3hi-b & 03 & Culantro-B & $12 / 10 / 1969$ & Less than $20 \mathrm{kt}$ & 3,967 & 490 & 1,062 & 37.014864 & 116.002019 \\
\hline U-3hj & 03 & Scupper & 8/19/1977 & Less than $20 \mathrm{kt}$ & 3,976 & 1,475 & 94 & 37.017575 & 116.032482 \\
\hline U-3hk-a & 03 & Ipecac-A & $5 / 27 / 1969$ & Less than $20 \mathrm{kt}$ & 3,965 & 407 & 1,143 & 37.014942 & 116.003044 \\
\hline U-3hk-b & 03 & Ipecac-B & $5 / 27 / 1969$ & Less than $20 \mathrm{kt}$ & 3,968 & 408 & 1,145 & 37.014792 & 116.000994 \\
\hline U-3hk-c & 03 & Seaweed-E & 10/1/1969 & Less than $20 \mathrm{kt}$ & 3,974 & 408 & 1,148 & 37.013686 & 115.999464 \\
\hline U-3hk-d & 03 & Seaweed B & 10/16/1969 & Less than $20 \mathrm{kt}$ & 3,976 & 389 & 1,167 & 37.012531 & 115.999131 \\
\hline
\end{tabular}


Appendix 2. Characteristics of underground nuclear detonations in Yucca Flat and vicinity, Nevada Test Site, 1951-1992—Continued Land-surface altitude: Altitude in feet above sea level.

Shot distance above water table: Distance in feet. Negative values indicate distance below water table.

[NTS, Nevada Test Site; kt, kiloton; NAD83, North American Datum of 1983; NA, not available. Source of data: U.S. Department of Energy (2000)]

\begin{tabular}{|c|c|c|c|c|c|c|c|c|c|}
\hline NTS hole name & $\begin{array}{c}\text { NTS } \\
\text { area } \\
\text { no. }\end{array}$ & Test name & $\begin{array}{l}\text { Test } \\
\text { date }\end{array}$ & Test yield & $\begin{array}{l}\text { Land- } \\
\text { surface } \\
\text { altitude }\end{array}$ & $\begin{array}{l}\text { Burial } \\
\text { depth } \\
\text { (feet) }\end{array}$ & $\begin{array}{c}\text { Shot } \\
\text { distance } \\
\text { above } \\
\text { water } \\
\text { table }\end{array}$ & $\begin{array}{l}\text { Decimal } \\
\text { Latitude } \\
\text { (NAD83) }\end{array}$ & $\begin{array}{l}\text { Decimal } \\
\text { Longitude } \\
\text { (NAD83) }\end{array}$ \\
\hline U-3hk-e & 03 & Seaweed-C & $10 / 1 / 1969$ & Less than $20 \mathrm{kt}$ & 3,975 & 389 & 1,163 & 37.011378 & 115.999486 \\
\hline U-3hk-f & 03 & Seaweed-D & 10/1/1969 & Less than $20 \mathrm{kt}$ & 3,971 & 389 & 1,159 & 37.010461 & 116.000436 \\
\hline U-3hm & 03 & Truchas-Rodarte & 10/28/1970 & Less than $20 \mathrm{kt}$ & 3,970 & 874 & 687 & 37.014761 & 116.020176 \\
\hline U-3hn & 03 & Truchas-Chacon & 10/28/1970 & Less than $20 \mathrm{kt}$ & 3,968 & 389 & 1,169 & 37.013969 & 116.018812 \\
\hline U-3ho & 03 & Truchas-Chamisal & 10/28/1970 & Less than $20 \mathrm{kt}$ & 3,968 & 388 & 1,170 & 37.013967 & 116.018126 \\
\hline U-3hp & 03 & Jara & 6/6/1974 & Less than $20 \mathrm{kt}$ & 3,960 & 1,240 & 305 & 37.003797 & 116.024379 \\
\hline U-3hq & 03 & Pratt & 9/25/1974 & Less than $20 \mathrm{kt}$ & 3,970 & 1,028 & 532 & 37.012075 & 116.031160 \\
\hline U-3hu & 03 & Keel & 12/16/1974 & Less than $20 \mathrm{kt}$ & 3,966 & 1,001 & 553 & 37.011253 & 116.018495 \\
\hline U-3hv & 03 & Colmor & $4 / 26 / 1973$ & Less than $20 \mathrm{kt}$ & 3,968 & 806 & 751 & 37.012100 & 116.020834 \\
\hline U-3hx & 03 & Cowles & 2/3/1972 & Less than $20 \mathrm{kt}$ & 3,955 & 990 & 546 & 37.001028 & 116.020293 \\
\hline U-3hy & 03 & Elida & 12/19/1973 & Less than $20 \mathrm{kt}$ & 3,955 & 1,250 & 294 & 37.001094 & 116.032276 \\
\hline U-3hz & 03 & Frijoles-Petaca & 9/22/1971 & Less than $20 \mathrm{kt}$ & 3,980 & 752 & 832 & NA & NA \\
\hline U-3j & 03 & Pascal-A & $7 / 26 / 1957$ & Slight & 4,033 & 500 & 1,127 & 37.051722 & 116.034288 \\
\hline U-3ja & 03 & Estaca & 10/17/1974 & Less than $20 \mathrm{kt}$ & 3,959 & 1,051 & 488 & 37.006356 & 116.015723 \\
\hline U-3jb & 03 & Bobstay & 10/26/1977 & Less than $20 \mathrm{kt}$ & 3,961 & 1,250 & 294 & 37.007553 & 116.017573 \\
\hline U-3ji & 06 & Pajara & 12/12/1973 & Less than $20 \mathrm{kt}$ & 3,945 & 912 & 612 & 36.991442 & 116.024995 \\
\hline U-3jj & 06 & Capitan & 6/28/1972 & Less than $20 \mathrm{kt}$ & 3,946 & 441 & 1,083 & 36.992556 & 116.023018 \\
\hline U-3jk & 06 & Velarde & $4 / 25 / 1973$ & Less than $20 \mathrm{kt}$ & 3,947 & 908 & 618 & 36.993608 & 116.021912 \\
\hline U-3jL & 03 & Puye & 8/14/1974 & Less than $20 \mathrm{kt}$ & 3,987 & 1,411 & 171 & 37.023366 & 116.037229 \\
\hline U-3jm & 03 & Jicarilla & 4/19/1972 & Less than $20 \mathrm{kt}$ & 3,960 & 486 & 1,057 & 37.006567 & 116.017473 \\
\hline U-3jn & 03 & Algodones & 8/18/1971 & 20 to $200 \mathrm{kt}$ & 4,046 & 1,731 & -102 & 37.057142 & 116.037199 \\
\hline U-3jp & 03 & Ocate & $3 / 30 / 1972$ & Less than $20 \mathrm{kt}$ & 3,958 & 689 & 849 & 37.004444 & 116.015739 \\
\hline U-3jq & 03 & Monero & $5 / 19 / 1972$ & Less than $20 \mathrm{kt}$ & 4,175 & 1,763 & -50 & 37.064656 & 116.002614 \\
\hline U-3jr & 03 & Spar & 12/19/1973 & Less than $20 \mathrm{kt}$ & 3,960 & 490 & 1,057 & 37.005722 & 116.019762 \\
\hline U-3js & 03 & Onaja & 3/30/1972 & Less than $20 \mathrm{kt}$ & 3,960 & 915 & 629 & 37.005428 & 116.020940 \\
\hline U-3jt & 03 & Cuchillo & 8/9/1972 & Less than $20 \mathrm{kt}$ & 3,957 & 651 & 888 & 37.003706 & 116.019923 \\
\hline U-3ju & 03 & Frijoles-Espuela & $9 / 22 / 1971$ & Less than $20 \mathrm{kt}$ & 3,979 & 490 & 1,081 & 37.022656 & 116.017195 \\
\hline U-3jv & 03 & Rib & 12/14/1977 & Less than $20 \mathrm{kt}$ & 3,973 & 700 & 866 & 37.017503 & 116.018779 \\
\hline
\end{tabular}


Appendix 2. Characteristics of underground nuclear detonations in Yucca Flat and vicinity, Nevada Test Site, 1951-1992 —Continued Land-surface altitude: Altitude in feet above sea level.

Shot distance above water table: Distance in feet. Negative values indicate distance below water table.

[NTS, Nevada Test Site; kt, kiloton; NAD83, North American Datum of 1983; NA, not available. Source of data: U.S. Department of Energy (2000)]

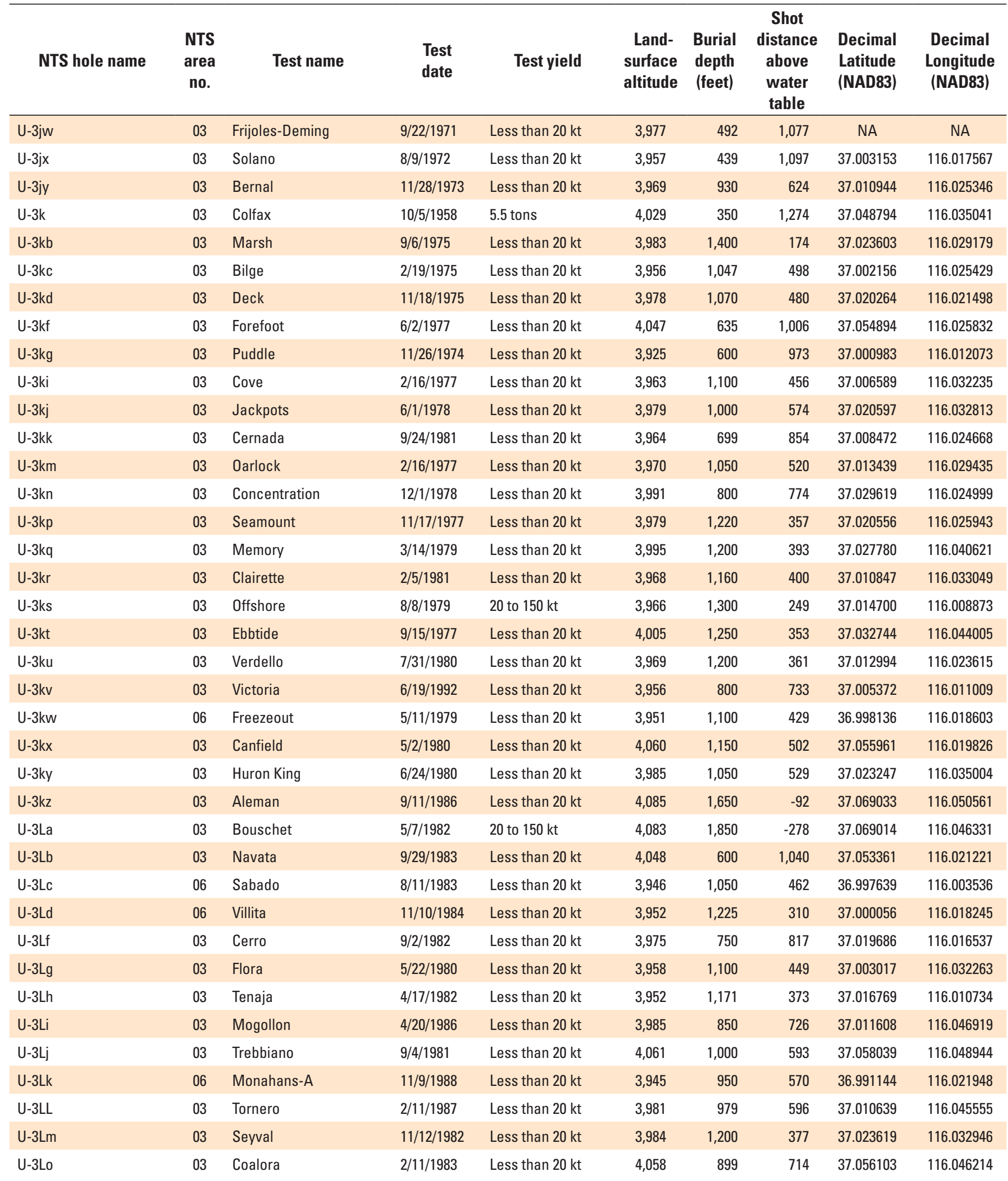


Appendix 2. Characteristics of underground nuclear detonations in Yucca Flat and vicinity, Nevada Test Site, 1951-1992—Continued Land-surface altitude: Altitude in feet above sea level.

Shot distance above water table: Distance in feet. Negative values indicate distance below water table.

[NTS, Nevada Test Site; kt, kiloton; NAD83, North American Datum of 1983; NA, not available. Source of data: U.S. Department of Energy (2000)]

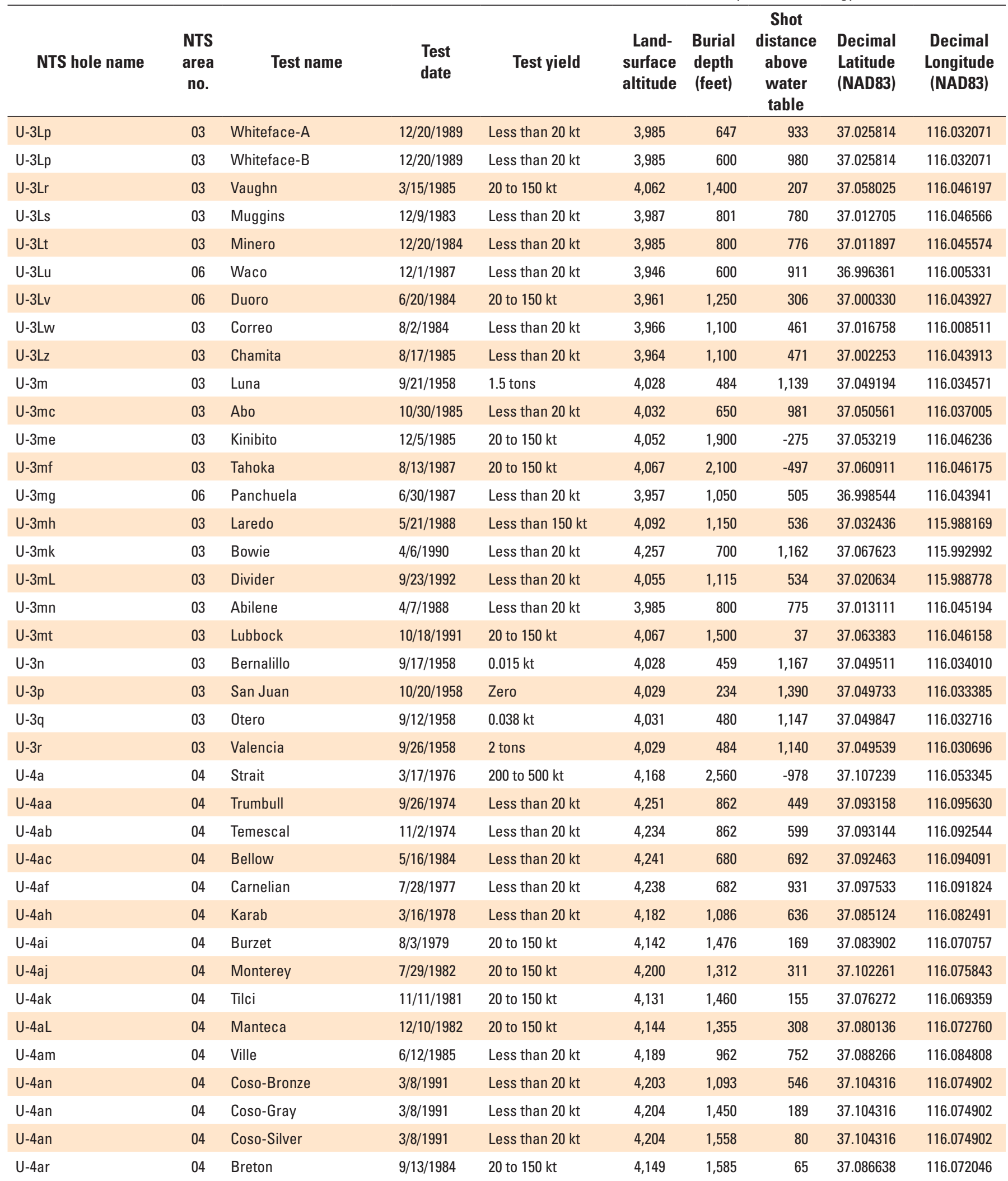


Appendix 2. Characteristics of underground nuclear detonations in Yucca Flat and vicinity, Nevada Test Site, 1951-1992 —Continued Land-surface altitude: Altitude in feet above sea level.

Shot distance above water table: Distance in feet. Negative values indicate distance below water table.

[NTS, Nevada Test Site; kt, kiloton; NAD83, North American Datum of 1983; NA, not available. Source of data: U.S. Department of Energy (2000)]

\begin{tabular}{|c|c|c|c|c|c|c|c|c|c|}
\hline NTS hole name & $\begin{array}{c}\text { NTS } \\
\text { area } \\
\text { no. }\end{array}$ & Test name & $\begin{array}{l}\text { Test } \\
\text { date }\end{array}$ & Test yield & $\begin{array}{l}\text { Land- } \\
\text { surface } \\
\text { altitude }\end{array}$ & $\begin{array}{l}\text { Burial } \\
\text { depth } \\
\text { (feet) }\end{array}$ & $\begin{array}{c}\text { Shot } \\
\text { distance } \\
\text { above } \\
\text { water } \\
\text { table }\end{array}$ & $\begin{array}{l}\text { Decimal } \\
\text { Latitude } \\
\text { (NAD83) }\end{array}$ & $\begin{array}{c}\text { Decimal } \\
\text { Longitude } \\
\text { (NAD83) }\end{array}$ \\
\hline U-4as & 04 & Roquefort & 10/16/1985 & 20 to $150 \mathrm{kt}$ & 4,488 & 1,362 & 303 & 37.109899 & 116.122254 \\
\hline U-4at & 04 & Palisade-1 & $5 / 15 / 1989$ & Less than $20 \mathrm{kt}$ & 4,479 & 1,100 & 508 & 37.107563 & 116.121756 \\
\hline U-4at & 04 & Palisade-3 & $5 / 15 / 1989$ & Less than $20 \mathrm{kt}$ & 4,479 & 1,325 & 284 & 37.107563 & 116.121756 \\
\hline U-4au & 04 & Bullfrog & $8 / 30 / 1988$ & Less than $150 \mathrm{kt}$ & 4,145 & 1,605 & 37 & 37.085883 & 116.069387 \\
\hline U-4av & 04 & Bristol & 11/26/1991 & Less than $20 \mathrm{kt}$ & 4,178 & 1,500 & 82 & 37.096438 & 116.070482 \\
\hline U-4b & 04 & Mackerel & 2/18/1964 & Less than $20 \mathrm{kt}$ & 4,145 & 1,095 & 493 & 37.095580 & 116.051592 \\
\hline U-4c & 04 & Zaza & 9/27/1967 & 20 to $200 \mathrm{kt}$ & 4,158 & 2,188 & -587 & 37.098719 & 116.054095 \\
\hline U-4g & 04 & Iceberg & $3 / 23 / 1978$ & 20 to $150 \mathrm{kt}$ & 4,152 & 2,100 & -509 & 37.101730 & 116.052017 \\
\hline U-4h & 04 & Scantling & 8/19/1977 & 20 to $150 \mathrm{kt}$ & 4,175 & 2,300 & -720 & 37.109986 & 116.055379 \\
\hline U-4i & 04 & Glencoe & 3/22/1986 & $29 \mathrm{kt}$ & 4,136 & 2,000 & -383 & 37.082958 & 116.066909 \\
\hline U-4j & 04 & Jornada & 1/28/1982 & $139 \mathrm{kt}$ & 4,134 & 2,100 & -530 & 37.091294 & 116.052103 \\
\hline U-4L & 04 & Quinella & 2/8/1979 & 20 to $150 \mathrm{kt}$ & 4,159 & 1,900 & -313 & 37.102436 & 116.055712 \\
\hline$U-4 n$ & 04 & Hearts & 9/6/1979 & $140 \mathrm{kt}$ & 4,130 & 2,100 & -549 & 37.088064 & 116.053653 \\
\hline U-40 & 04 & Techado & 9/22/1983 & Less than $150 \mathrm{kt}$ & 4,159 & 1,750 & -131 & 37.105564 & 116.050270 \\
\hline U-4p & 04 & Rousanne & $11 / 12 / 1981$ & 20 to $150 \mathrm{kt}$ & 4,166 & 1,700 & -61 & 37.108105 & 116.049848 \\
\hline U-6d & 06 & Presidio & 4/22/1987 & Less than $20 \mathrm{kt}$ & 3,932 & 1,050 & 453 & 36.983092 & 116.005447 \\
\hline U-6e & 06 & Austin & $6 / 21 / 1990$ & Less than $20 \mathrm{kt}$ & 3,942 & 1,150 & 354 & 36.992789 & 116.005364 \\
\hline U-6g & 06 & Harlingen-A & 8/23/1988 & Less than $20 \mathrm{kt}$ & 3,945 & 950 & 569 & 36.991133 & 116.018873 \\
\hline U-6h & 06 & Harlingen-B & 8/23/1988 & Less than $20 \mathrm{kt}$ & 3,943 & 950 & 566 & 36.988661 & 116.018889 \\
\hline U-6i & 06 & Monahans-B & 11/9/1988 & Less than $20 \mathrm{kt}$ & 3,942 & 950 & 566 & 36.988678 & 116.021970 \\
\hline U-7a & 07 & Forest & $10 / 31 / 1964$ & Less than $20 \mathrm{kt}$ & 4,255 & 1,269 & 574 & 37.107161 & 116.033111 \\
\hline U-7aa & 03 & Tajique & 6/28/1972 & Less than $20 \mathrm{kt}$ & 4,267 & 1,090 & 783 & 37.069545 & 115.992975 \\
\hline U-7ab & 07 & Redmud & 12/8/1976 & Less than $20 \mathrm{kt}$ & 4,251 & 1,400 & 350 & 37.079217 & 116.002487 \\
\hline U-7ac & 07 & Escabosa & $7 / 10 / 1974$ & 20 to $200 \mathrm{kt}$ & 4,102 & 2,100 & -411 & 37.074983 & 116.032691 \\
\hline U-7ad & 07 & Miera & $3 / 8 / 1973$ & 20 to $200 \mathrm{kt}$ & 4,286 & 1,866 & 14 & 37.103544 & 116.027599 \\
\hline U-7ae & 07 & Strake & 8/4/1977 & 20 to $150 \mathrm{kt}$ & 4,266 & 1,700 & 94 & 37.086523 & 116.007737 \\
\hline U-7af & 07 & Potrillo & 6/21/1973 & 20 to $200 \mathrm{kt}$ & 4,207 & 1,865 & -63 & 37.091989 & 116.028091 \\
\hline U-7ag & 07 & Obar & 4/30/1975 & 20 to $200 \mathrm{kt}$ & 4,286 & 1,867 & 13 & 37.108806 & 116.029666 \\
\hline
\end{tabular}


Appendix 2. Characteristics of underground nuclear detonations in Yucca Flat and vicinity, Nevada Test Site, 1951-1992—Continued Land-surface altitude: Altitude in feet above sea level.

Shot distance above water table: Distance in feet. Negative values indicate distance below water table.

[NTS, Nevada Test Site; kt, kiloton; NAD83, North American Datum of 1983; NA, not available. Source of data: U.S. Department of Energy (2000)]

\begin{tabular}{|c|c|c|c|c|c|c|c|c|c|}
\hline NTS hole name & $\begin{array}{c}\text { NTS } \\
\text { area } \\
\text { no. }\end{array}$ & Test name & $\begin{array}{l}\text { Test } \\
\text { date }\end{array}$ & Test yield & $\begin{array}{l}\text { Land- } \\
\text { surface } \\
\text { altitude }\end{array}$ & $\begin{array}{l}\text { Burial } \\
\text { depth } \\
\text { (feet) }\end{array}$ & $\begin{array}{c}\text { Shot } \\
\text { distance } \\
\text { above } \\
\text { water } \\
\text { table }\end{array}$ & $\begin{array}{l}\text { Decimal } \\
\text { Latitude } \\
\text { (NAD83) }\end{array}$ & $\begin{array}{c}\text { Decimal } \\
\text { Longitude } \\
\text { (NAD83) }\end{array}$ \\
\hline U-7ah & 07 & Mizzen & $6 / 3 / 1975$ & 20 to $200 \mathrm{kt}$ & 4,180 & 2,090 & -331 & 37.094783 & 116.036978 \\
\hline U-7ai & 03 & Keelson & 2/4/1976 & 20 to $200 \mathrm{kt}$ & 4,084 & 2,100 & -430 & 37.069208 & 116.031027 \\
\hline U-7ak & 07 & Esrom & 2/4/1976 & 20 to $200 \mathrm{kt}$ & 4,216 & 2,150 & -352 & 37.106547 & 116.038294 \\
\hline U-7aL & 07 & Draughts & 9/27/1978 & 20 to $150 \mathrm{kt}$ & 4,139 & 1,450 & 277 & 37.073819 & 116.020702 \\
\hline U-7am & 07 & Bulkhead & 4/27/1977 & 20 to $150 \mathrm{kt}$ & 4,219 & 1,950 & -141 & 37.094739 & 116.028752 \\
\hline U-7an & 07 & Billet & 7/27/1976 & 20 to $150 \mathrm{kt}$ & 4,099 & 2,085 & -491 & 37.075322 & 116.044686 \\
\hline U-7ao & 07 & Pineau & $7 / 16 / 1981$ & Less than $20 \mathrm{kt}$ & 4,220 & 670 & 1,131 & 37.088650 & 116.020238 \\
\hline U-7au & 07 & Rummy & 9/27/1978 & 20 to $150 \mathrm{kt}$ & 4,111 & 2,100 & -496 & 37.079755 & 116.052192 \\
\hline U-7av & 07 & Lowball & $7 / 12 / 1978$ & 20 to $150 \mathrm{kt}$ & 4,109 & 1,850 & -245 & 37.078619 & 116.044656 \\
\hline U-7ax & 07 & Baccarat & 1/24/1979 & Less than $20 \mathrm{kt}$ & 4,389 & 1,070 & 917 & 37.105364 & 116.012546 \\
\hline U-7ay & 07 & Topmast & $3 / 23 / 1978$ & Less than $20 \mathrm{kt}$ & 4,296 & 1,500 & 387 & 37.098814 & 116.020491 \\
\hline$U-7 b$ & 07 & Auk & 10/2/1964 & Less than $20 \mathrm{kt}$ & 4,203 & 1,484 & 250 & 37.077878 & 116.009357 \\
\hline U-7ba & 07 & Baseball & 1/15/1981 & 20 to $150 \mathrm{kt}$ & 4,129 & 1,850 & -346 & 37.087041 & 116.045619 \\
\hline U-7bd & 07 & Paliza & 10/1/1981 & 20 to $150 \mathrm{kt}$ & 4,224 & 1,550 & 201 & 37.081572 & 116.009621 \\
\hline U-7be & 07 & Pyramid & $4 / 16 / 1980$ & 20 to $150 \mathrm{kt}$ & 4,241 & 1,900 & -72 & 37.101072 & 116.031400 \\
\hline U-7bo & 07 & Mundo & $5 / 1 / 1984$ & 20 to $150 \mathrm{kt}$ & 4,328 & 1,860 & 67 & 37.106175 & 116.023249 \\
\hline U-7bp & 07 & Atrisco & 8/5/1982 & $138 \mathrm{kt}$ & 4,248 & 2,100 & -334 & 37.084159 & 116.007415 \\
\hline U-7br & 07 & Borrego & $9 / 29 / 1982$ & Less than $150 \mathrm{kt}$ & 4,137 & 1,850 & -230 & 37.091255 & 116.045756 \\
\hline U-7bs & 07 & Hermosa & $4 / 2 / 1985$ & 20 to $150 \mathrm{kt}$ & 4,192 & 2,100 & -318 & 37.094764 & 116.033211 \\
\hline U-7bu & 07 & Turquoise & 4/14/1983 & Less than $150 \mathrm{kt}$ & 4,088 & 1,749 & -174 & 37.072789 & 116.046825 \\
\hline U-7bv & 07 & Ponil & 9/27/1985 & Less than $20 \mathrm{kt}$ & 4,300 & 1,200 & 628 & 37.089761 & 116.002634 \\
\hline U-7by & 07 & Midland & $7 / 16 / 1987$ & 20 to $150 \mathrm{kt}$ & 4,300 & 1,600 & 297 & 37.103506 & 116.024222 \\
\hline U-7ca & 07 & Texarkana & 2/10/1989 & 20 to $150 \mathrm{kt}$ & 4,244 & 1,650 & 49 & 37.076736 & 116.001481 \\
\hline U-7cb & 07 & Floydada & 8/15/1991 & Less than $20 \mathrm{kt}$ & 4,287 & 1,650 & 137 & 37.087286 & 116.002656 \\
\hline U-7e & 07 & Piranha & $5 / 13 / 1966$ & 20 to $200 \mathrm{kt}$ & 4,146 & 1,800 & -73 & 37.086803 & 116.034311 \\
\hline U-7f & 07 & Bronze & $7 / 23 / 1965$ & 20 to $200 \mathrm{kt}$ & 4,213 & 1,742 & 55 & 37.097786 & 116.033872 \\
\hline U-7g & 07 & Charcoal & 9/10/1965 & 20 to $200 \mathrm{kt}$ & 4,172 & 1,494 & 254 & 37.077919 & 116.017582 \\
\hline U-7h & 07 & Cabresto & $5 / 24 / 1973$ & Less than $20 \mathrm{kt}$ & 4,118 & 649 & 1,053 & 37.078000 & 116.031638 \\
\hline
\end{tabular}


Appendix 2. Characteristics of underground nuclear detonations in Yucca Flat and vicinity, Nevada Test Site, 1951-1992 —Continued Land-surface altitude: Altitude in feet above sea level.

Shot distance above water table: Distance in feet. Negative values indicate distance below water table.

[NTS, Nevada Test Site; kt, kiloton; NAD83, North American Datum of 1983; NA, not available. Source of data: U.S. Department of Energy (2000)]

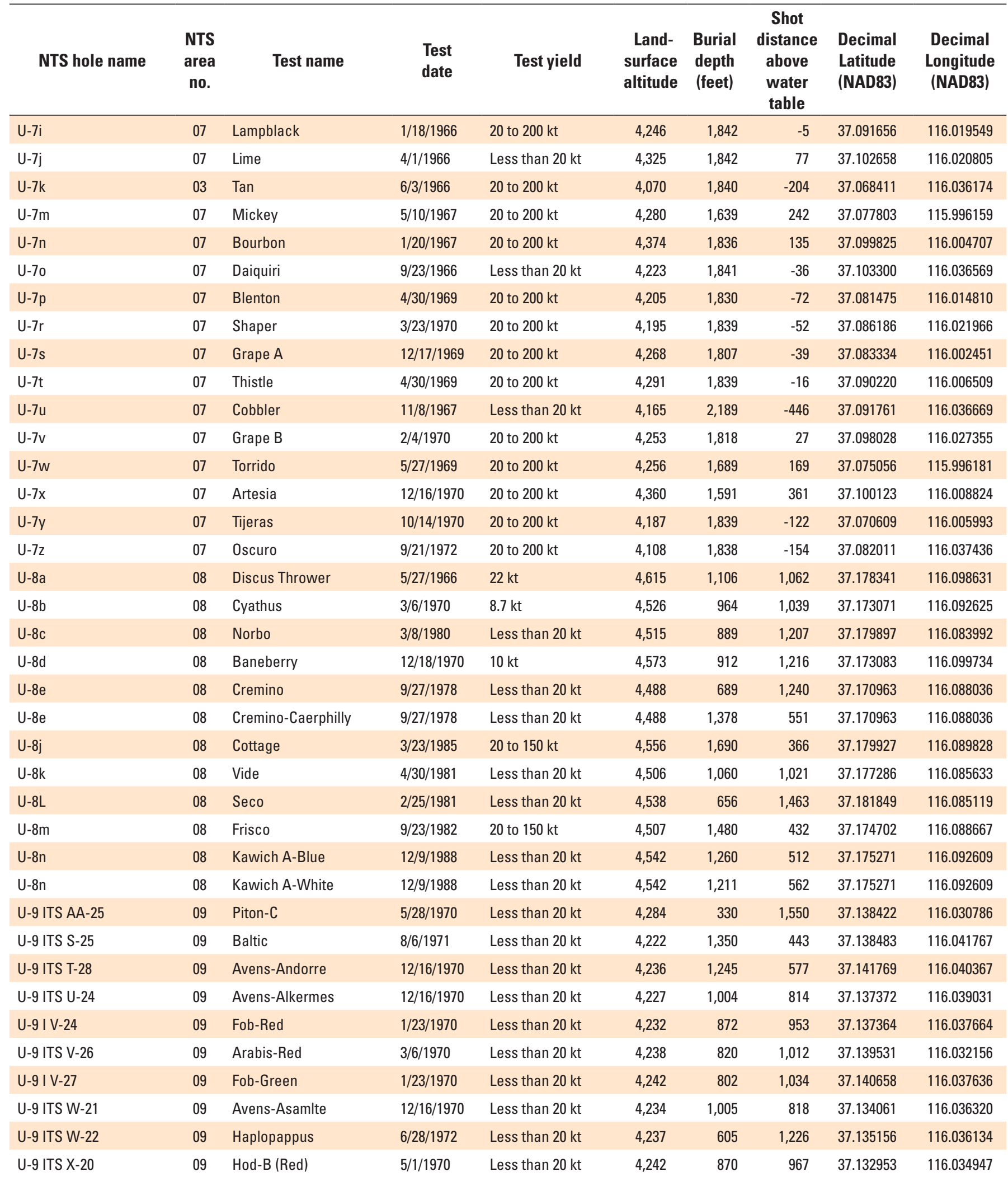


Appendix 2. Characteristics of underground nuclear detonations in Yucca Flat and vicinity, Nevada Test Site, 1951-1992 —Continued Land-surface altitude: Altitude in feet above sea level.

Shot distance above water table: Distance in feet. Negative values indicate distance below water table.

[NTS, Nevada Test Site; kt, kiloton; NAD83, North American Datum of 1983; NA, not available. Source of data: U.S. Department of Energy (2000)]

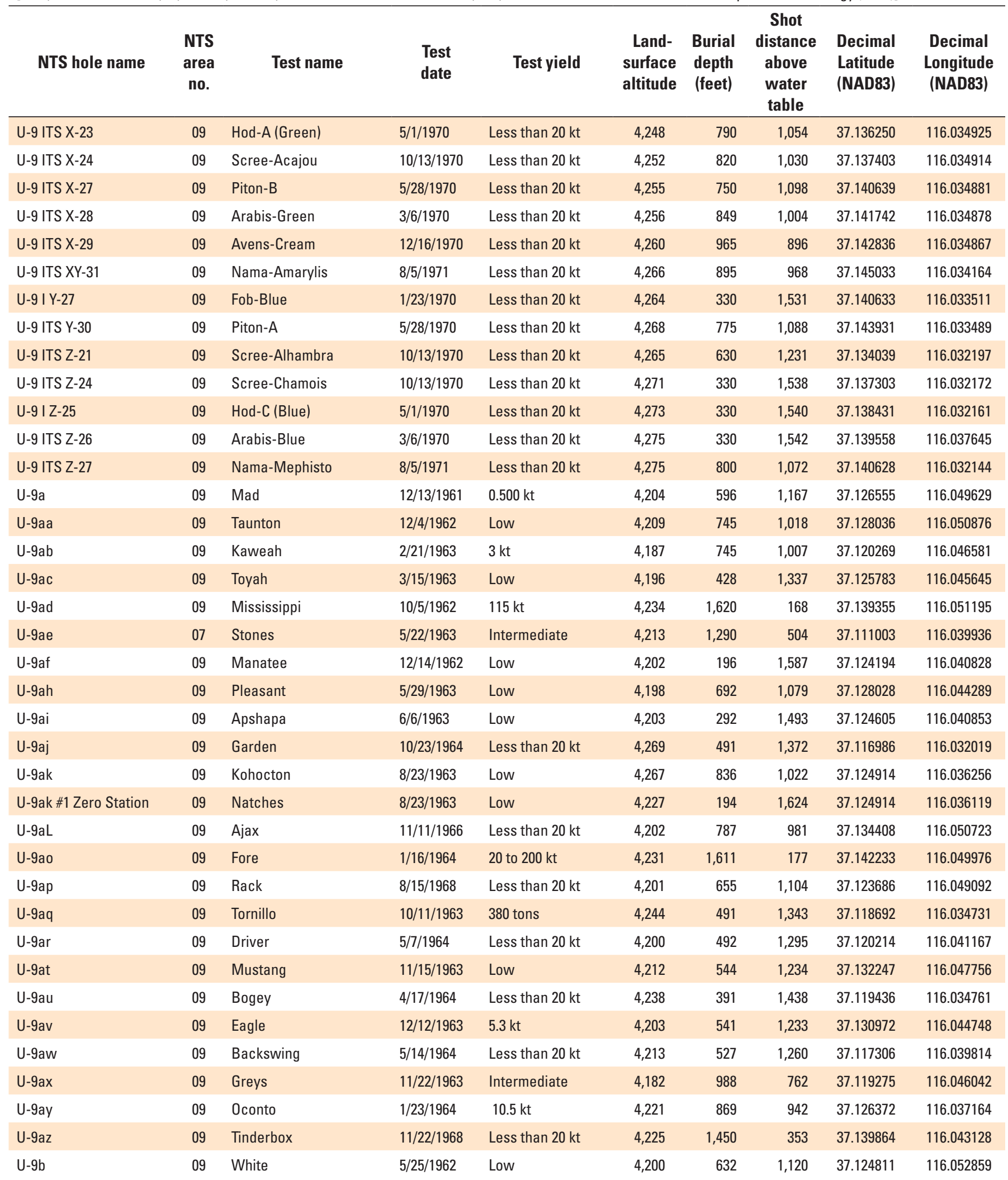


Appendix 2. Characteristics of underground nuclear detonations in Yucca Flat and vicinity, Nevada Test Site, 1951-1992 —Continued Land-surface altitude: Altitude in feet above sea level.

Shot distance above water table: Distance in feet. Negative values indicate distance below water table.

[NTS, Nevada Test Site; kt, kiloton; NAD83, North American Datum of 1983; NA, not available. Source of data: U.S. Department of Energy (2000)]

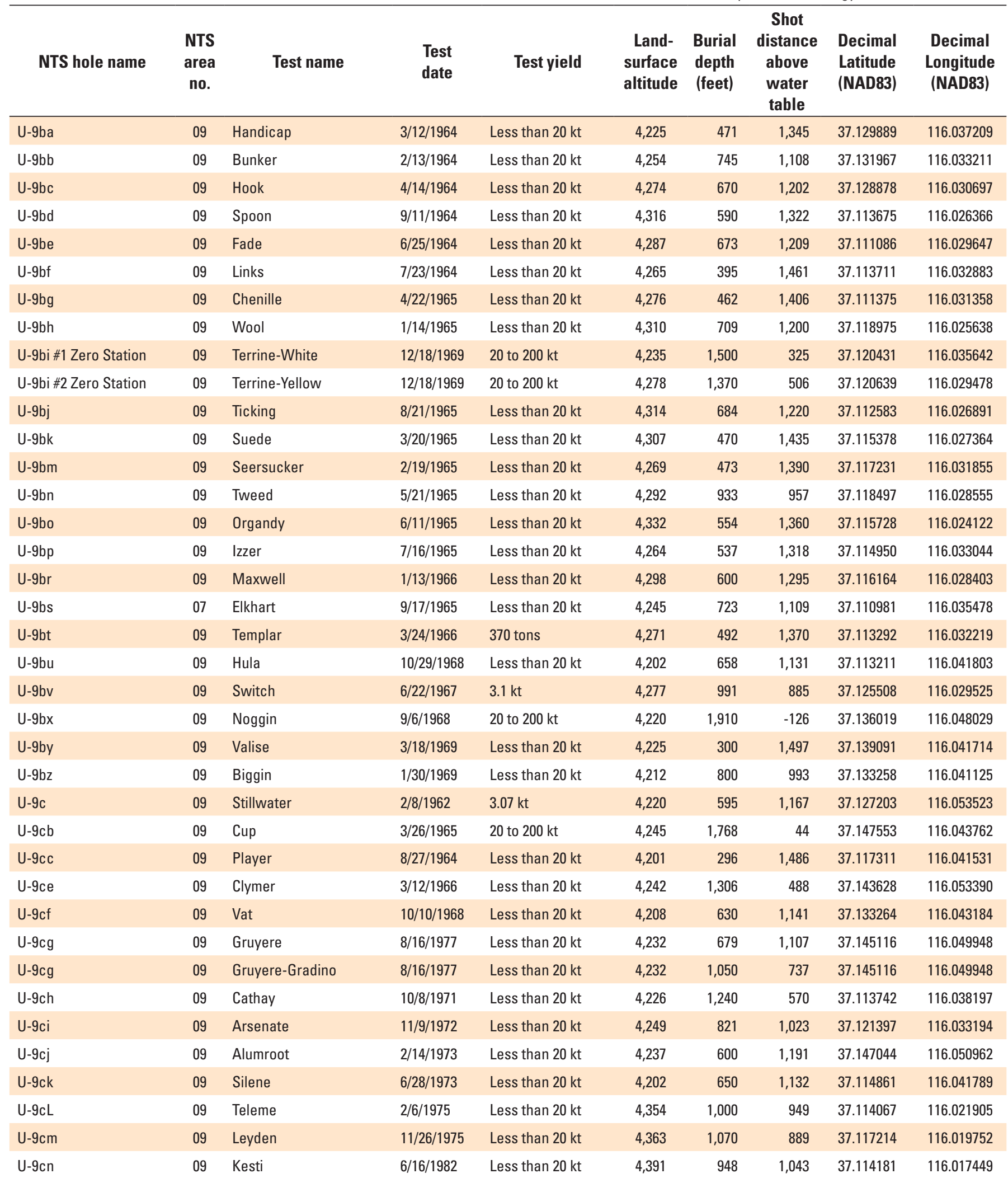


Appendix 2. Characteristics of underground nuclear detonations in Yucca Flat and vicinity, Nevada Test Site, 1951-1992—Continued Land-surface altitude: Altitude in feet above sea level.

Shot distance above water table: Distance in feet. Negative values indicate distance below water table.

[NTS, Nevada Test Site; kt, kiloton; NAD83, North American Datum of 1983; NA, not available. Source of data: U.S. Department of Energy (2000)]

\begin{tabular}{|c|c|c|c|c|c|c|c|c|c|}
\hline NTS hole name & $\begin{array}{c}\text { NTS } \\
\text { area } \\
\text { no. }\end{array}$ & Test name & $\begin{array}{l}\text { Test } \\
\text { date }\end{array}$ & Test yield & $\begin{array}{l}\text { Land- } \\
\text { surface } \\
\text { altitude }\end{array}$ & $\begin{array}{l}\text { Burial } \\
\text { depth } \\
\text { (feet) }\end{array}$ & $\begin{array}{c}\text { Shot } \\
\text { distance } \\
\text { above } \\
\text { water } \\
\text { table }\end{array}$ & $\begin{array}{l}\text { Decimal } \\
\text { Latitude } \\
\text { (NAD83) }\end{array}$ & $\begin{array}{l}\text { Decimal } \\
\text { Longitude } \\
\text { (NAD83) }\end{array}$ \\
\hline U-9cp & 09 & Campos & 2/13/1978 & Less than $20 \mathrm{kt}$ & 4,253 & 1,050 & 801 & 37.126069 & 116.032608 \\
\hline U-9cq & 09 & Dauphin & $11 / 14 / 1980$ & Less than $20 \mathrm{kt}$ & 4,372 & 1,050 & 919 & 37.111444 & 116.019527 \\
\hline U-9cs & 09 & Armada & 4/22/1983 & Less than $20 \mathrm{kt}$ & 4,339 & 869 & 1,067 & 37.111464 & 116.023299 \\
\hline U-9cv & 09 & Galena-Green & 6/23/1992 & Less than $20 \mathrm{kt}$ & 4,251 & 1,316 & 536 & 37.123872 & 116.032111 \\
\hline U-9cv & 09 & Galena-Orange & $6 / 23 / 1992$ & Less than $20 \mathrm{kt}$ & 4,251 & 1,250 & 601 & 37.123872 & 116.032111 \\
\hline U-9cv & 09 & Galena-Yellow & 6/23/1992 & Less than $20 \mathrm{kt}$ & 4,251 & 951 & 897 & 37.123872 & 116.032111 \\
\hline U-9cw & 09 & Cebrero & 8/14/1985 & Less than $20 \mathrm{kt}$ & 4,405 & 600 & 1,404 & 37.111033 & 116.015246 \\
\hline U-9g & 09 & Codsaw & $2 / 19 / 1962$ & Low & 4,217 & 696 & 1,108 & 37.127406 & 116.037989 \\
\hline U-9h & 09 & Cimarron & 2/23/1962 & $11.90 \mathrm{kt}$ & 4,208 & 1,000 & 770 & 37.128808 & 116.049179 \\
\hline U-9i & 09 & Anacostia & $11 / 27 / 1962$ & $5.2 \mathrm{kt}$ & 4,268 & 744 & 1,119 & 37.122761 & 116.029889 \\
\hline U-9j & 09 & Hoosic & $3 / 28 / 1962$ & $3.40 \mathrm{kt}$ & 4,235 & 613 & 1,214 & 37.124272 & 116.034747 \\
\hline U-9k & 09 & Dead & $4 / 21 / 1962$ & Low & 4,261 & 635 & 1,221 & 37.118958 & 116.032392 \\
\hline U-9L & 09 & Passaic & $4 / 6 / 1962$ & Low & 4,183 & 766 & 993 & 37.117628 & 116.044881 \\
\hline U-9m & 09 & Eel & $5 / 19 / 1962$ & $4.5 \mathrm{kt}$ & 4,200 & 714 & 1,046 & 37.122589 & 116.048078 \\
\hline U-9n & 09 & Hudson & 4/12/1962 & Low & 4,200 & 495 & 1,273 & 37.127130 & 116.045737 \\
\hline U-9w \#1 & 09 & Paisano & 4/24/1963 & Low & 4,225 & 187 & 1,623 & 37.120481 & 116.037044 \\
\hline U-9 ITS W-24.5 & 09 & Solanum & 12/14/1972 & Less than $20 \mathrm{kt}$ & 4,246 & 660 & 1,242 & 37.138036 & 116.035595 \\
\hline$U-9 x$ & 09 & Allegheny & $9 / 29 / 1962$ & Low & 4,258 & 692 & 1,157 & 37.116631 & 116.033647 \\
\hline U-9y & 09 & Wichita & $7 / 27 / 1962$ & Low & 4,239 & 493 & 1,301 & 37.129666 & 116.057354 \\
\hline U-9 ITS yz-26 & 09 & Canna-Limoges & 11/17/1972 & Less than $20 \mathrm{kt}$ & 4,265 & 700 & 1,162 & 37.139536 & 116.033233 \\
\hline U-9 ITS yz-26 & 09 & Canna-Umbrinus & 11/17/1972 & Less than $20 \mathrm{kt}$ & 4,265 & 600 & 1,262 & 37.139536 & 116.033233 \\
\hline U-9z & 09 & York & $8 / 24 / 1962$ & Low & 4,208 & 743 & 1,047 & 37.118589 & 116.040353 \\
\hline U-10a & 10 & Dub & $6 / 30 / 1964$ & $11.7 \mathrm{kt}$ & 4,293 & 850 & 1,037 & 37.174380 & 116.057266 \\
\hline U-10aа & 10 & Rivet I & 1/18/1967 & Less than $20 \mathrm{kt}$ & 4,273 & 498 & 1,361 & 37.165072 & 116.047418 \\
\hline U-10ab & 10 & Vito & $7 / 14 / 1967$ & Less than $20 \mathrm{kt}$ & 4,280 & 317 & 1,557 & 37.165200 & 116.045801 \\
\hline U-10ad & 10 & Vigil & $11 / 22 / 1966$ & Less than $20 \mathrm{kt}$ & 4,281 & 300 & 1,569 & 37.169336 & 116.049184 \\
\hline U-10af & 10 & Yard & 9/7/1967 & 20 to $200 \mathrm{kt}$ & 4,257 & 1,710 & 113 & 37.153111 & 116.053654 \\
\hline U-10ag & 10 & Worth & 10/25/1967 & Less than $20 \mathrm{kt}$ & 4,251 & 615 & 1,152 & 37.156291 & 116.049465 \\
\hline
\end{tabular}


Appendix 2. Characteristics of underground nuclear detonations in Yucca Flat and vicinity, Nevada Test Site, 1951-1992 —Continued Land-surface altitude: Altitude in feet above sea level.

Shot distance above water table: Distance in feet. Negative values indicate distance below water table.

[NTS, Nevada Test Site; kt, kiloton; NAD83, North American Datum of 1983; NA, not available. Source of data: U.S. Department of Energy (2000)]

\begin{tabular}{|c|c|c|c|c|c|c|c|c|c|}
\hline NTS hole name & $\begin{array}{c}\text { NTS } \\
\text { area } \\
\text { no. }\end{array}$ & Test name & $\begin{array}{l}\text { Test } \\
\text { date }\end{array}$ & Test yield & $\begin{array}{l}\text { Land- } \\
\text { surface } \\
\text { altitude }\end{array}$ & $\begin{array}{l}\text { Burial } \\
\text { depth } \\
\text { (feet) }\end{array}$ & $\begin{array}{c}\text { Shot } \\
\text { distance } \\
\text { above } \\
\text { water } \\
\text { table }\end{array}$ & $\begin{array}{l}\text { Decimal } \\
\text { Latitude } \\
\text { (NAD83) }\end{array}$ & $\begin{array}{c}\text { Decimal } \\
\text { Longitude } \\
\text { (NAD83) }\end{array}$ \\
\hline U-10ah & 10 & Staccato & 1/19/1968 & 20 to $200 \mathrm{kt}$ & 4,261 & 1,455 & 379 & 37.156339 & 116.054751 \\
\hline U-10ai & 10 & Polka & 12/6/1967 & Less than $20 \mathrm{kt}$ & 4,263 & 625 & 1,191 & 37.159219 & 116.053821 \\
\hline U-10aj B & 10 & Tub-B & 6/6/1968 & Less than $20 \mathrm{kt}$ & 4,285 & 620 & 1,261 & 37.165358 & 116.044309 \\
\hline U-10aj C & 10 & Tub-A & $6 / 6 / 1968$ & Less than $20 \mathrm{kt}$ & 4,294 & 620 & 1,268 & 37.167433 & 116.043359 \\
\hline U-10aj D & 10 & Tub-D & 6/6/1968 & Less than $20 \mathrm{kt}$ & 4,282 & 896 & 981 & 37.166936 & 116.045676 \\
\hline U-10aj F & 10 & Tub-C & 6/6/1968 & Less than $20 \mathrm{kt}$ & 4,298 & 620 & 1,272 & 37.165347 & 116.041551 \\
\hline U-10ak & 10 & Crock & $5 / 8 / 1968$ & Less than $20 \mathrm{kt}$ & 4,317 & 596 & 1,317 & 37.157275 & 116.035787 \\
\hline U-10am \#4 Zero Station & 08 & Tun-D & 12/10/1969 & Less than $20 \mathrm{kt}$ & 4,420 & 841 & 1,159 & 37.169427 & 116.077891 \\
\hline U-10an & 10 & Labis & 2/5/1970 & $25 \mathrm{kt}$ & 4,308 & 1,450 & 452 & 37.163914 & 116.039701 \\
\hline U-10ap \#1 & 10 & Cornice-Yellow & $5 / 15 / 1970$ & 20 to $200 \mathrm{kt}$ & 4,329 & 1,280 & 636 & 37.165881 & 116.036359 \\
\hline U-10ap \#3 & 10 & Cornice-Green & $5 / 15 / 1970$ & 20 to $200 \mathrm{kt}$ & 4,306 & 1,455 & 447 & 37.161872 & 116.039723 \\
\hline U-10aq & 10 & Bracken & 7/9/1971 & Less than $20 \mathrm{kt}$ & 4,342 & 1,000 & 920 & 37.164403 & 116.033603 \\
\hline U-10ar & 10 & Lagoon & 10/14/1971 & Less than $20 \mathrm{kt}$ & 4,307 & 1,000 & 887 & 37.179733 & 116.053960 \\
\hline U-10as & 10 & Pinedrops-Bayou & $1 / 10 / 1974$ & Less than $20 \mathrm{kt}$ & 4,298 & 1,125 & 764 & 37.174078 & 116.051668 \\
\hline U-10as & 10 & Pinedrops-Sloat & $1 / 10 / 1974$ & Less than $20 \mathrm{kt}$ & 4,298 & 700 & 1,189 & 37.174078 & 116.051668 \\
\hline U-10b & 08 & Handcar & $11 / 5 / 1964$ & $12 \mathrm{kt}$ & 4,375 & 1,323 & 641 & 37.174324 & 116.067902 \\
\hline U-10ba & 10 & Dofino & 3/8/1977 & Less than $20 \mathrm{kt}$ & 4,296 & 600 & 1,285 & 37.176147 & 116.053826 \\
\hline U-10ba & 10 & Dofino-Lawton & 3/8/1977 & Less than $20 \mathrm{kt}$ & 4,296 & 925 & 959 & 37.176147 & 116.053826 \\
\hline U-10bb & 10 & Portola & $2 / 6 / 1975$ & Less than $20 \mathrm{kt}$ & 4,305 & 650 & 1,236 & 37.178361 & 116.052424 \\
\hline U-10bb & 10 & Portola-Larkin & 2/6/1975 & Less than $20 \mathrm{kt}$ & 4,305 & 900 & 986 & 37.178361 & 116.052424 \\
\hline U-10bc & 10 & Asco & 4/25/1978 & Less than $20 \mathrm{kt}$ & 4,305 & 600 & 1,301 & 37.154517 & 116.035631 \\
\hline U-10bd & 10 & Pera & 9/8/1979 & Less than $20 \mathrm{kt}$ & 4,289 & 656 & 1,229 & 37.154947 & 116.039059 \\
\hline U-10be & 08 & Orkney & $5 / 2 / 1984$ & Less than $20 \mathrm{kt}$ & 4,522 & 689 & 1,299 & 37.198428 & 116.054835 \\
\hline U-10bf & 10 & Queso & 8/11/1982 & Less than $20 \mathrm{kt}$ & 4,387 & 709 & 1,163 & 37.189744 & 116.048554 \\
\hline U-10bg & 10 & Havarti & 8/5/1981 & Less than $20 \mathrm{kt}$ & 4,298 & 656 & 1,239 & 37.153694 & 116.035945 \\
\hline U-10bh & 10 & $\begin{array}{l}\text { Hazebrook-Apricot } \\
\text { (Orange) }\end{array}$ & 2/3/1987 & Less than $20 \mathrm{kt}$ & 4,322 & 860 & 1,012 & 37.181094 & 116.049313 \\
\hline U-10bh & 10 & $\begin{array}{l}\text { Hazebrook-Checker- } \\
\text { berry (Red) }\end{array}$ & 2/3/1987 & Less than $20 \mathrm{kt}$ & 4,322 & 741 & 1,132 & 37.181094 & 116.049313 \\
\hline
\end{tabular}


Appendix 2. Characteristics of underground nuclear detonations in Yucca Flat and vicinity, Nevada Test Site, 1951-1992—Continued Land-surface altitude: Altitude in feet above sea level.

Shot distance above water table: Distance in feet. Negative values indicate distance below water table.

[NTS, Nevada Test Site; kt, kiloton; NAD83, North American Datum of 1983; NA, not available. Source of data: U.S. Department of Energy (2000)]

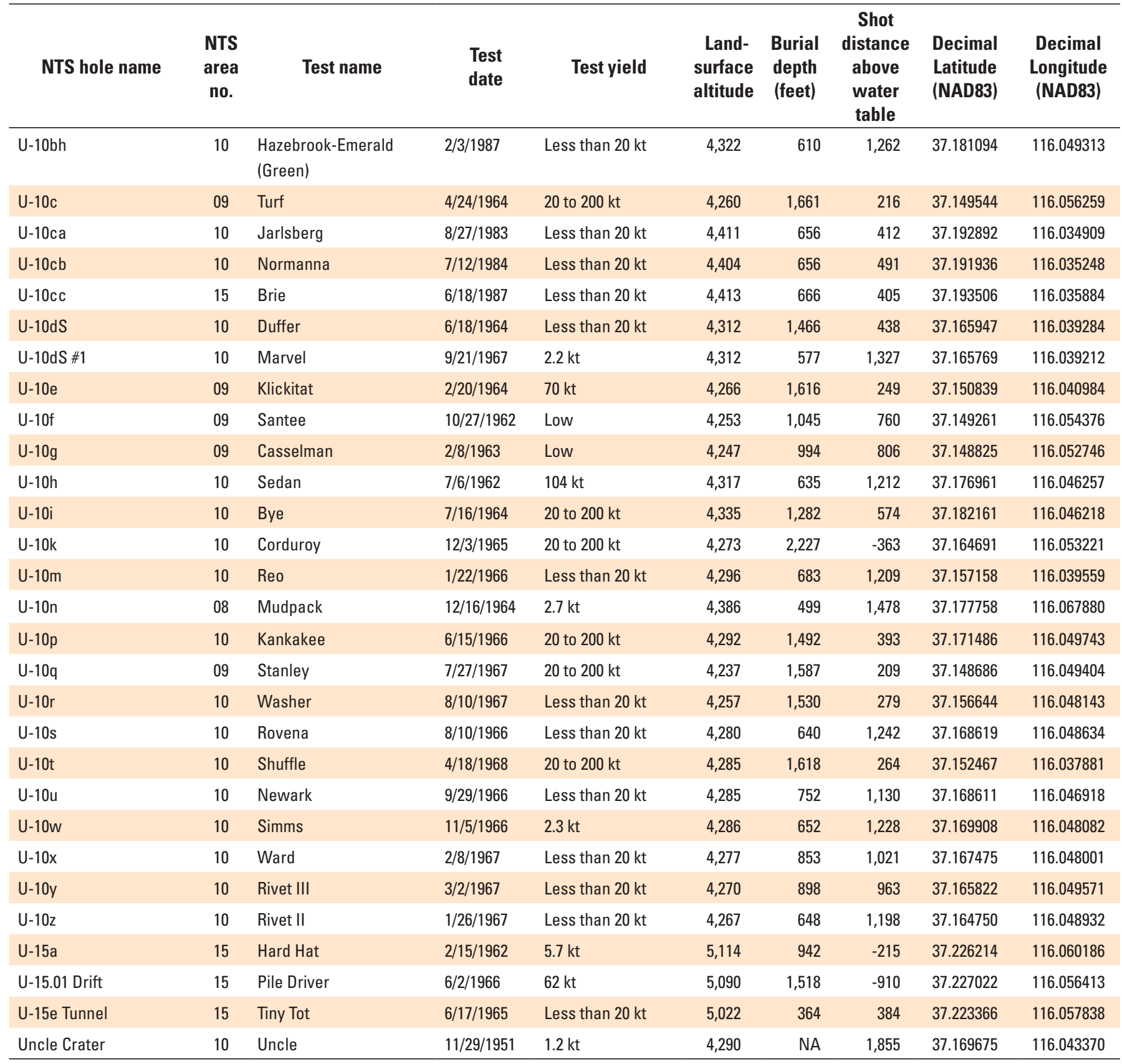




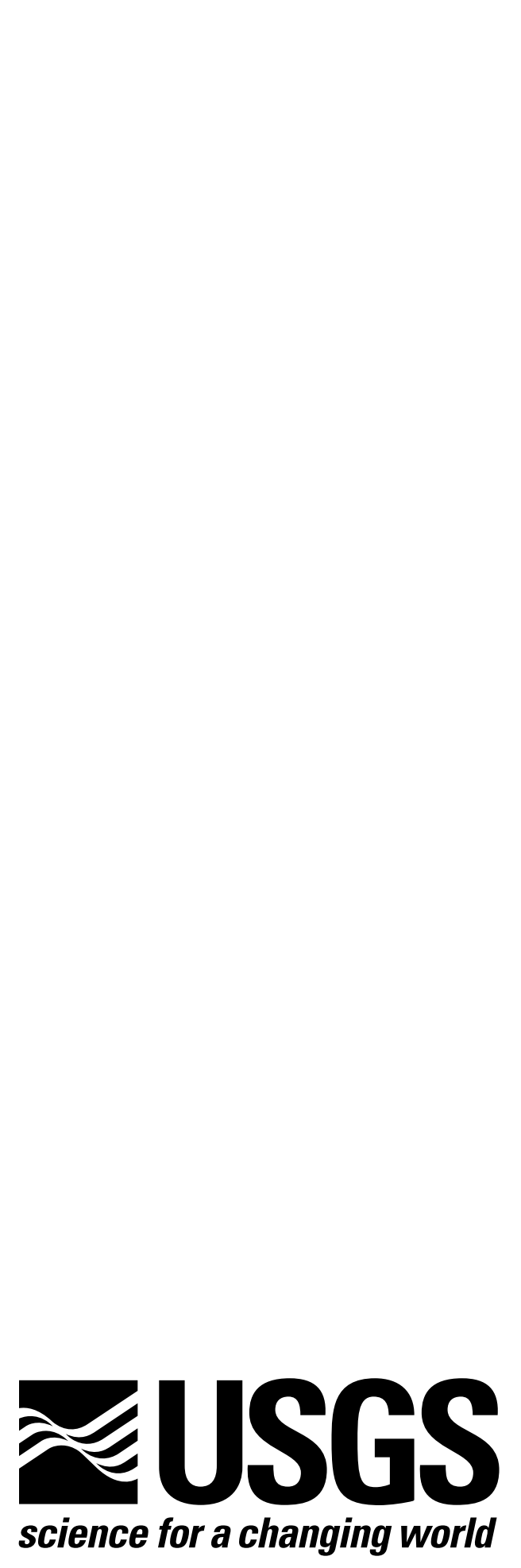
who manage, develop, and protect our Nation's water, energy, mineral, land, and biological resources. We help find natural resources, and we supply scientific understanding needed to help minimize or mitigate the effects of natural hazards and the environmental damage caused by human activities. The results of our efforts touch the daily lives of almost everyone. 